\title{
Photoinduced $6 \pi$-electrocyclization of a 1,3,5-hexatriene system containing an allomaltol fragment
}

Andrey N. Komogortsev*, Boris V. Lichitsky, Valeriya G. Melekhina, Darina I. Nasyrova and Constantine V. Milyutin

N.D. Zelinsky Institute of Organic Chemistry, Russian Academy of Science, Leninsky Pr., 47, Moscow 119991, Russian Federation 
Table of contents

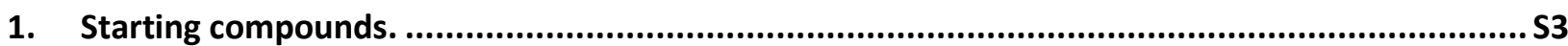

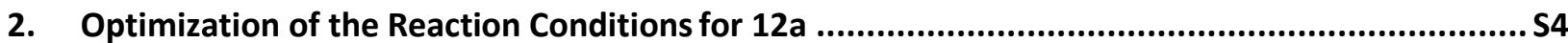

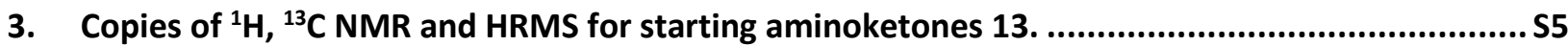

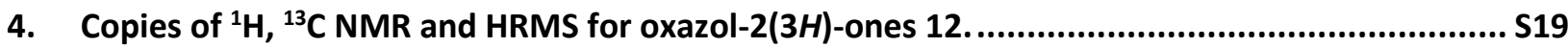

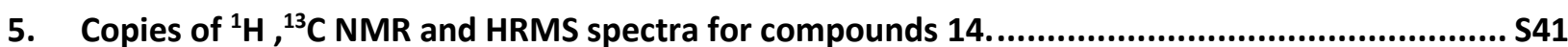

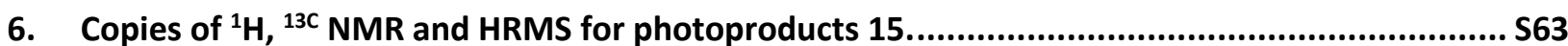

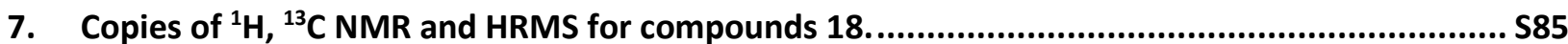

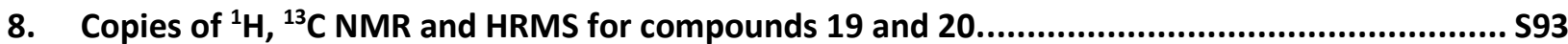

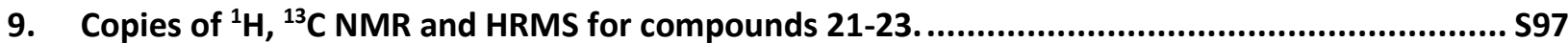

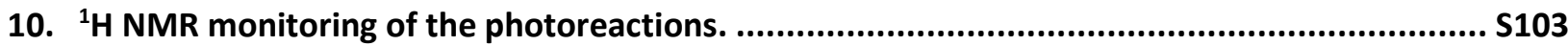

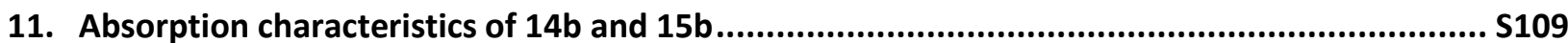

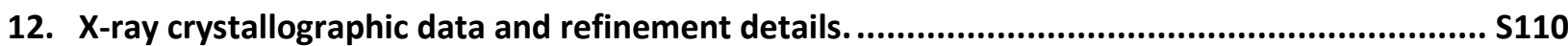

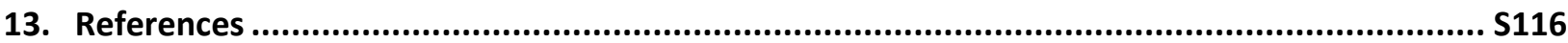


1. Starting compounds.

All synthesized $\alpha$-aminoketones 13 .<smiles>Cc1ccc(C(=O)C(NCCc2ccccc2)c2oc(C)cc(=O)c2O)cc1</smiles><smiles>COc1ccc(C(=O)C(NCc2ccc(C)cc2)c2oc(C)cc(=O)c2O)cc1</smiles><smiles>COc1ccc(C(=O)C(NCCc2ccccc2)c2oc(C)cc(=O)c2O)cc1</smiles><smiles>COc1ccc(C(=O)C(NCc2ccc(Cl)cc2)c2oc(C)cc(=O)c2O)cc1</smiles><smiles>COc1ccc(C(=O)C(NCCNC(C)=O)c2oc(C)cc(=O)c2O)cc1</smiles><smiles>COCCCNC(C(=O)c1ccc(OC)cc1)c1oc(C)cc(=O)c1O</smiles><smiles>Cc1cc(=O)c(O)c(C(NCCc2ccccc2)C(=O)c2ccccc2)o1</smiles><smiles>Cc1ccc(CNC(C(=O)c2ccccc2)c2oc(C)cc(=O)c2O)cc1</smiles><smiles>Cc1cc(=O)c(O)c(C(NCCc2ccccc2)C(=O)c2ccc(Cl)cc2)o1</smiles>

$13 i^{\mathrm{a}}$<smiles>Cc1cc(=O)c(O)c(C(NCc2ccccc2)C(=O)c2ccc(Cl)cc2)o1</smiles>

$13 \mathrm{j}^{\mathrm{b}}$<smiles>COc1ccc(C(=O)C(NCc2cccs2)c2oc(C)cc(=O)c2O)cc1</smiles>

$13 k^{a}$

${ }^{a}$ new compounds

${ }^{\mathrm{b}}$ previously synthesized compounds ${ }^{1}$ 


\section{Optimization of the Reaction Conditions for $12 a$}

Table S1. Optimization of the Reaction Conditions ${ }^{\mathrm{a}}$

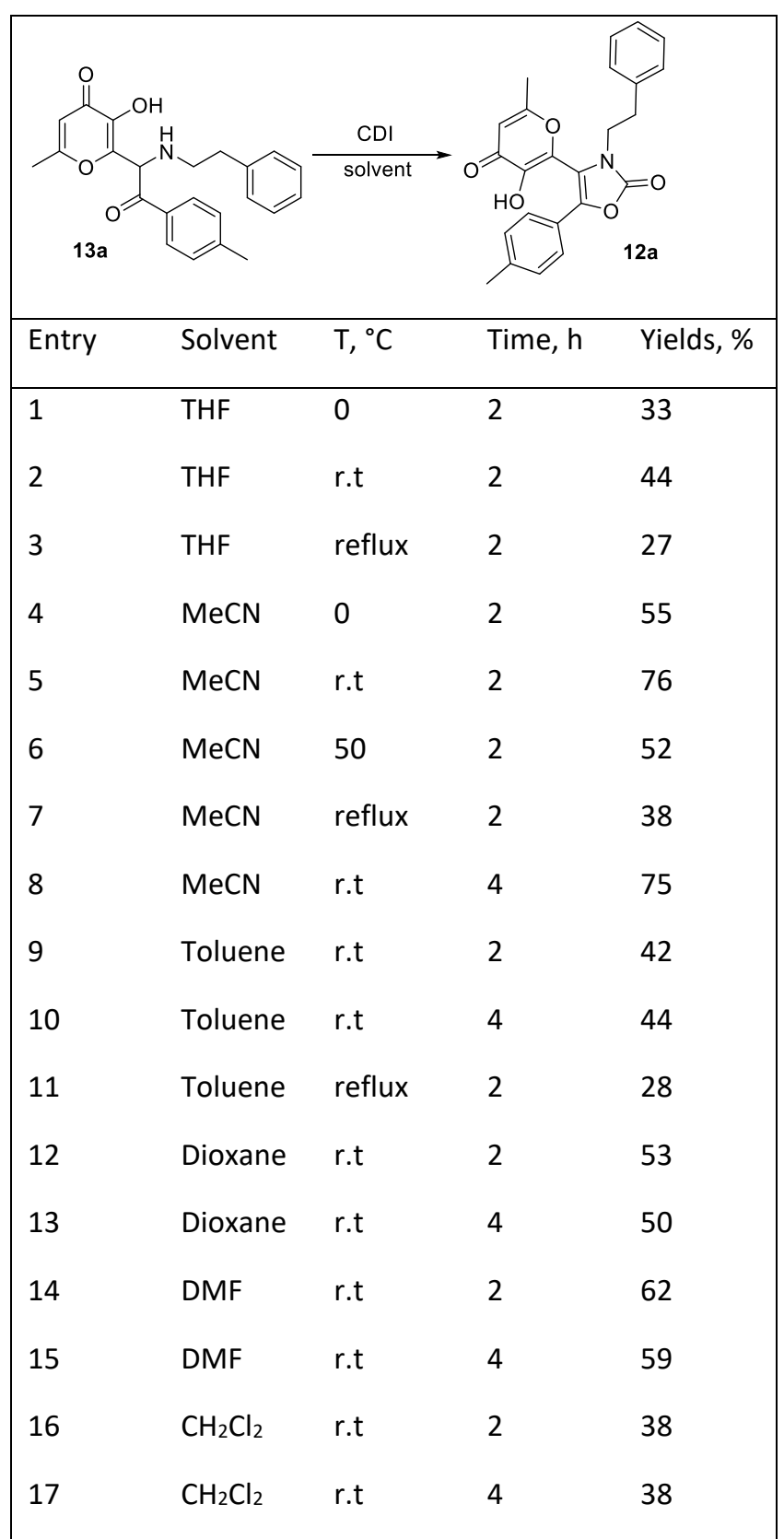

aReaction conditions: $13 \mathrm{a}$ ( $3 \mathrm{mmol}, 1.13 \mathrm{~g}), \mathrm{CDI}(4.5 \mathrm{mmol}, 0.73 \mathrm{~g})$, solvent, time, temperature. AcOH (10 $\mathrm{mmol}, 0.6 \mathrm{~g})$, poured into water $(50 \mathrm{ml})$, recrystallized $(\mathrm{EtOH}, 5 \mathrm{ml})$. 
3. Copies of ${ }^{1} \mathrm{H},{ }^{13} \mathrm{C}$ NMR and HRMS for starting aminoketones 13.

${ }^{1} \mathrm{H}$ NMR spectrum $\left(500 \mathrm{MHz}\right.$ ) of $13 \mathrm{a}$ in DMSO- $d_{6}$

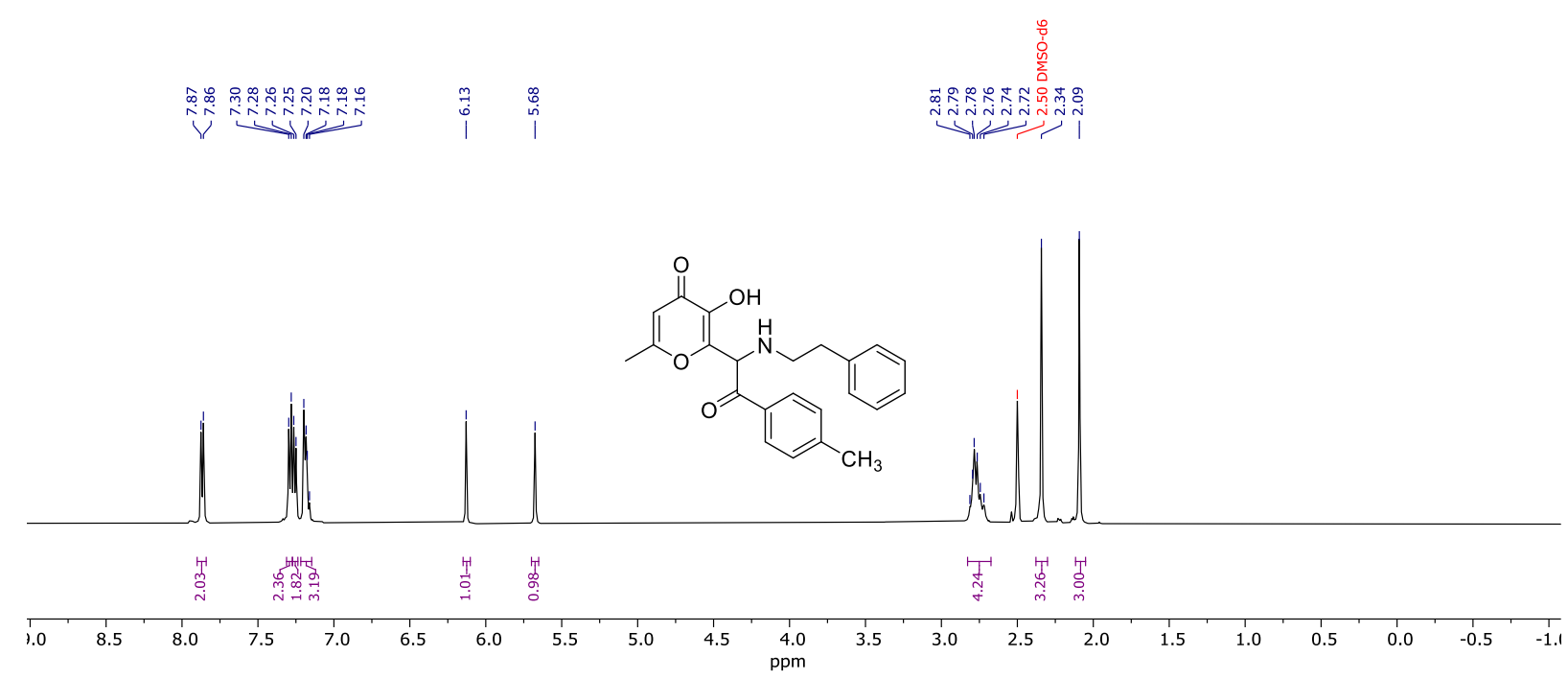

${ }^{13} \mathrm{C}\left\{{ }^{1} \mathrm{H}\right\}$ NMR spectrum (126 MHz) of 13a in DMSO- $d_{6}$
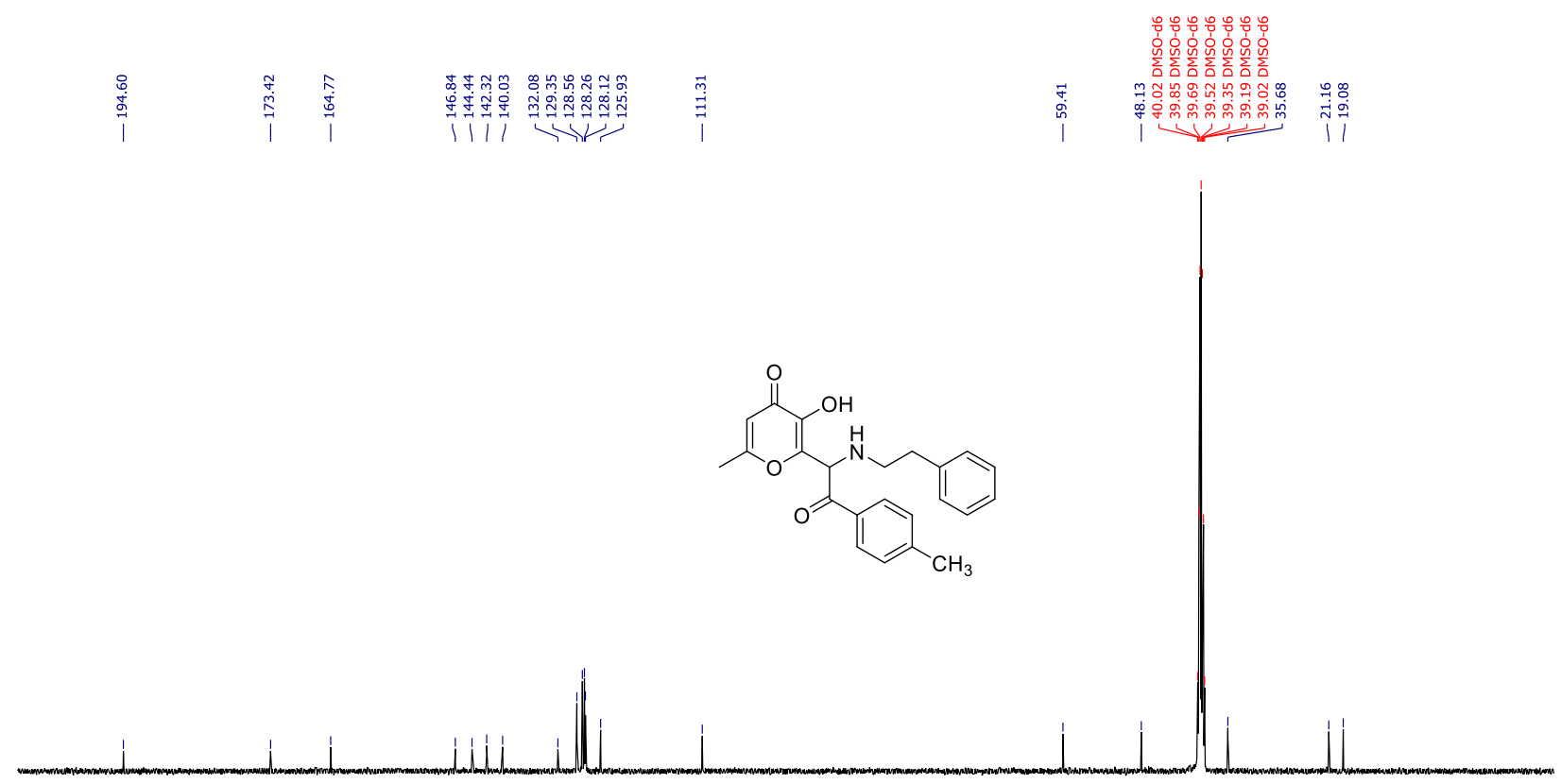

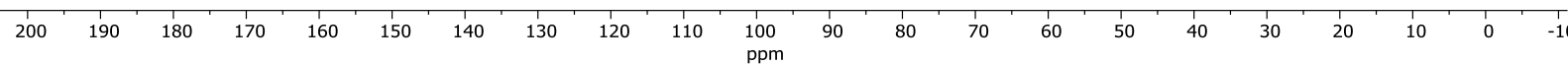


HRMS for compound 13a

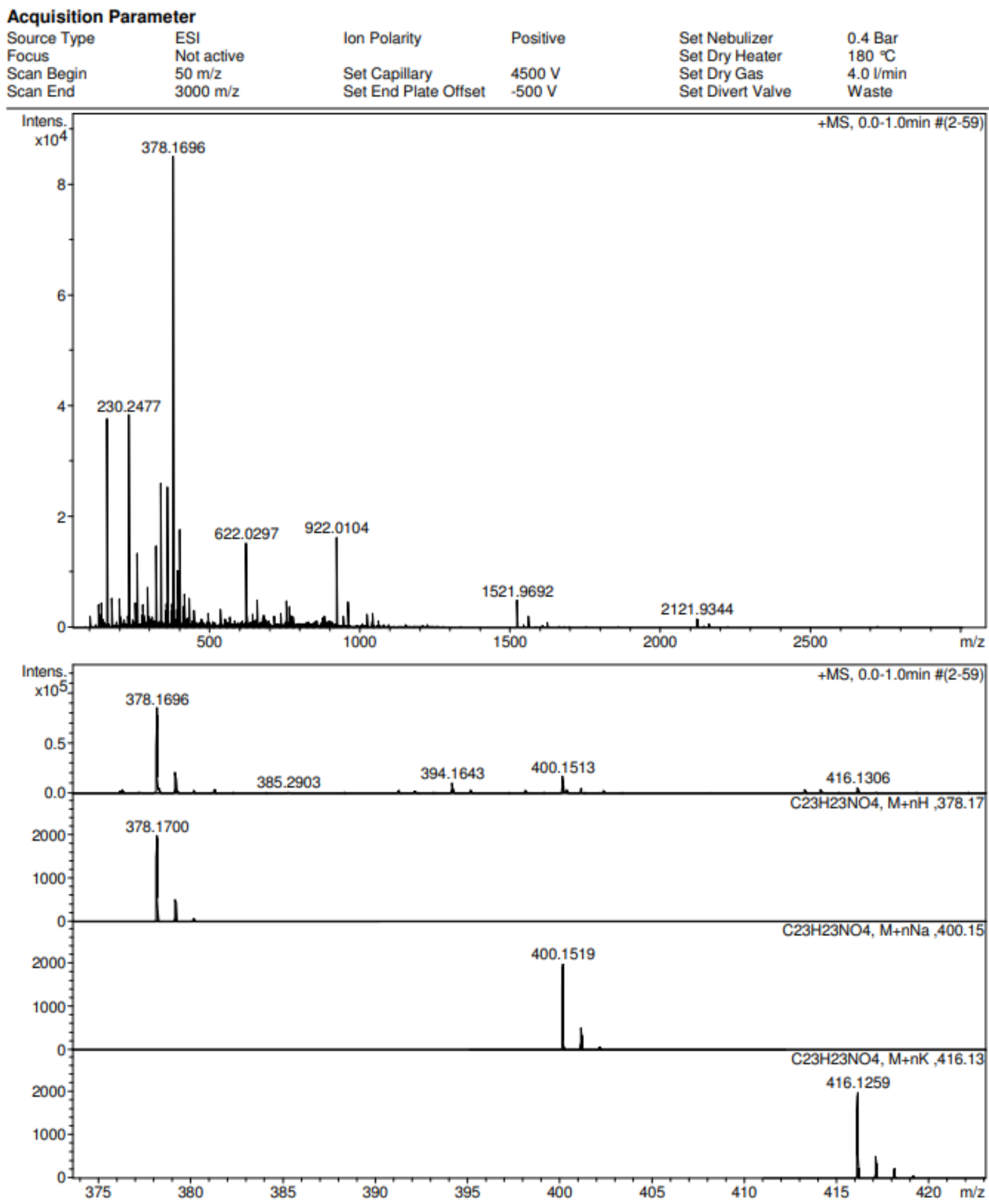


${ }^{1} \mathrm{H}$ NMR spectrum $(500 \mathrm{MHz})$ of $13 \mathbf{b}$ in DMSO- $d_{6}$

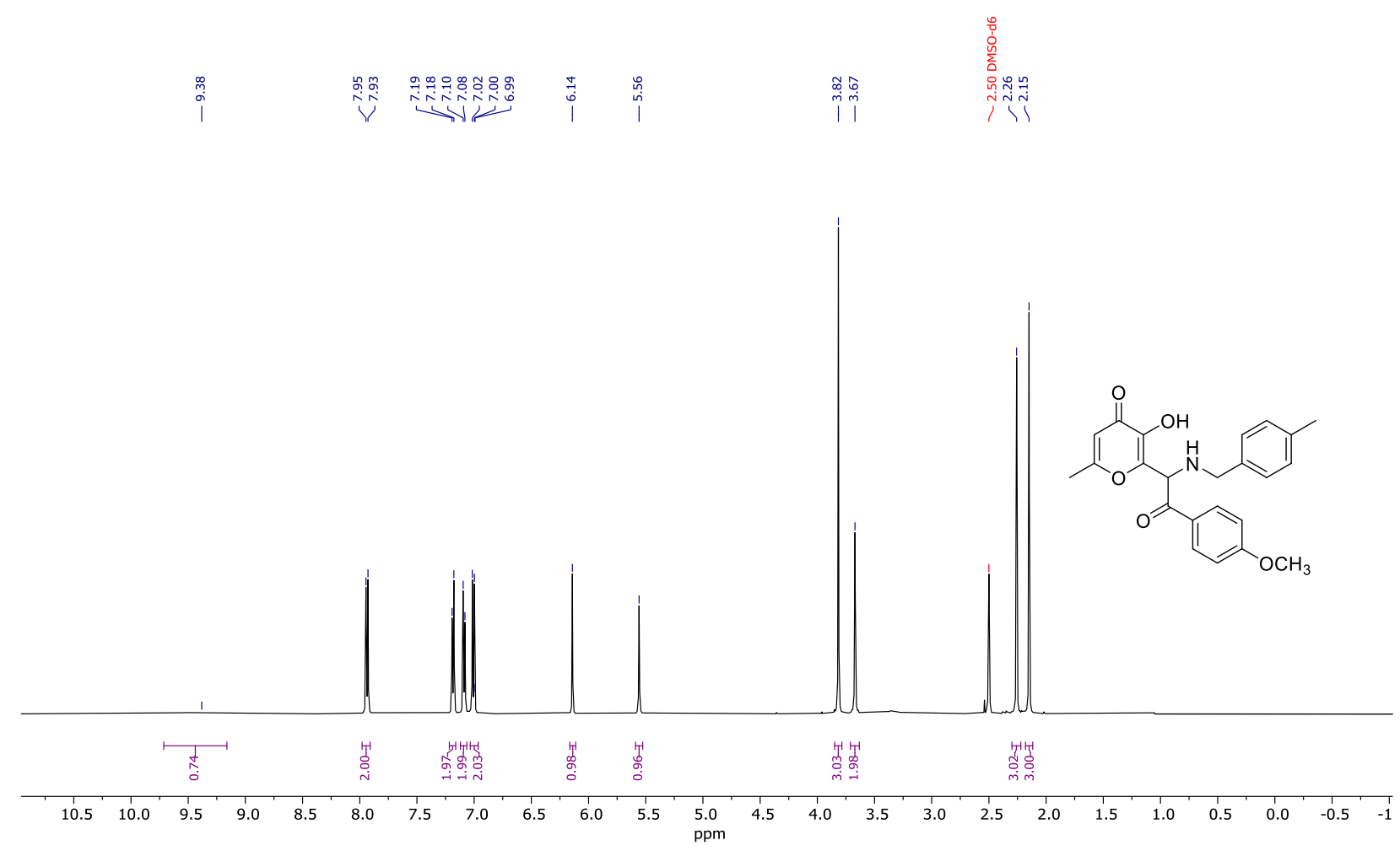

${ }^{13} \mathrm{C}\left\{{ }^{1} \mathrm{H}\right\}$ NMR spectrum (126 MHz) of $13 \mathbf{b}$ in DMSO- $d_{6}$

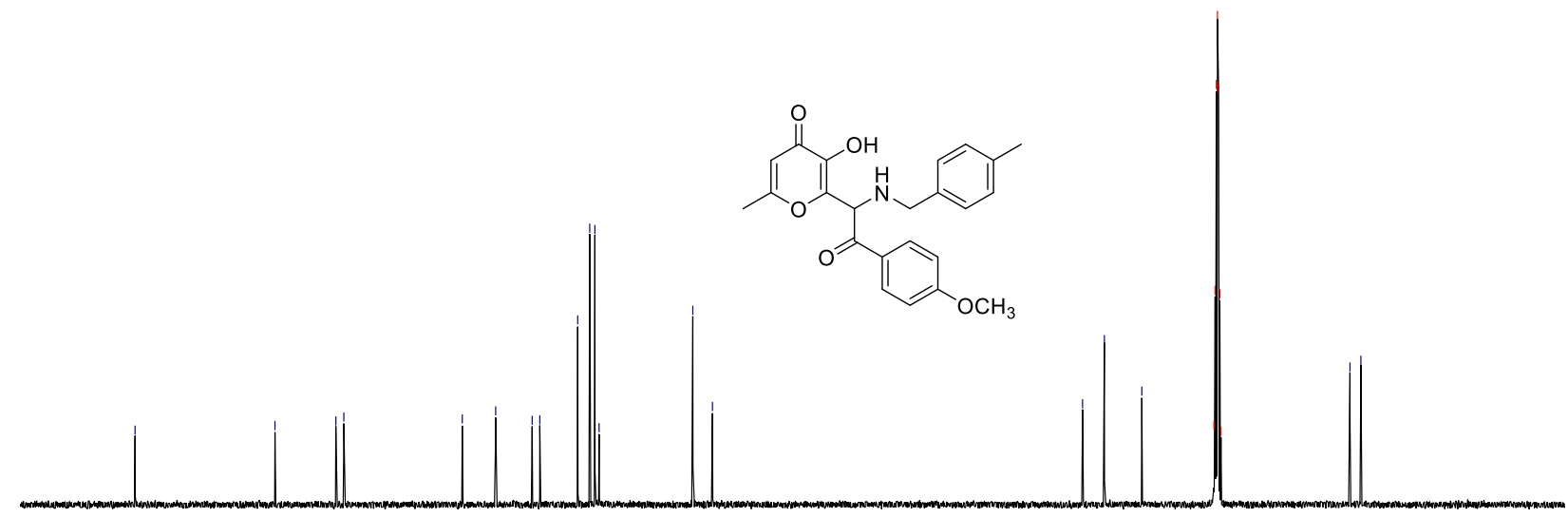

$\begin{array}{lllllllllll}200 & 190 & 180 & 170 & 160 & 150 & 140 & 130 & 120 & 110 & 100\end{array}$

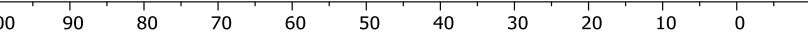


HRMS for compound $\mathbf{1 3 b}$

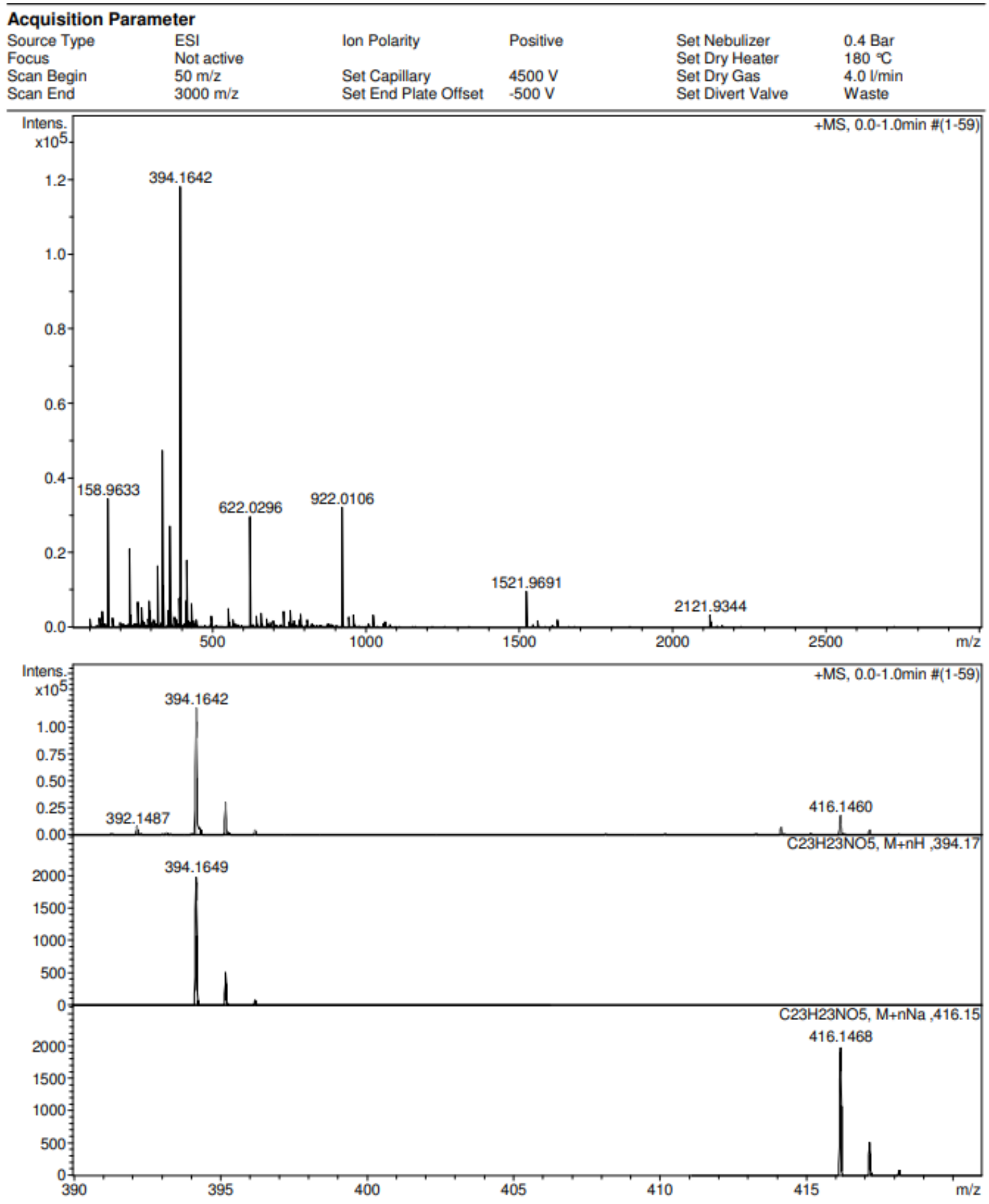


${ }^{1} \mathrm{H}$ NMR spectrum $(500 \mathrm{MHz})$ of $13 \mathrm{c}$ in DMSO- $d_{6}$

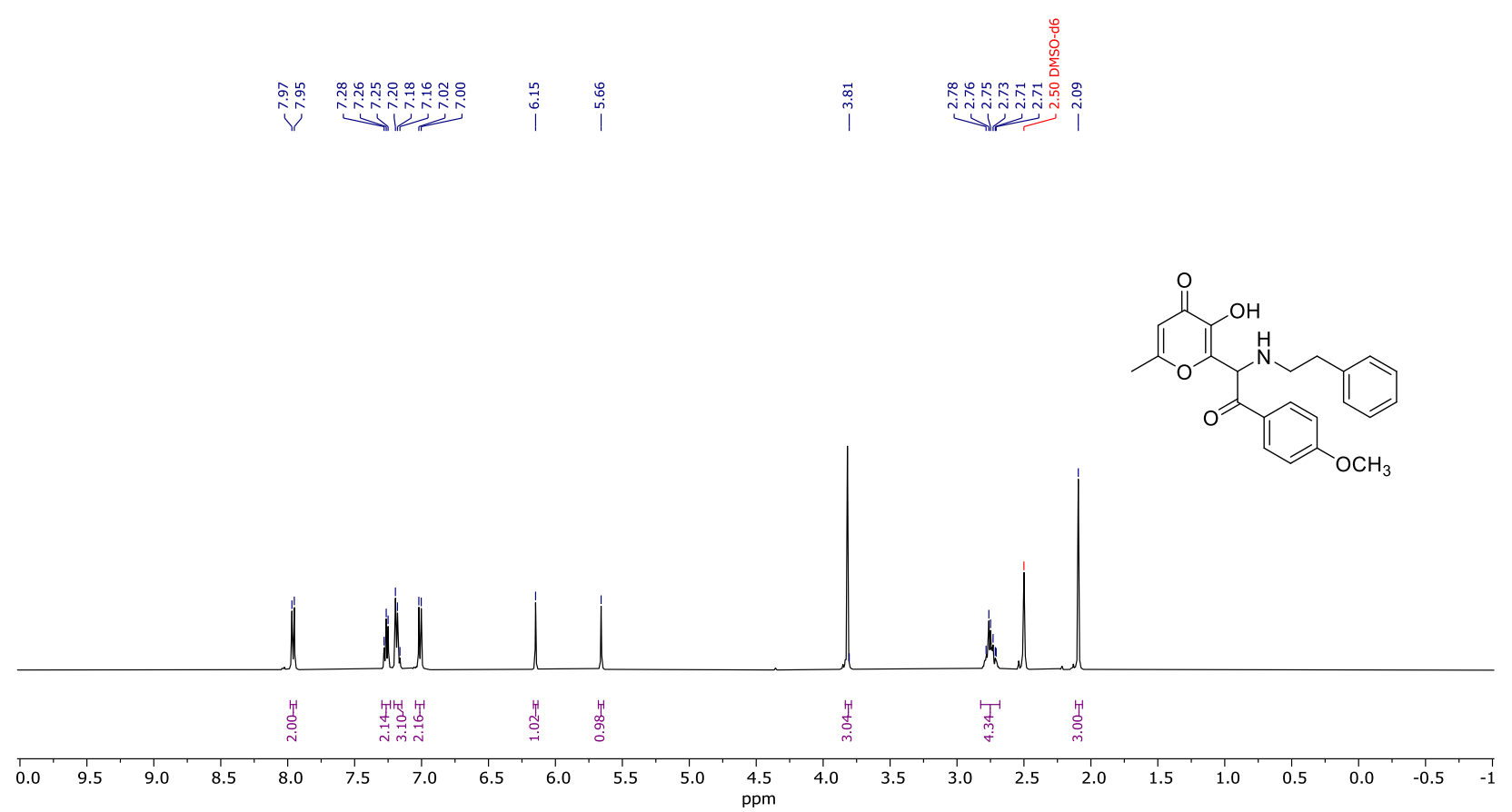

${ }^{13} \mathrm{C}\left\{{ }^{1} \mathrm{H}\right\}$ NMR spectrum $(126 \mathrm{MHz})$ of $13 \mathrm{c}$ in DMSO- $d_{6}$

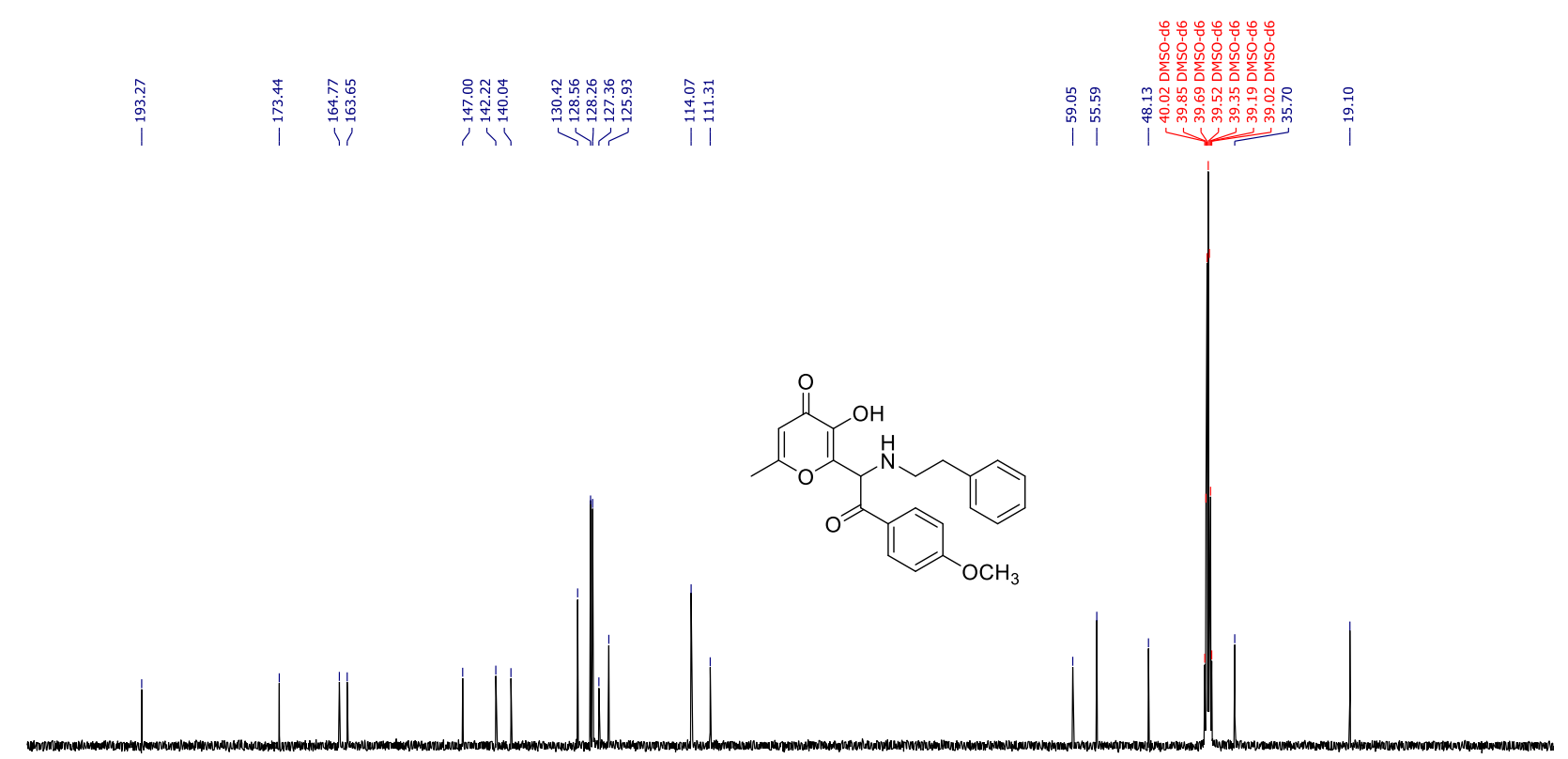

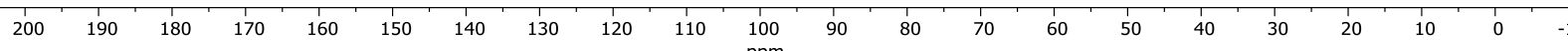


HRMS for compound 13c
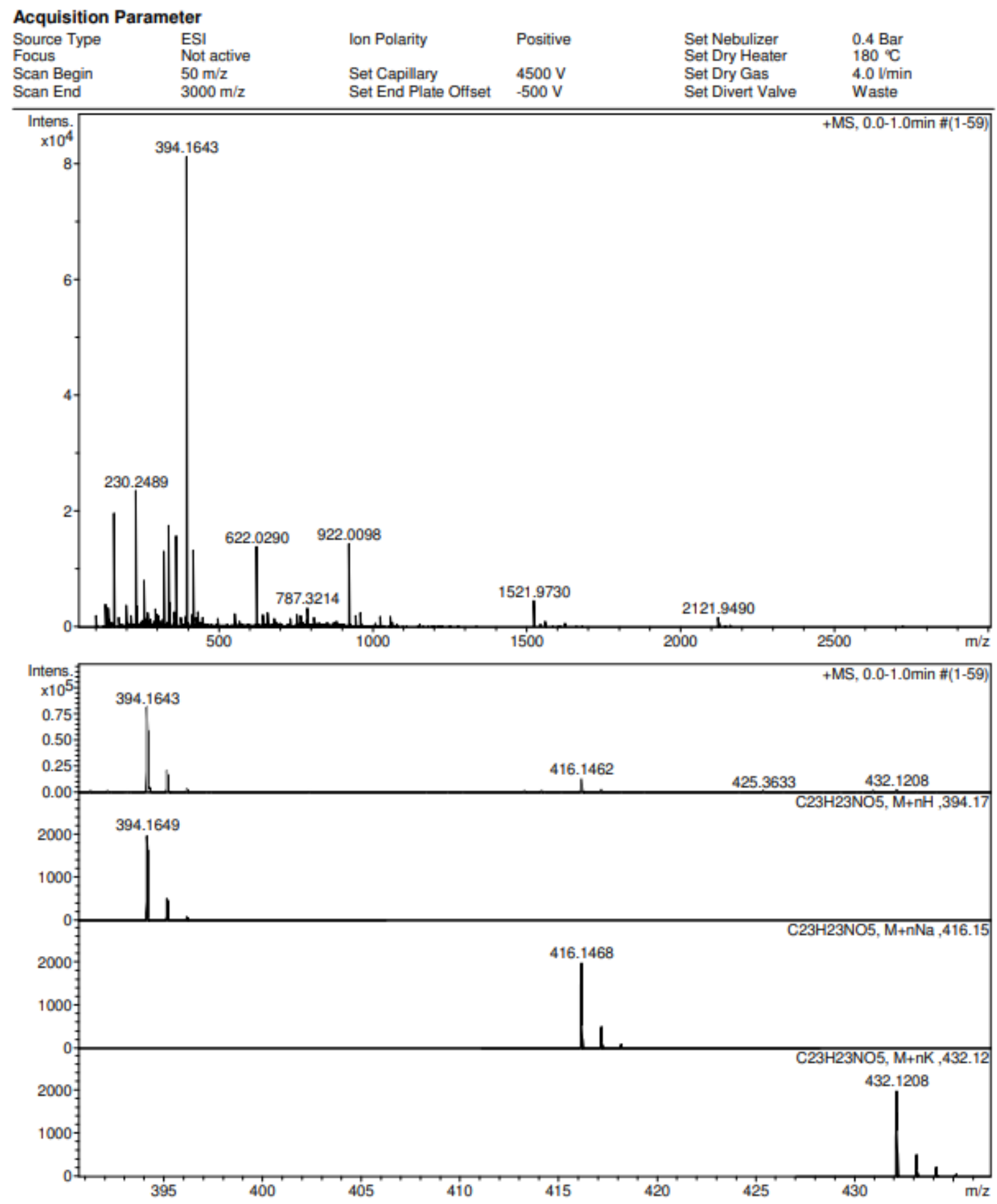
${ }^{1} \mathrm{H}$ NMR spectrum $(500 \mathrm{MHz})$ of $13 \mathrm{~g}$ in DMSO- $d_{6}$

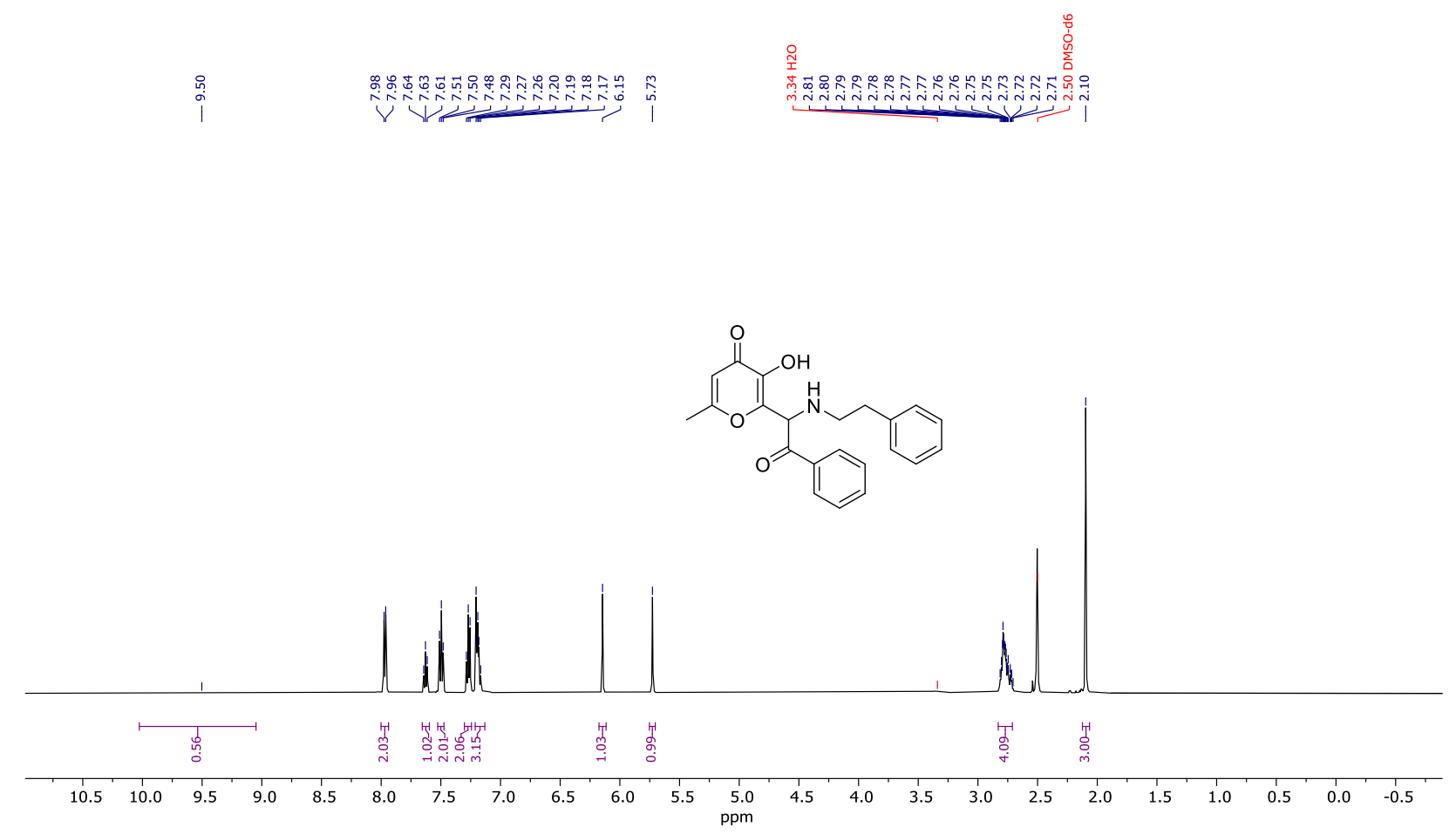

${ }^{13} \mathrm{C}\left\{{ }^{1} \mathrm{H}\right\}$ NMR spectrum $(126 \mathrm{MHz})$ of 13g in DMSO- $d_{6}$
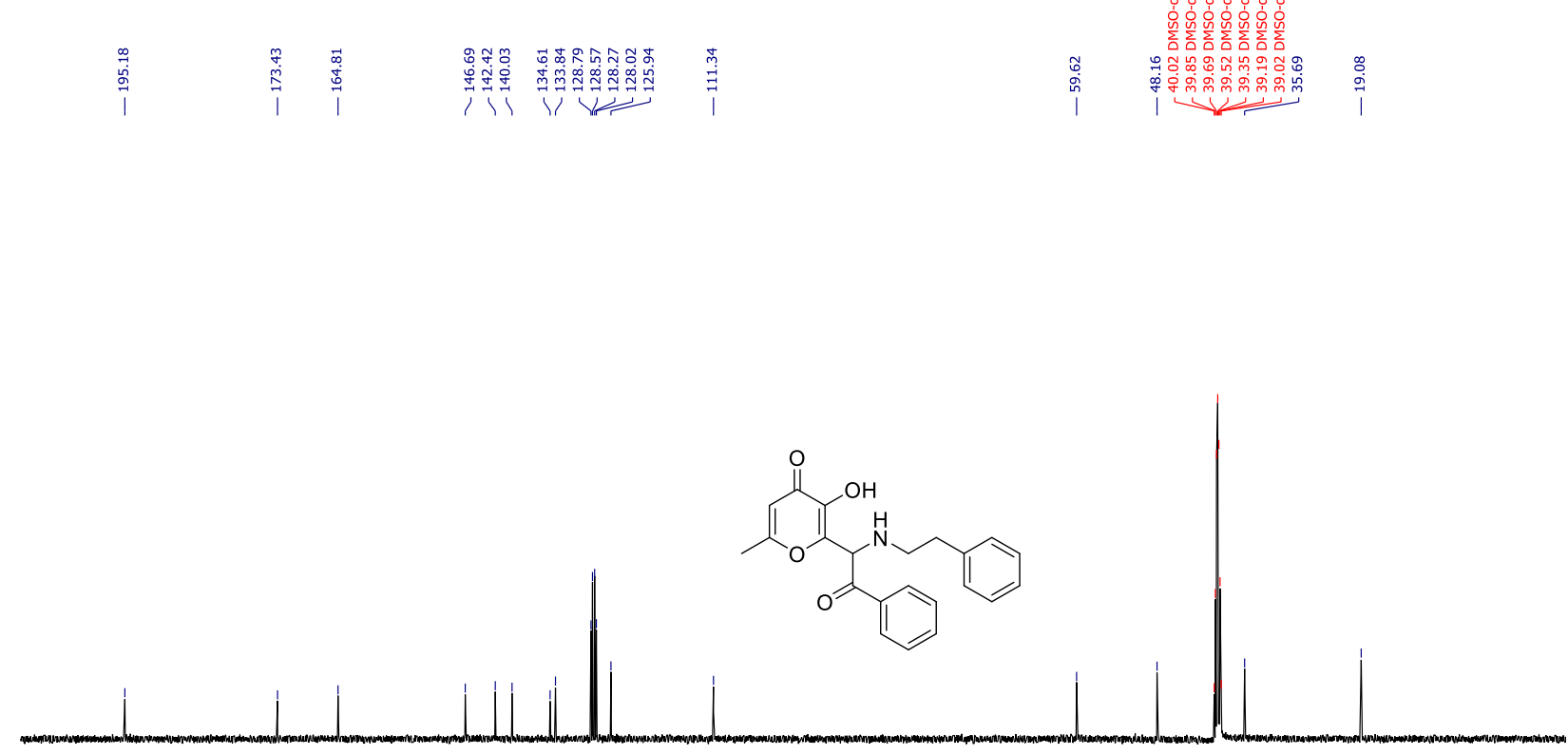

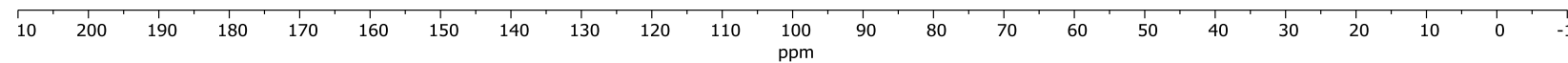


HRMS for compound 13g

Acquisition Parameter

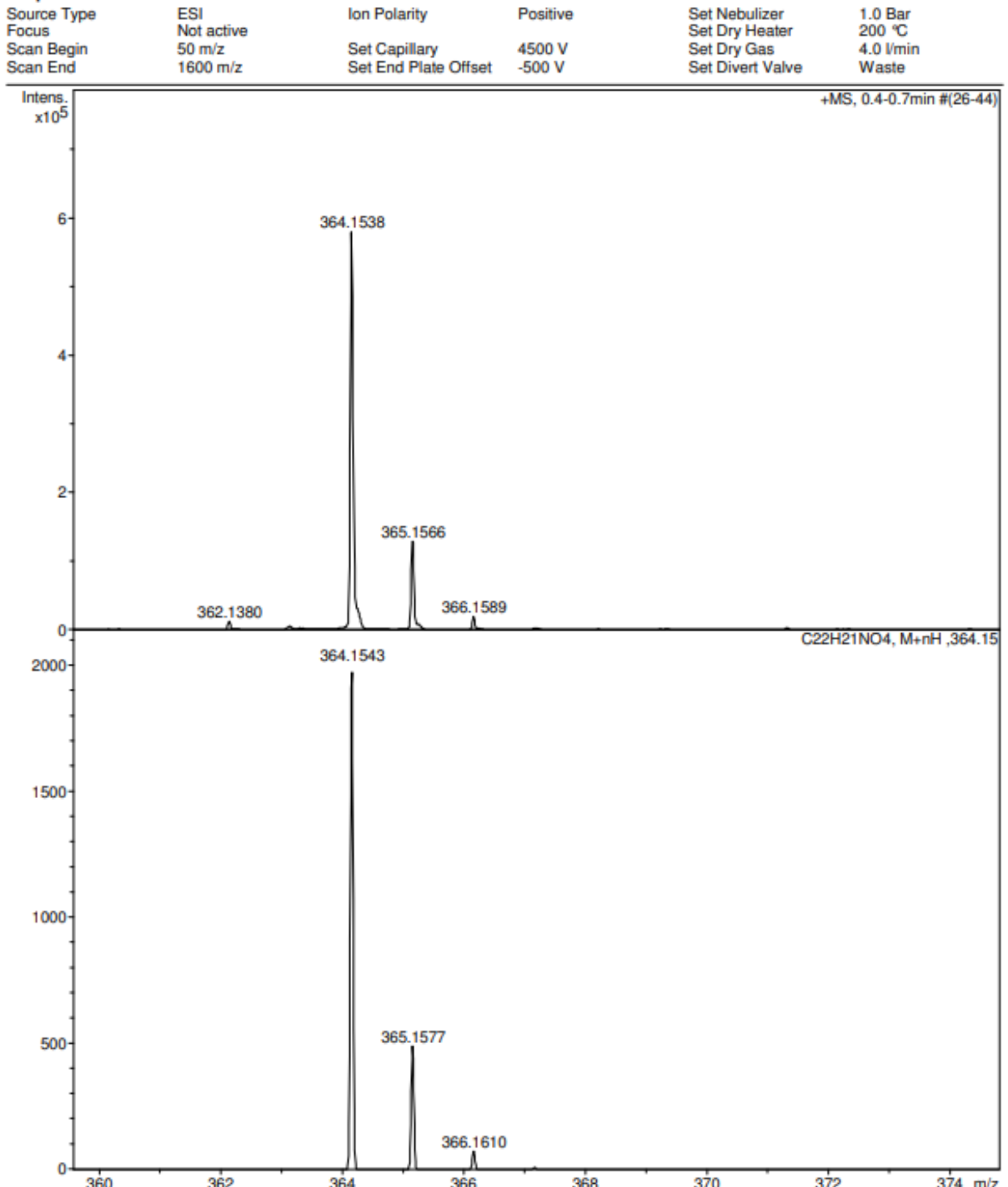


${ }^{1} \mathrm{H}$ NMR spectrum $\left(500 \mathrm{MHz}\right.$ ) of $13 \mathrm{~h}$ in DMSO- $d_{6}$

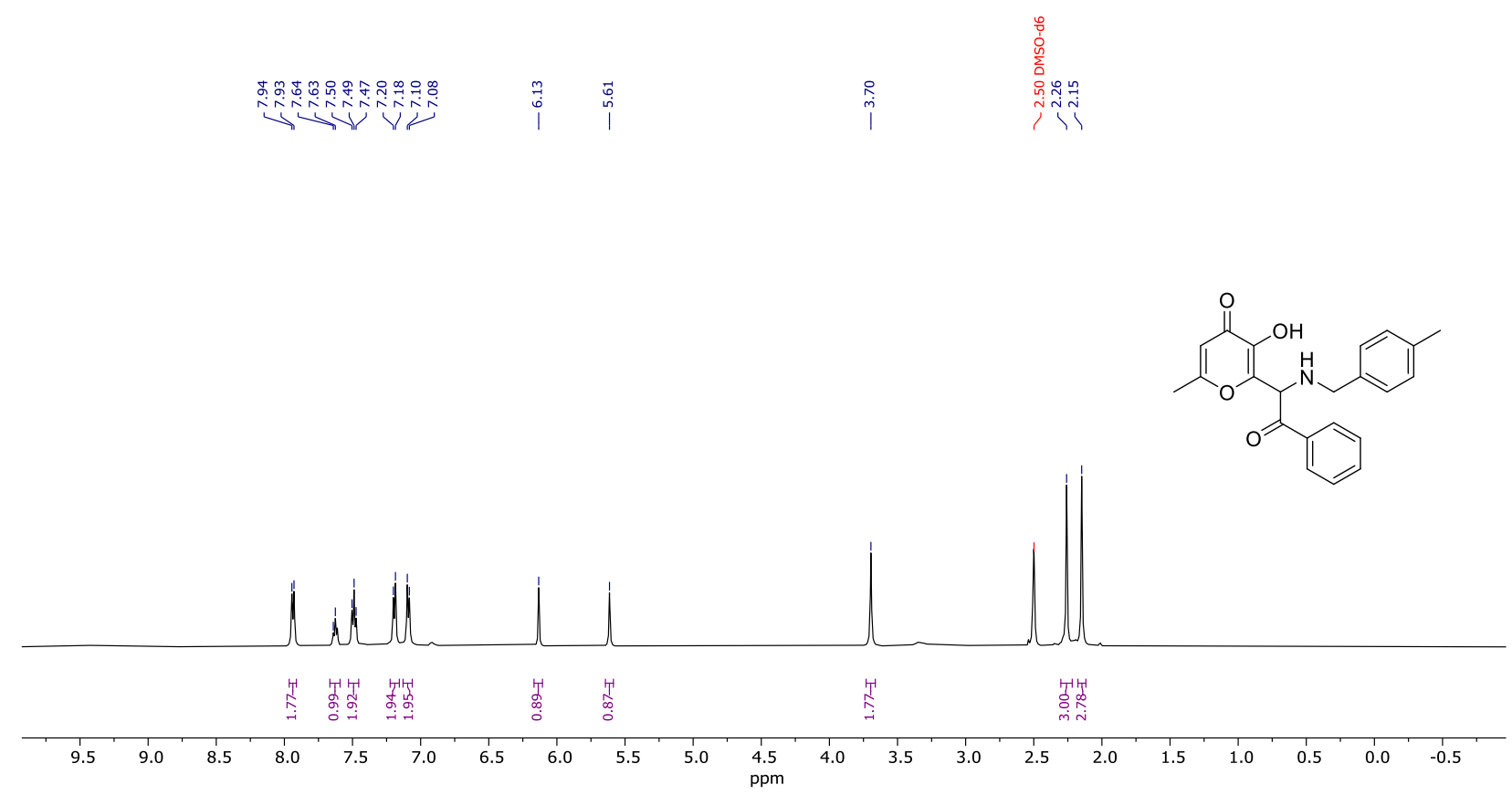

${ }^{13} \mathrm{C}\left\{{ }^{1} \mathrm{H}\right\}$ NMR spectrum (126 MHz) of $13 \mathrm{~h}$ in DMSO- $d_{6}$

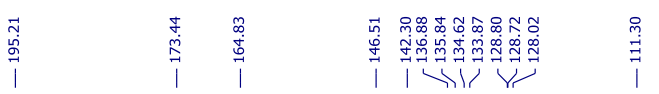
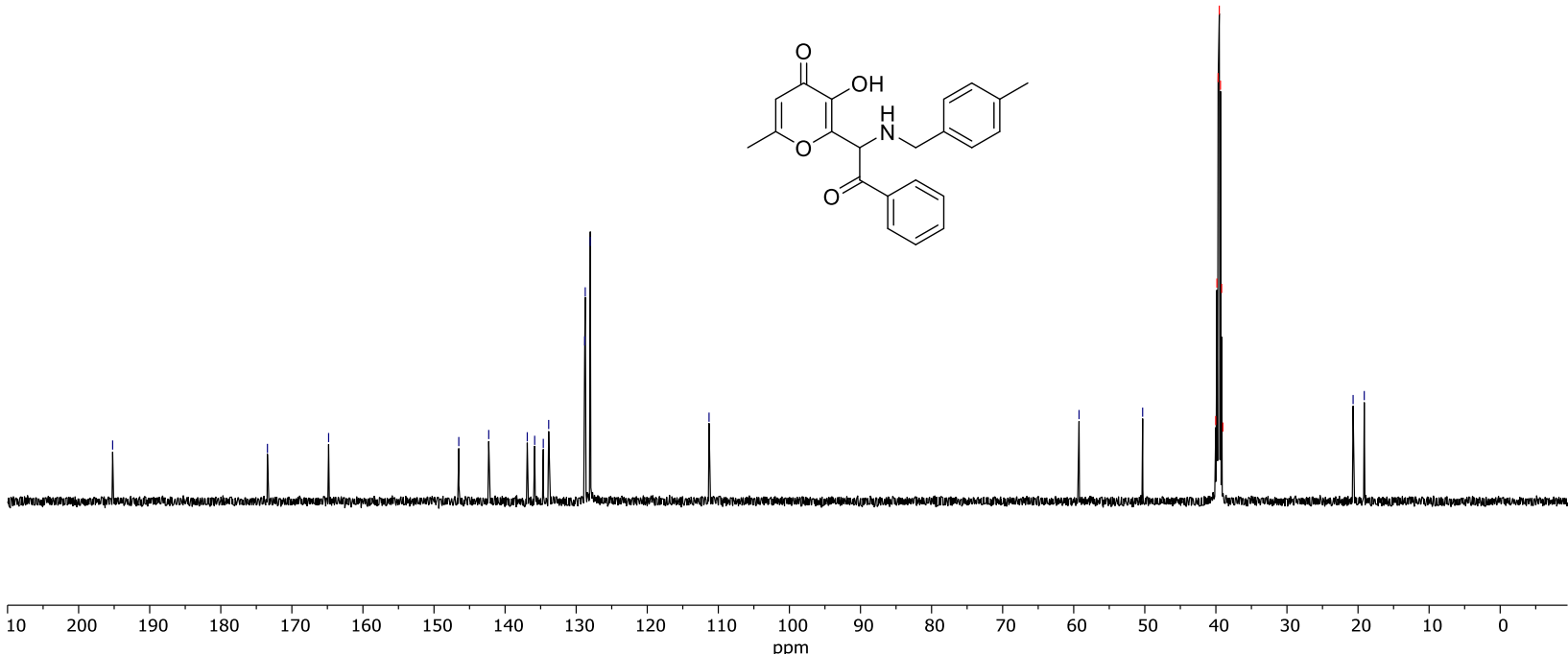
HRMS for compound $\mathbf{1 3 h}$

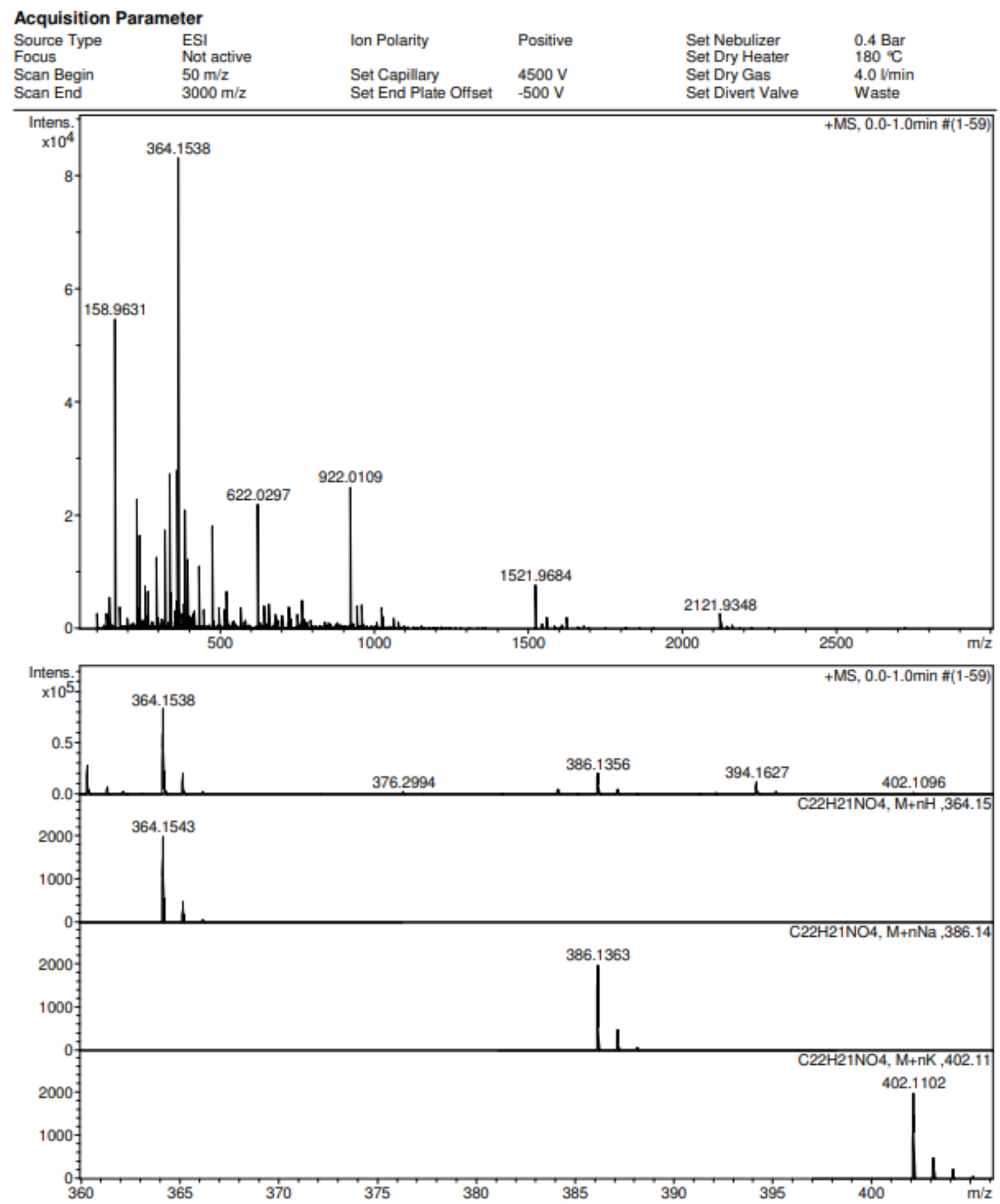


${ }^{1} \mathrm{H}$ NMR spectrum $\left(500 \mathrm{MHz}\right.$ ) of $13 \mathbf{i}$ in DMSO- $d_{6}$

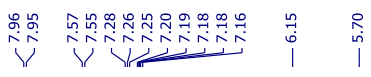
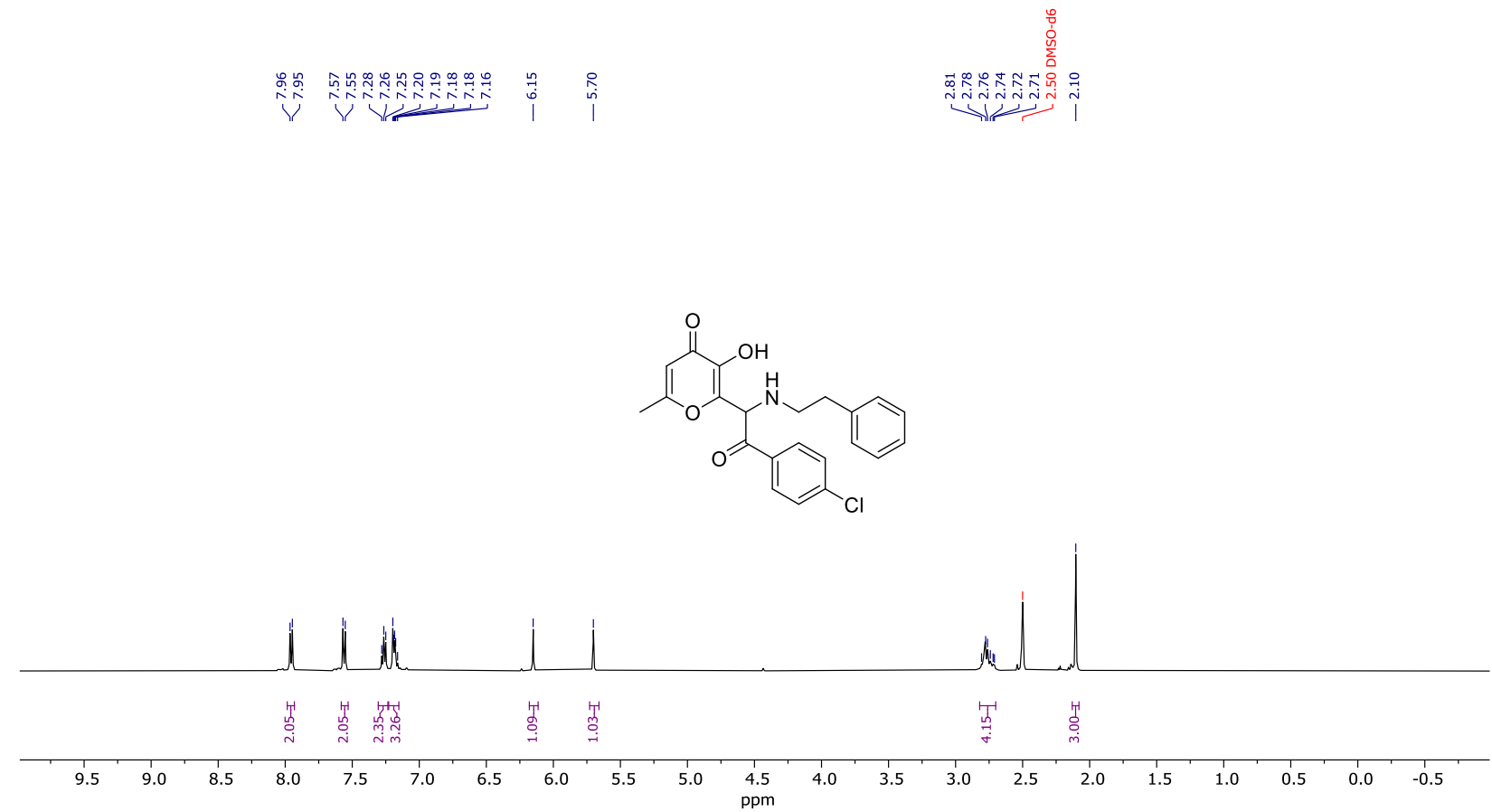

${ }^{13} \mathrm{C}\left\{{ }^{1} \mathrm{H}\right\}$ NMR spectrum (126 MHz) of $13 \mathbf{i}$ in DMSO- $d_{6}$
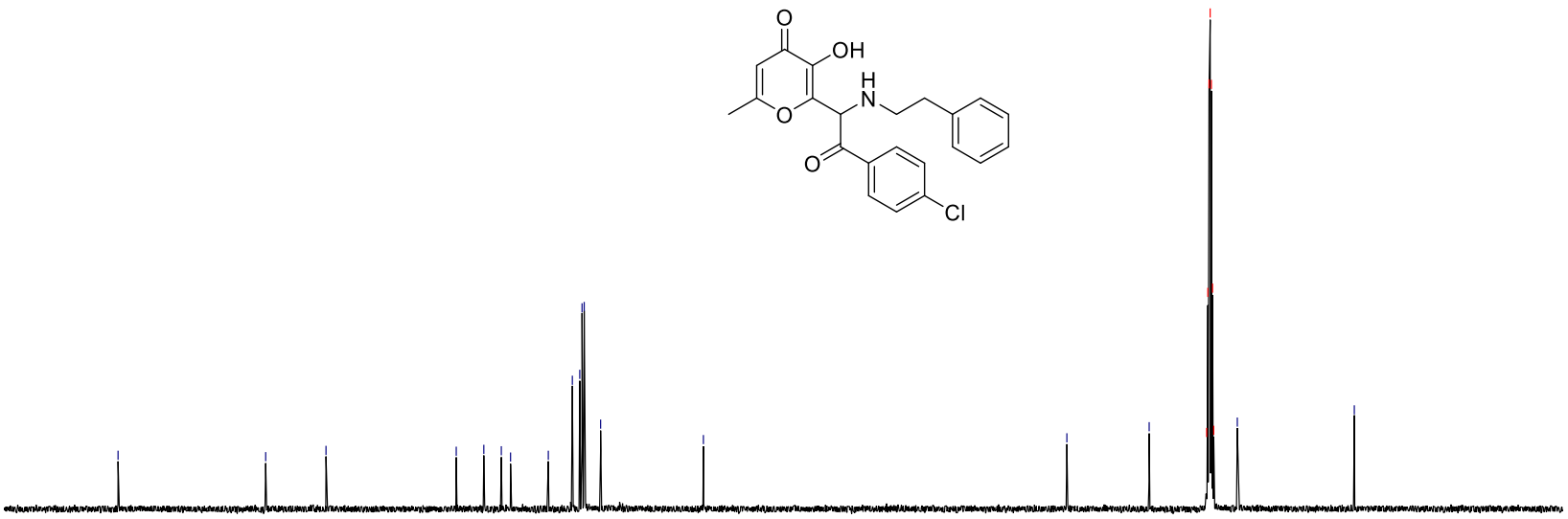

$\begin{array}{lllllllllllllllllllllllll}10 & 200 & 190 & 180 & 170 & 160 & 150 & 140 & 130 & 120 & 110 & 100 & 90 & 80 & 70 & 60 & 50 & 40 & 30 & 20 & 10 & 0 & -1\end{array}$ 
HRMS for compound $\mathbf{1 3 \mathbf { i }}$

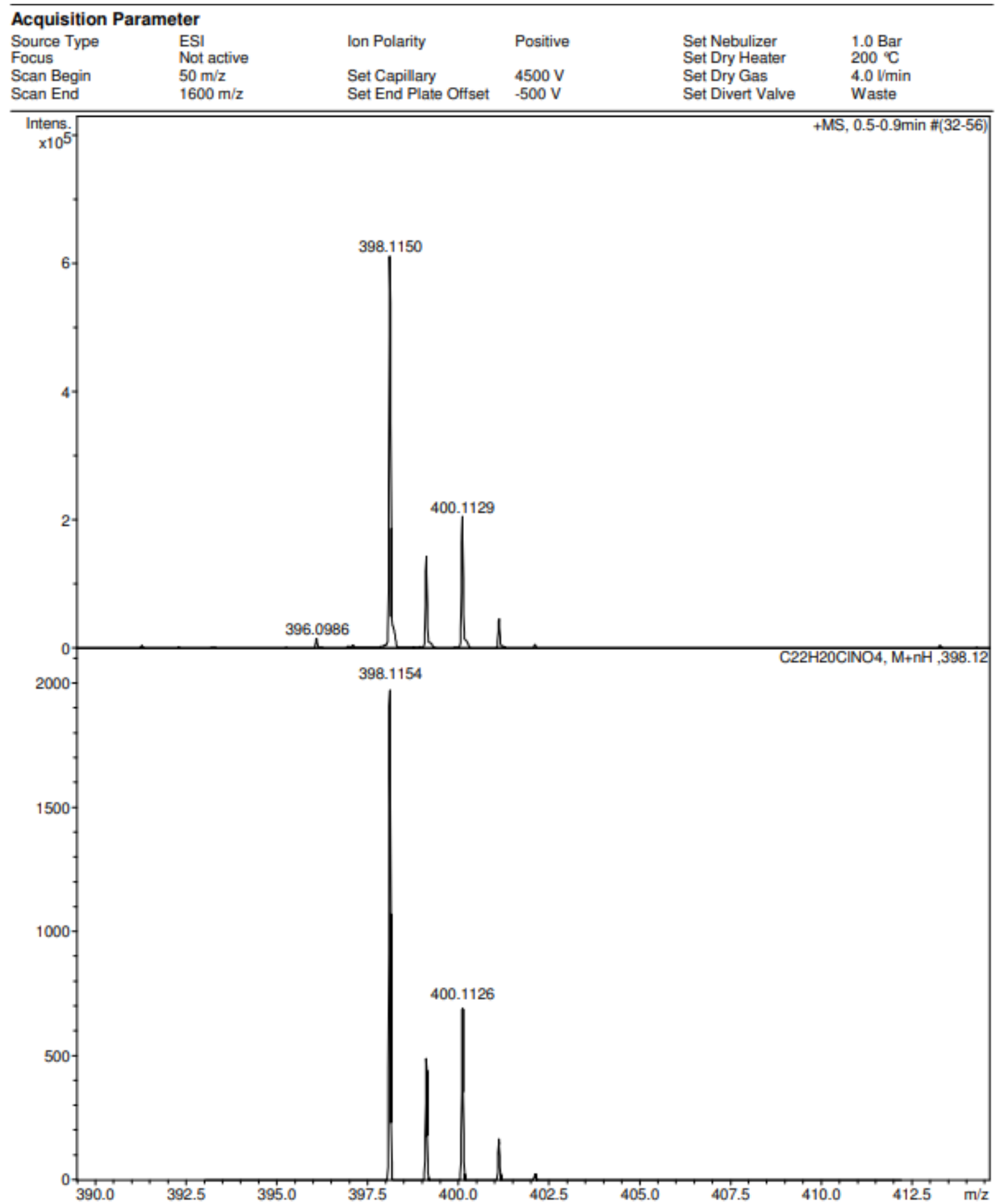


${ }^{1} \mathrm{H}$ NMR spectrum $(300 \mathrm{MHz})$ of $13 \mathbf{k}$ in DMSO- $d_{6}$
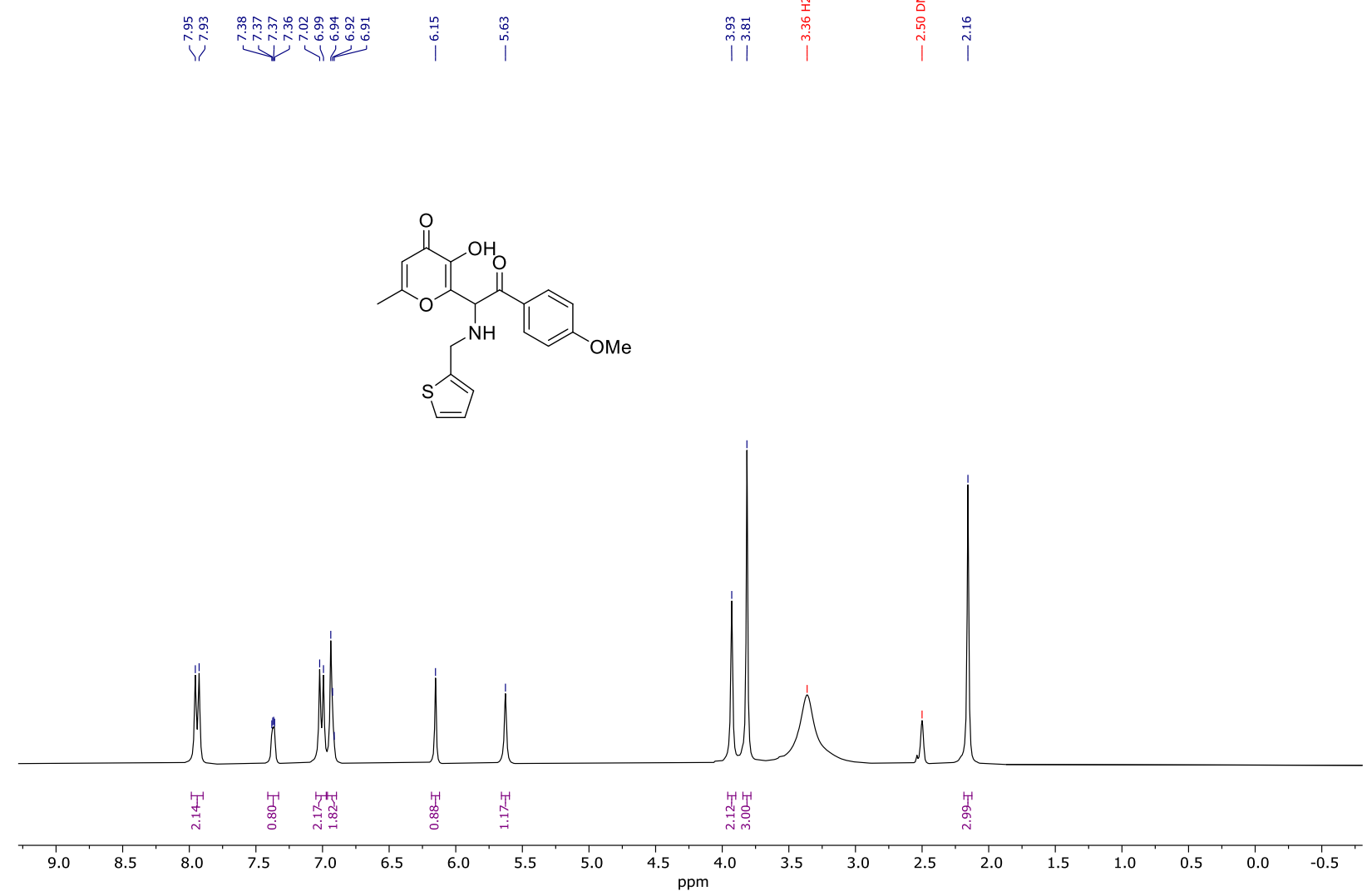

${ }^{13} \mathrm{C}\left\{{ }^{1} \mathrm{H}\right\}$ NMR spectrum $\left(75 \mathrm{MHz}\right.$ ) of 13k in DMSO- $d_{6}$

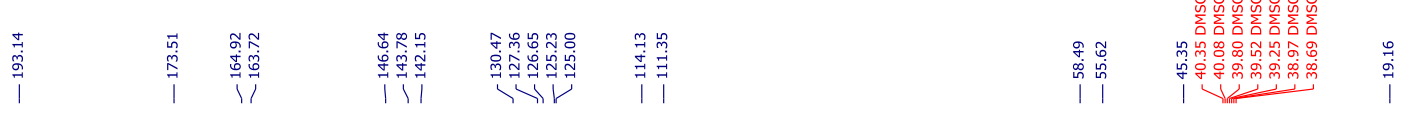

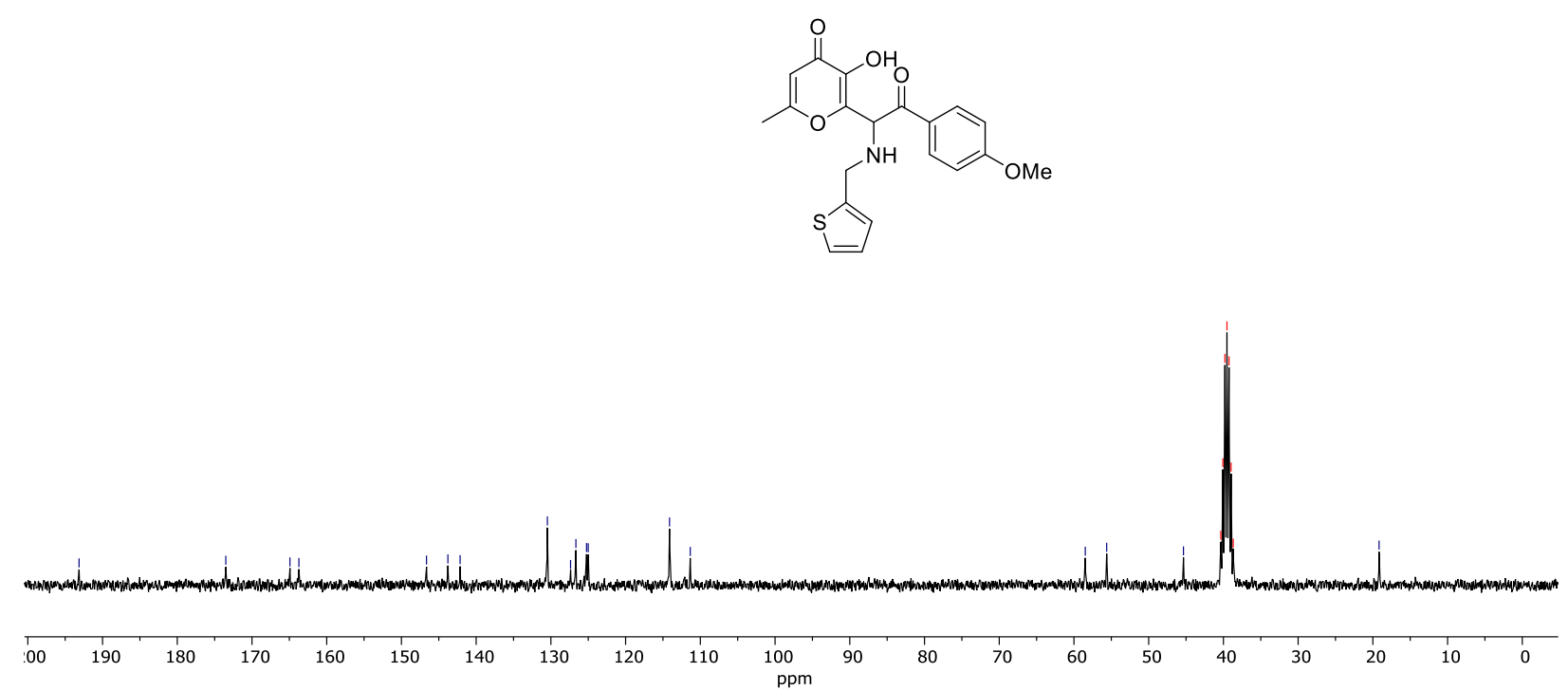


HRMS for compound 13k

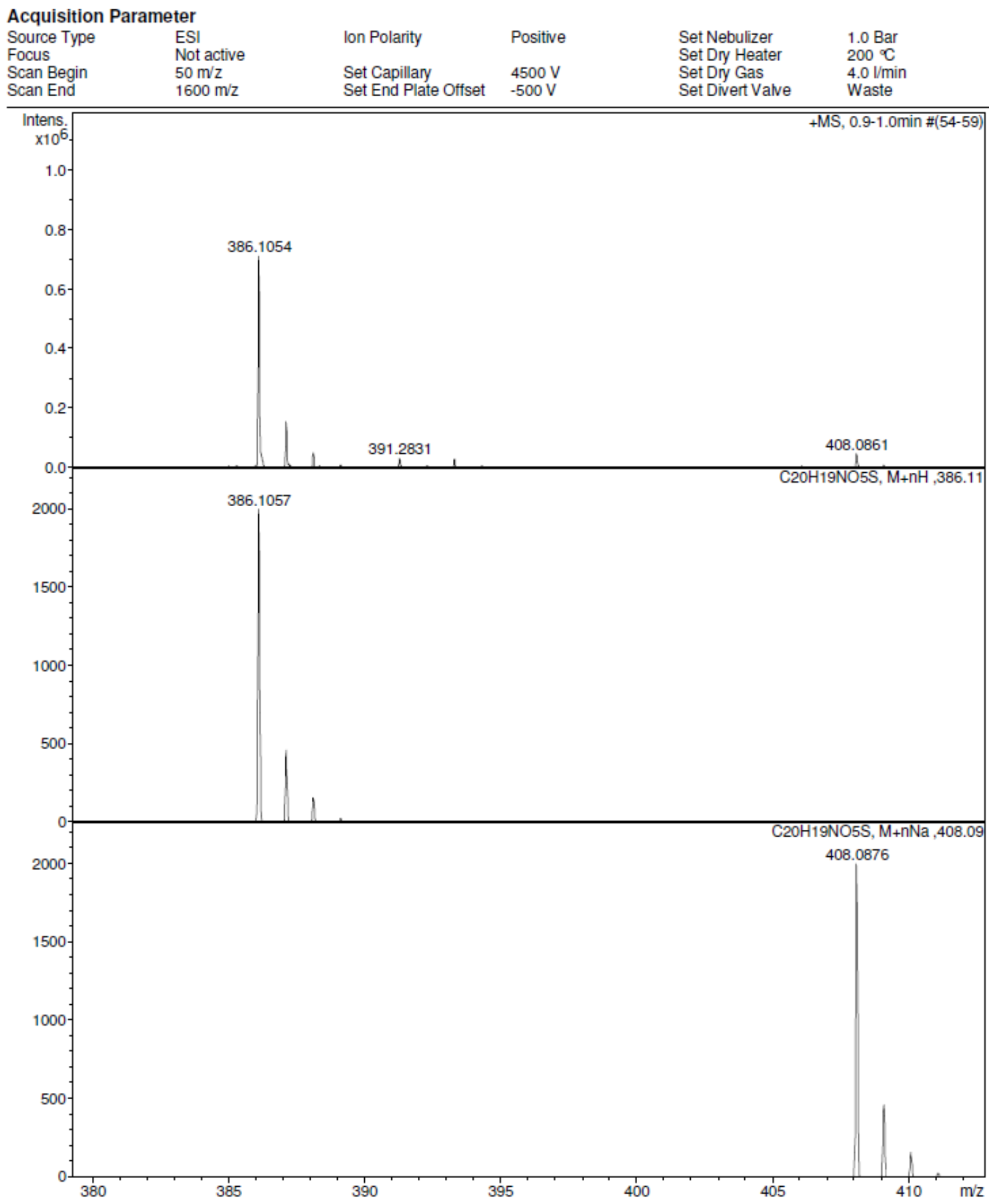


4. Copies of ${ }^{1} \mathrm{H},{ }^{13} \mathrm{C}$ NMR and HRMS for oxazol-2(3H)-ones 12.

${ }^{1} \mathrm{H}$ NMR spectrum $\left(300 \mathrm{MHz}\right.$ ) of 12a in DMSO- $d_{6}$

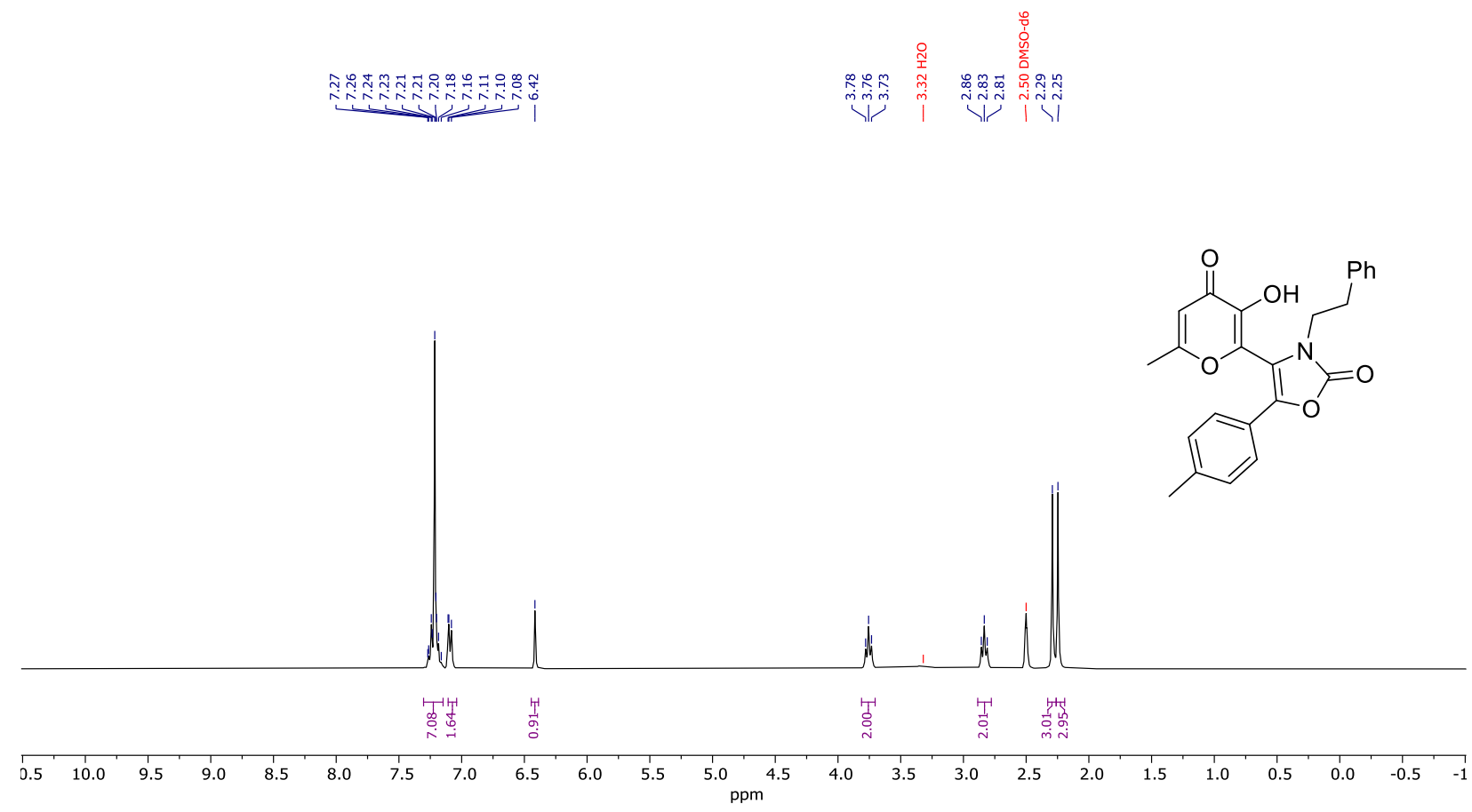

${ }^{13} \mathrm{C}\left\{{ }^{1} \mathrm{H}\right\}$ NMR spectrum (126 MHz) of 12a in DMSO- $d_{6}$
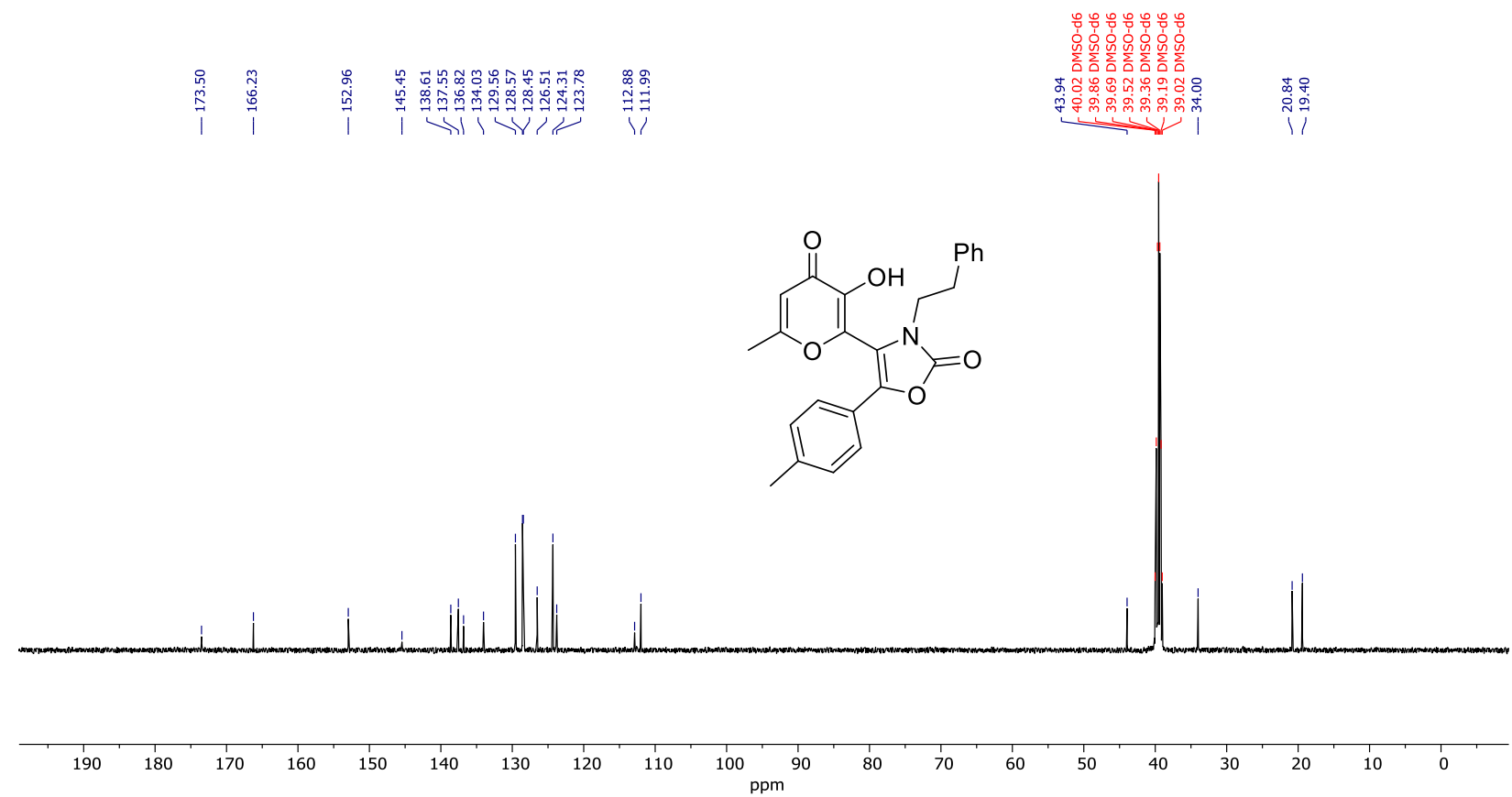
HRMS for compound 12a

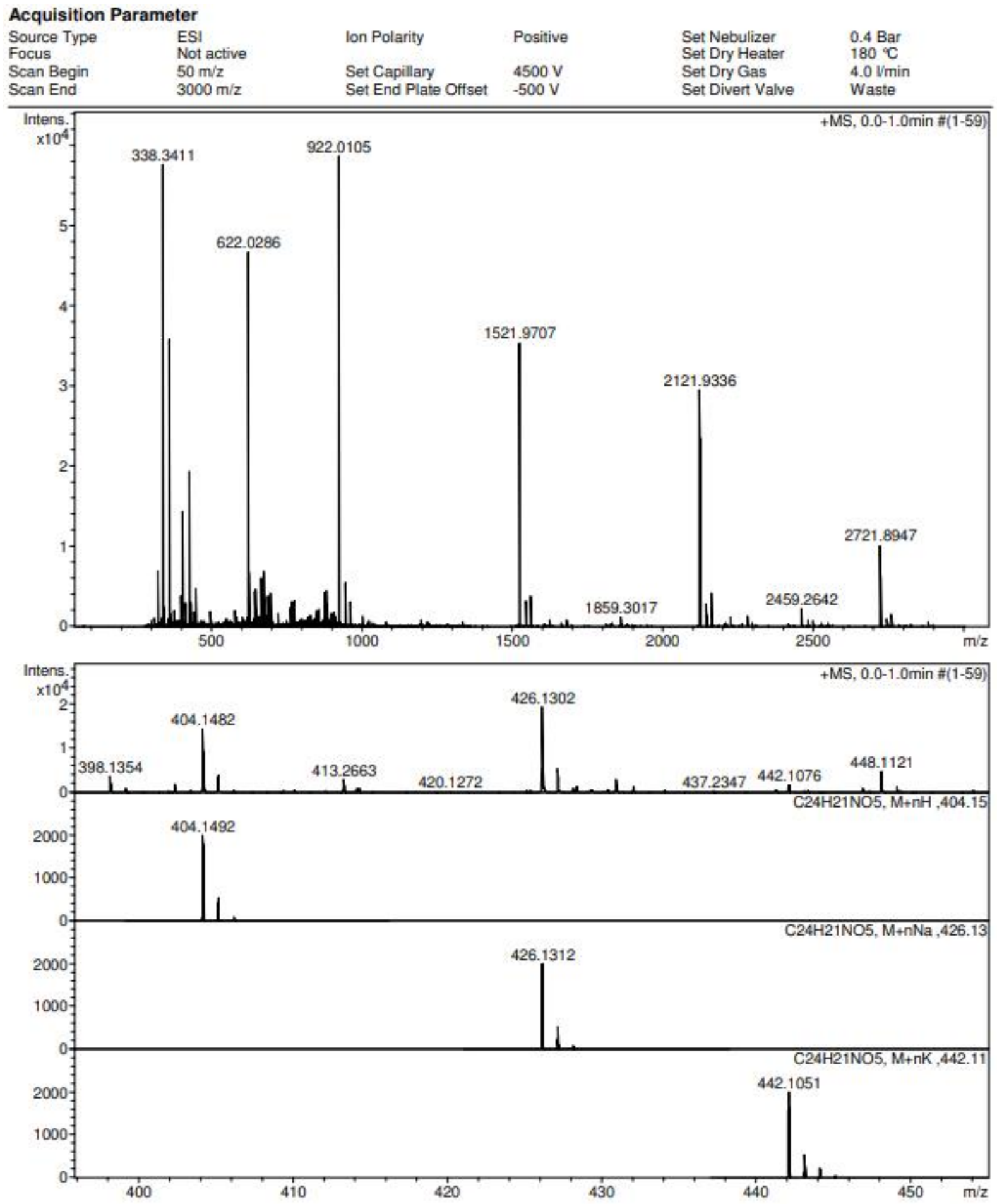


${ }^{1} \mathrm{H}$ NMR spectrum $\left(300 \mathrm{MHz}\right.$ ) of $\mathbf{1 2} \mathbf{b}$ in DMSO- $d_{6}$

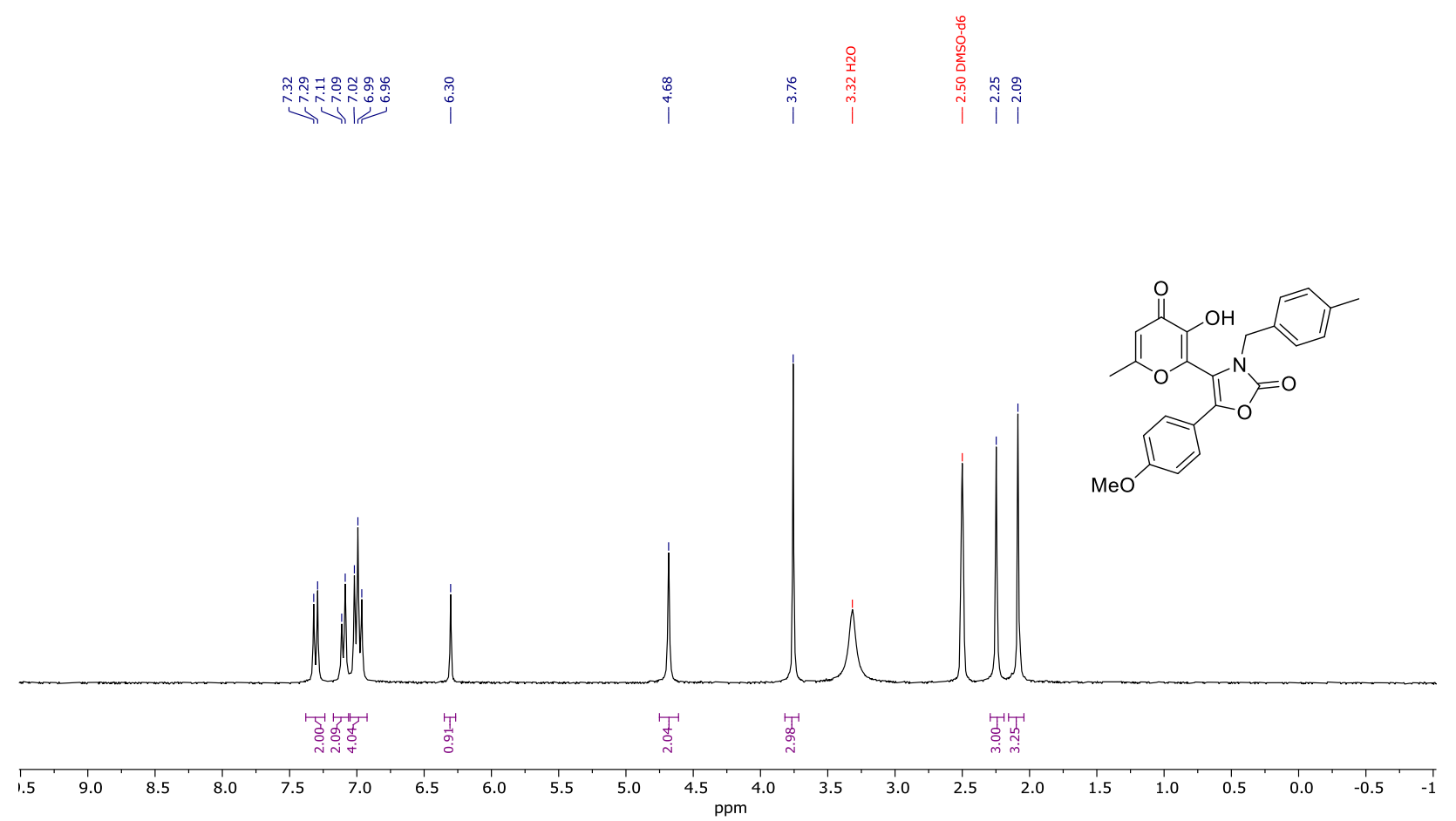

${ }^{13} \mathrm{C}\left\{{ }^{1} \mathrm{H}\right\}$ NMR spectrum (126 MHz) of $\mathbf{1 2} \mathbf{b}$ in DMSO- $d_{6}$

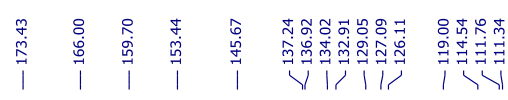
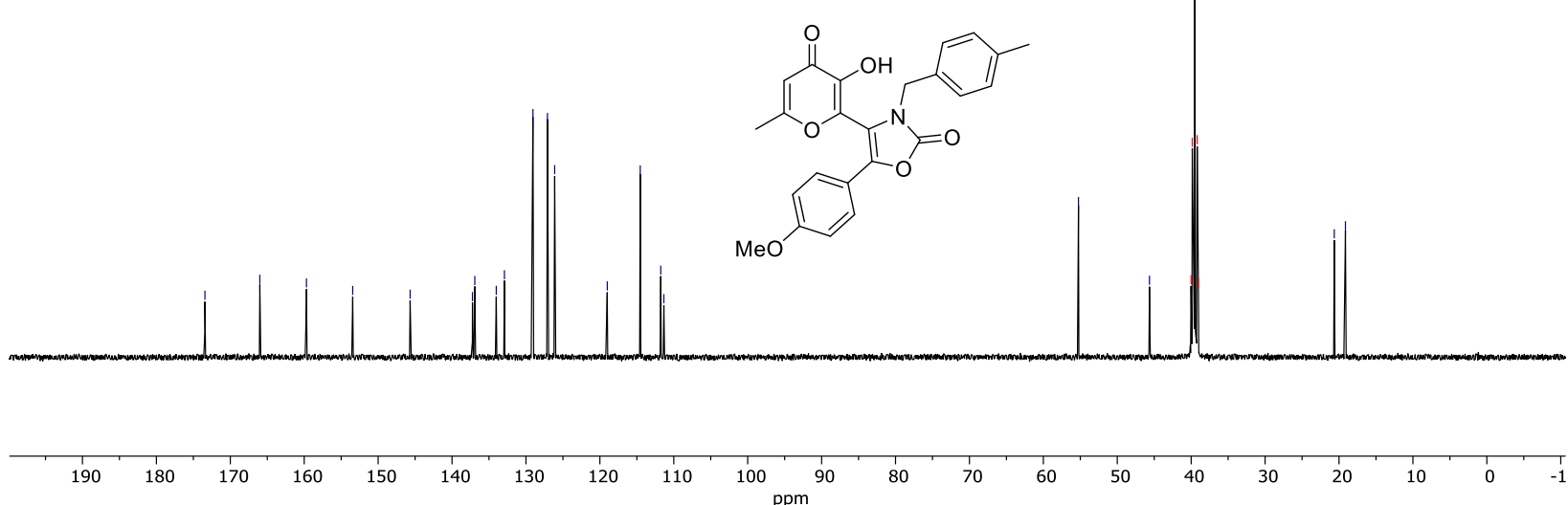
HRMS for compound $\mathbf{1 2 b}$

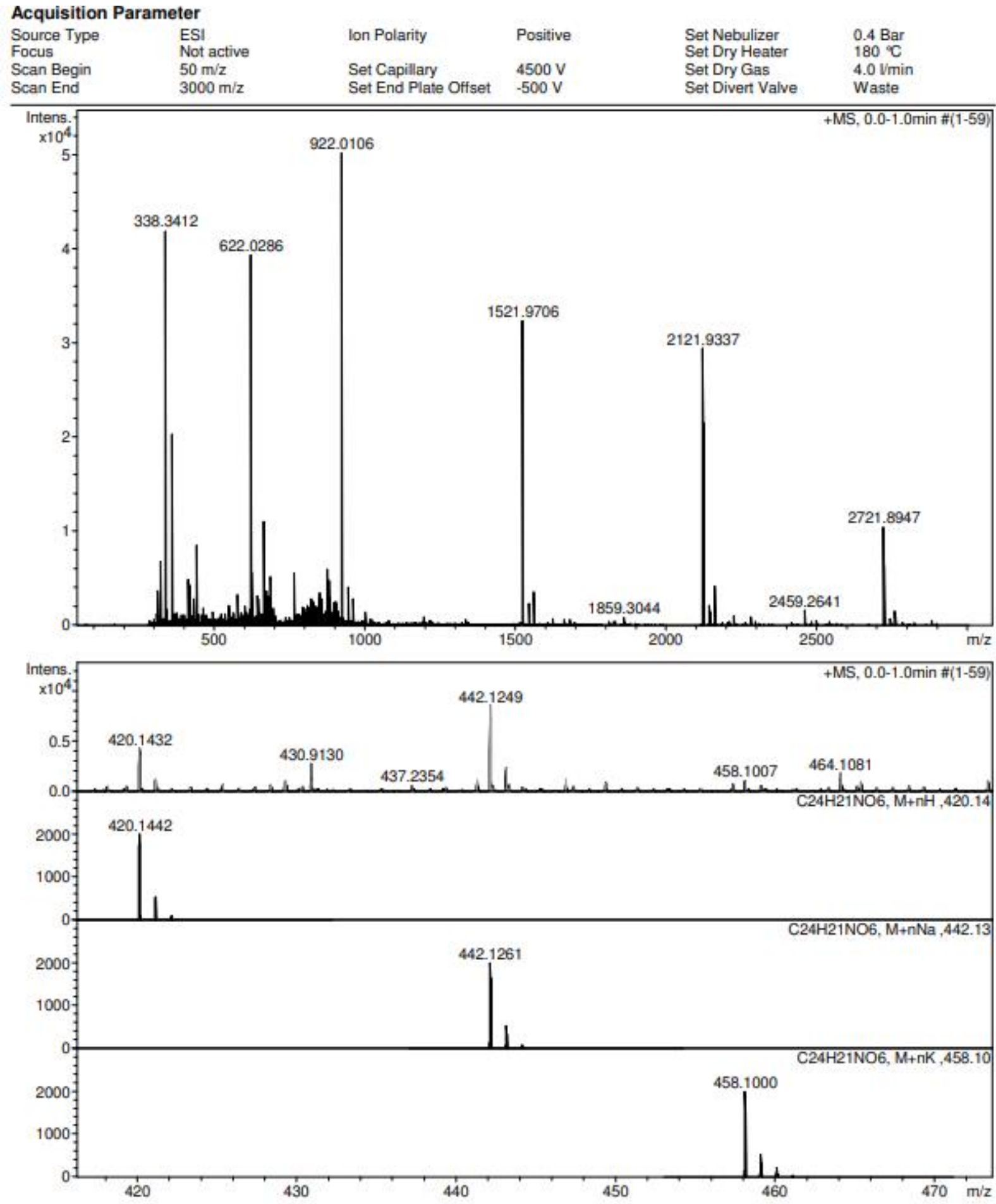


${ }^{1} \mathrm{H}$ NMR spectrum $(300 \mathrm{MHz})$ of $12 \mathrm{c}$ in DMSO- $d_{6}$

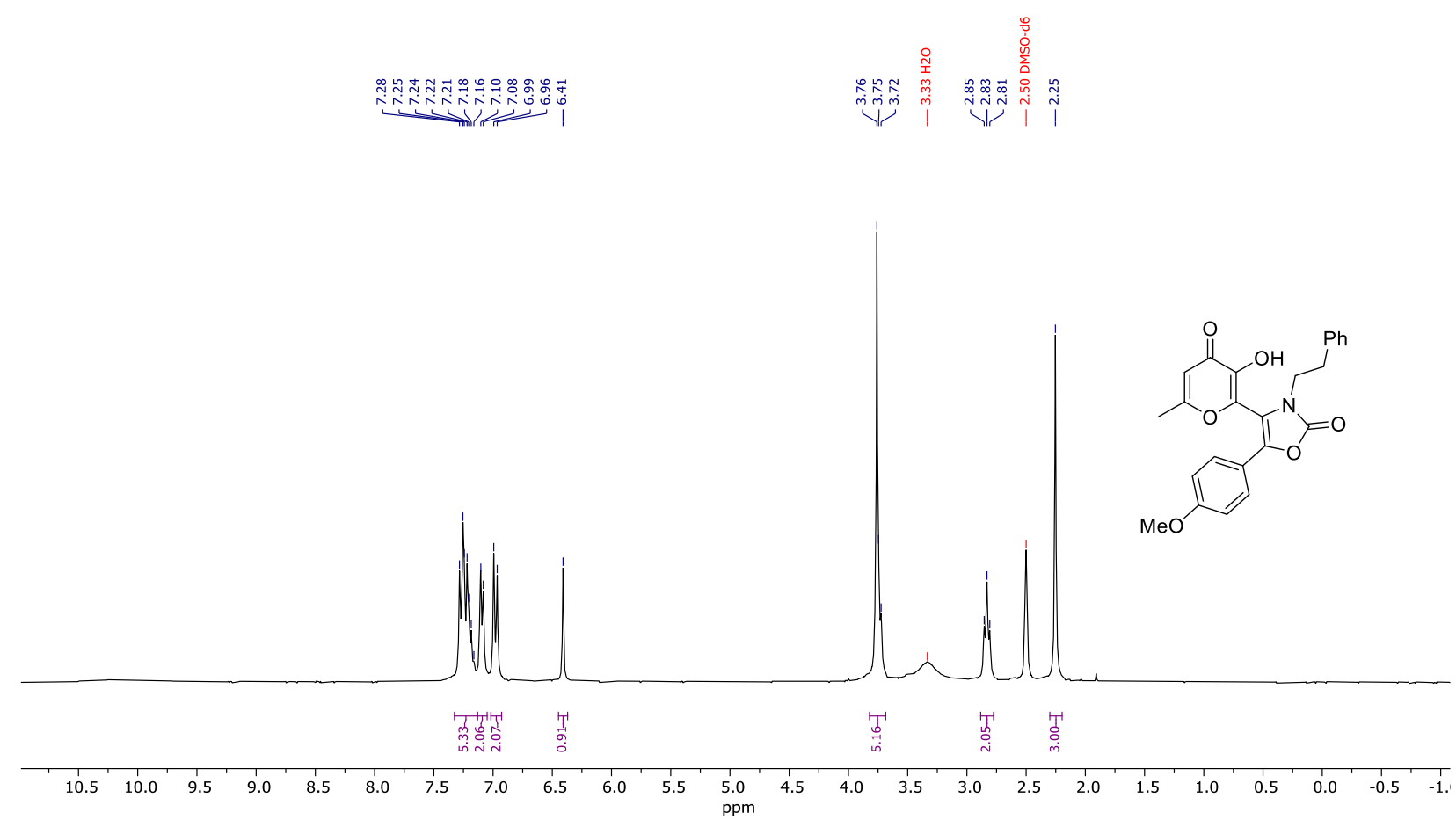

${ }^{13} \mathrm{C}\left\{{ }^{1} \mathrm{H}\right\}$ NMR spectrum (75 MHz) of $12 \mathrm{c}$ in DMSO- $d_{6}$

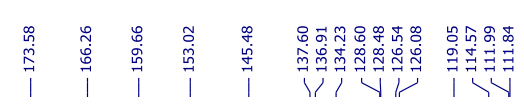

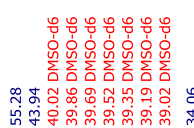

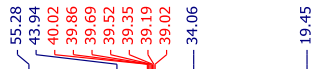

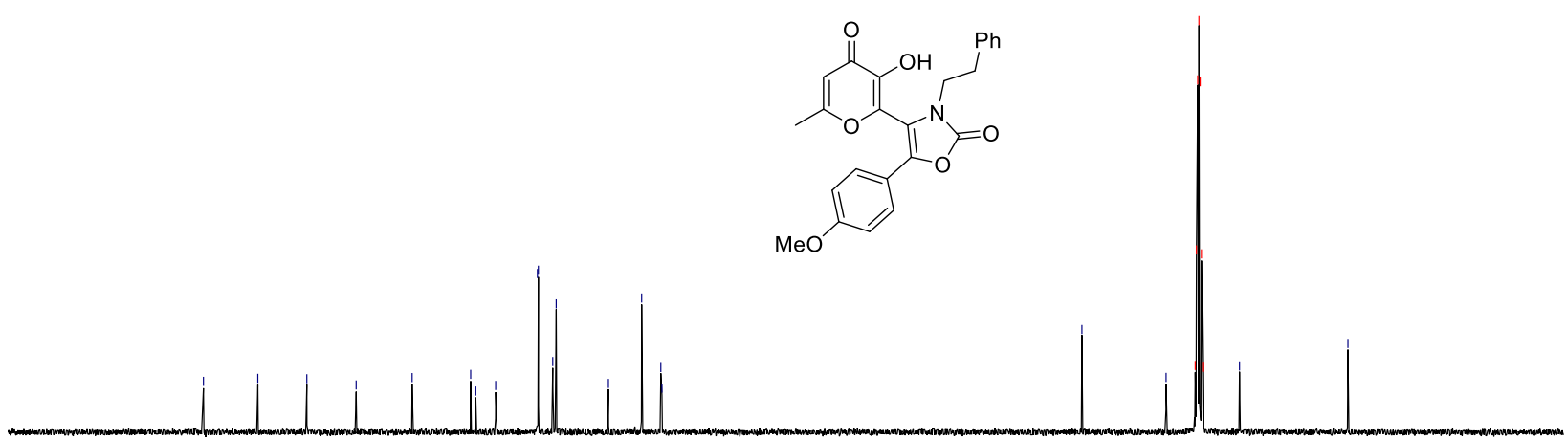

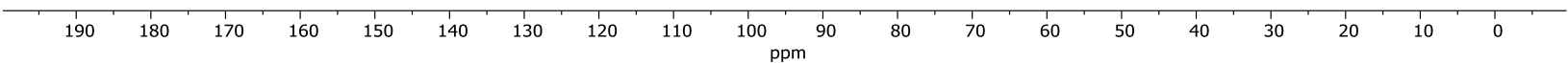


HRMS for compound 12c

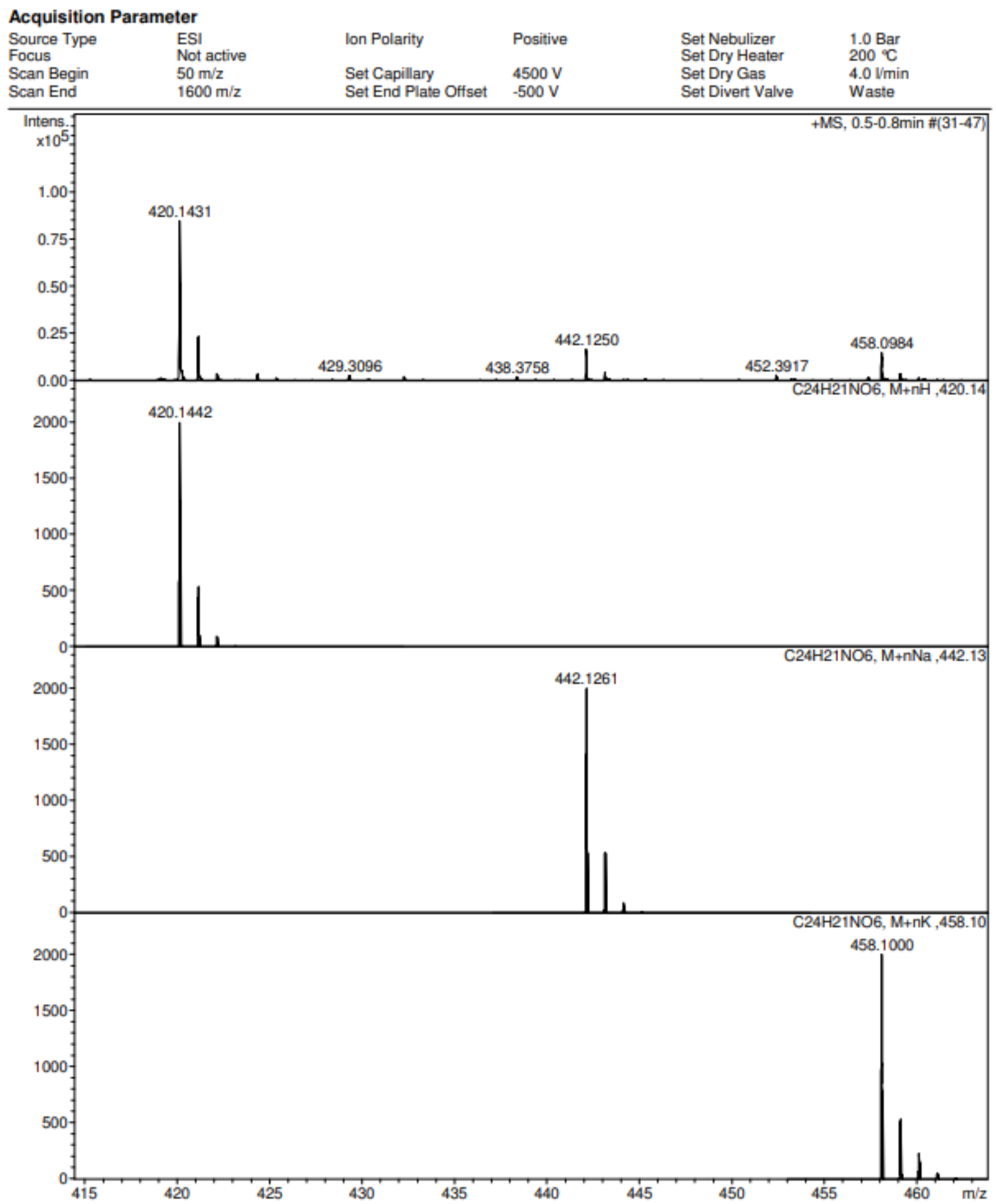


${ }^{1} \mathrm{H}$ NMR spectrum $\left(300 \mathrm{MHz}\right.$ ) of $\mathbf{1 2} \mathbf{d}$ in DMSO- $d_{6}$

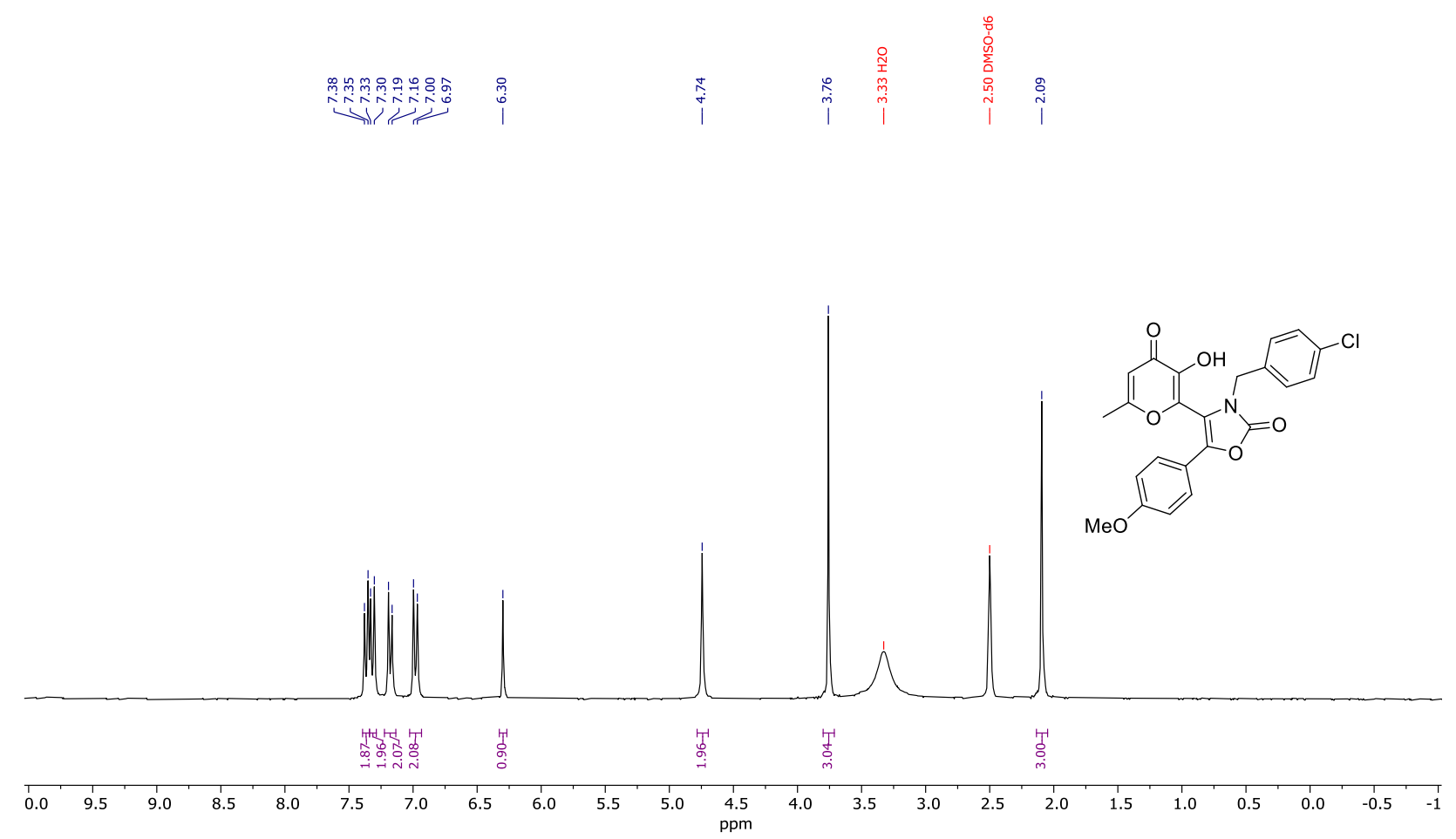

${ }^{13} \mathrm{C}\left\{{ }^{1} \mathrm{H}\right\}$ NMR spectrum (75 MHz) of $\mathbf{1 2 d}$ in DMSO- $d_{6}$

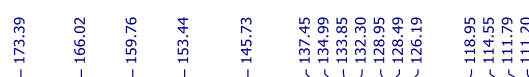

| |

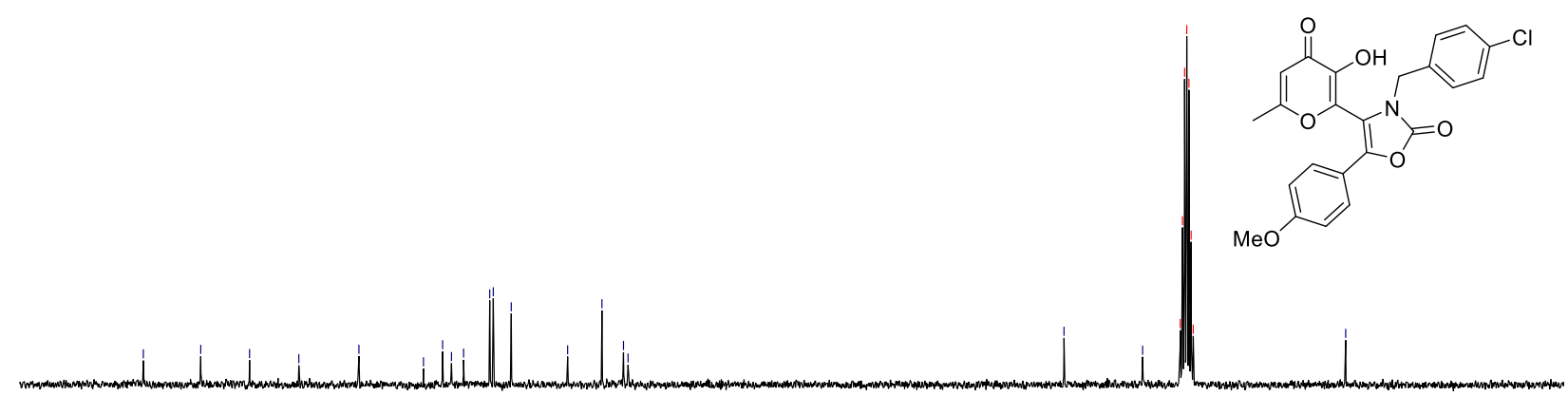

$120 \quad 110$

100 
HRMS for compound $\mathbf{1 2 d}$

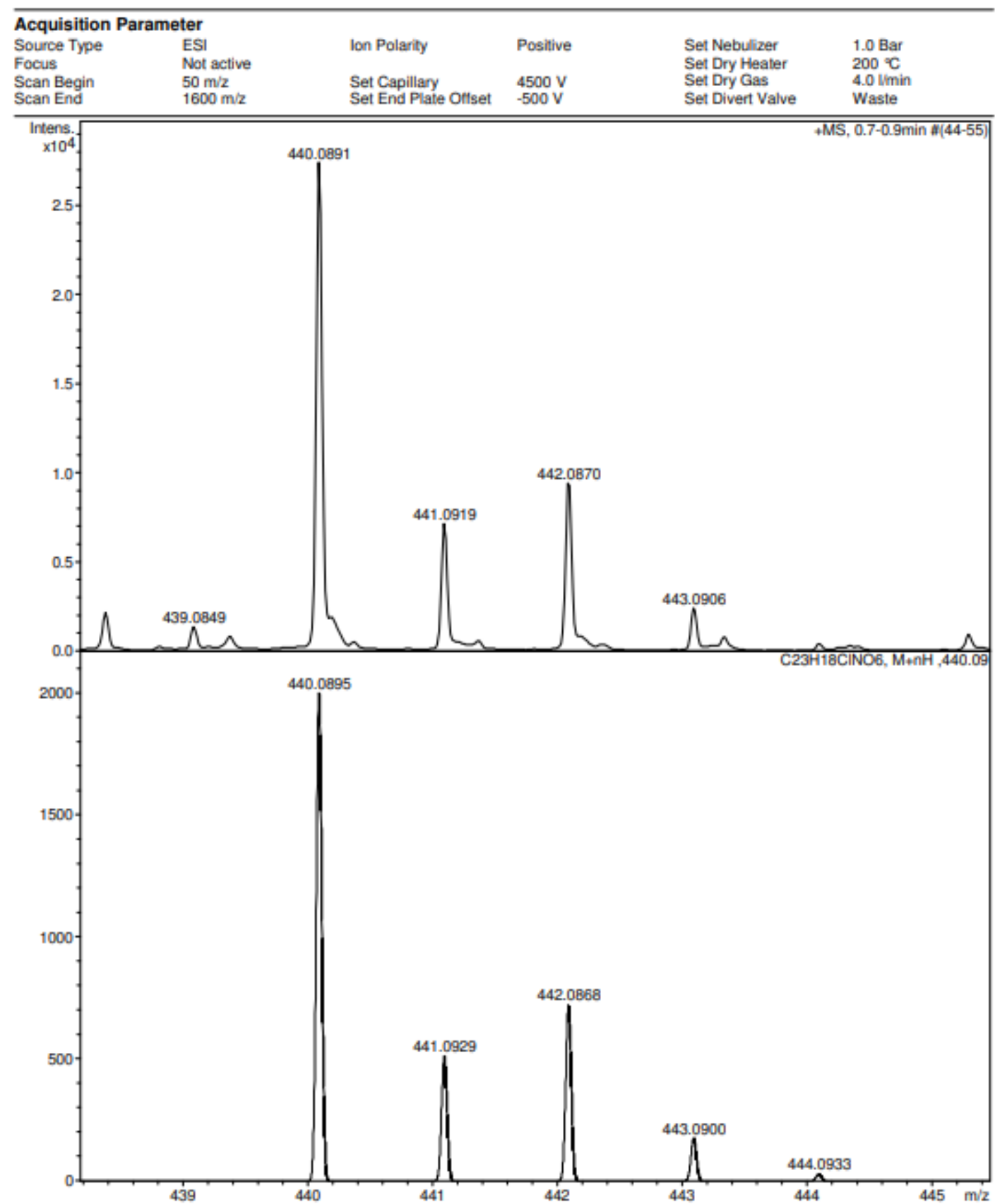


${ }^{1} \mathrm{H}$ NMR spectrum $\left(300 \mathrm{MHz}\right.$ ) of $12 \mathrm{e}$ in DMSO- $d_{6}$

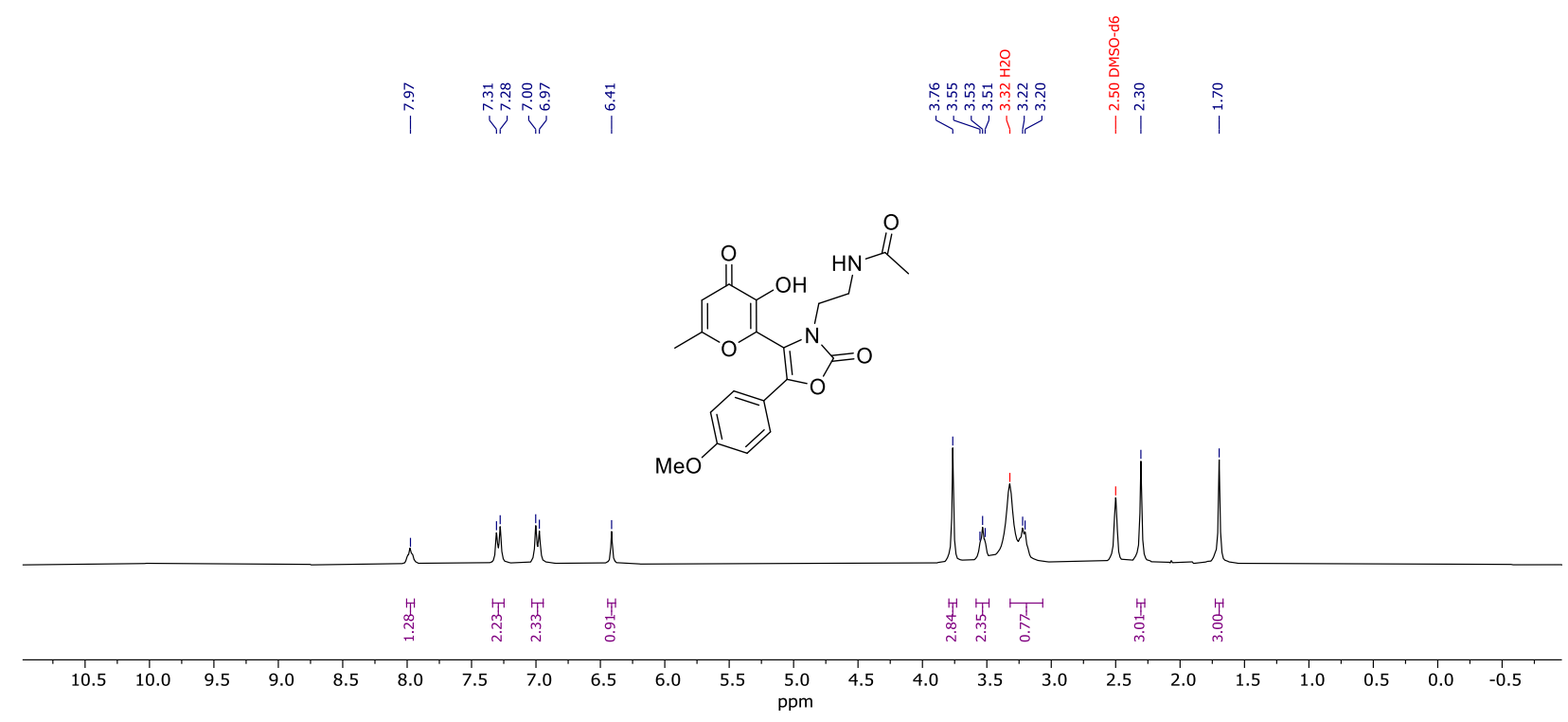

${ }^{13} \mathrm{C}\left\{{ }^{1} \mathrm{H}\right\}$ NMR spectrum (126 MHz) of $12 \mathbf{e}$ in DMSO- $d_{6}$

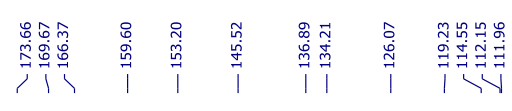
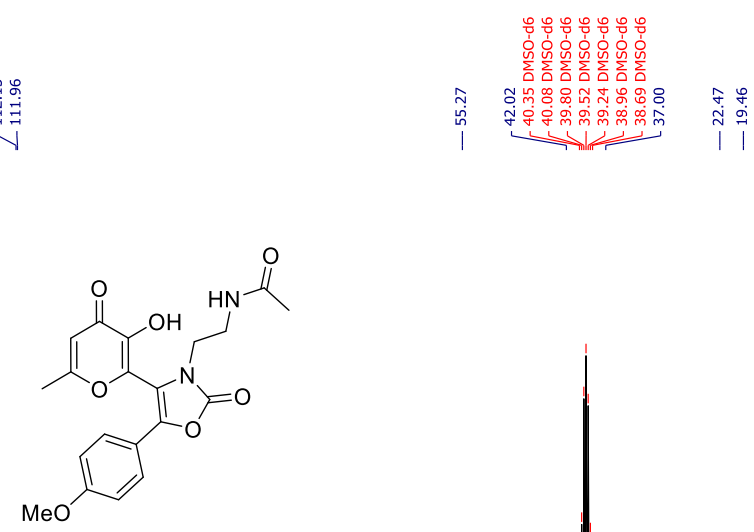

$190 \quad 180 \quad 170$

$100 \quad 90$

$80,70,60$

50

30 
HRMS for compound 12e

Acquisition Parameter

Source Type ES!

Focus Not active

Scan Begin $\quad 50 \mathrm{~m} / \mathrm{z}$

Scan End $\quad 1600 \mathrm{~m} / \mathrm{z}$

Positive

Set Capillary

Set End Plate Offset

$4500 \mathrm{~V}$

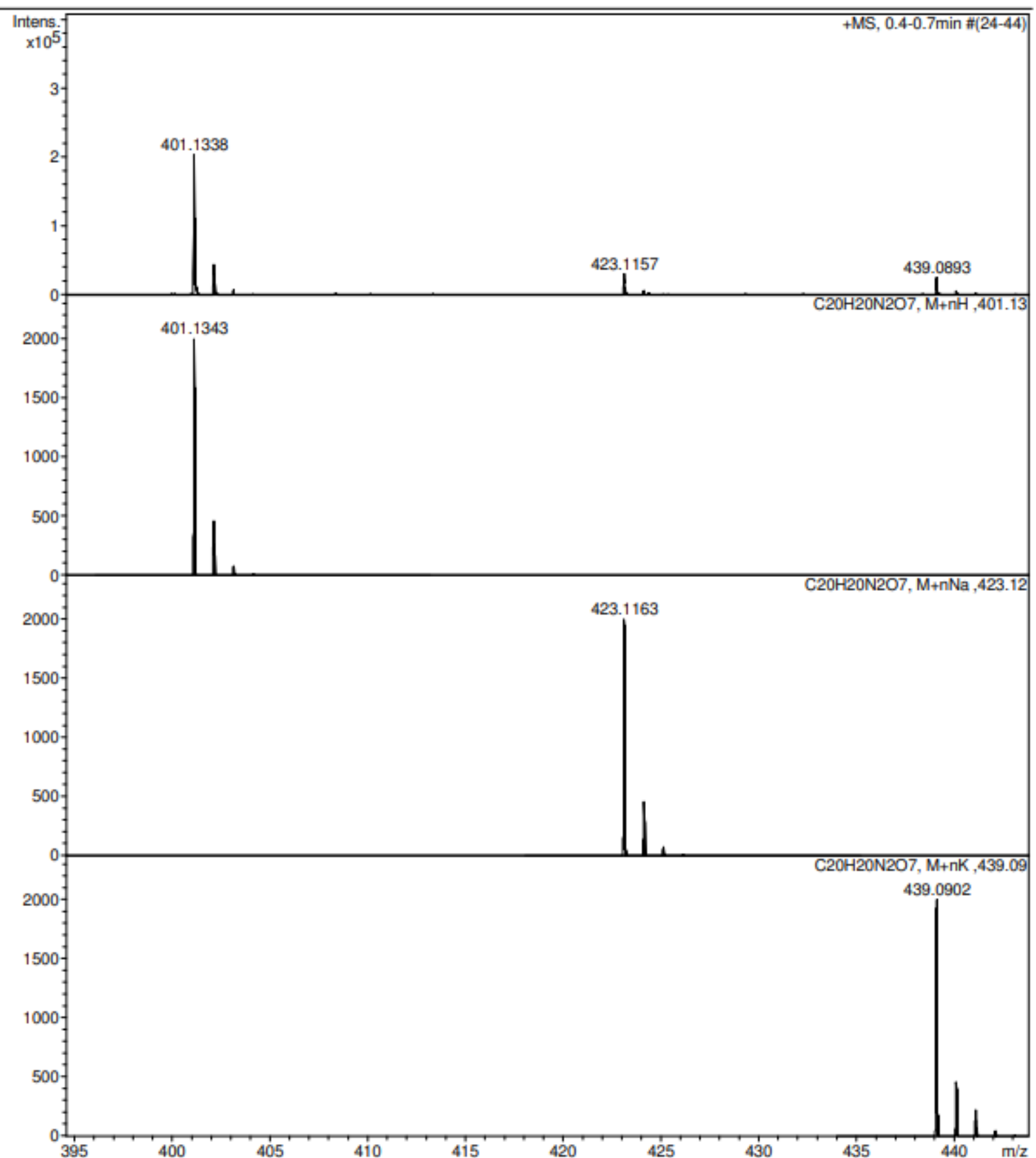


${ }^{1} \mathrm{H}$ NMR spectrum $\left(300 \mathrm{MHz}\right.$ ) of $\mathbf{1 2} \mathbf{f}$ in DMSO- $d_{6}$

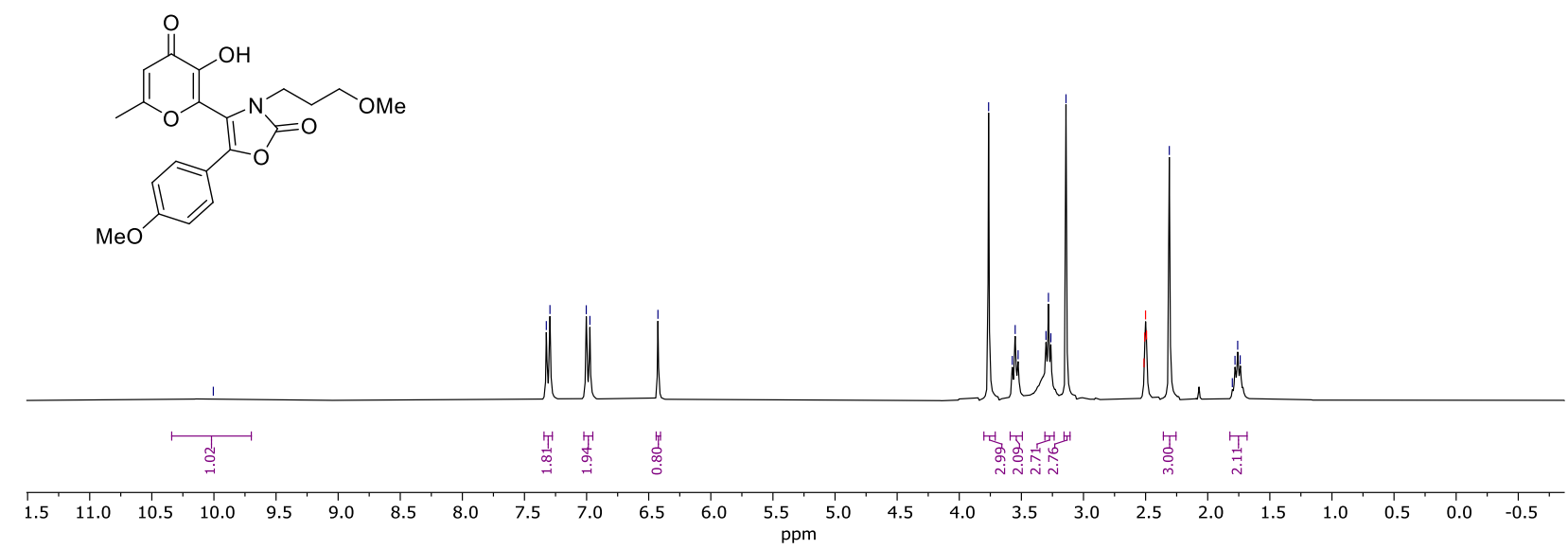

${ }^{13} \mathrm{C}\left\{{ }^{1} \mathrm{H}\right\}$ NMR spectrum (126 MHz) of $\mathbf{1 2 f}$ in DMSO- $d_{6}$

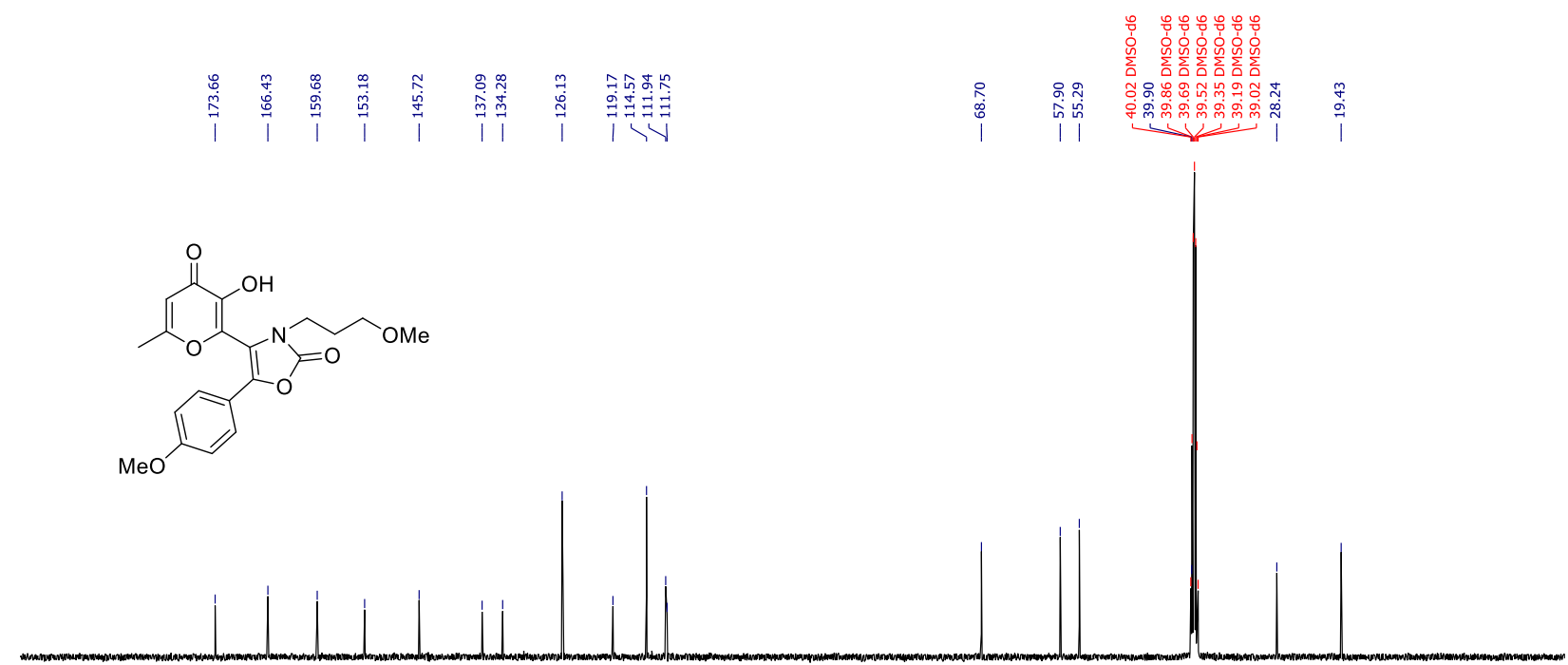

\begin{tabular}{llllllllllllllllllllll}
\hline 00 & 190 & 180 & 170 & 160 & 150 & 140 & 130 & 120 & 110 & 100 & 90 & 80 & 70 & 60 & 50 & 40 & 30 & 20 & 10 & 0 & -1
\end{tabular} 
HRMS for compound $\mathbf{1 2 f}$

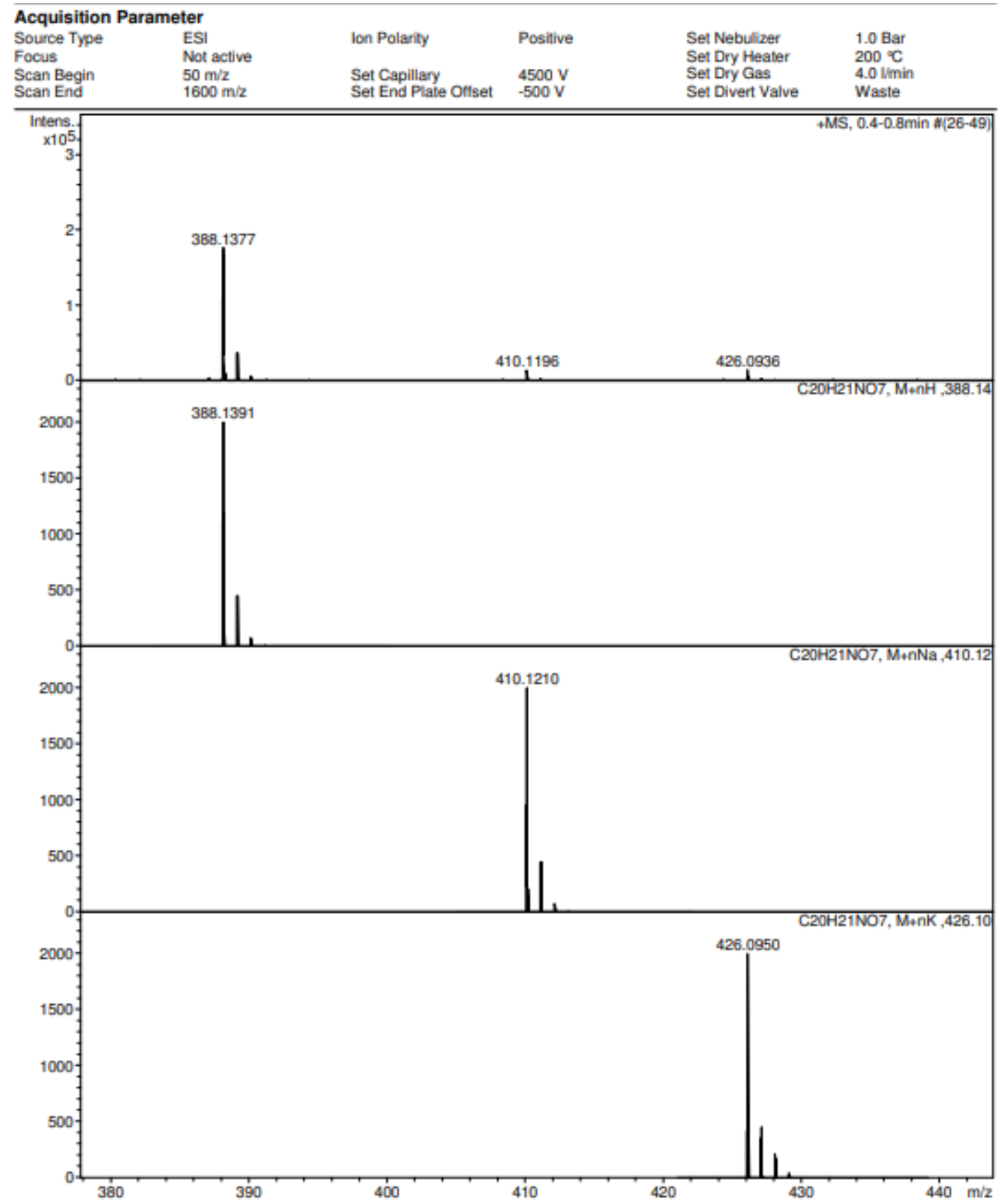


${ }^{1} \mathrm{H}$ NMR spectrum $\left(300 \mathrm{MHz}\right.$ ) of $12 \mathrm{~g}$ in DMSO- $d_{6}$

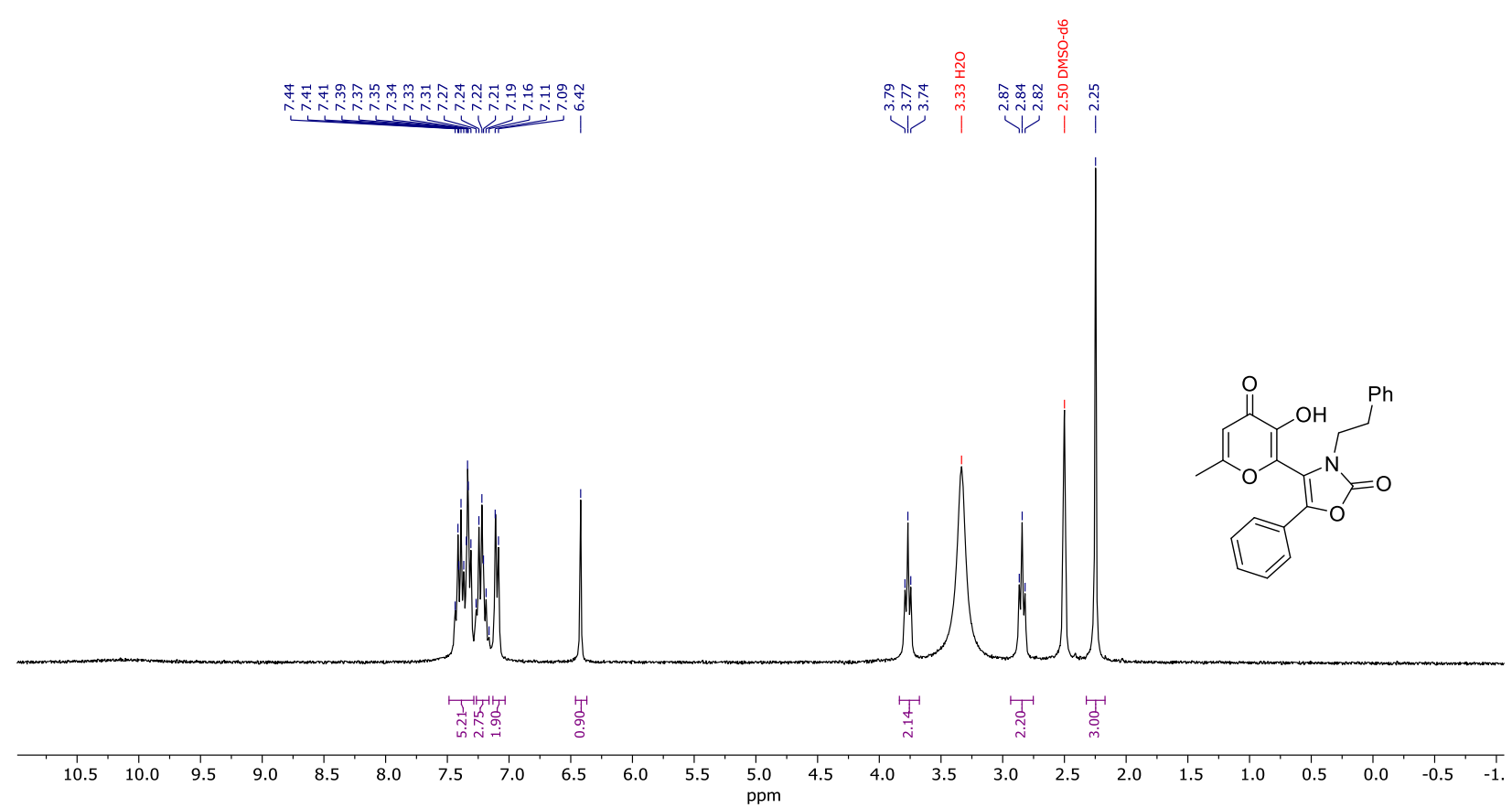

${ }^{13} \mathrm{C}\left\{{ }^{1} \mathrm{H}\right\}$ NMR spectrum (75 MHz) of $12 \mathrm{~g}$ in DMSO- $d_{6}$

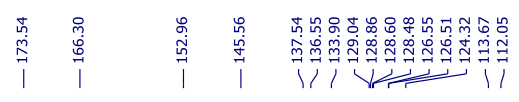
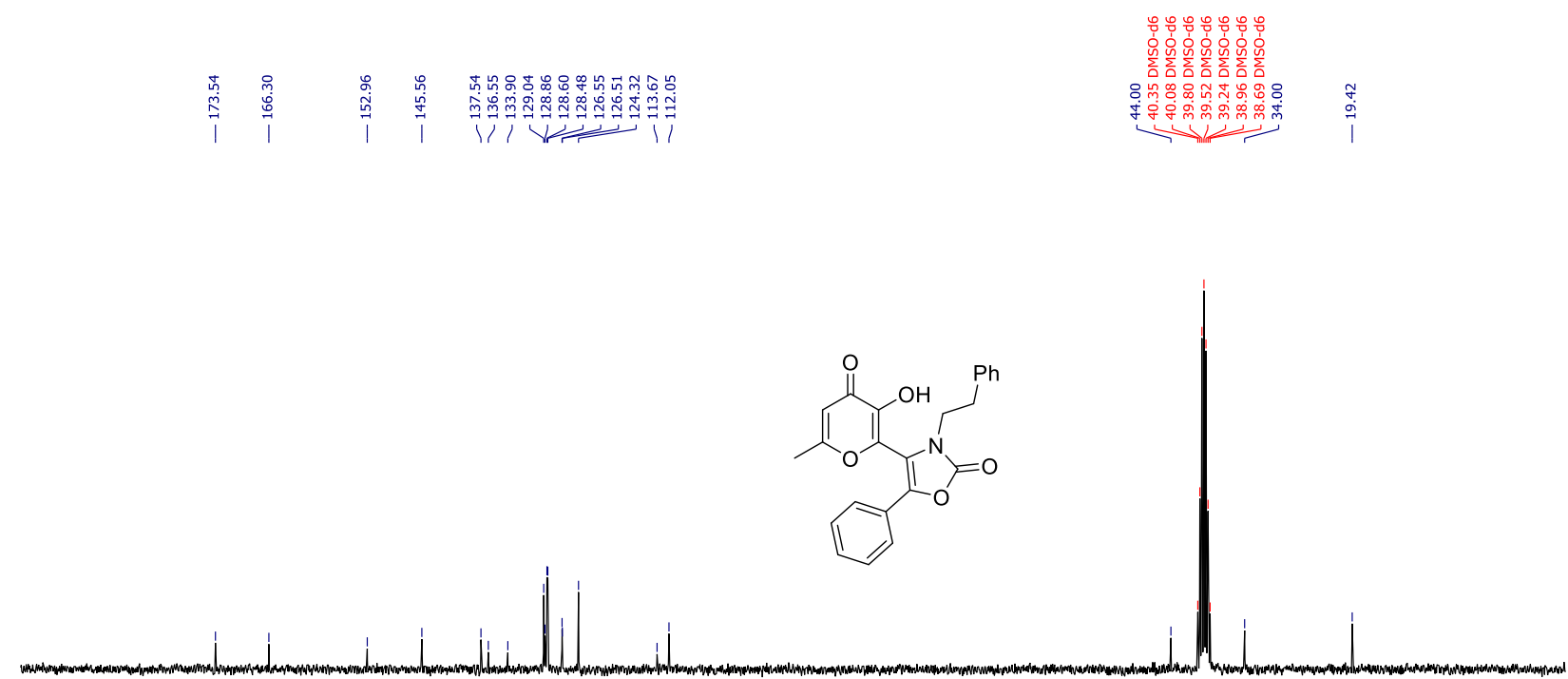

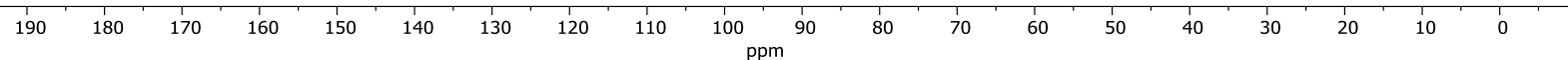


HRMS for compound $\mathbf{1 2 g}$

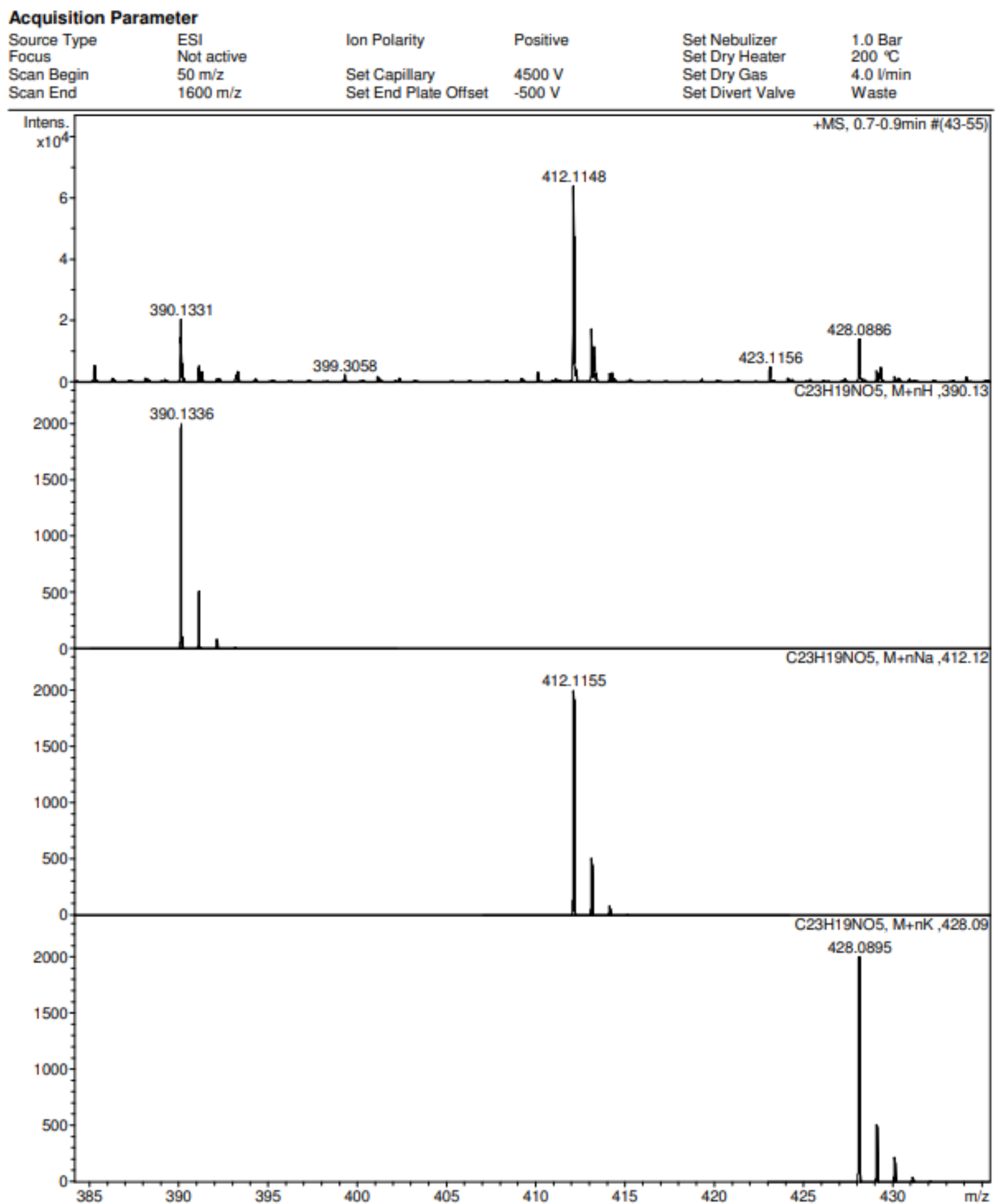


${ }^{1} \mathrm{H}$ NMR spectrum $\left(300 \mathrm{MHz}\right.$ ) of $12 \mathrm{~h}$ in DMSO- $d_{6}$

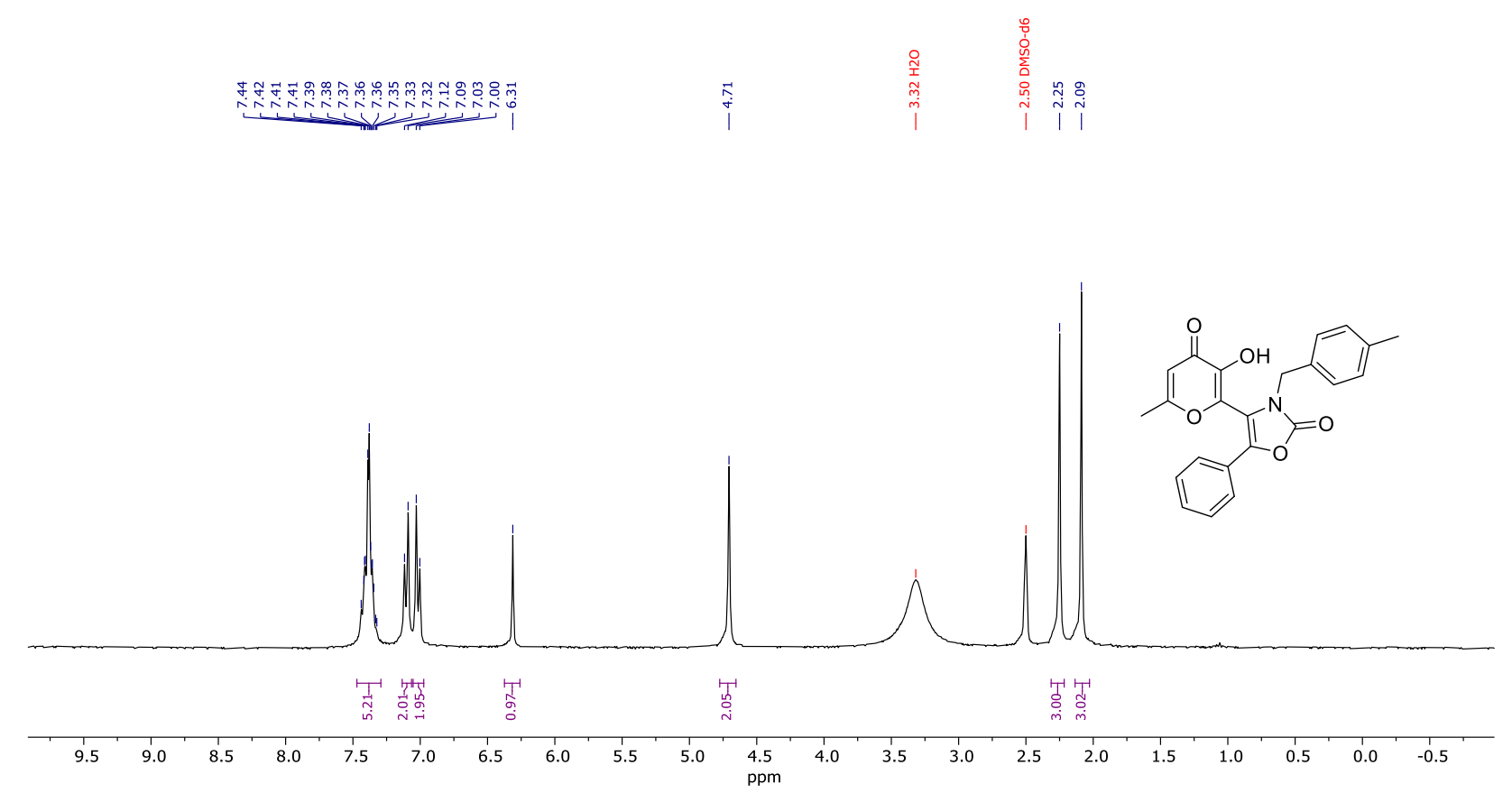

${ }^{13} \mathrm{C}\left\{{ }^{1} \mathrm{H}\right\}$ NMR spectrum $(75 \mathrm{MHz})$ of $12 \mathrm{~h}$ in DMSO- $d_{6}$

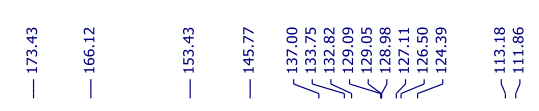
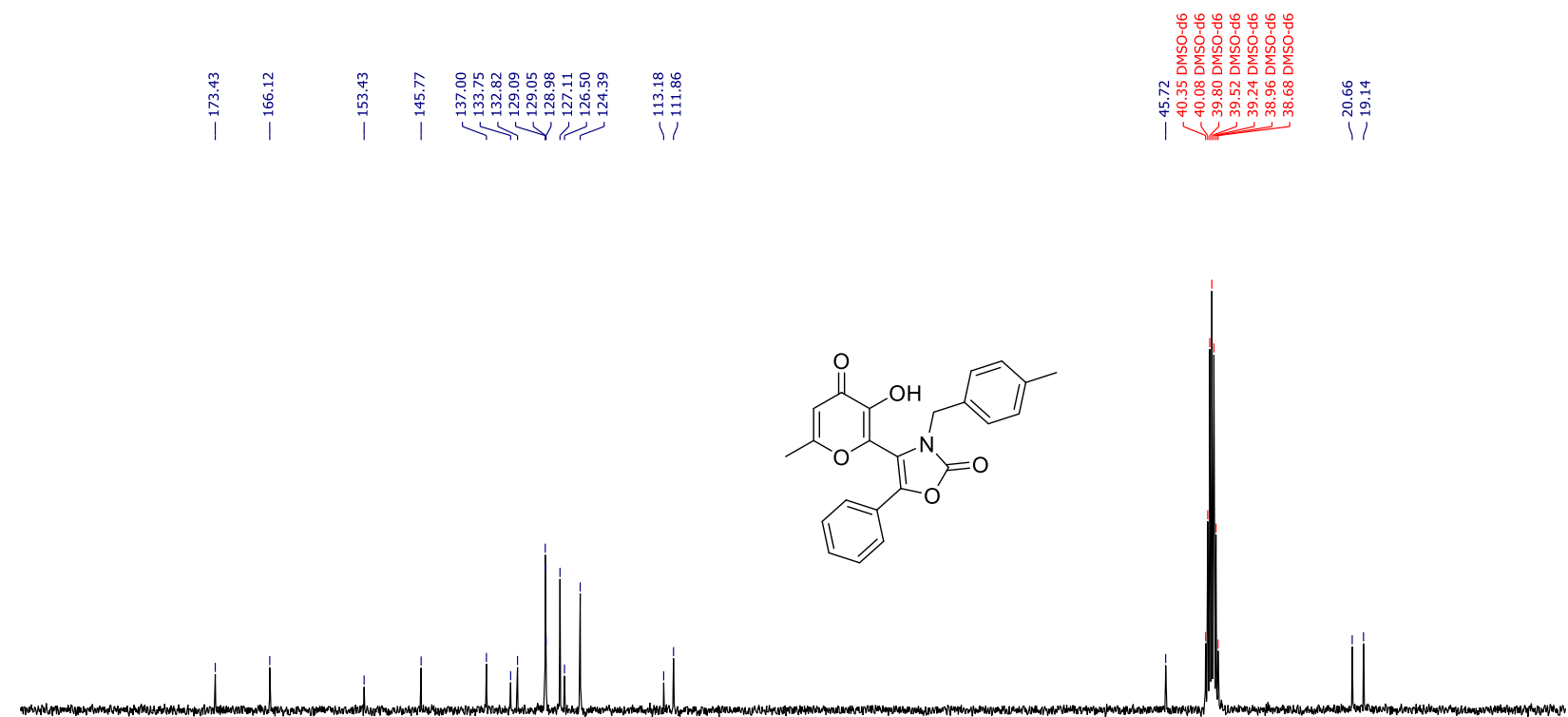

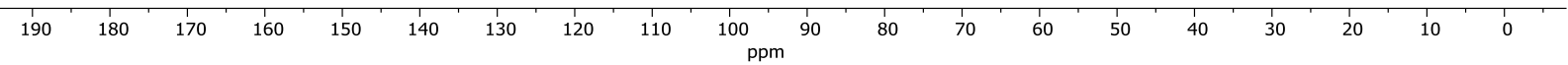


HRMS for compound $\mathbf{1 2 h}$

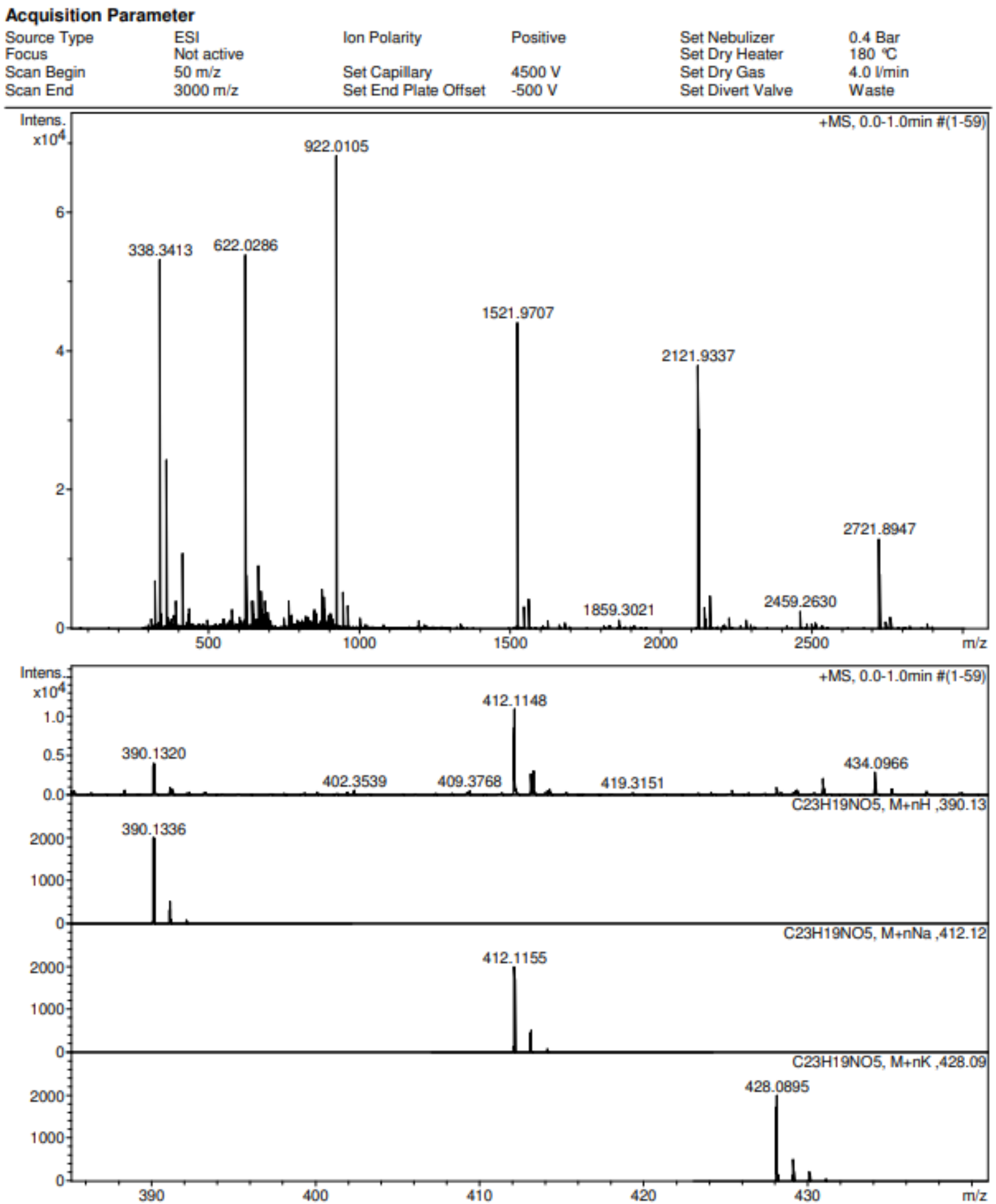


${ }^{1} \mathrm{H}$ NMR spectrum $\left(300 \mathrm{MHz}\right.$ ) of $12 \mathbf{i}$ in DMSO- $d_{6}$

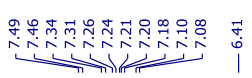

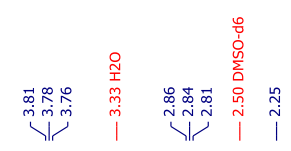

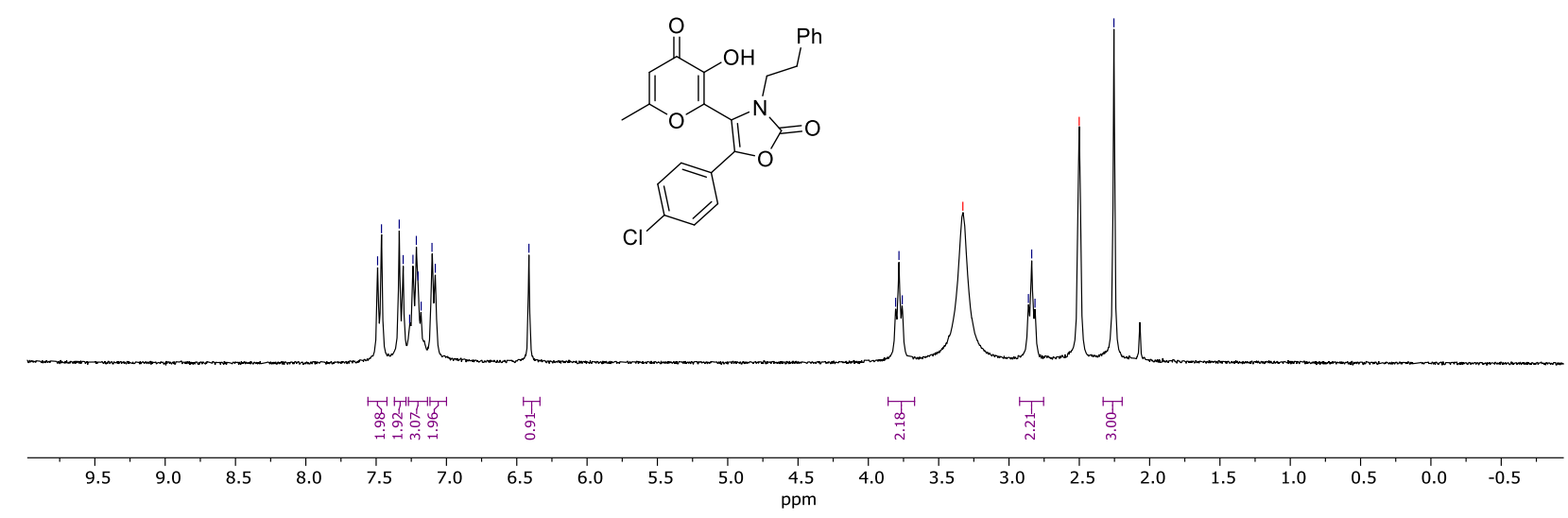

${ }^{13} \mathrm{C}\left\{{ }^{1} \mathrm{H}\right\}$ NMR spectrum $(126 \mathrm{MHz})$ of 12i in DMSO- $d_{6}$

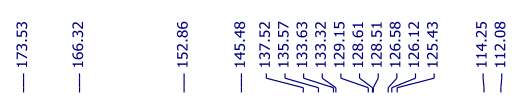

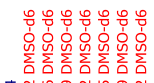

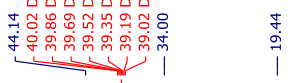
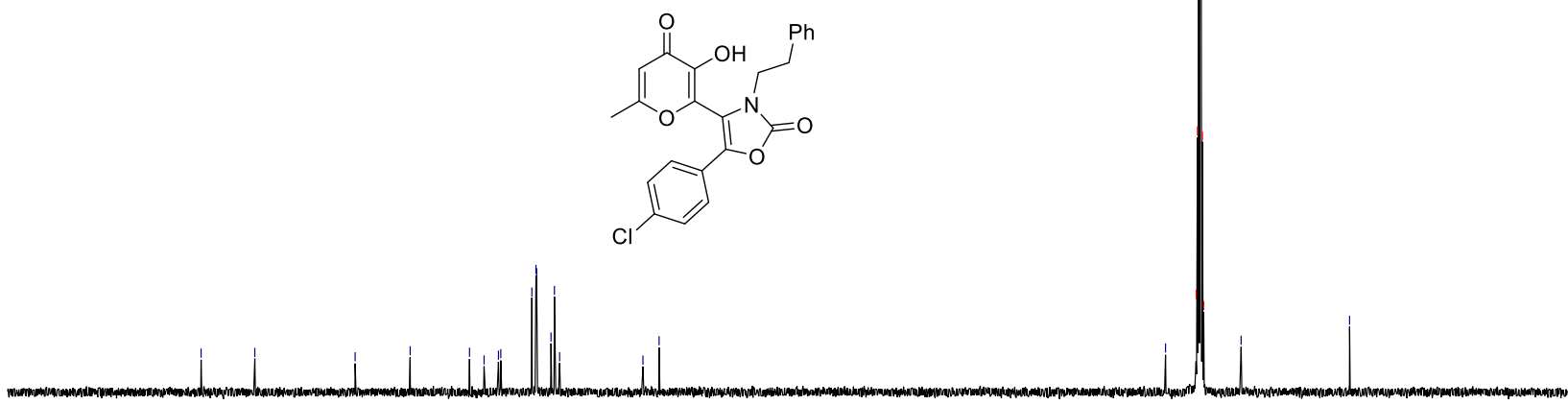

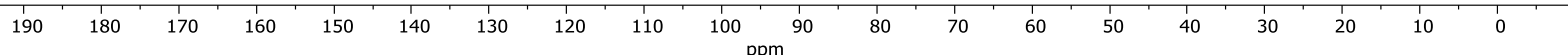


HRMS for compound $\mathbf{1 2} \mathbf{i}$

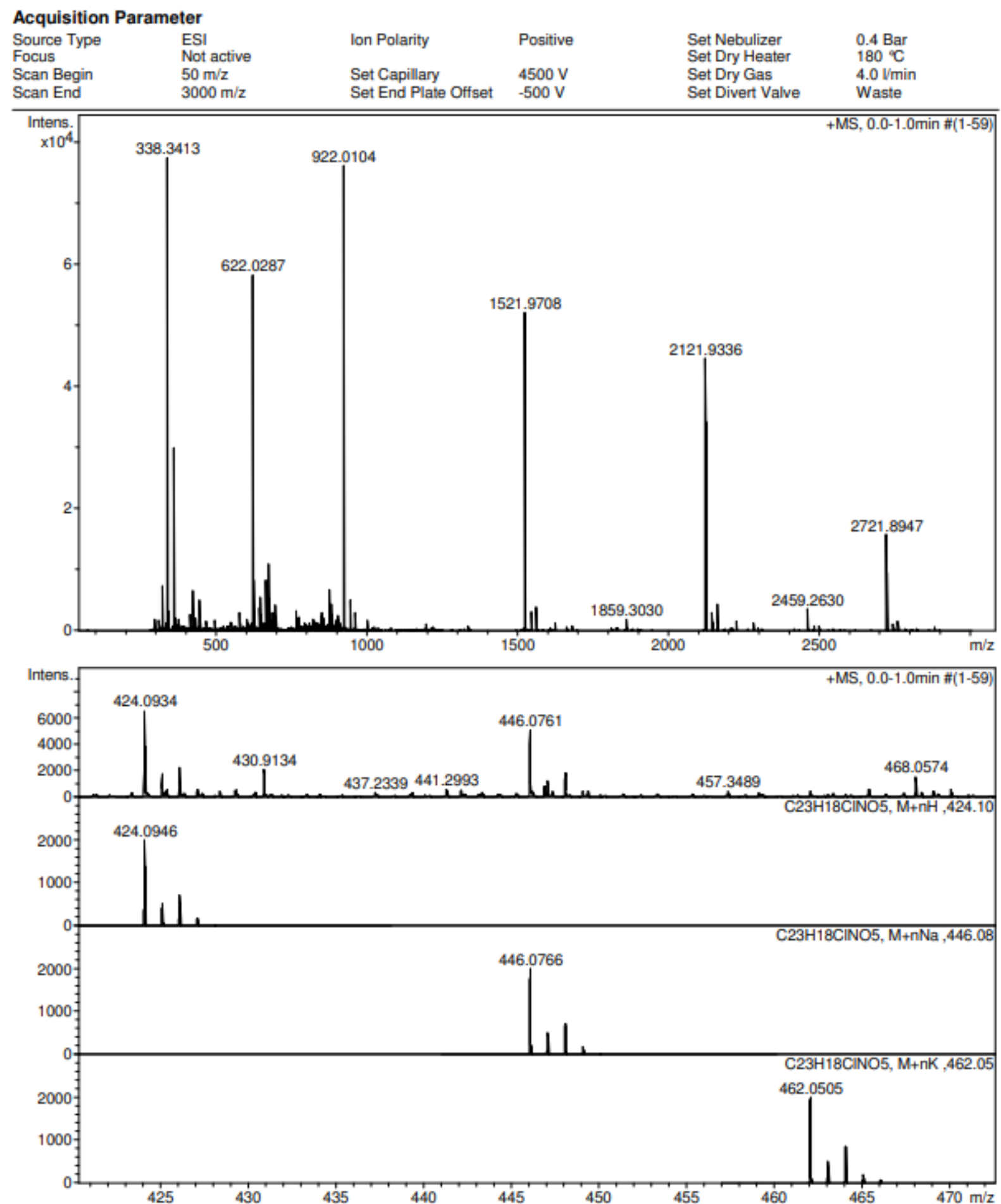


${ }^{1} \mathrm{H}$ NMR spectrum (300 MHz) of $12 \mathrm{j}$ in DMSO- $d_{6}$

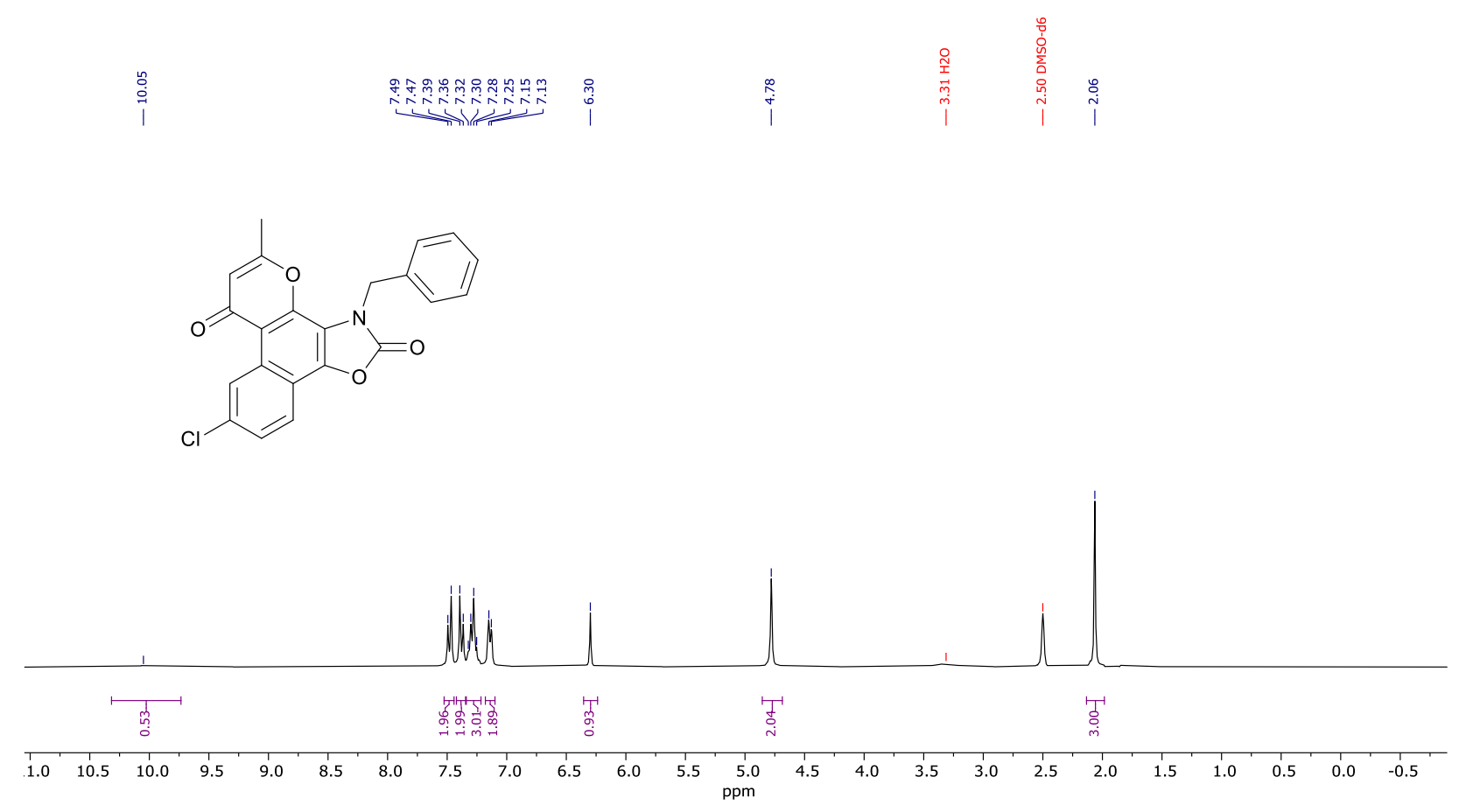

${ }^{13} \mathrm{C}\left\{{ }^{1} \mathrm{H}\right\}$ NMR spectrum $(75 \mathrm{MHz})$ of $\mathbf{1 2} \mathbf{j}$ in DMSO- $d_{6}$

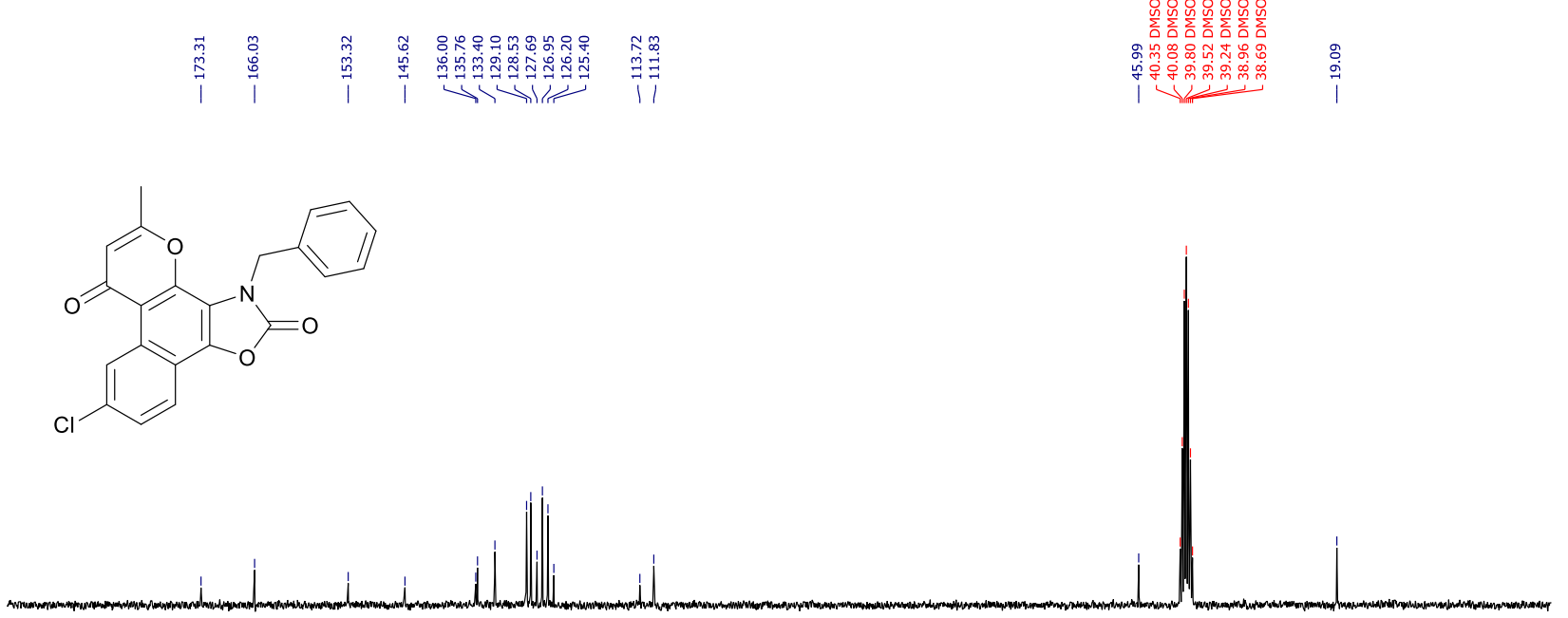

\begin{tabular}{llllllllllllllllllllll}
\hline 190 & 180 & 170 & 160 & 150 & 140 & 130 & 120 & 110 & 100 & 90 & 80 & 70 & 60 & 50 & 40 & 30 & 20 & 10 & 0 & -1
\end{tabular} 
HRMS for compound $\mathbf{1 2} \mathbf{j}$

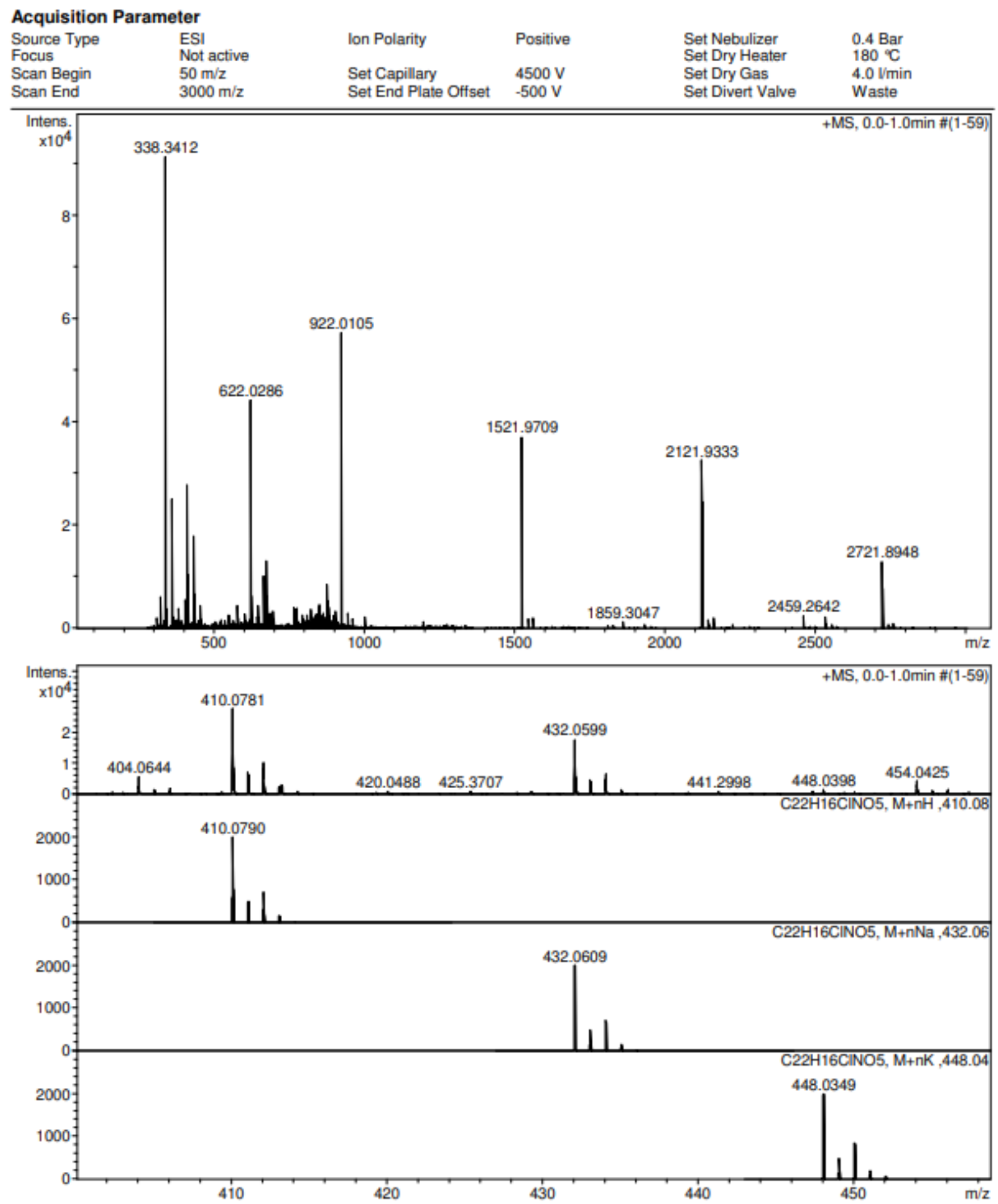


${ }^{1} \mathrm{H}$ NMR spectrum (300 MHz) of $\mathbf{1 2} \mathbf{k}$ in DMSO- $d_{6}$

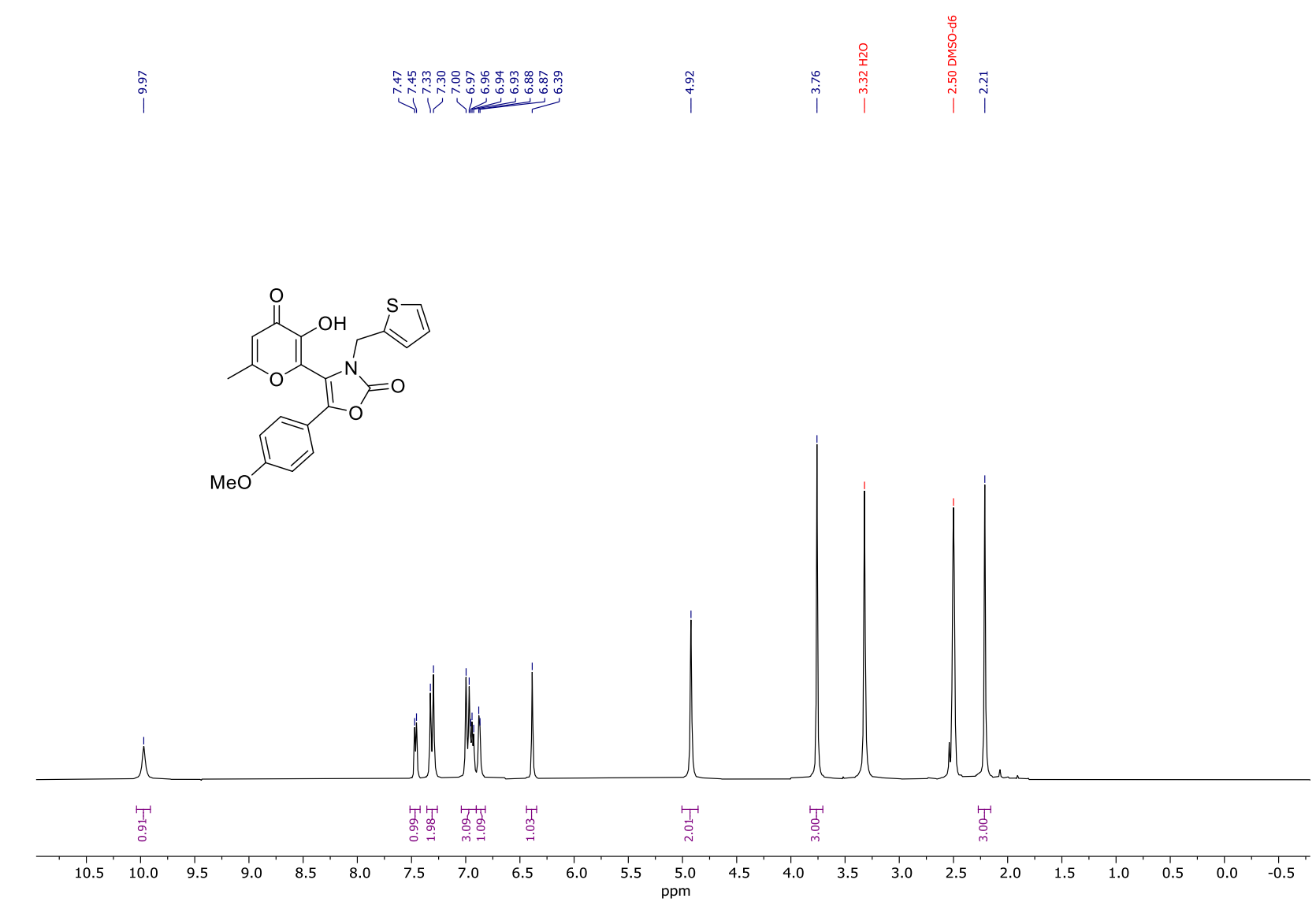

${ }^{13} \mathrm{C}\left\{{ }^{1} \mathrm{H}\right\}$ NMR spectrum $\left(75 \mathrm{MHz}\right.$ ) of $\mathbf{1 2 k}$ in DMSO- $d_{6}$

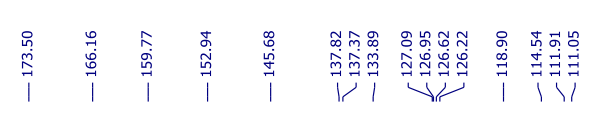
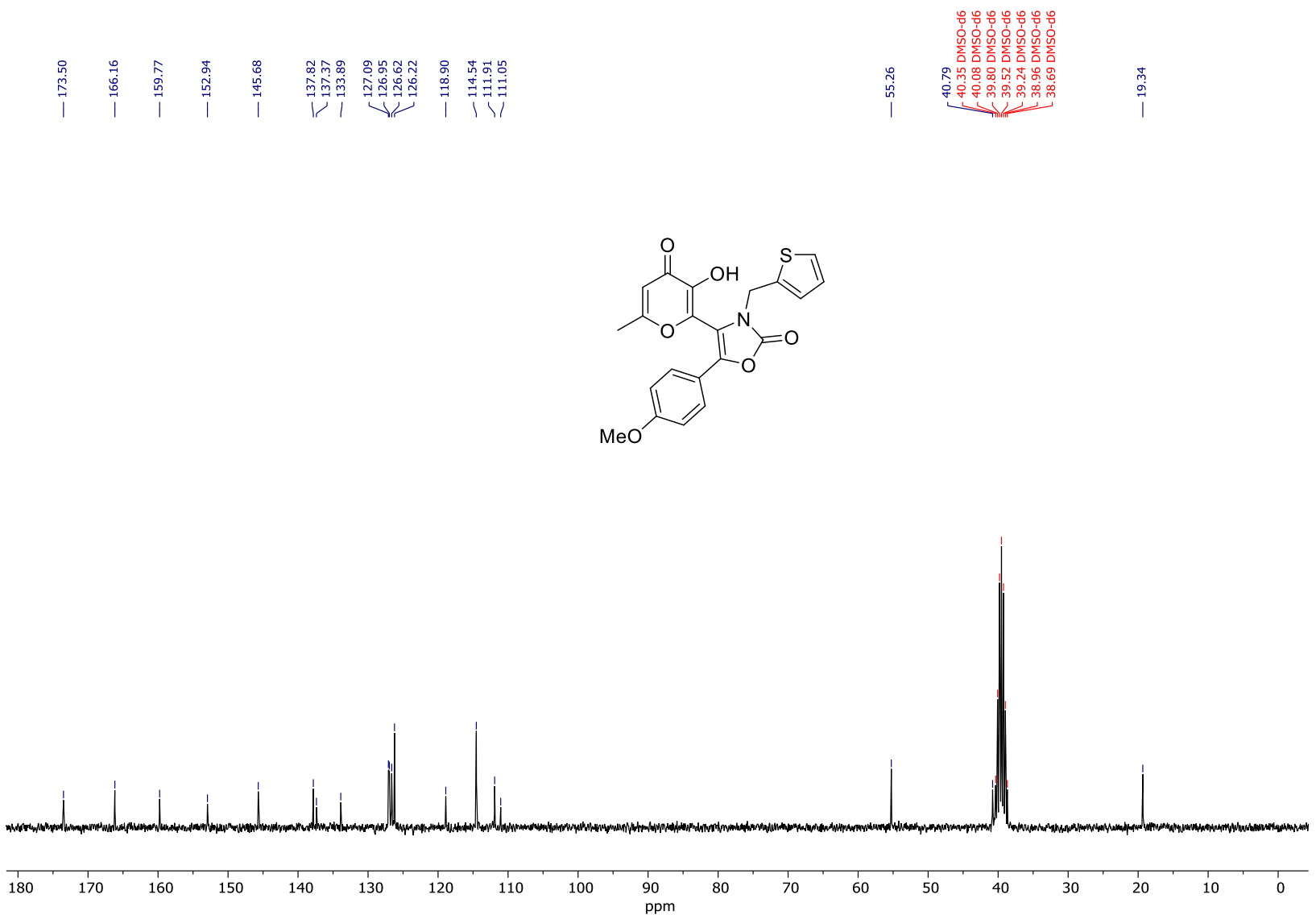
HRMS for compound $\mathbf{1 2 k}$

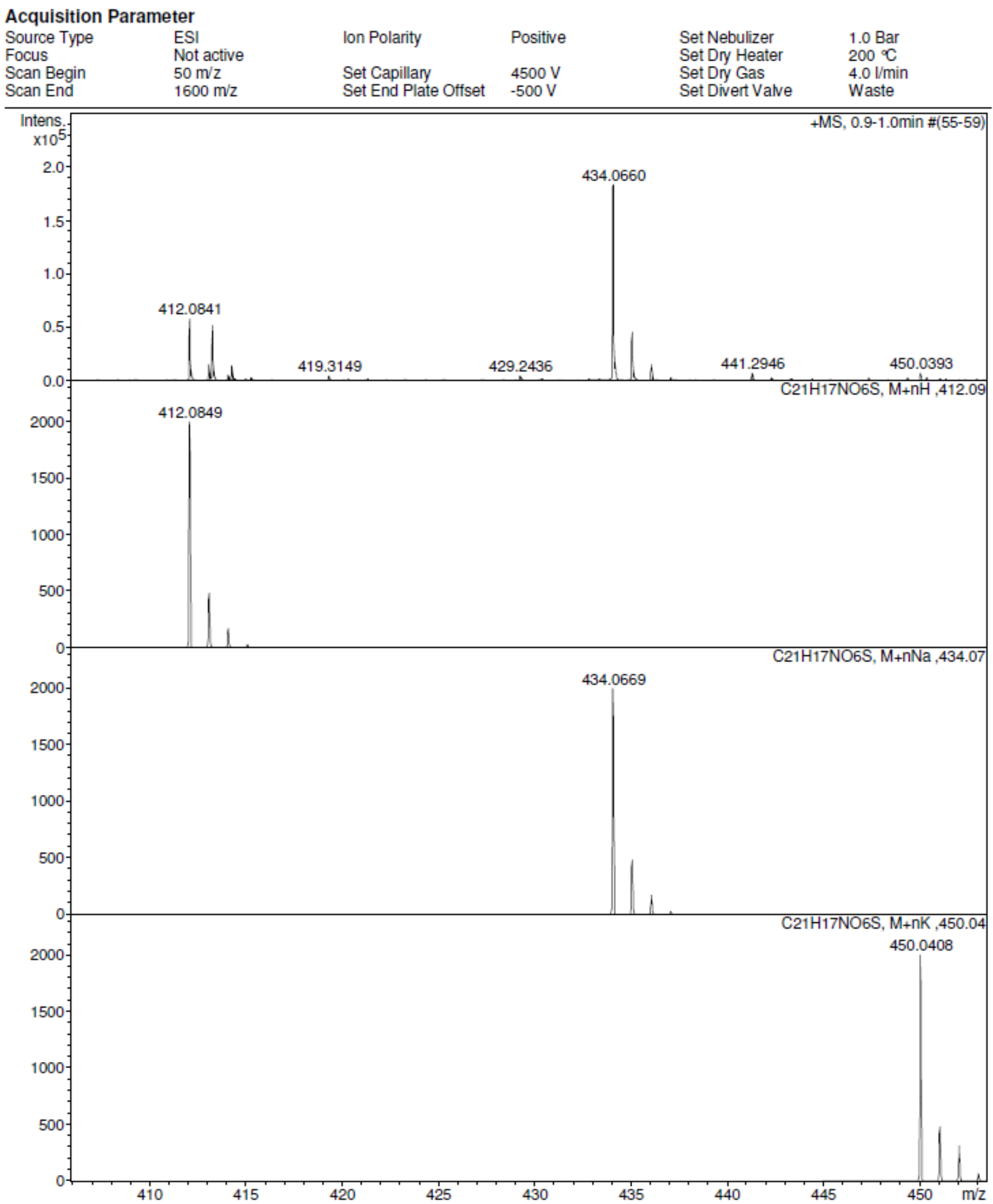


5. Copies of ${ }^{1} \mathrm{H},{ }^{13} \mathrm{C}$ NMR and HRMS spectra for compounds $\mathbf{1 4}$.

${ }^{1} \mathrm{H}$ NMR spectrum (300 MHz) of 14 a in DMSO- $d_{6}$
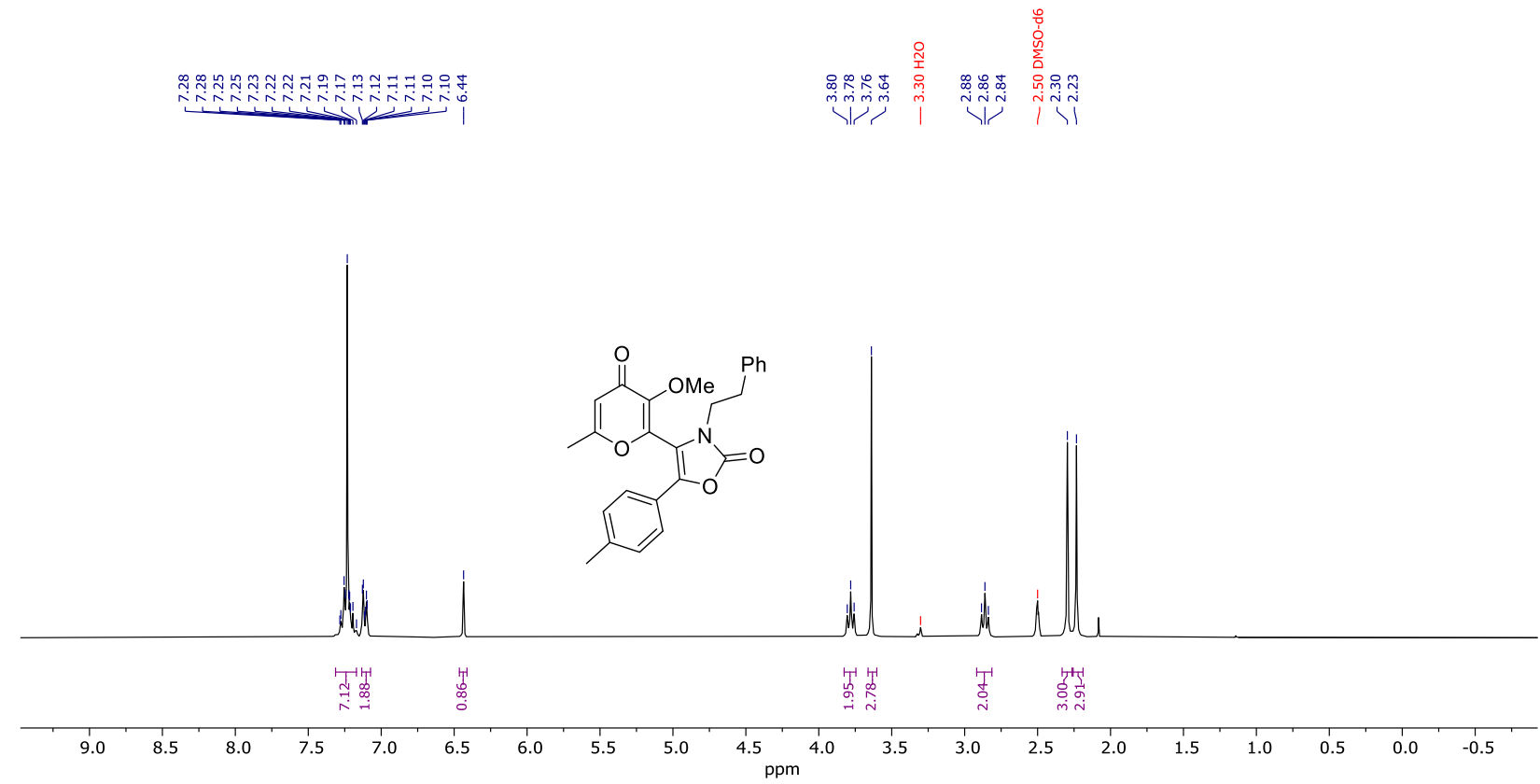

${ }^{13} \mathrm{C}\left\{{ }^{1} \mathrm{H}\right\}$ NMR spectrum (126 MHz) of $14 \mathrm{a}$ in DMSO- $d_{6}$

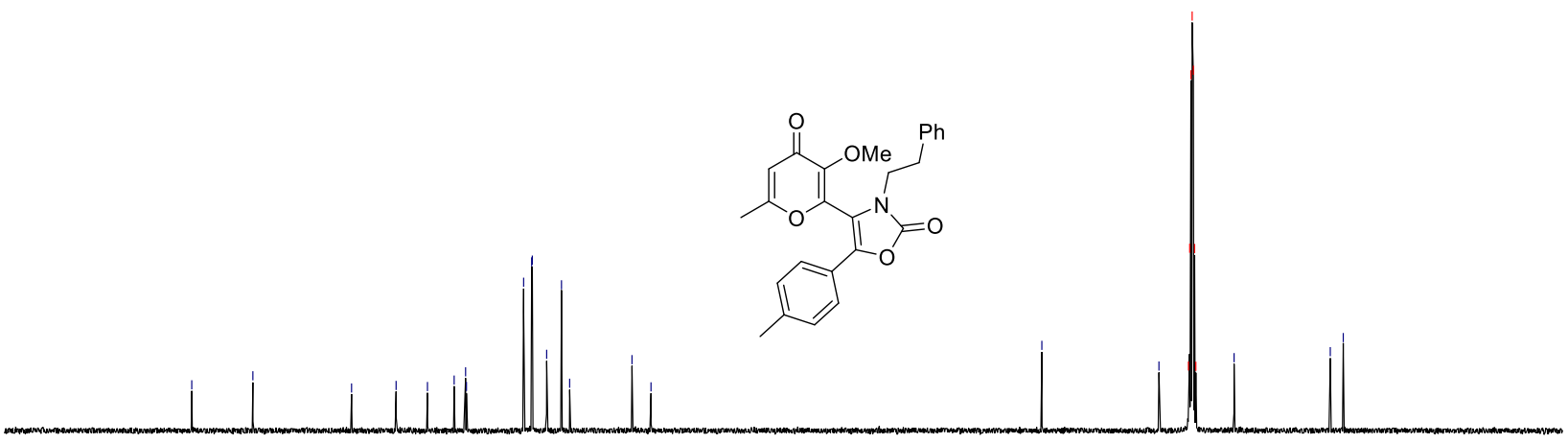


HRMS for compound $\mathbf{1 4 a}$

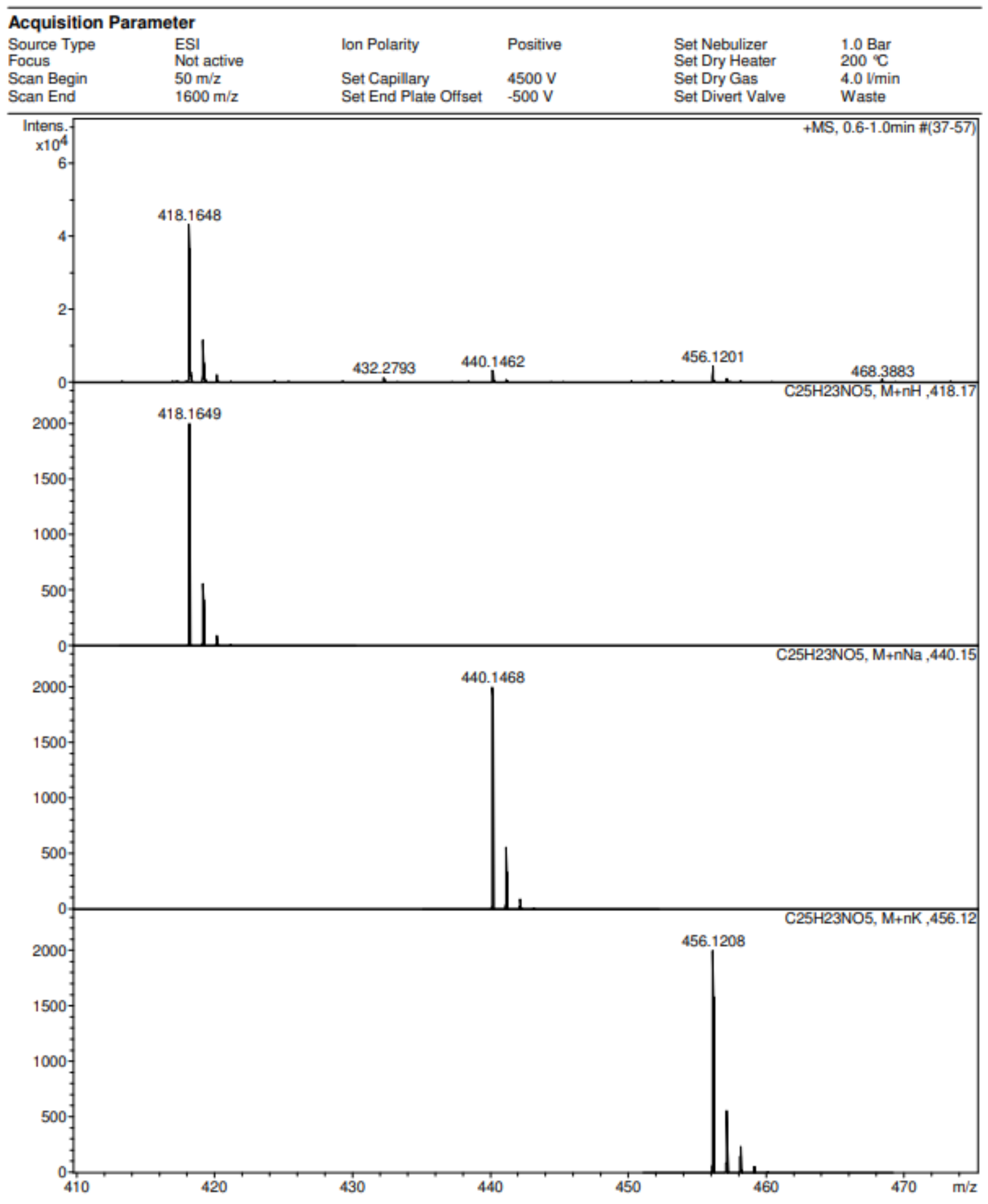


${ }^{1} \mathrm{H}$ NMR spectrum $\left(300 \mathrm{MHz}\right.$ ) of $14 \mathbf{b}$ in DMSO- $d_{6}$

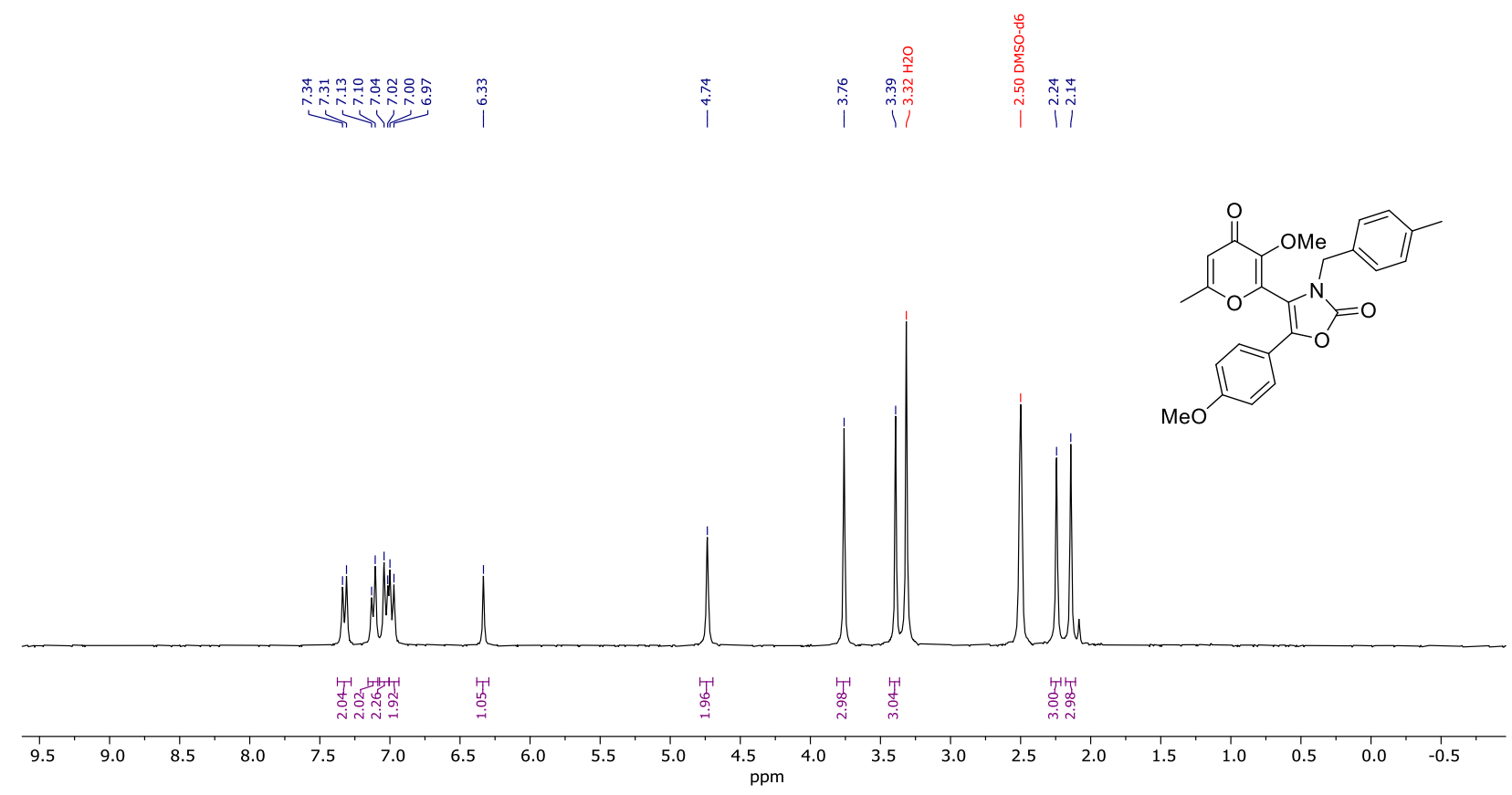

${ }^{13} \mathrm{C}\left\{{ }^{1} \mathrm{H}\right\}$ NMR spectrum (126 MHz) of 14b in DMSO- $d_{6}$

$$
\text { H H H H }
$$

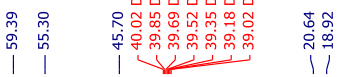

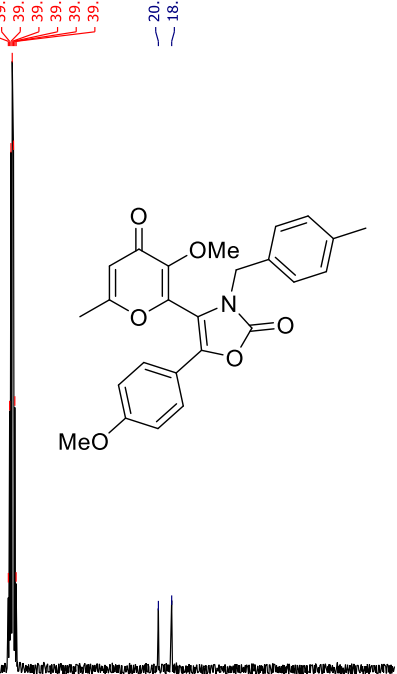

$\begin{array}{rrrr}170 & 160 & 150 & 140\end{array}$

ppm 
HRMS for compound $\mathbf{1 4 b}$
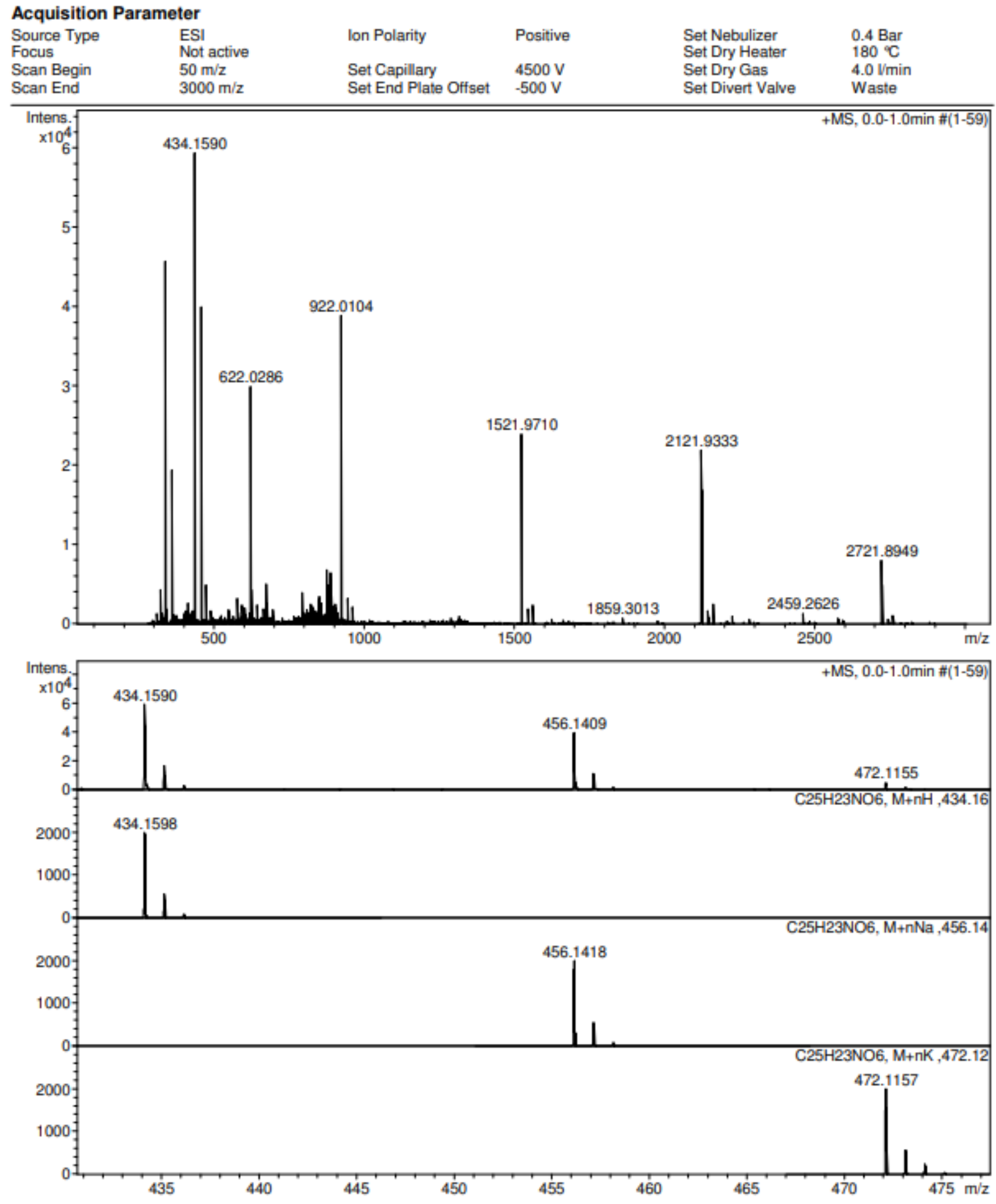
${ }^{1} \mathrm{H}$ NMR spectrum $(300 \mathrm{MHz})$ of $14 \mathrm{c}$ in DMSO- $d_{6}$

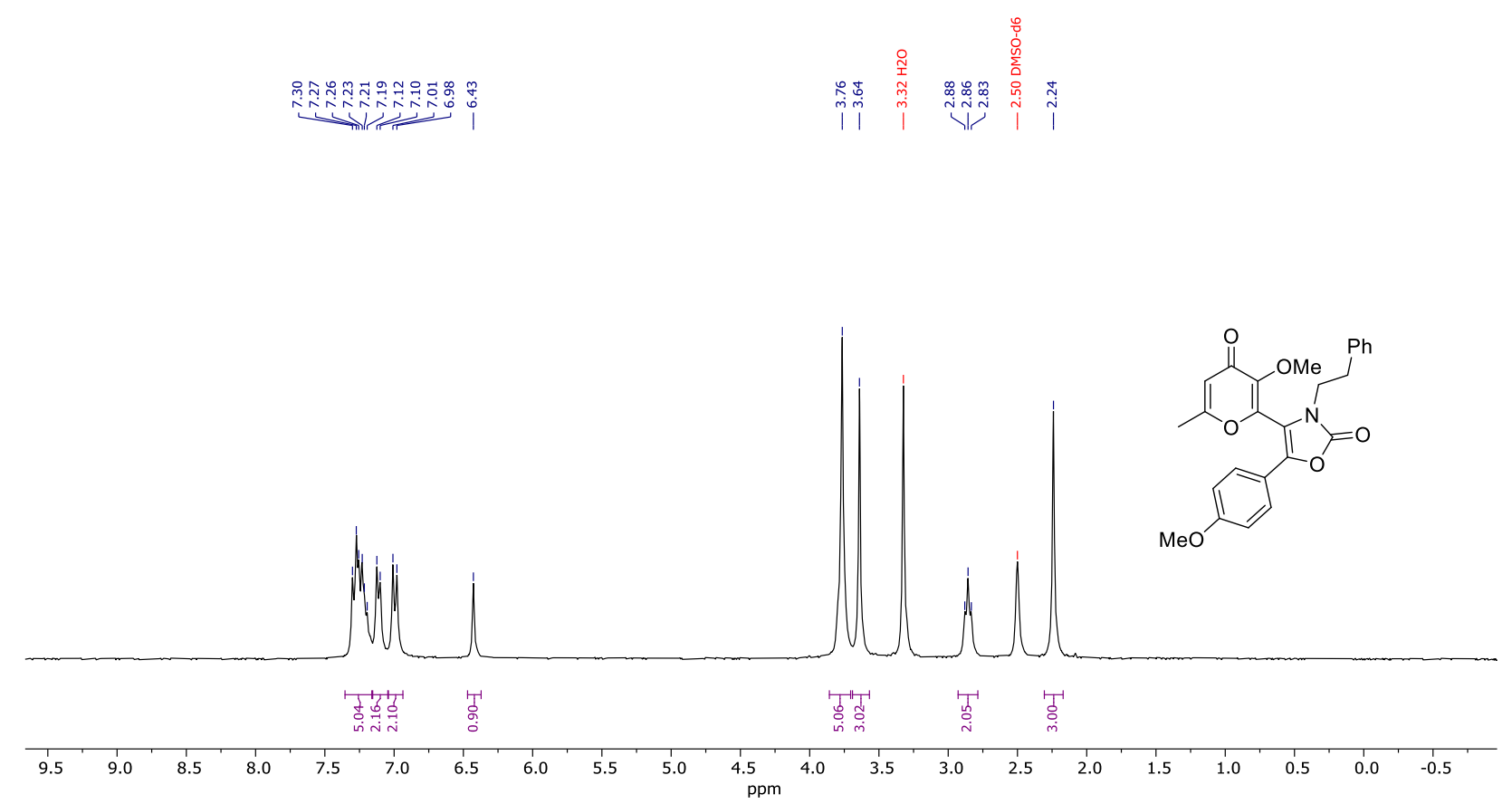

${ }^{13} \mathrm{C}\left\{{ }^{1} \mathrm{H}\right\}$ NMR spectrum $(126 \mathrm{MHz})$ of $14 \mathrm{c}$ in DMSO- $d_{6}$

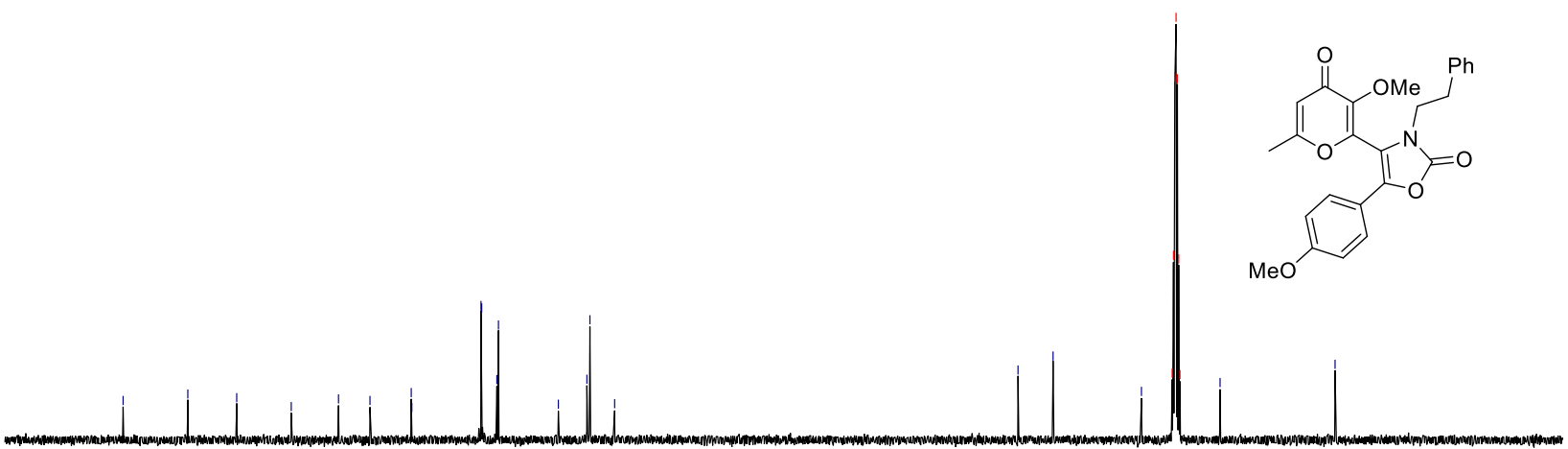

$\begin{array}{lllllllllllllllllll}180 & 170 & 160 & 150 & 140 & 130 & 120 & 110 & 100 & 90 & 80 & 70 & 60 & 50 & 40 & 30 & 20 & 10 & 0\end{array}$ 
HRMS for compound 14c

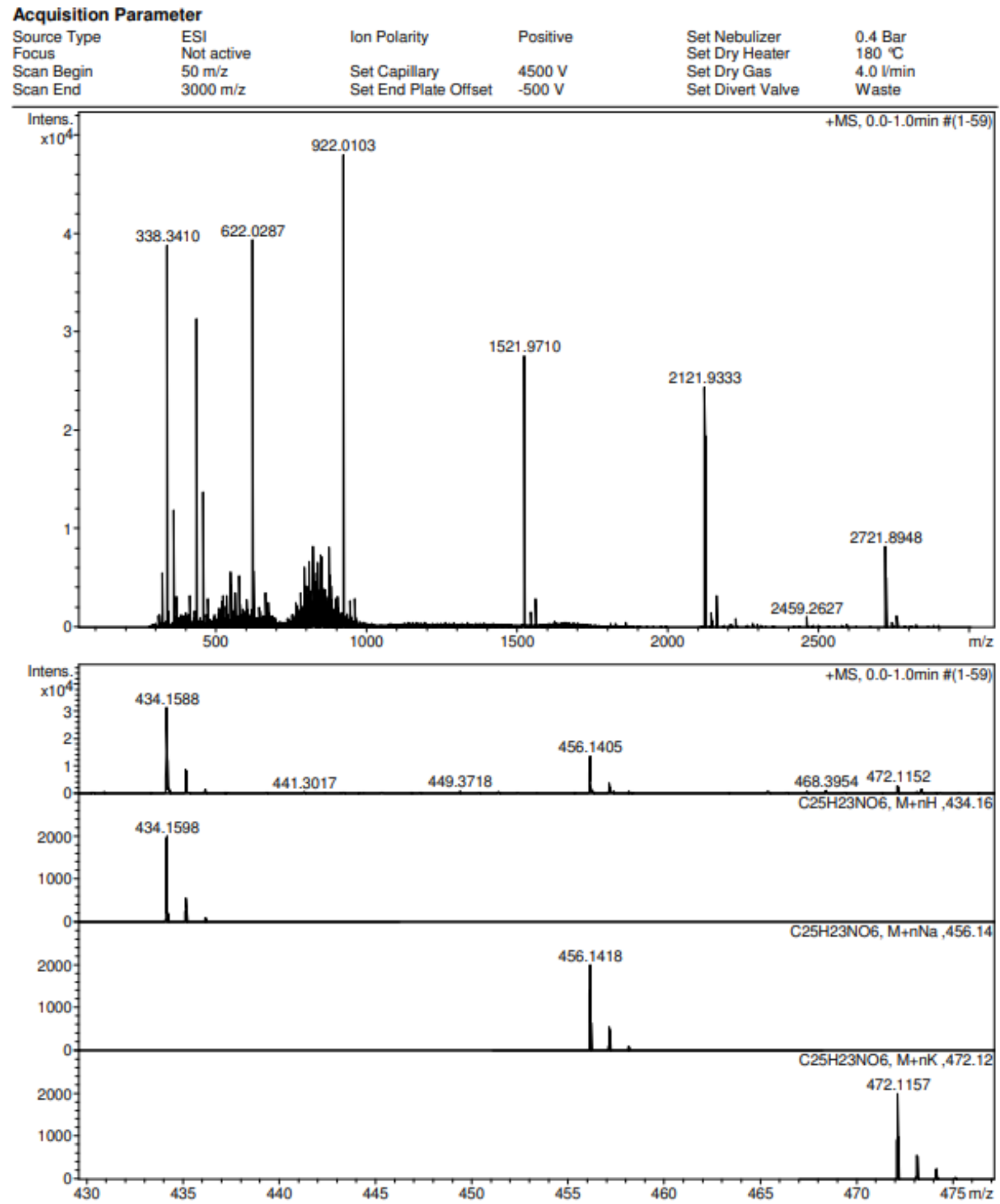


${ }^{1} \mathrm{H}$ NMR spectrum $\left(300 \mathrm{MHz}\right.$ ) of $14 \mathrm{~d}$ in DMSO- $d_{6}$

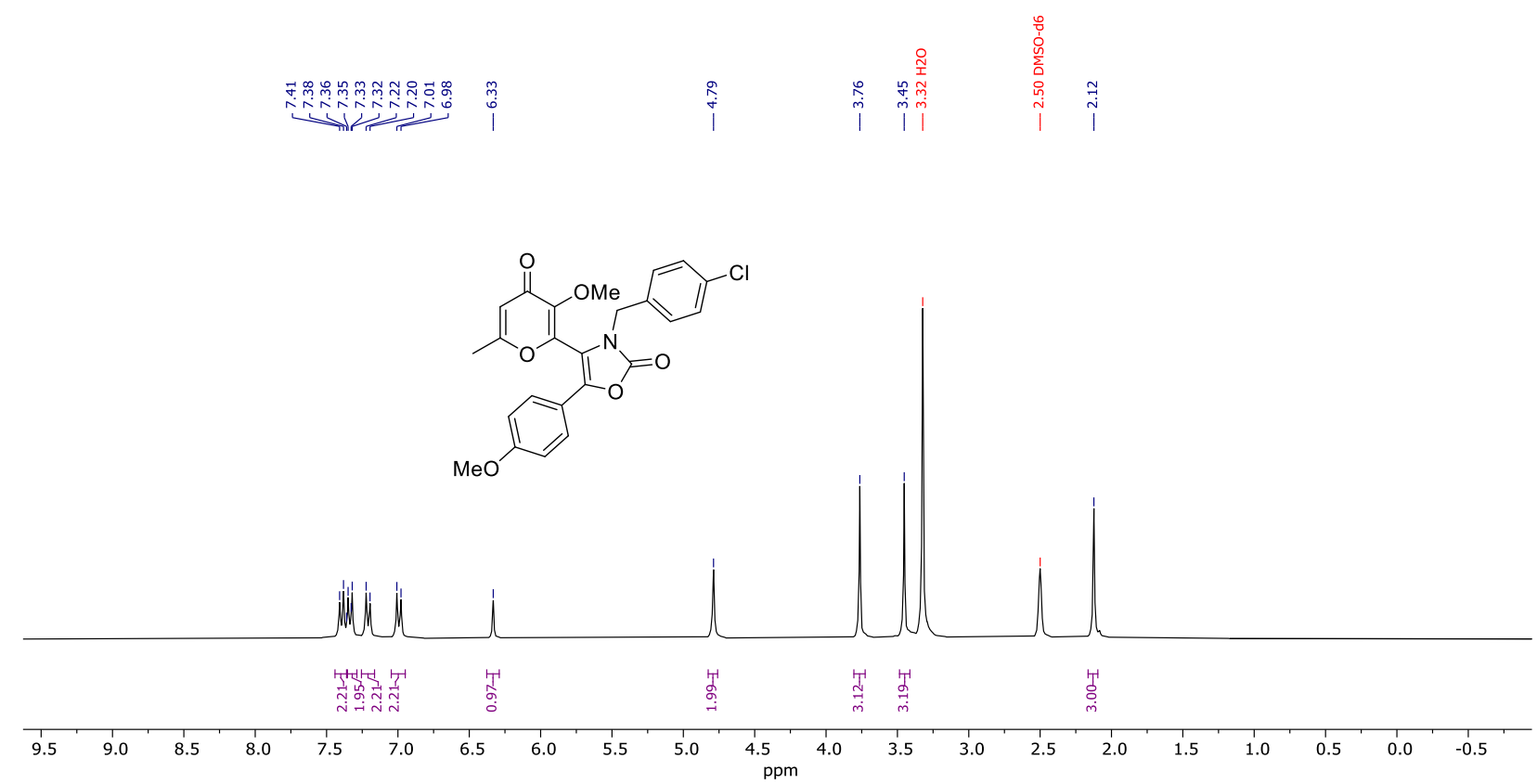

${ }^{13} \mathrm{C}\left\{{ }^{1} \mathrm{H}\right\}$ NMR spectrum (126 MHz) of $14 \mathbf{d}$ in DMSO- $d_{6}$

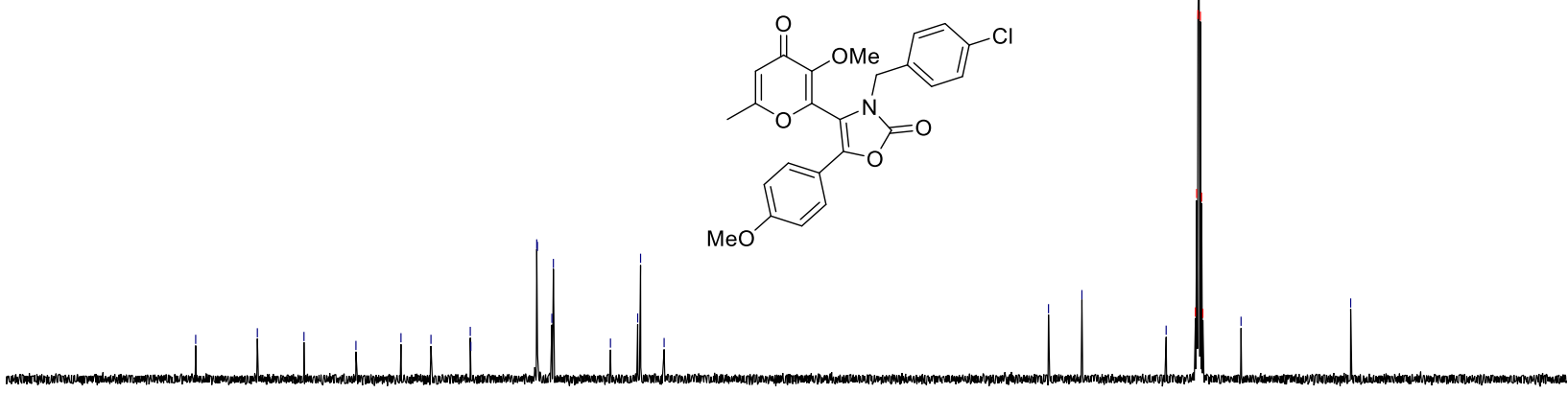


HRMS for compound 14d

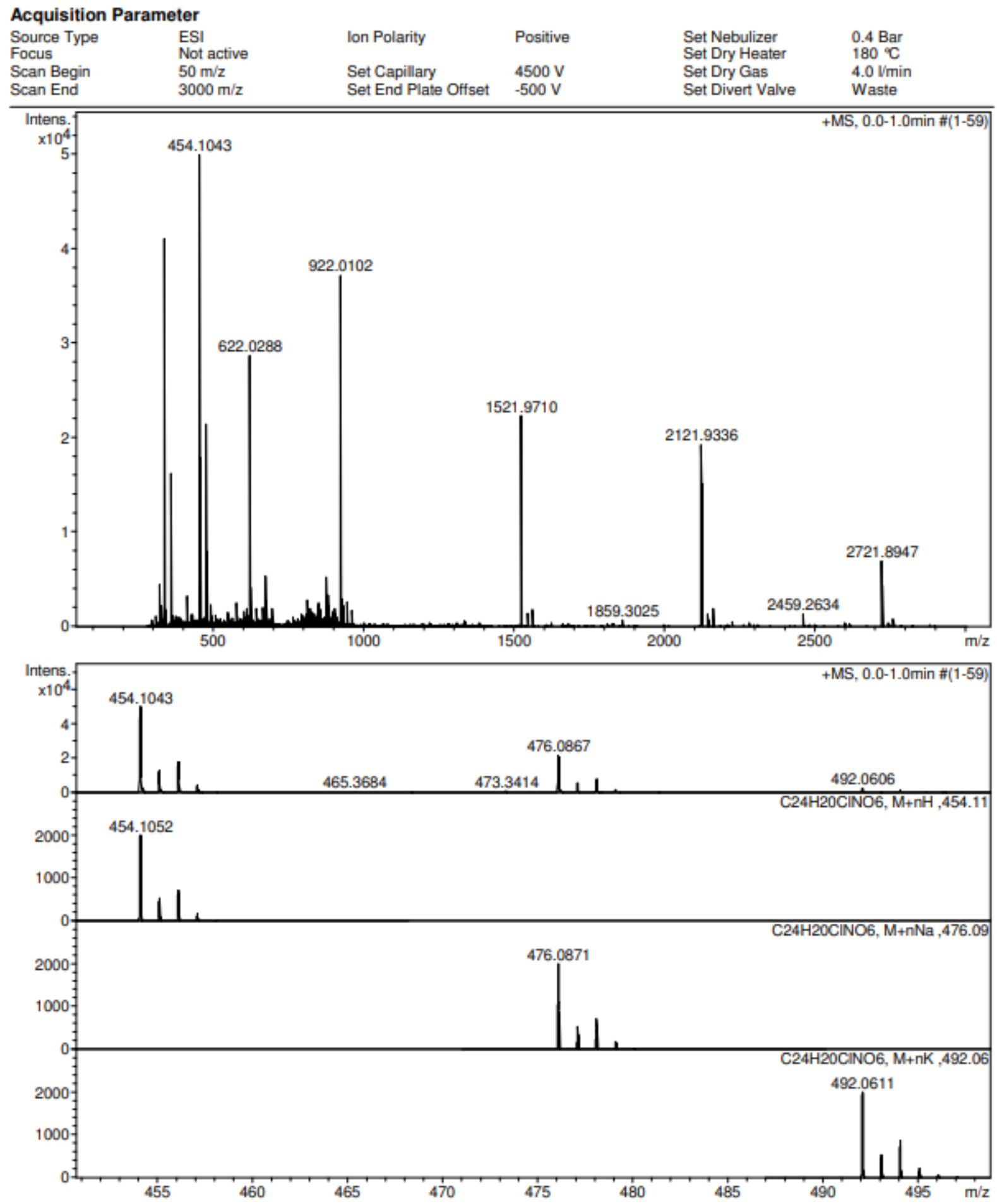


${ }^{1} \mathrm{H}$ NMR spectrum $\left(300 \mathrm{MHz}\right.$ ) of $14 \mathrm{e}$ in DMSO- $d_{6}$

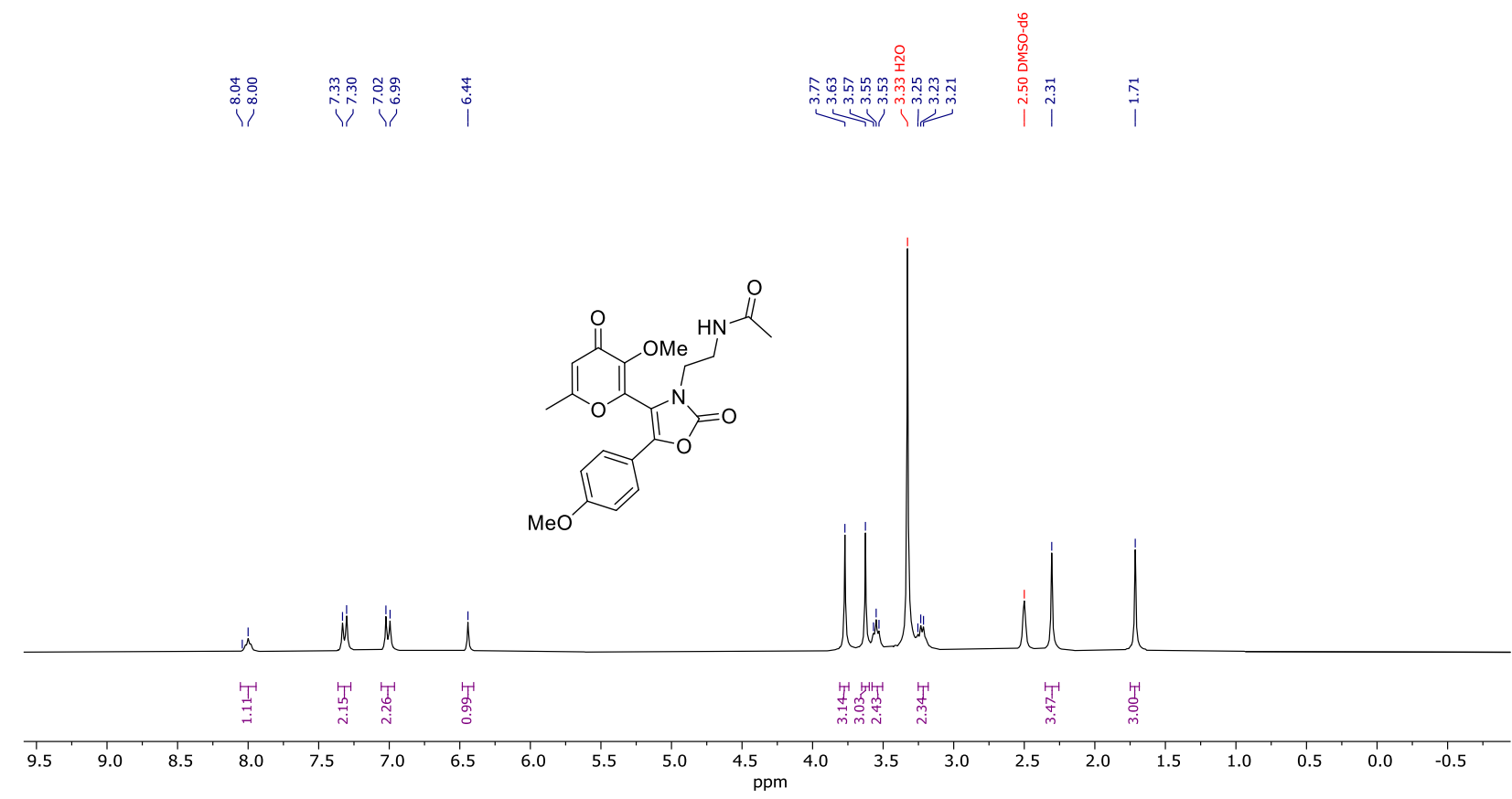

${ }^{13} \mathrm{C}\left\{{ }^{1} \mathrm{H}\right\}$ NMR spectrum $(126 \mathrm{MHz})$ of $14 \mathrm{e}$ in DMSO-d

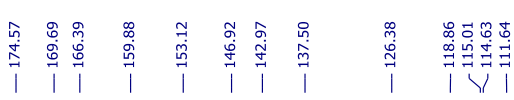

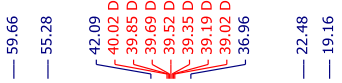
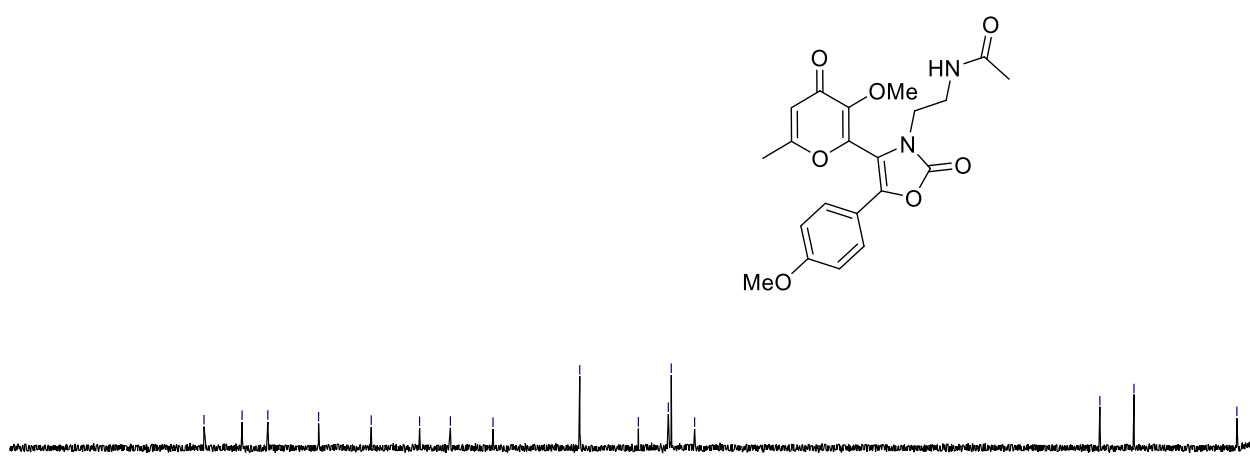

$\begin{array}{llllllllllllllllllll}190 & 180 & 170 & 160 & 150 & 140 & 130 & 120 & 110 & 100 & 90 & 80 & 70 & 60 & 50 & 40 & 30 & 20 & 10 & 0\end{array}$ 
HRMS for compound $14 e$
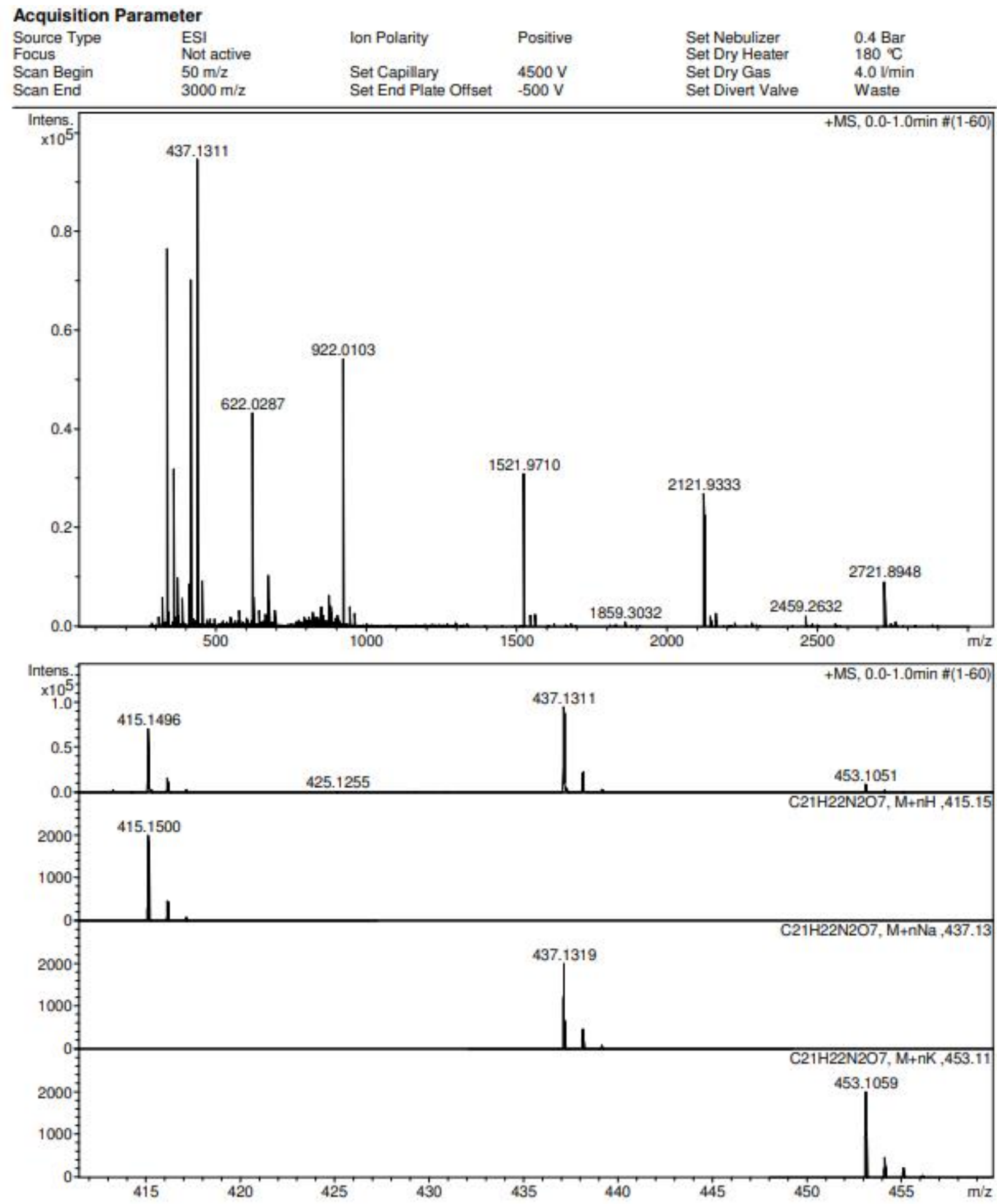
${ }^{1} \mathrm{H}$ NMR spectrum (300 MHz) of $14 \mathrm{f}$ in DMSO- $d_{6}$

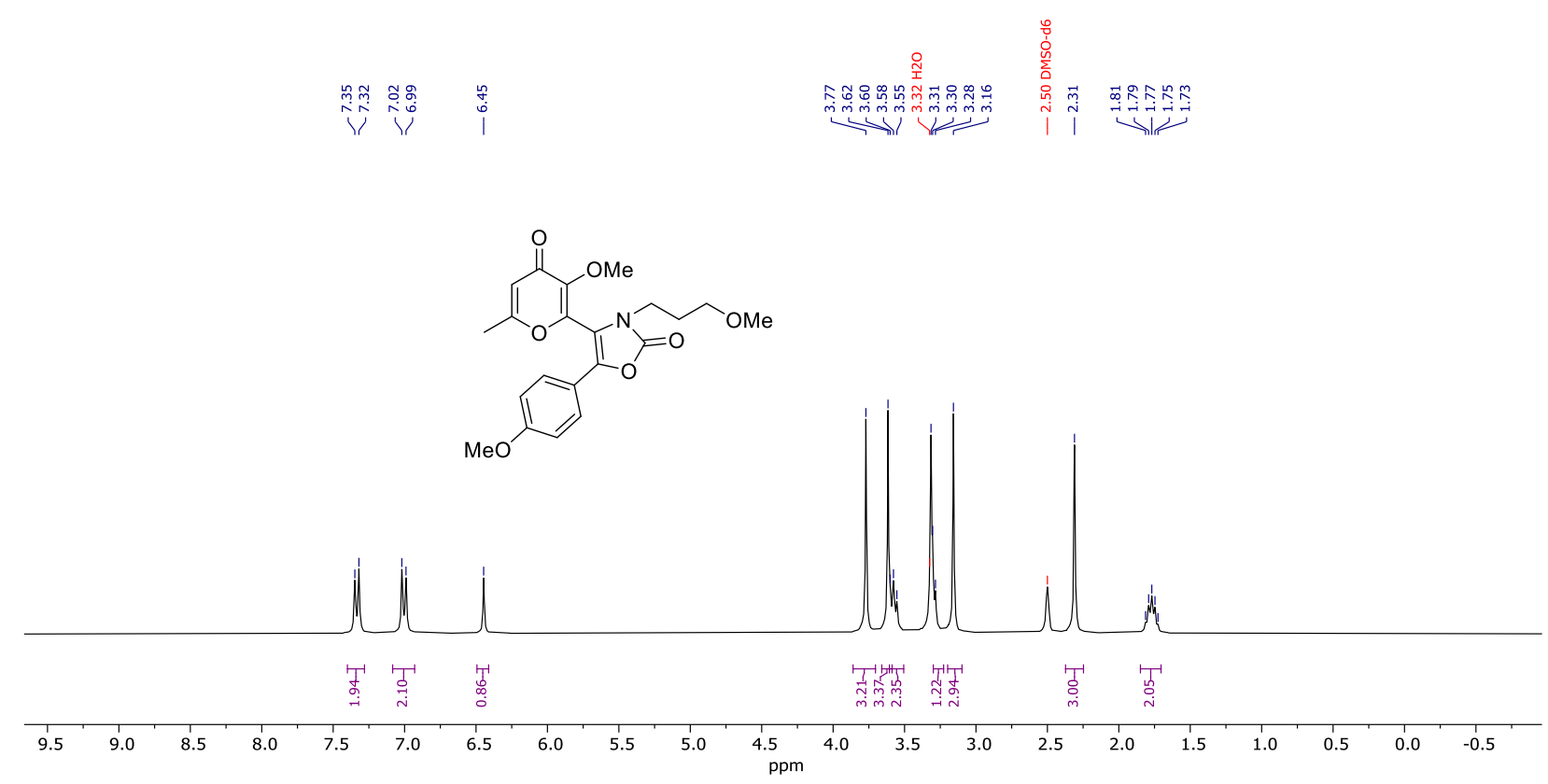

${ }^{13} \mathrm{C}\left\{{ }^{1} \mathrm{H}\right\}$ NMR spectrum (75 MHz) of $\mathbf{1 4 f}$ in DMSO- $d_{6}$
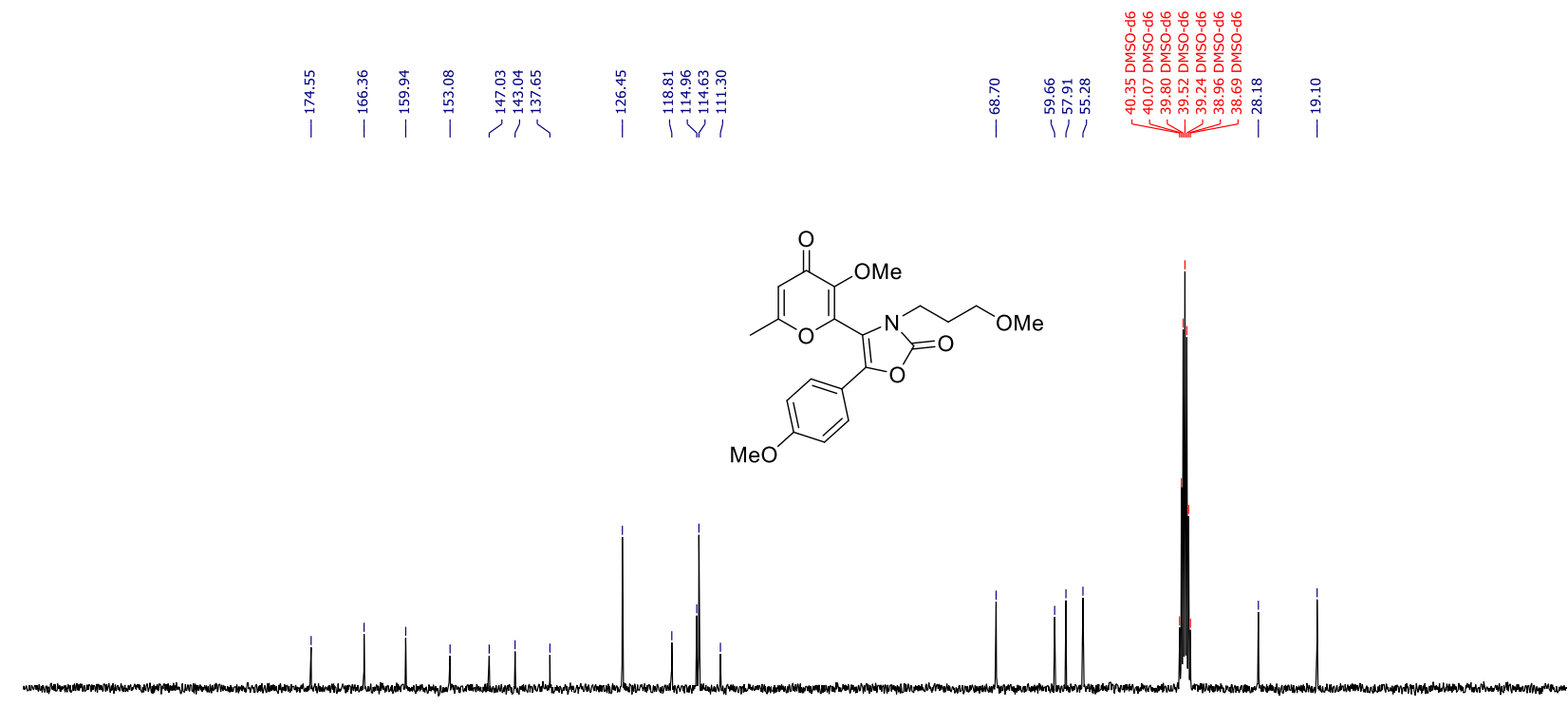

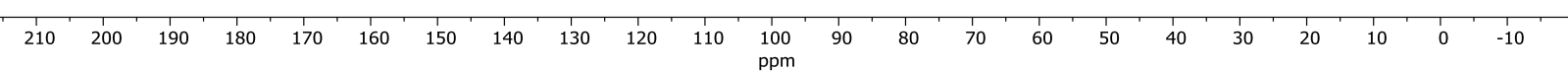


HRMS for compound $\mathbf{1 4 f}$

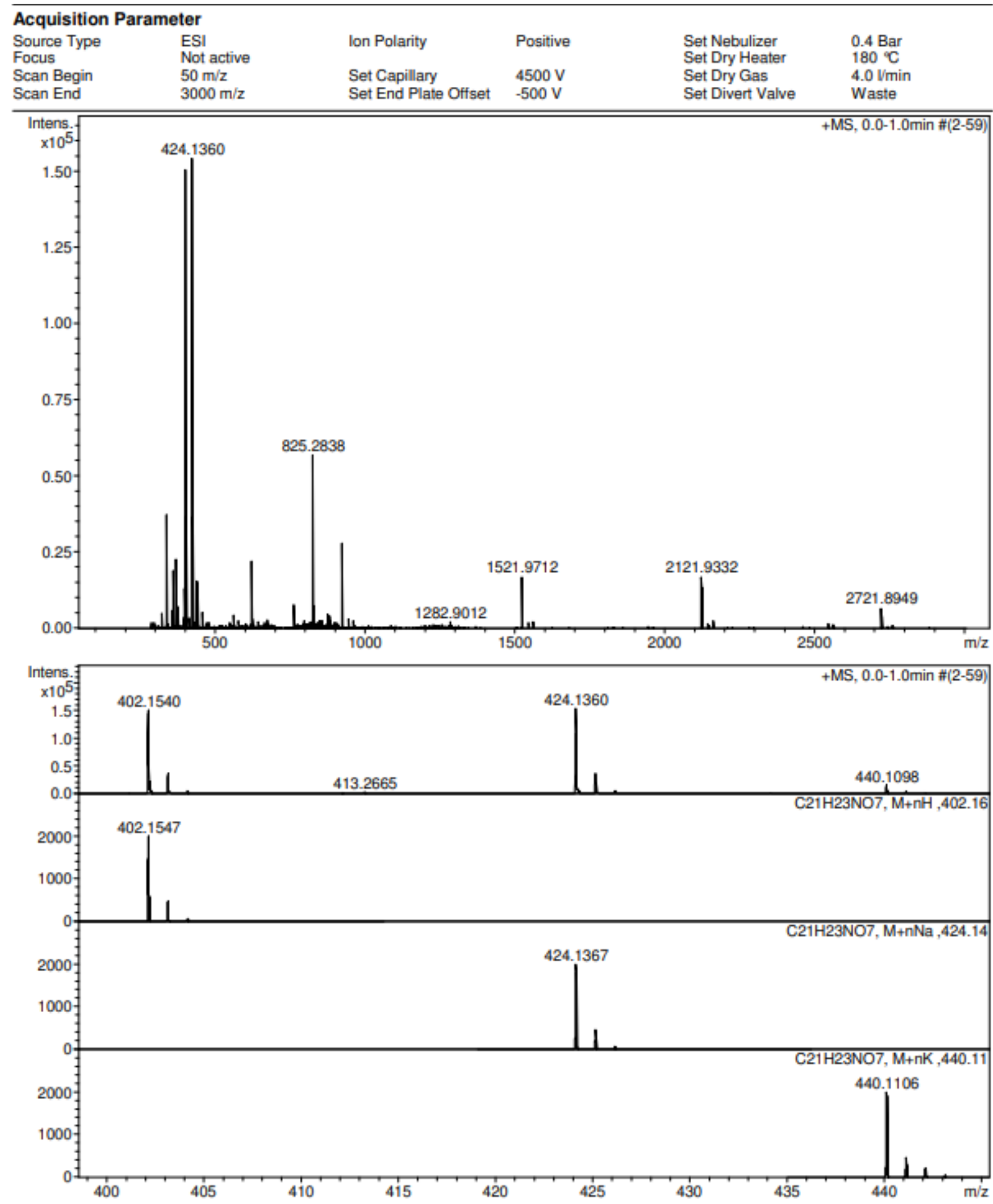


${ }^{1} \mathrm{H}$ NMR spectrum $\left(300 \mathrm{MHz}\right.$ ) of $14 \mathrm{~g}$ in DMSO- $d_{6}$

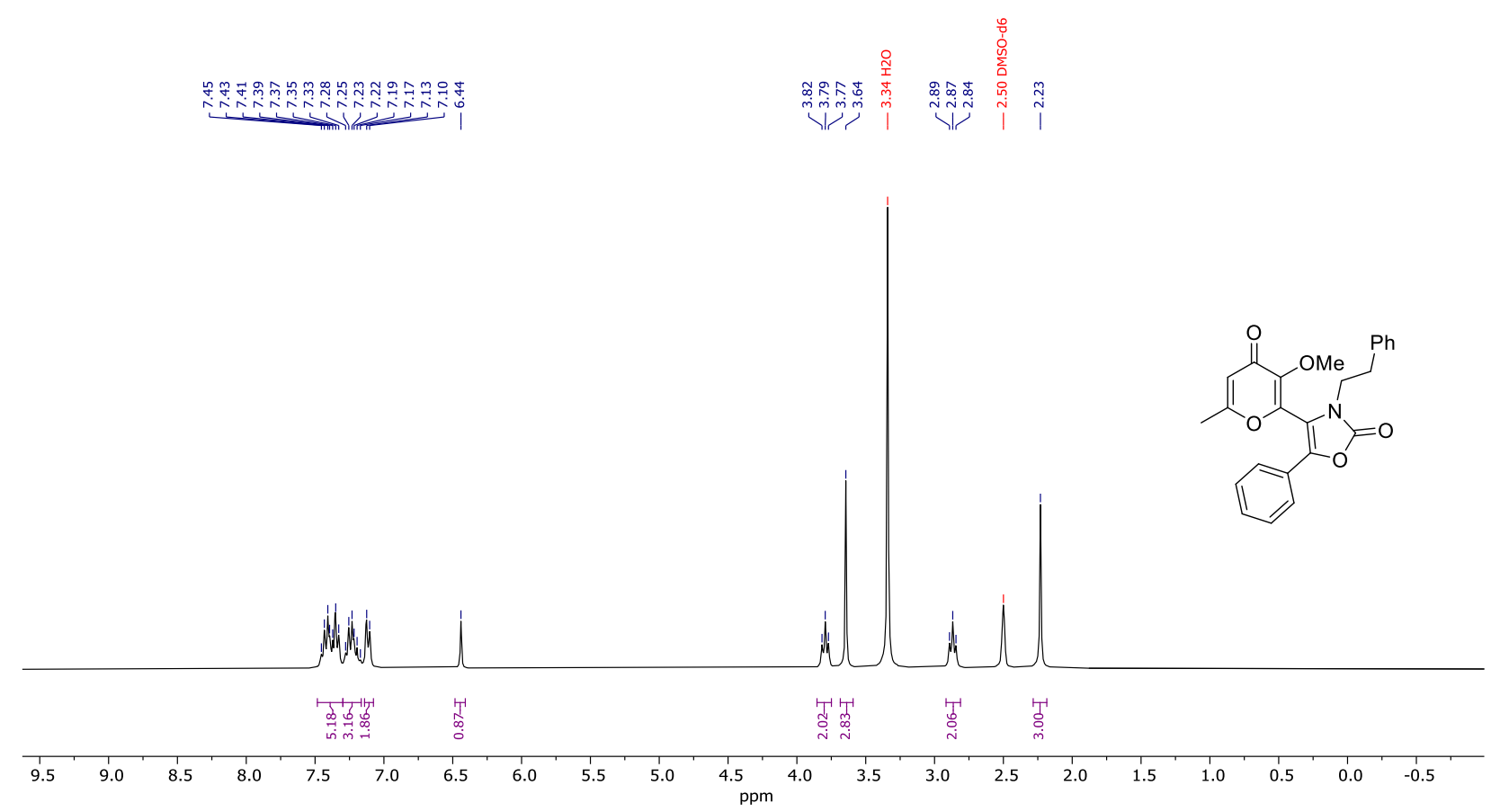

${ }^{13} \mathrm{C}\left\{{ }^{1} \mathrm{H}\right\}$ NMR spectrum (126 MHz) of $14 \mathrm{~g}$ in DMSO- $d_{6}$

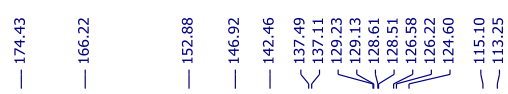
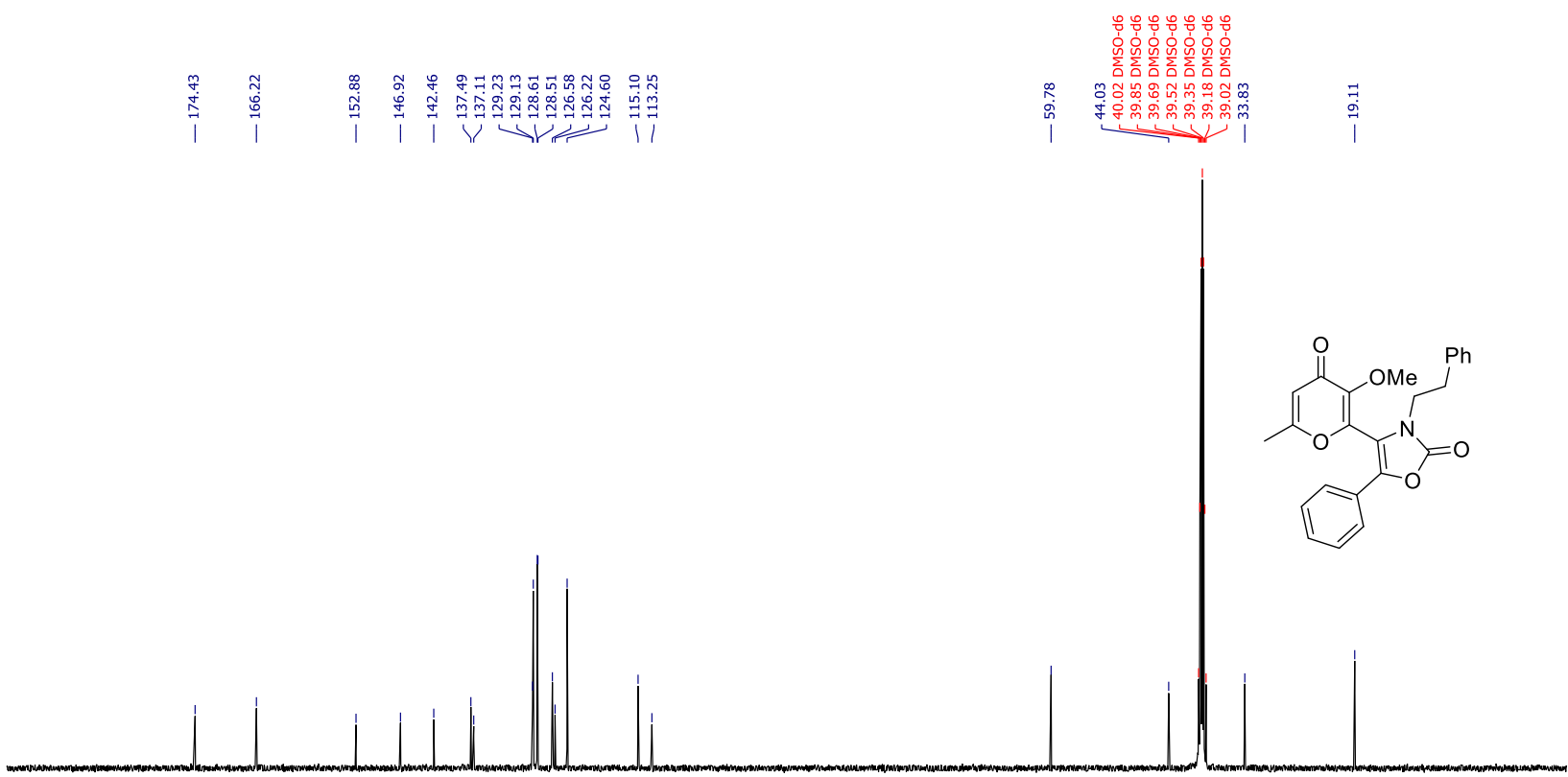

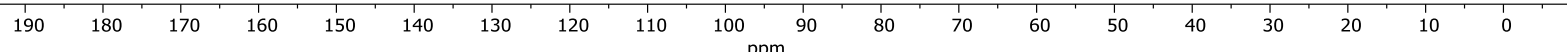


HRMS for compound $14 \mathrm{~g}$

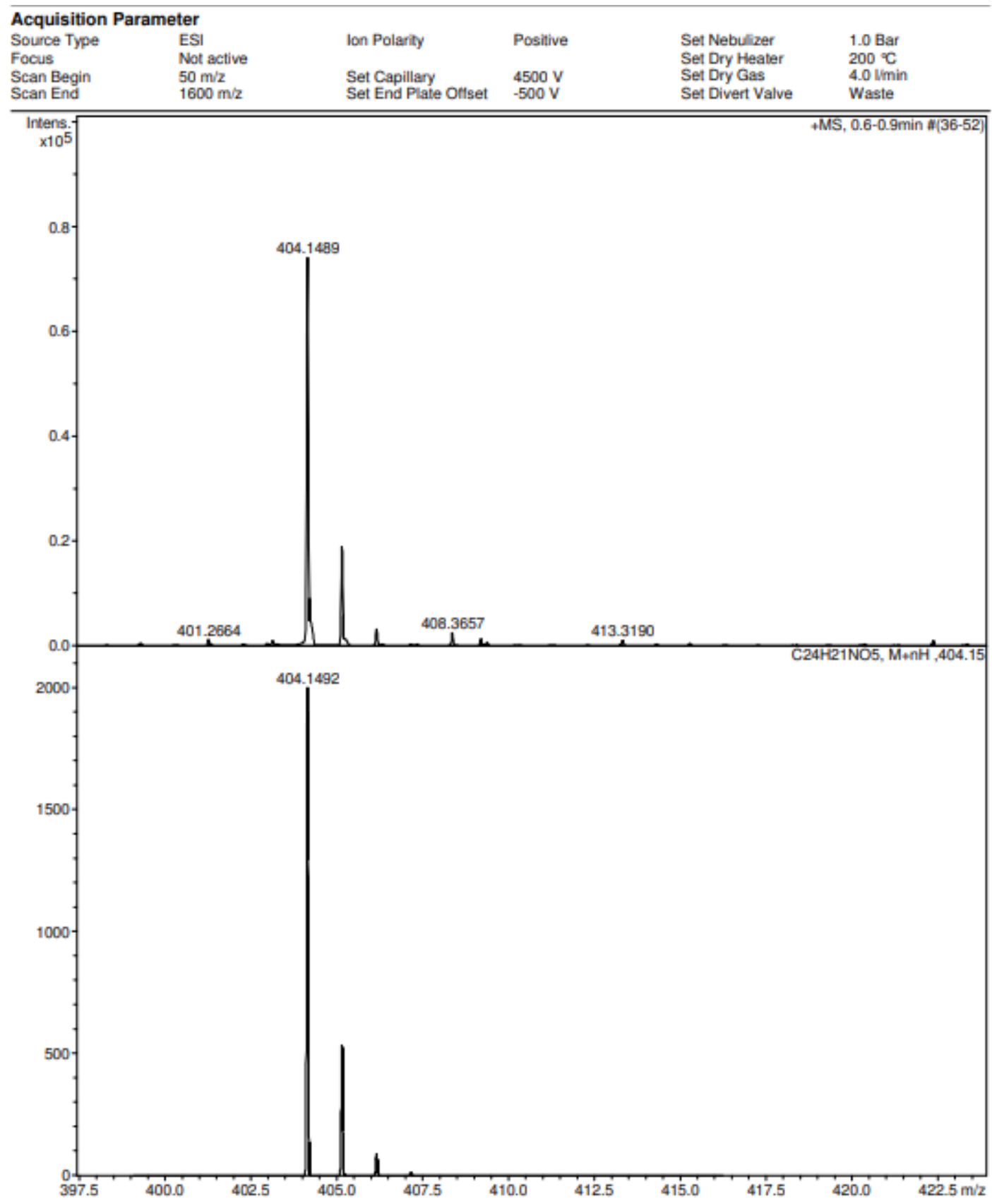


${ }^{1} \mathrm{H}$ NMR spectrum $\left(300 \mathrm{MHz}\right.$ ) of $14 \mathrm{~h}$ in DMSO- $d_{6}$

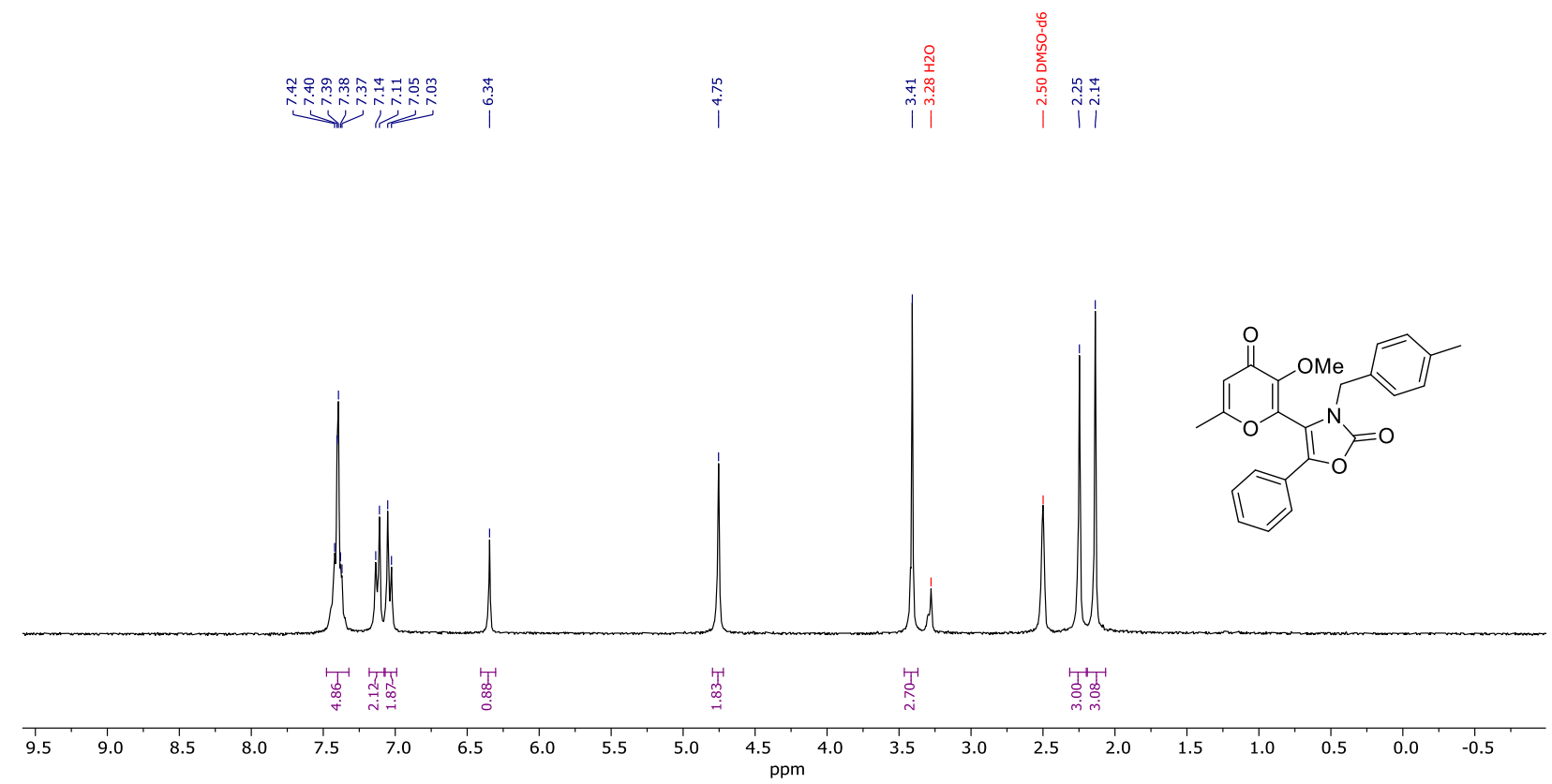

${ }^{13} \mathrm{C}\left\{{ }^{1} \mathrm{H}\right\}$ NMR spectrum $(75 \mathrm{MHz})$ of $\mathbf{1 4 h}$ in DMSO- $d_{6}$

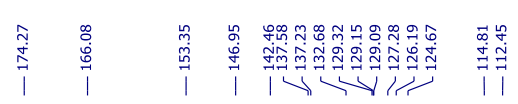
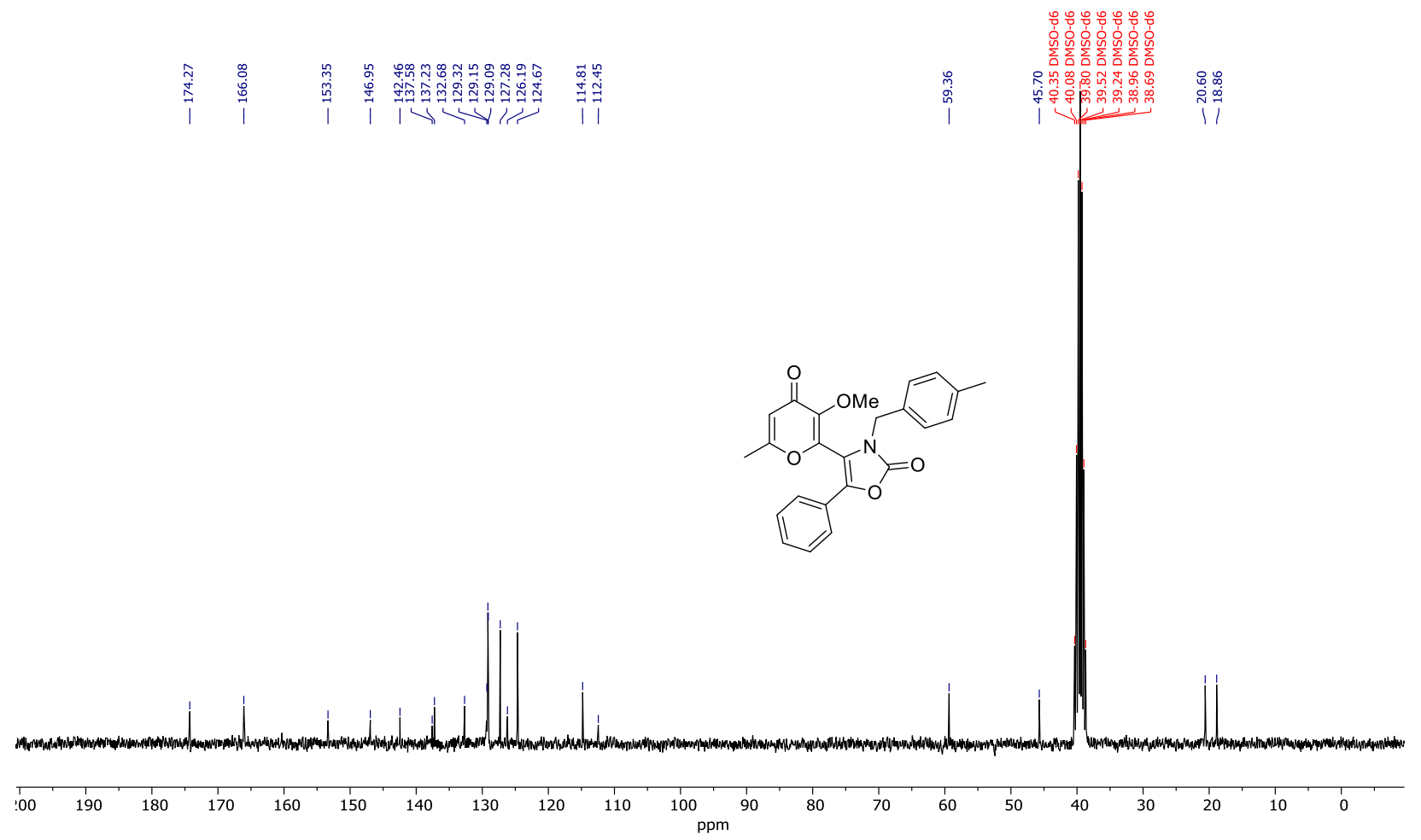
HRMS for compound $\mathbf{1 4 h}$

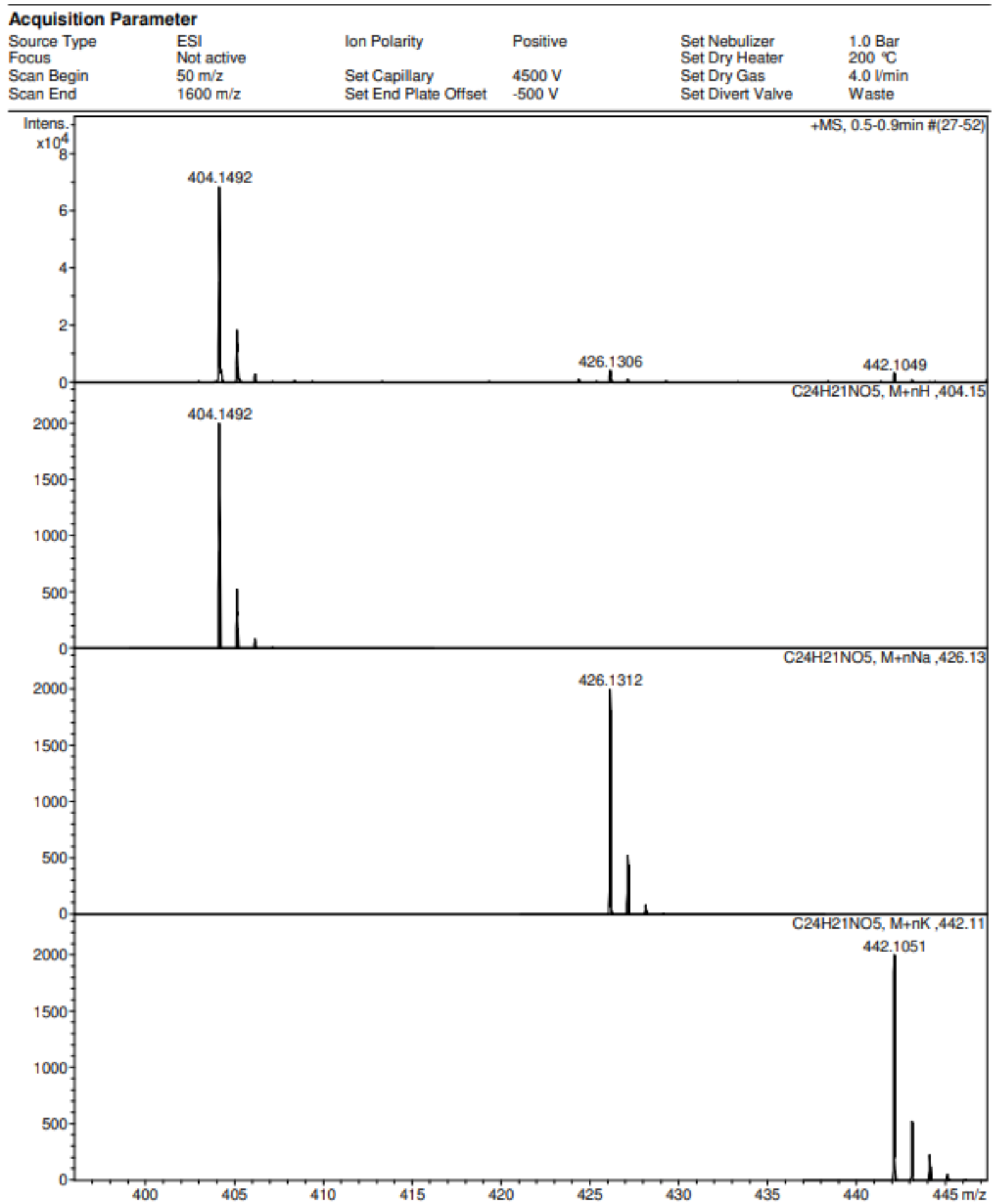


${ }^{1} \mathrm{H}$ NMR spectrum (300 MHz) of $14 \mathbf{i}$ in DMSO- $d_{6}$

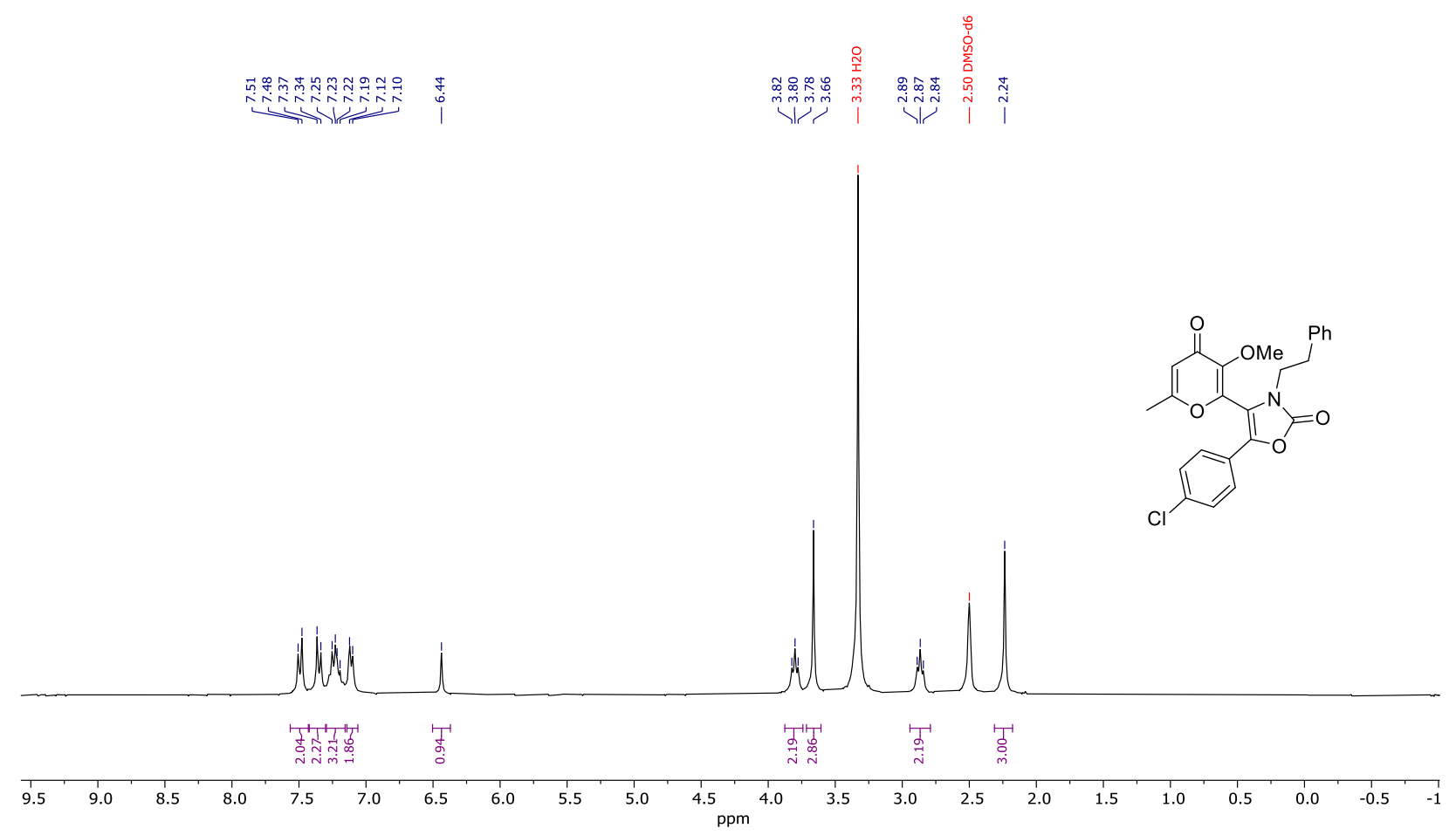

${ }^{13} \mathrm{C}\left\{{ }^{1} \mathrm{H}\right\}$ NMR spectrum (75 MHz) of $14 \mathbf{i}$ in DMSO- $d_{6}$

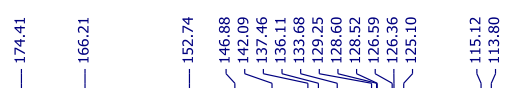
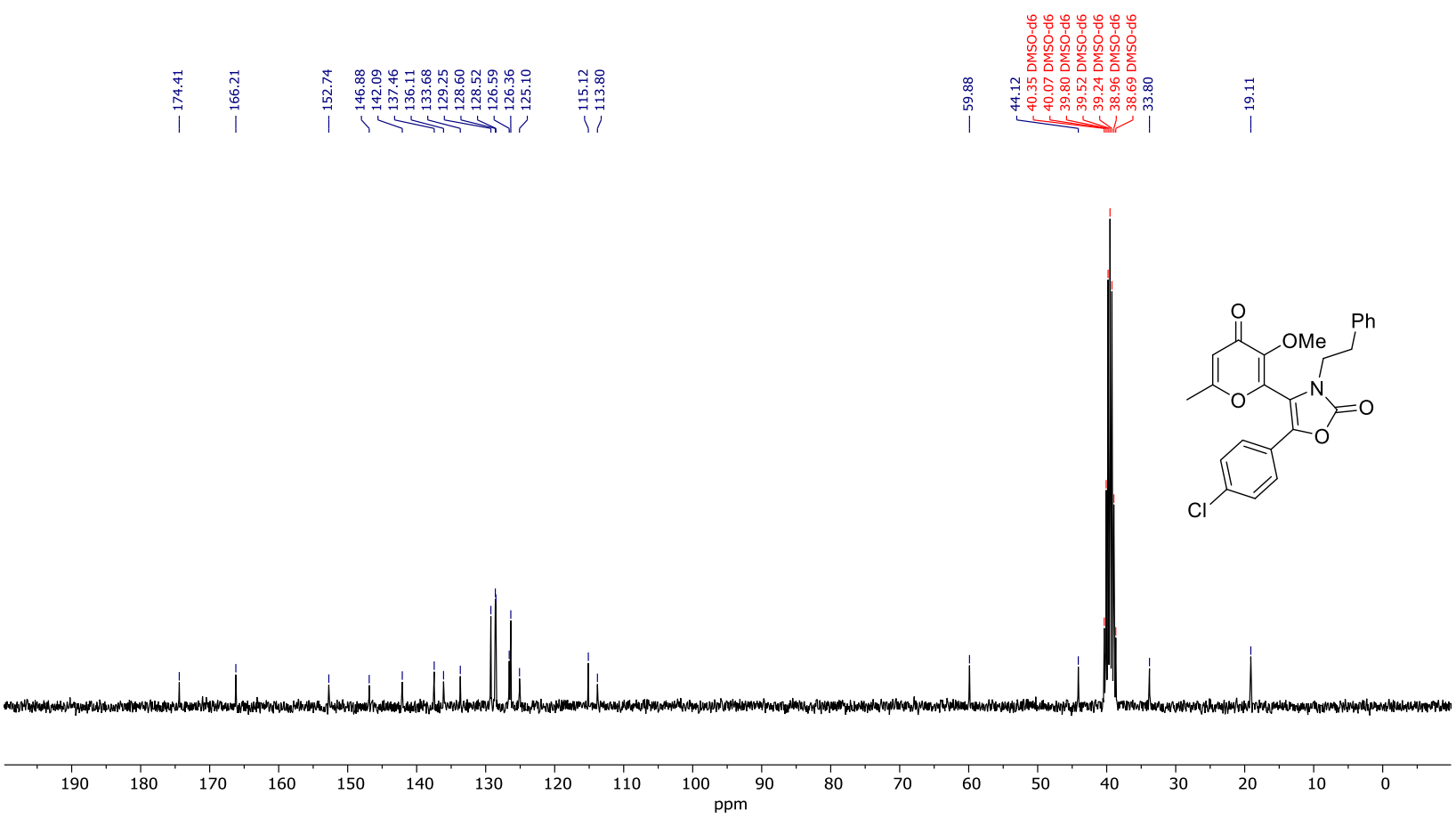
HRMS for compound $\mathbf{1 4} \mathbf{i}$

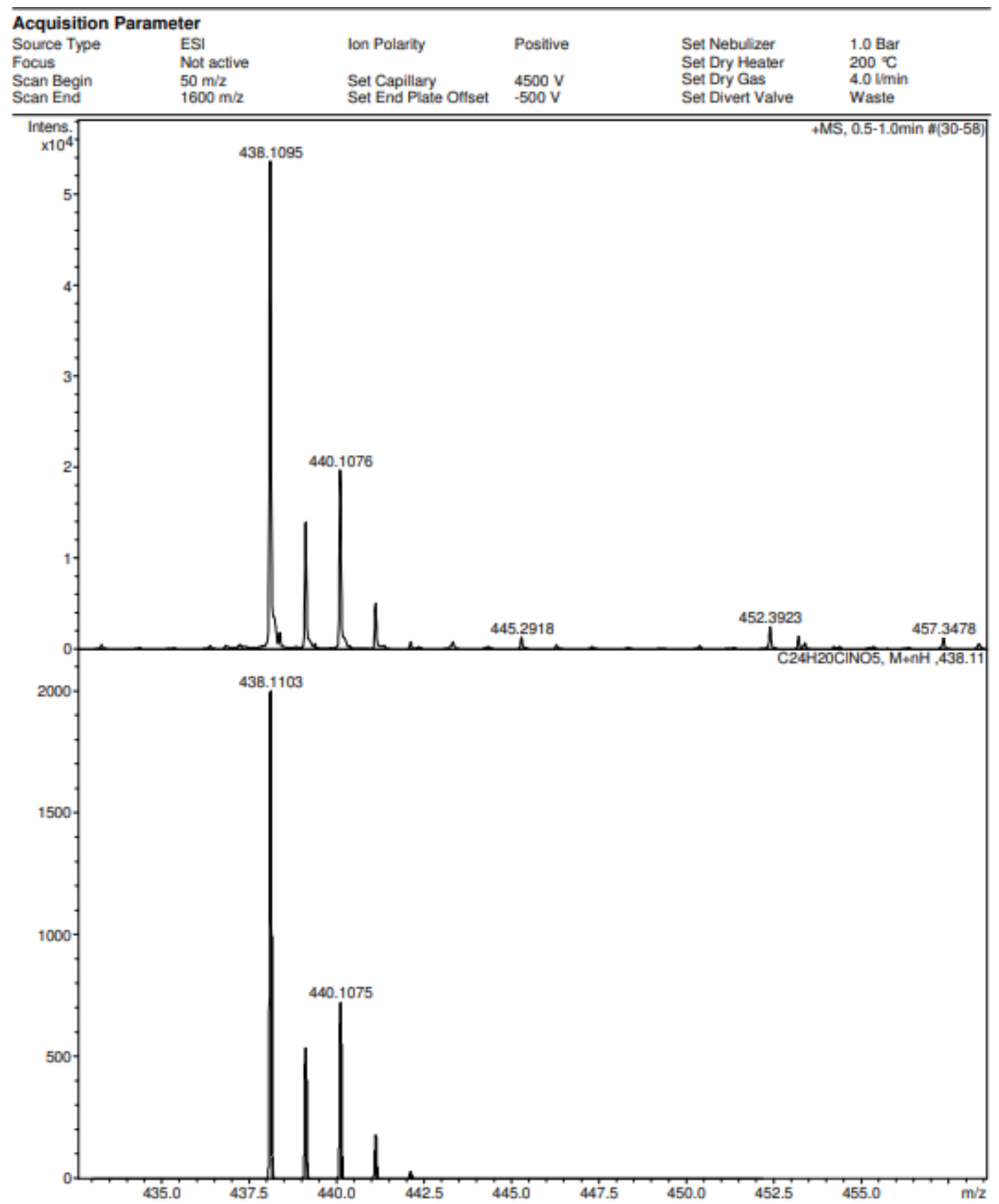


${ }^{1} \mathrm{H}$ NMR spectrum (300 MHz) of $14 \mathbf{j}$ in DMSO- $d_{6}$

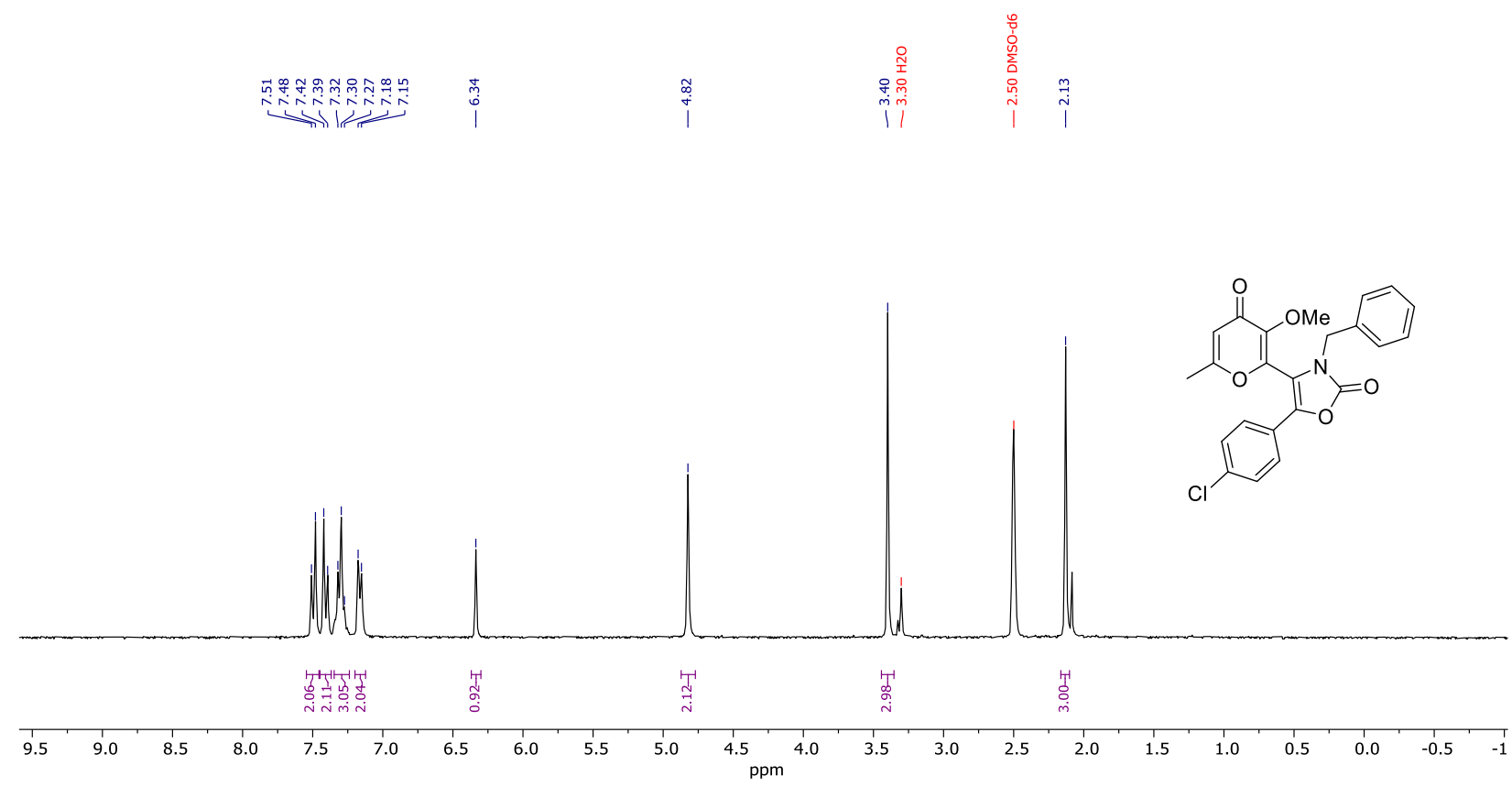

${ }^{13} \mathrm{C}\left\{{ }^{1} \mathrm{H}\right\}$ NMR spectrum (126 MHz) of $14 \mathrm{j}$ in DMSO- $d_{6}$

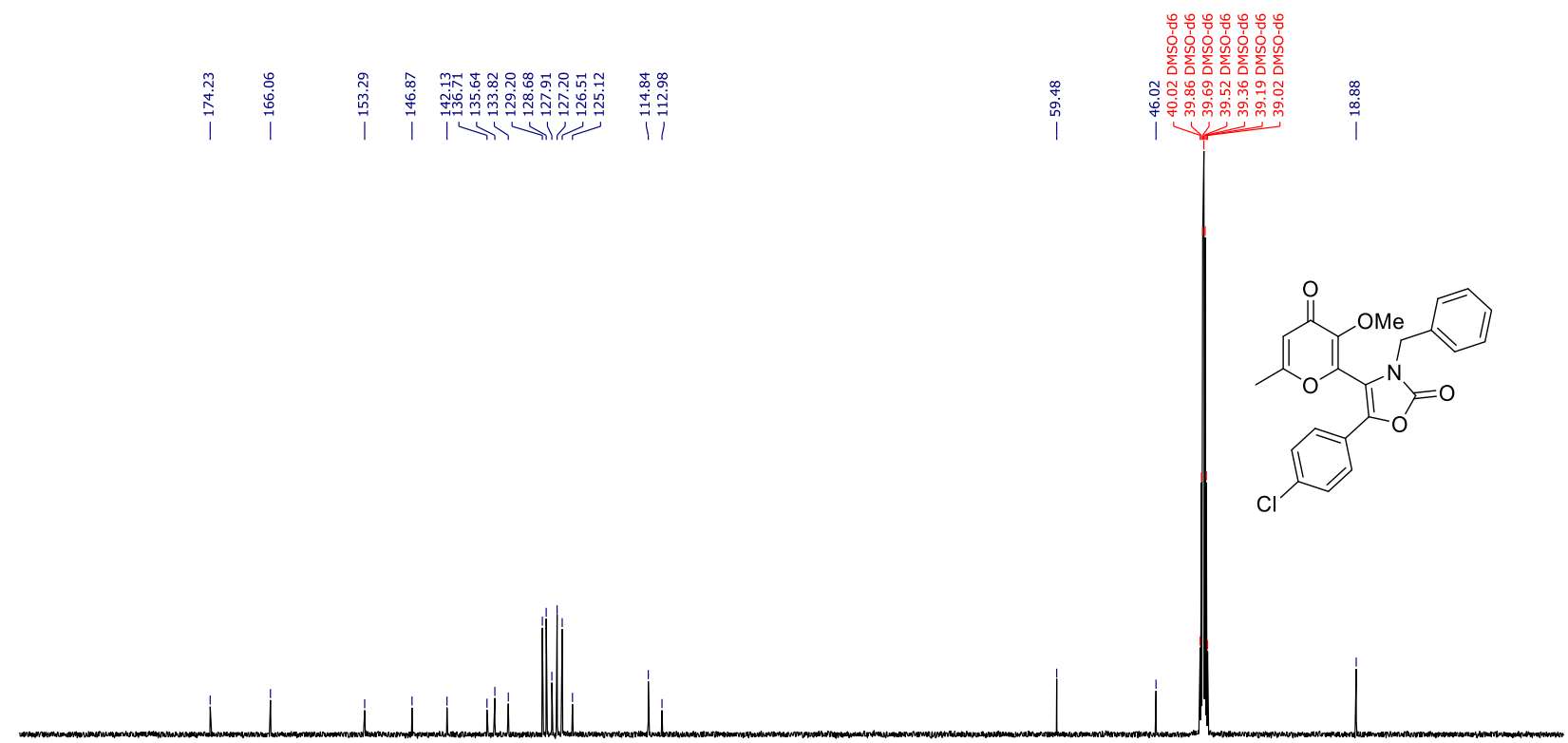

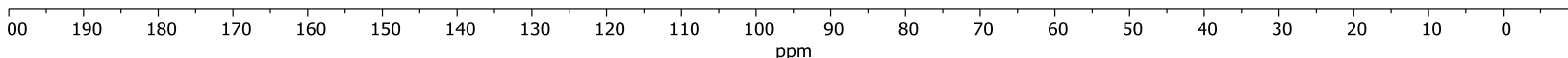


HRMS for compound $\mathbf{1 4 j}$

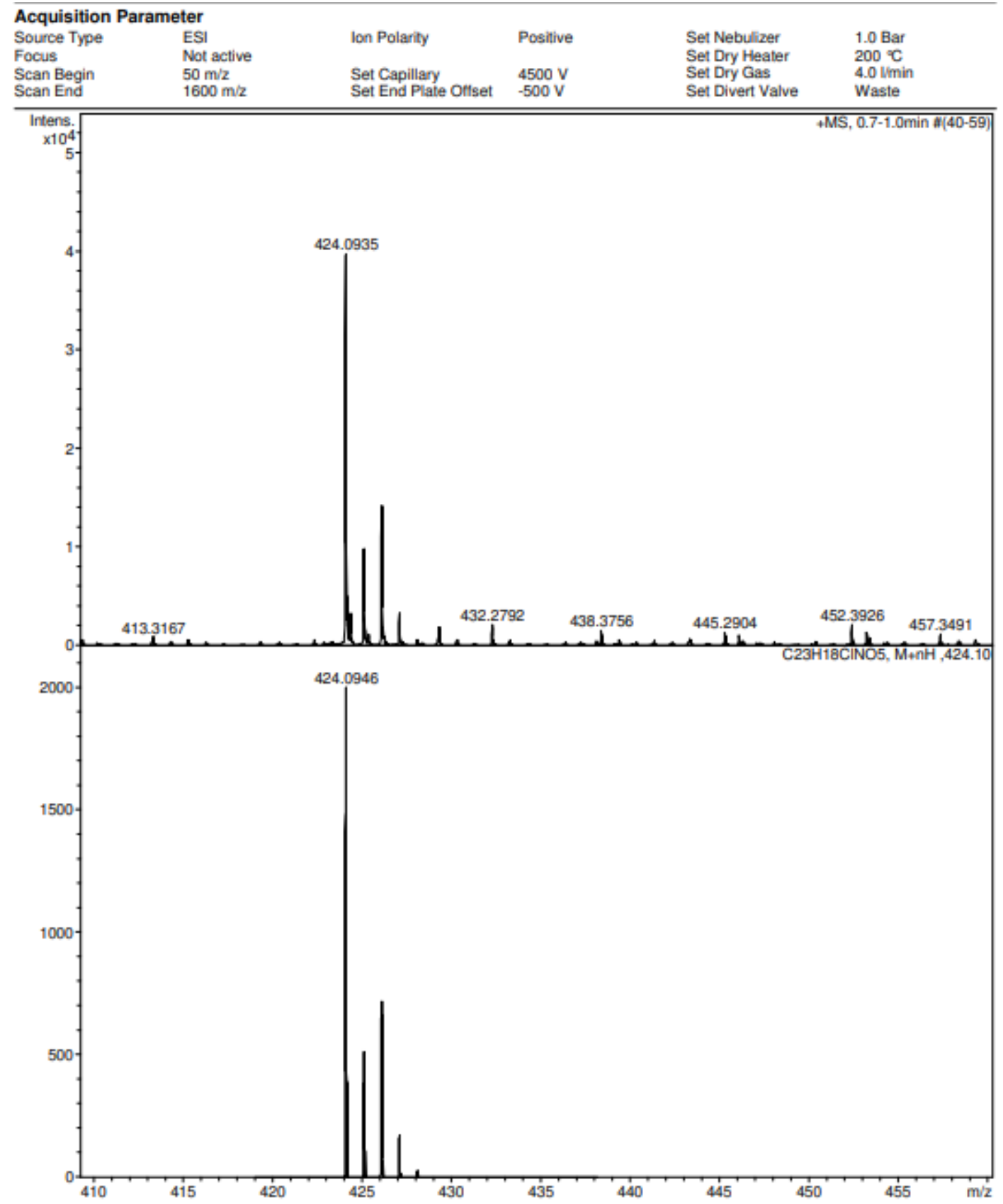


${ }^{1} \mathrm{H}$ NMR spectrum $(300 \mathrm{MHz})$ of $14 \mathbf{k}$ in DMSO- $d_{6}$

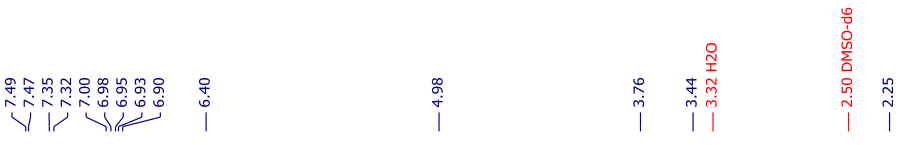<smiles>COc1ccc(-c2oc(=O)n(Cc3cccs3)c2-c2oc(C)cc(=O)c2OC)cc1</smiles>

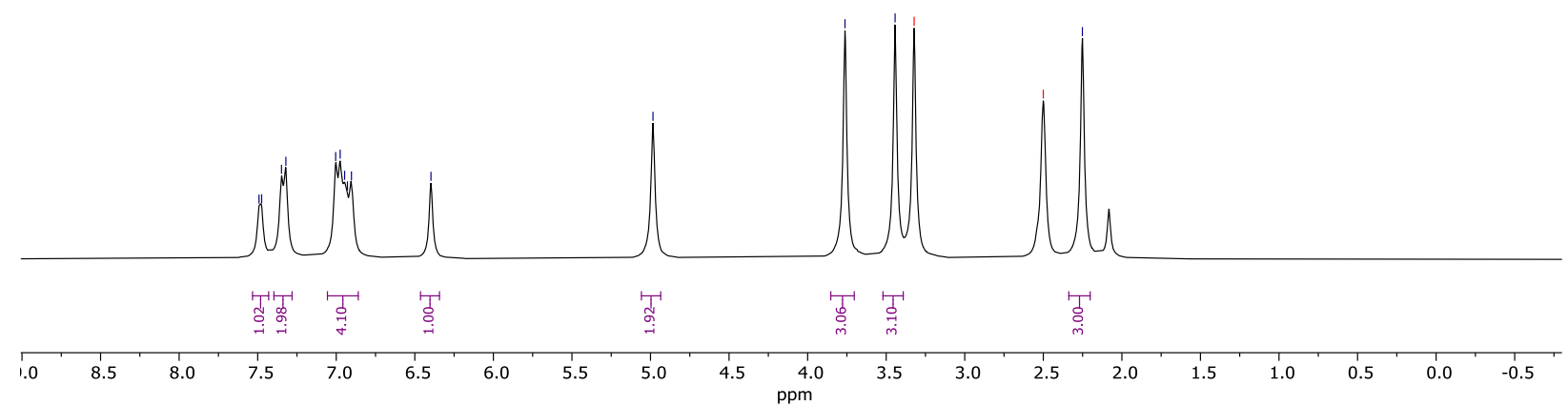

${ }^{13} \mathrm{C}\left\{{ }^{1} \mathrm{H}\right\}$ NMR spectrum $(75 \mathrm{MHz})$ of $\mathbf{1 4 k}$ in DMSO- $d_{6}$<smiles>COc1ccc(-c2oc(=O)n(Cc3cccs3)c2-c2oc(C)cc(=O)c2OC)cc1</smiles>

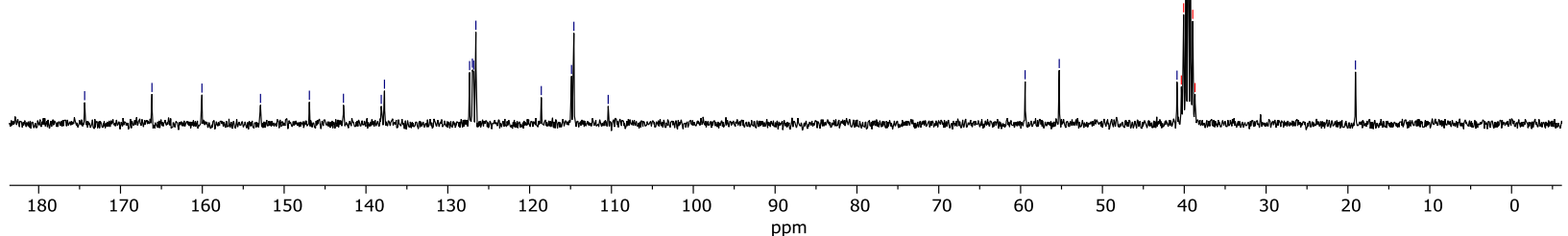


HRMS for compound $\mathbf{1 4 k}$

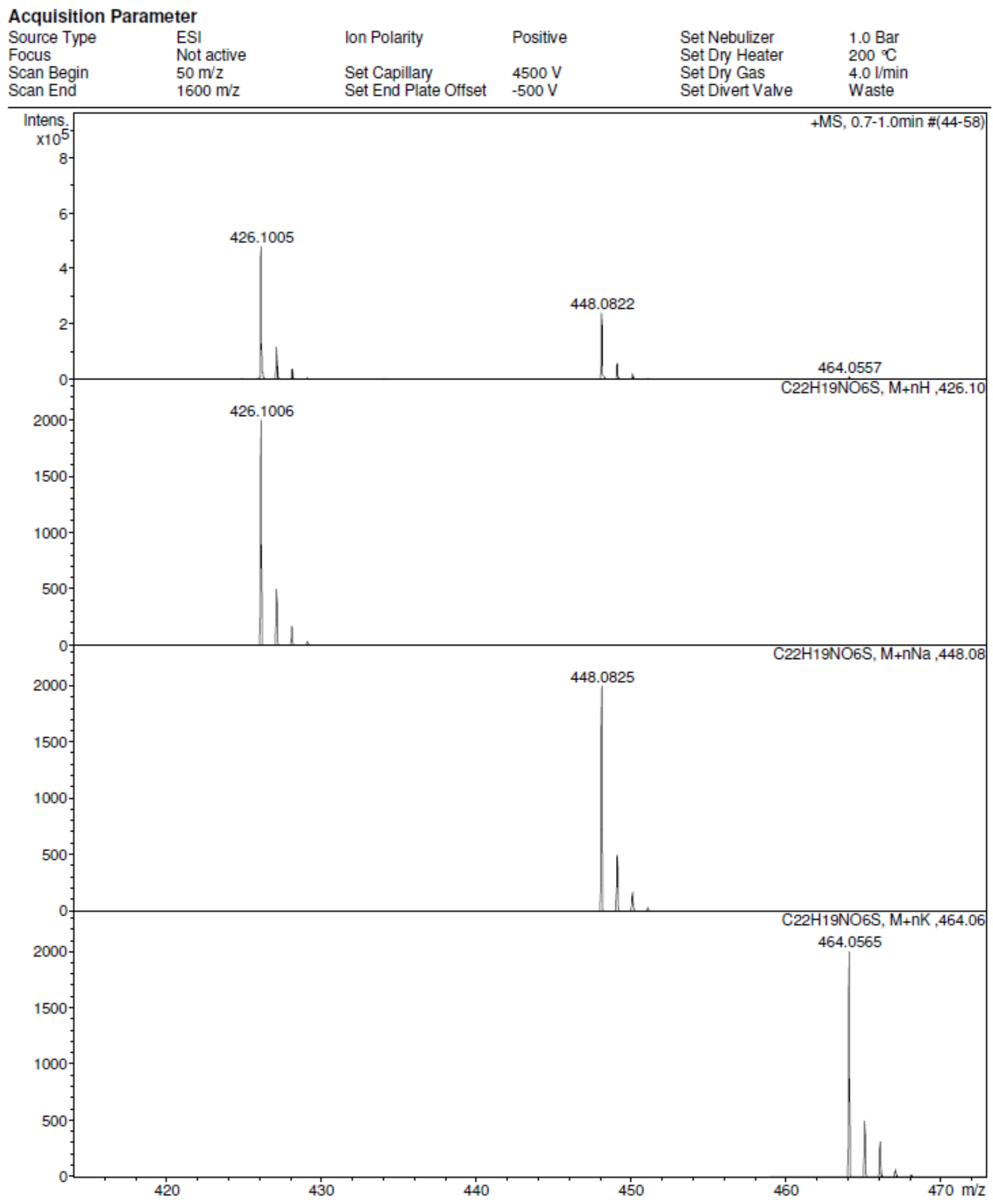


6. Copies of ${ }^{1} \mathrm{H},{ }^{13} \mathrm{C}$ NMR and HRMS for photoproducts $\mathbf{1 5 .}$

${ }^{1} \mathrm{H}$ NMR spectrum (300 MHz) of $15 \mathrm{a}$ in DMSO- $d_{6}$

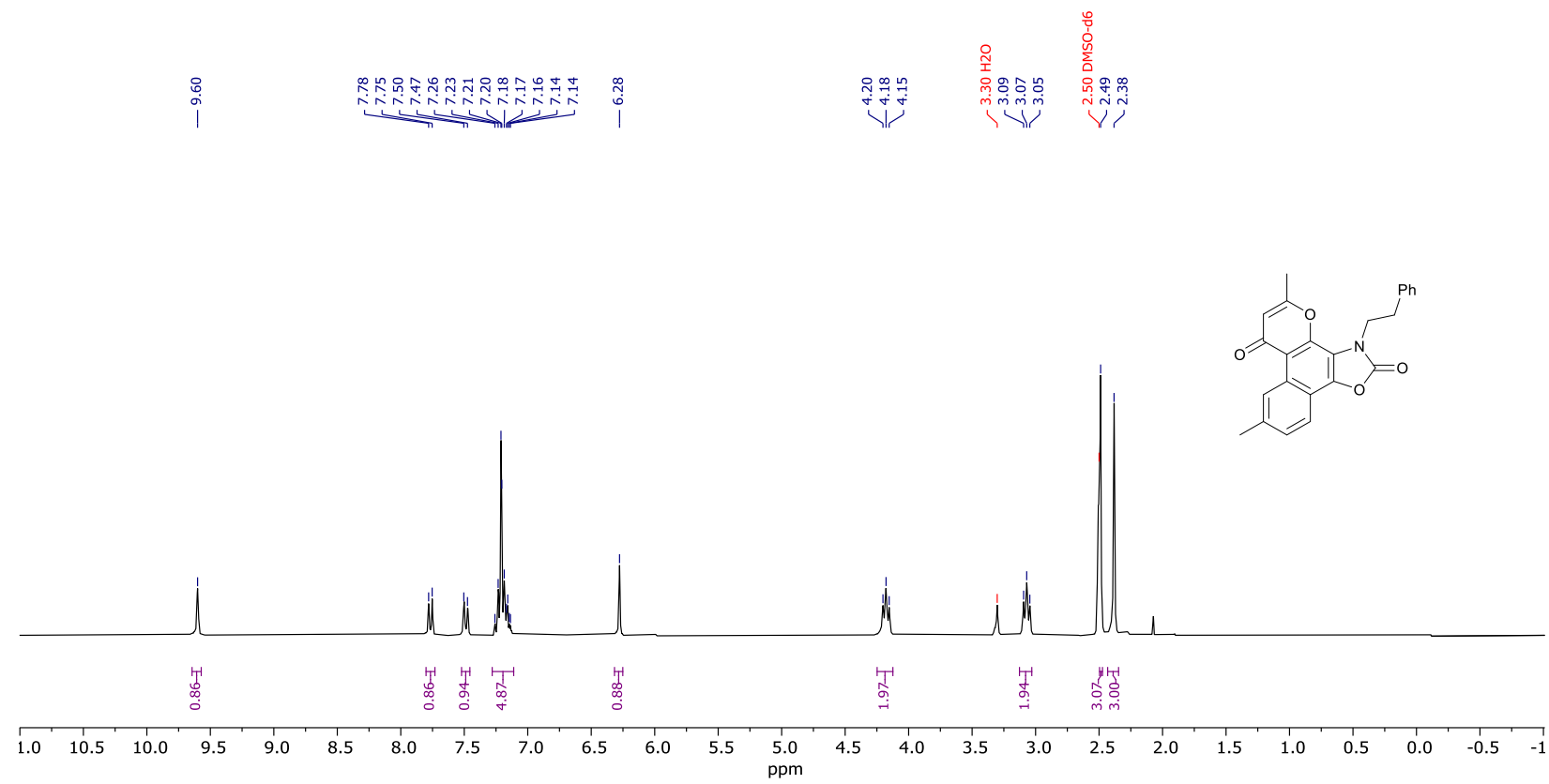

${ }^{13} \mathrm{C}\left\{{ }^{1} \mathrm{H}\right\}$ NMR spectrum (126 MHz) of 15a in DMSO- $d_{6}$

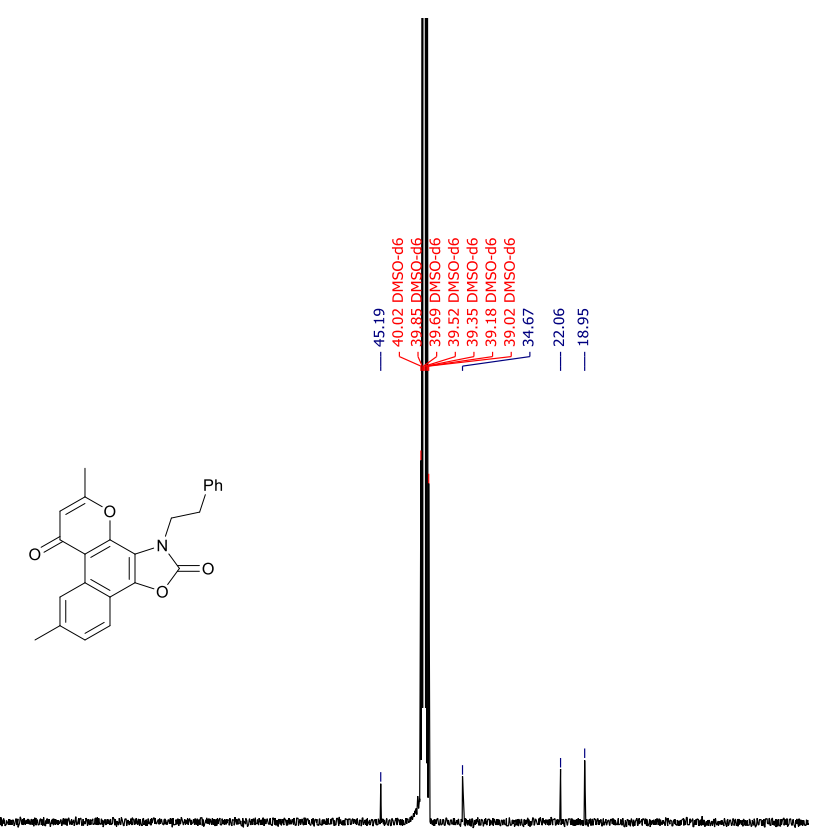

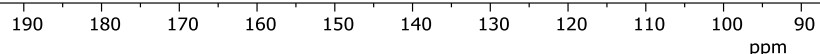


HRMS for compound 15a

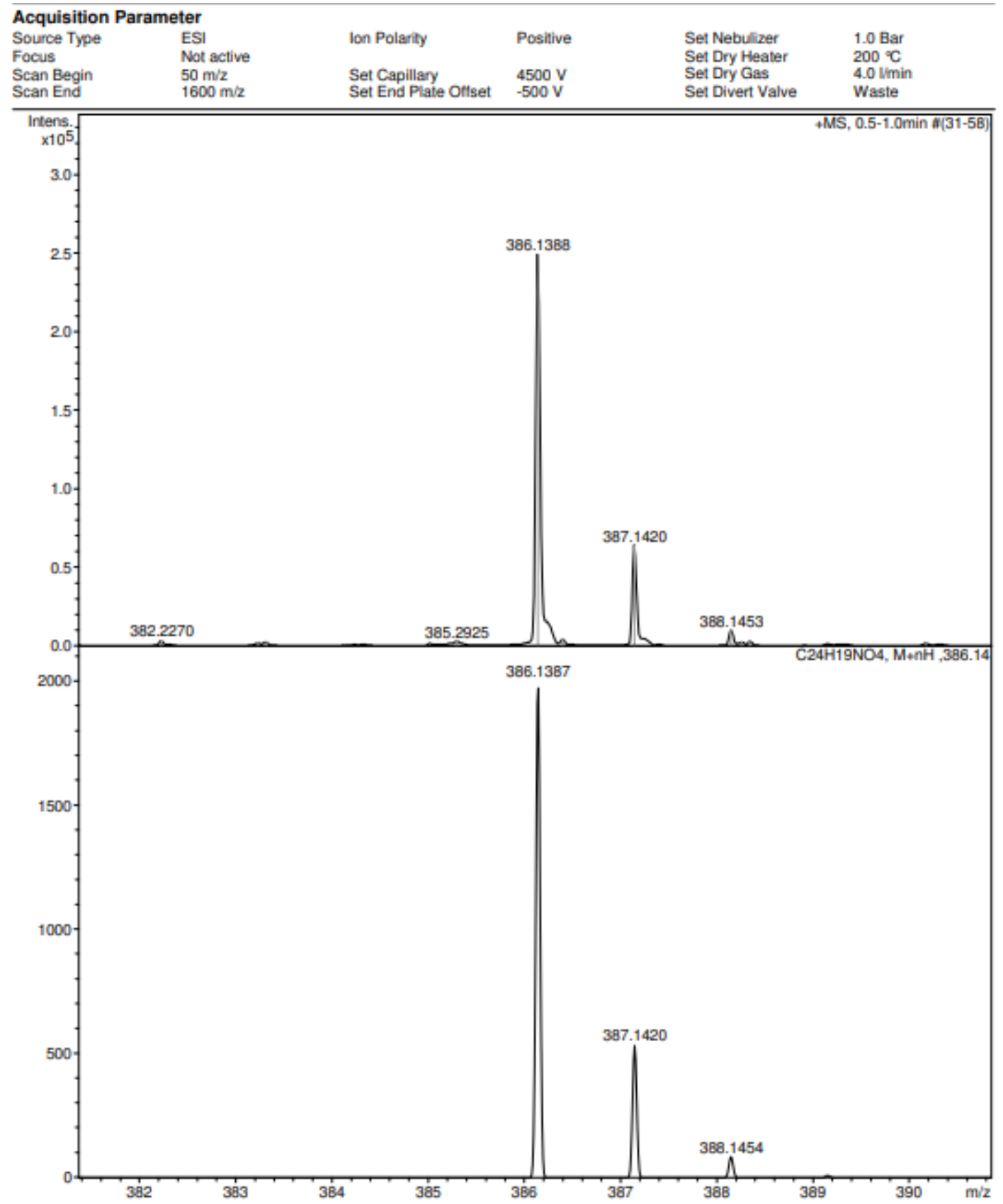


${ }^{1} \mathrm{H}$ NMR spectrum $(500 \mathrm{MHz})$ of $\mathbf{1 5} \mathbf{b}$ in DMSO- $d_{6}$

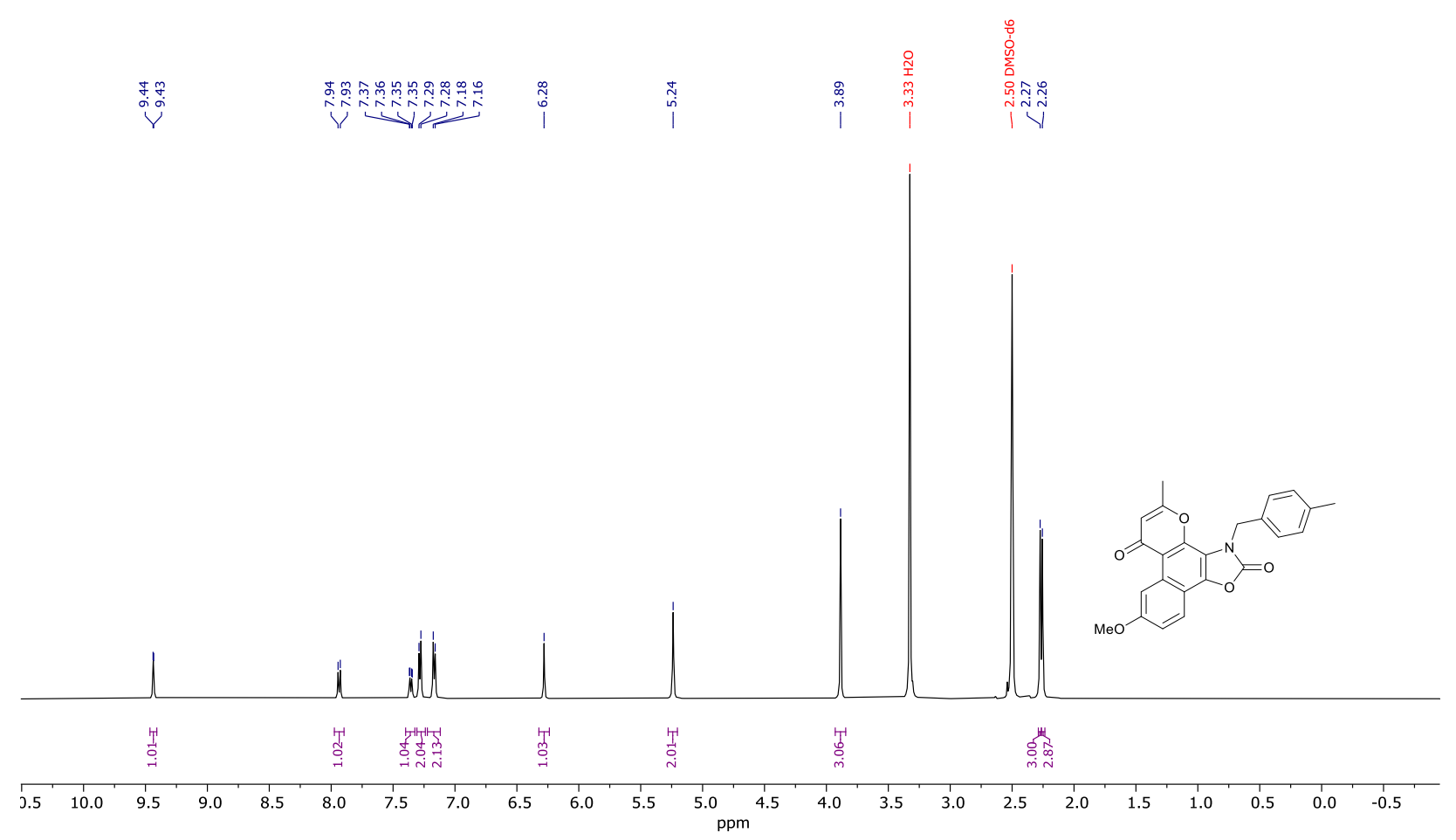

${ }^{13} \mathrm{C}\left\{{ }^{1} \mathrm{H}\right\}$ NMR spectrum $(126 \mathrm{MHz})$ of $\mathbf{1 5 b}$ in DMSO- $d_{6}$

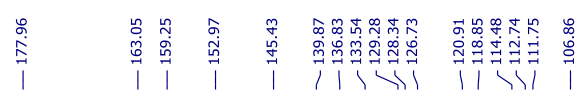
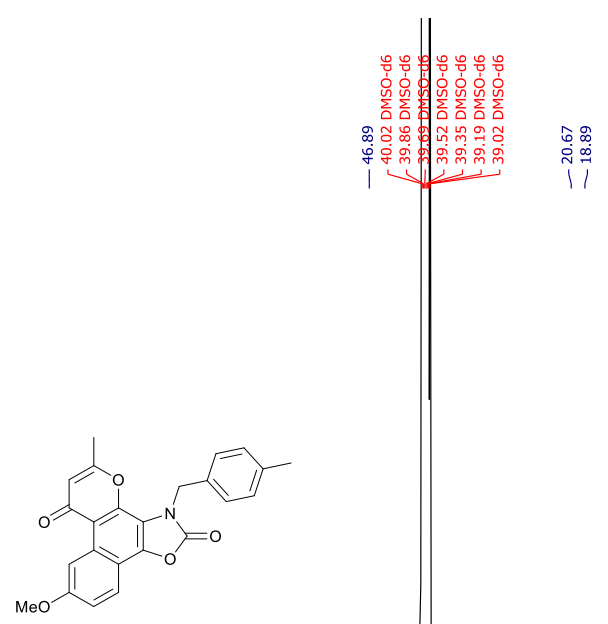

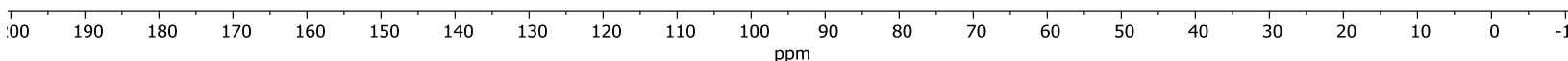


HRMS for compound $\mathbf{1 5 b}$

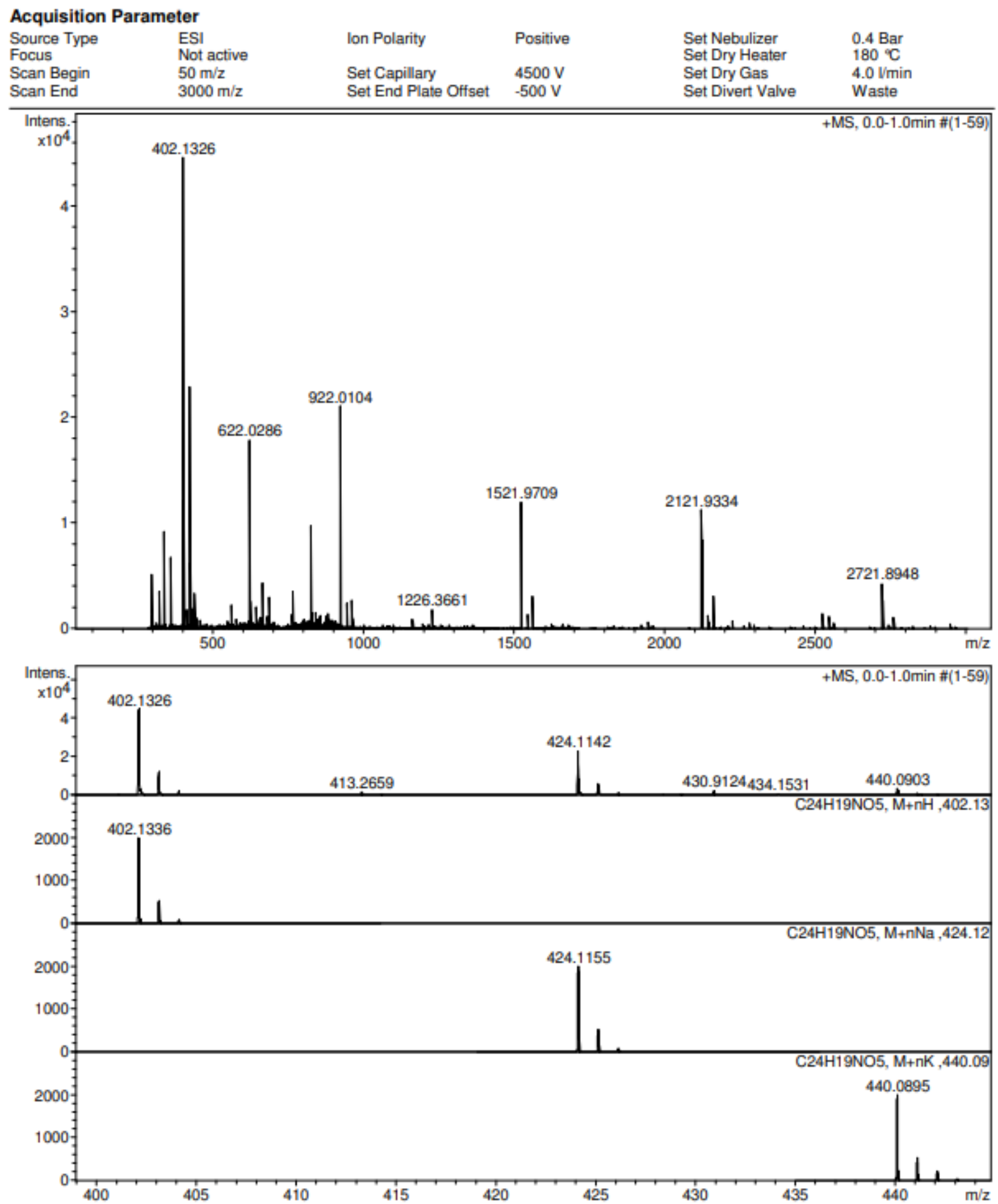


${ }^{1} \mathrm{H}$ NMR spectrum $(500 \mathrm{MHz})$ of $15 \mathrm{c}$ in DMSO- $d_{6}$

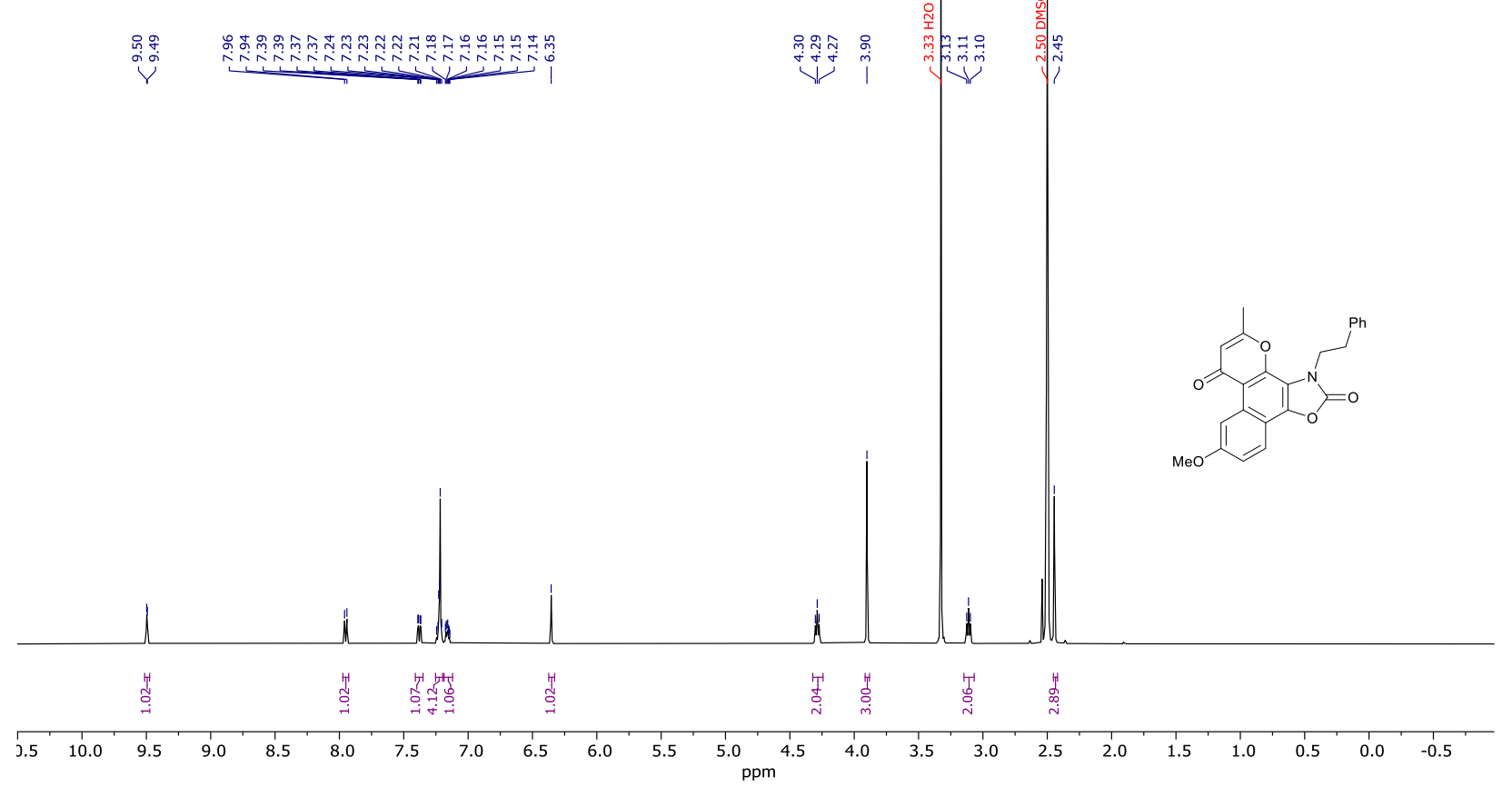

${ }^{13} \mathrm{C}\left\{{ }^{1} \mathrm{H}\right\}$ NMR spectrum (126 MHz) of $15 \mathrm{c}$ in DMSO- $d_{6}$
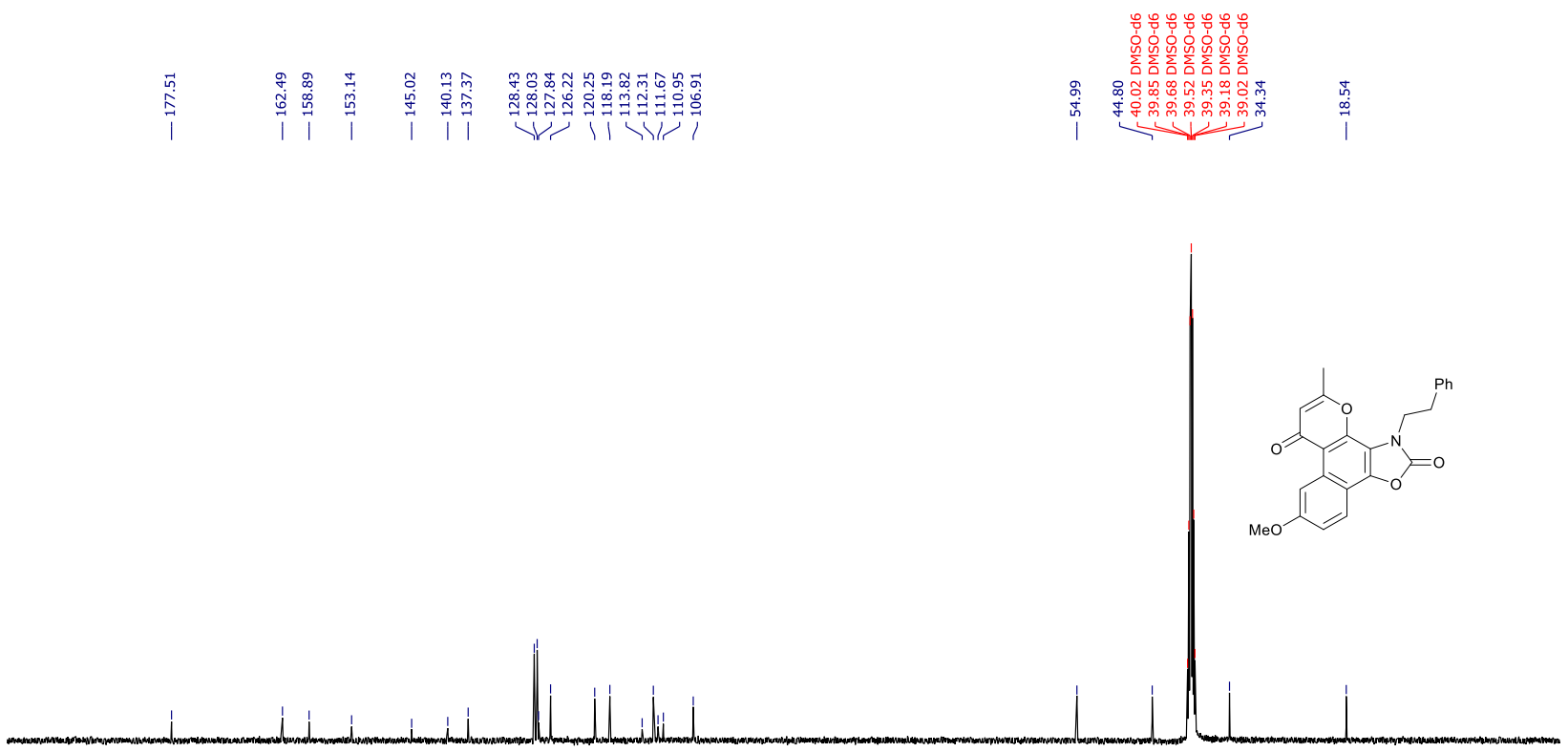

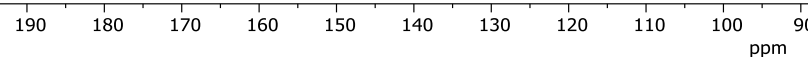


HRMS for compound 15c

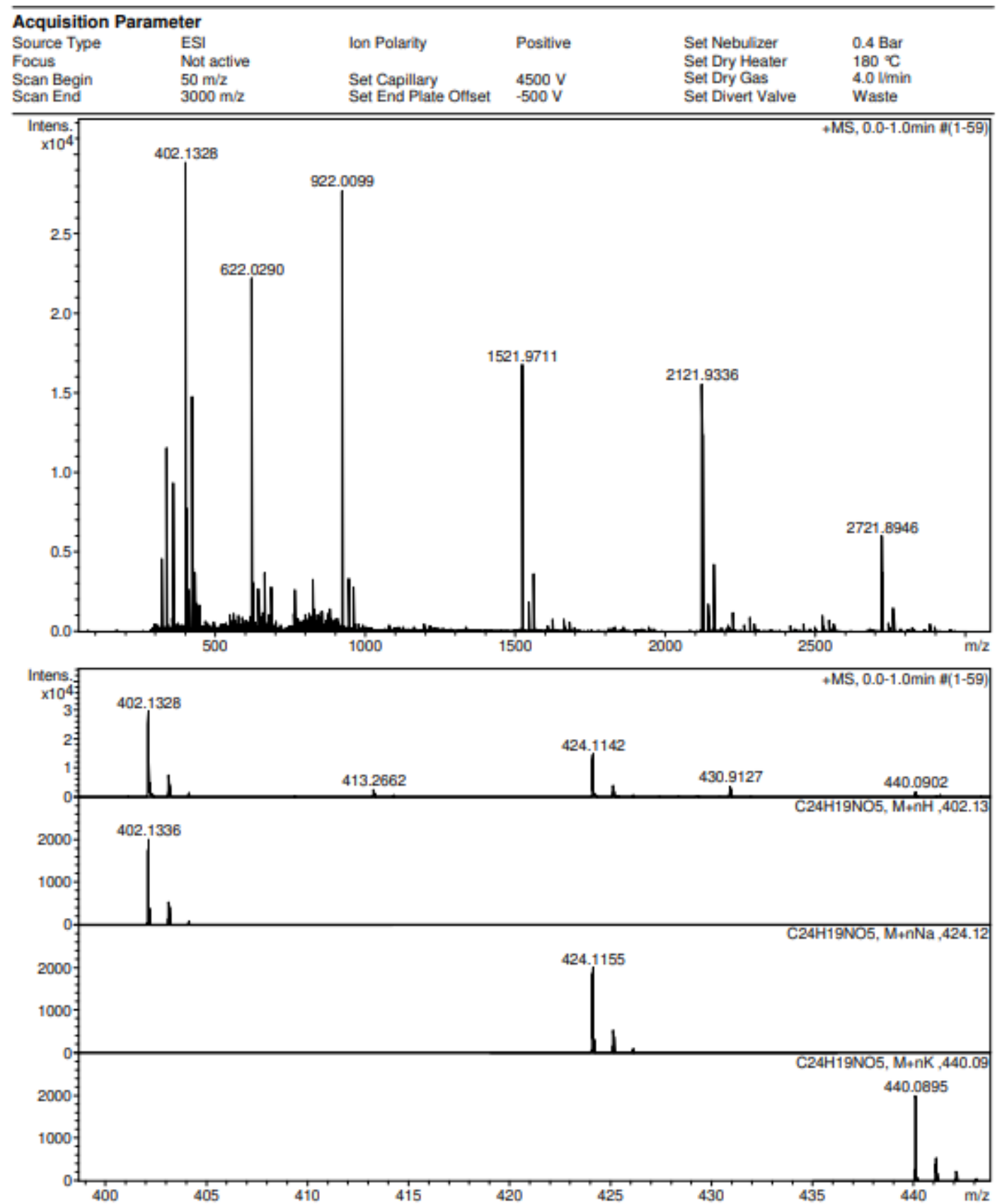


${ }^{1} \mathrm{H}$ NMR spectrum $\left(300 \mathrm{MHz}\right.$ ) of $15 \mathrm{~d}$ in DMSO- $d_{6}$

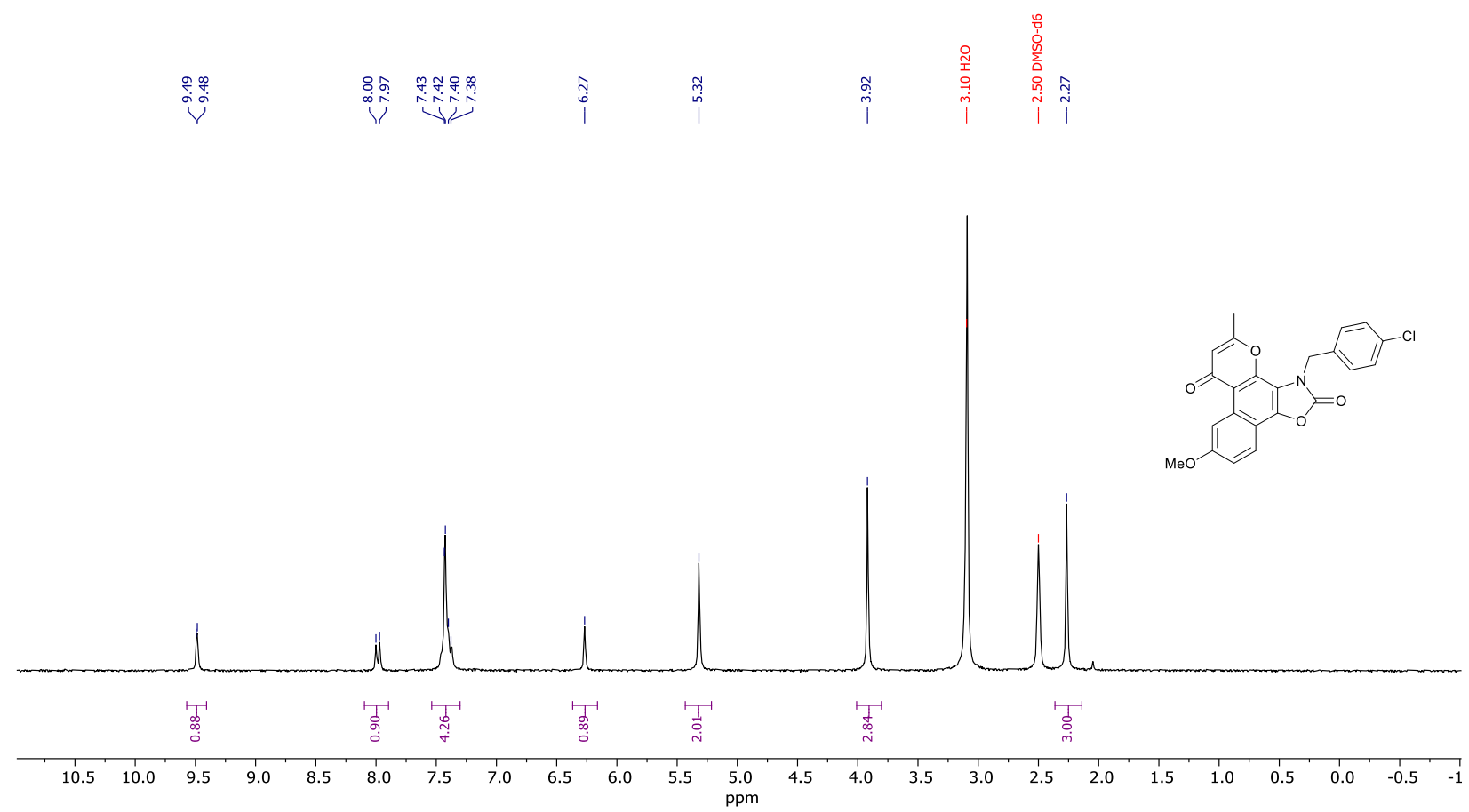

${ }^{13} \mathrm{C}\left\{{ }^{1} \mathrm{H}\right\}$ NMR spectrum $(126 \mathrm{MHz})$ of $15 \mathrm{~d}$ in DMSO- $d_{6}$

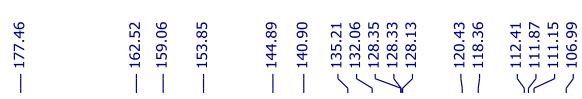

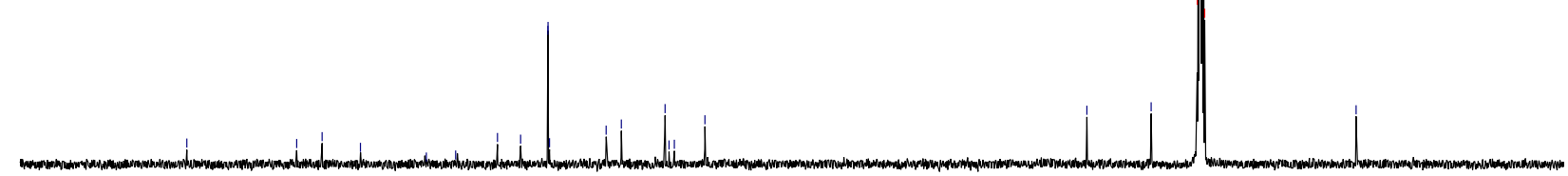

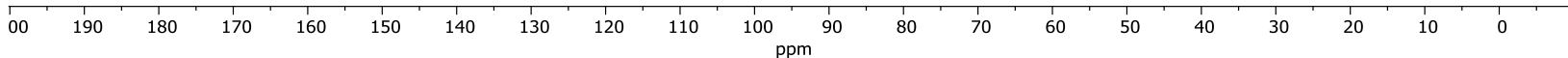


HRMS for compound $\mathbf{1 5 d}$

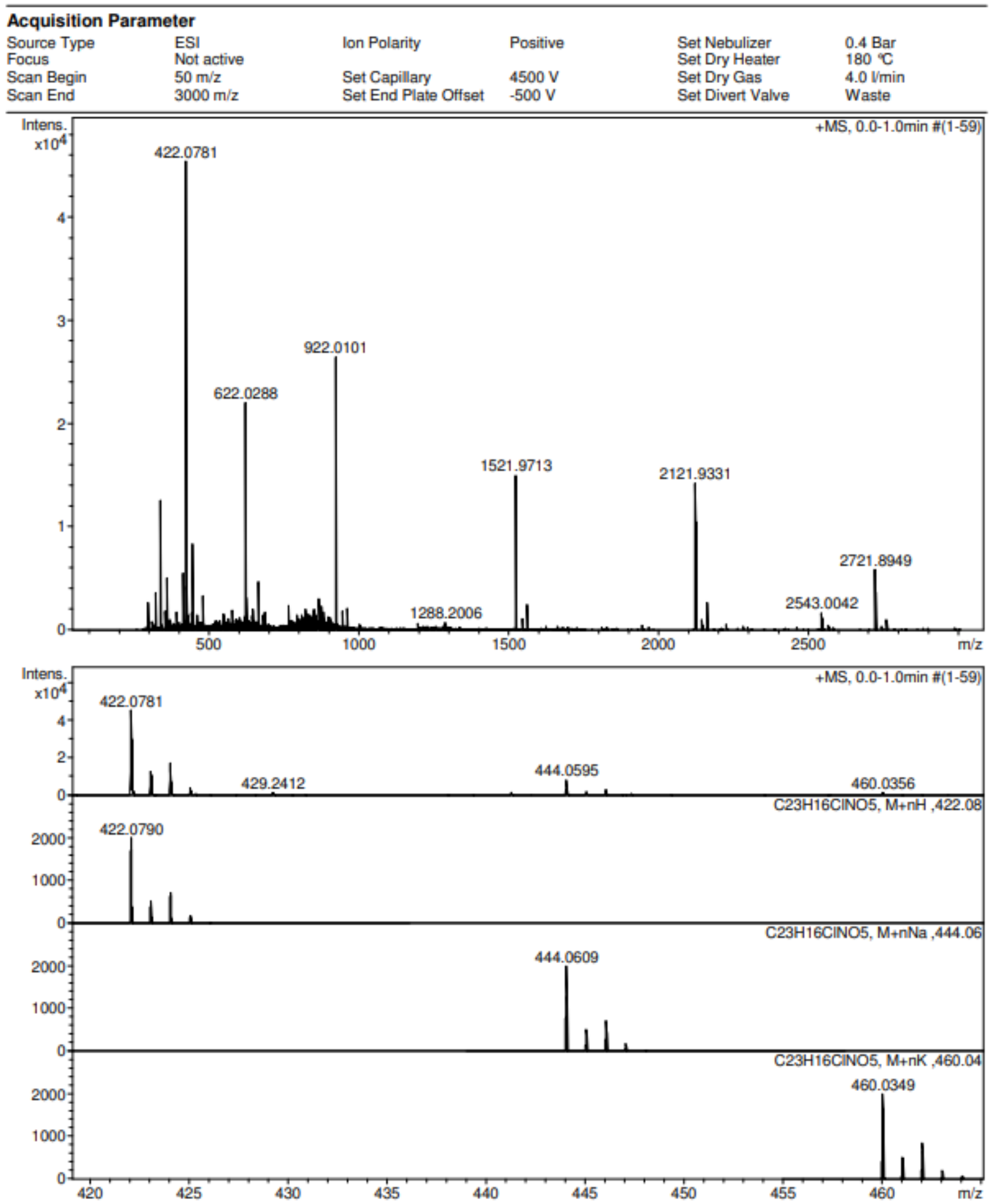


${ }^{1} \mathrm{H}$ NMR spectrum $\left(300 \mathrm{MHz}\right.$ ) of $15 \mathrm{e}$ in DMSO- $d_{6}$

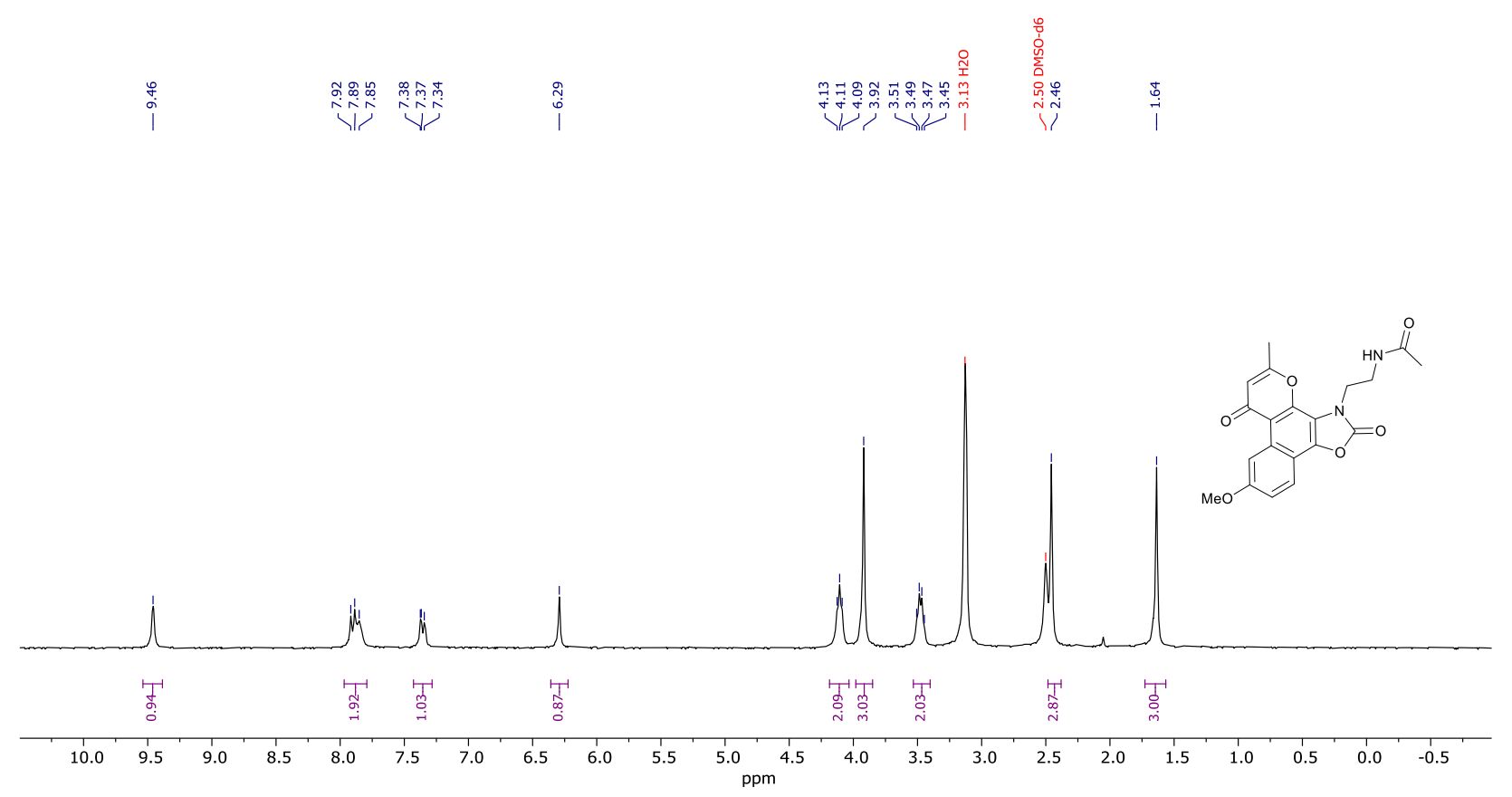

${ }^{13} \mathrm{C}\left\{{ }^{1} \mathrm{H}\right\}$ NMR spectrum $(126 \mathrm{MHz})$ of $15 \mathrm{e}$ in DMSO- $d_{6}$

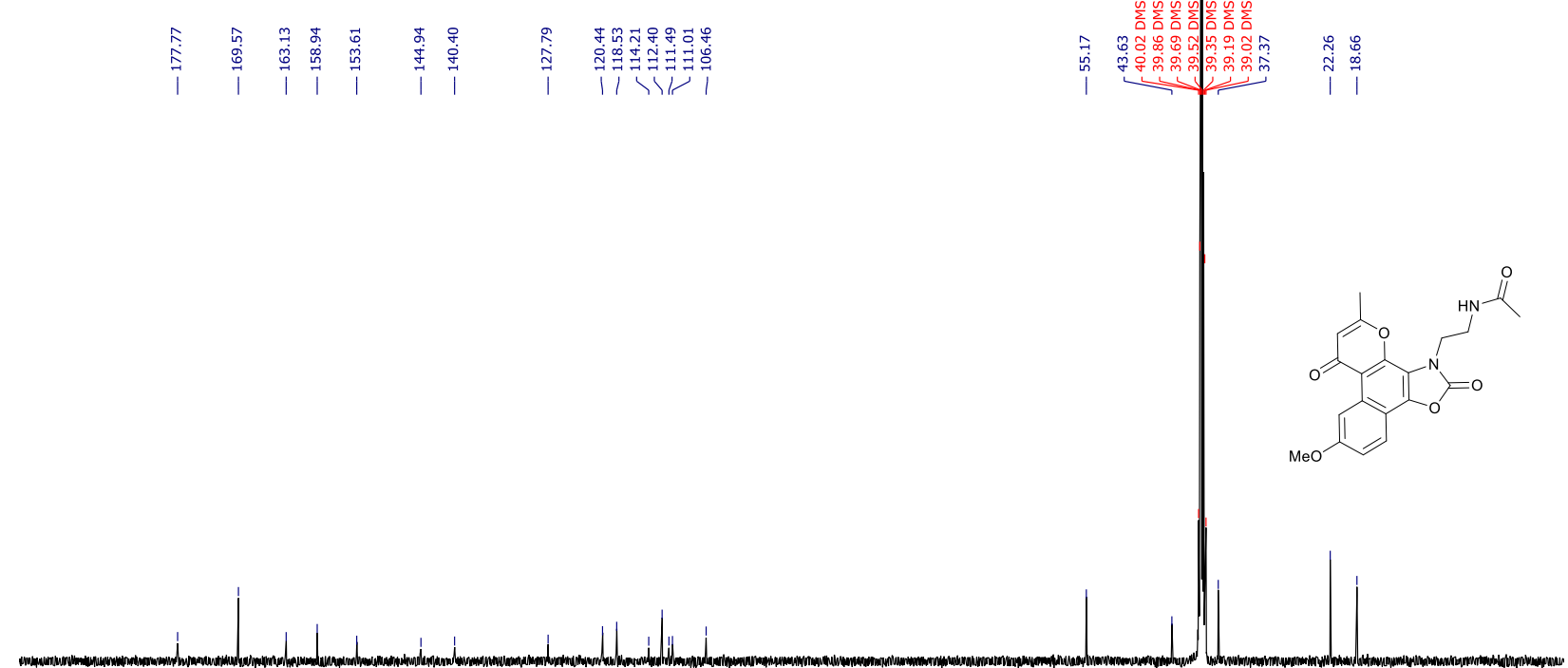

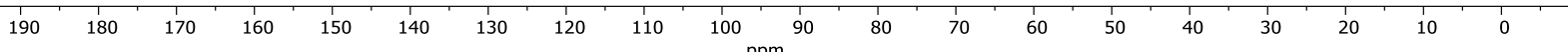


HRMS for compound 15e

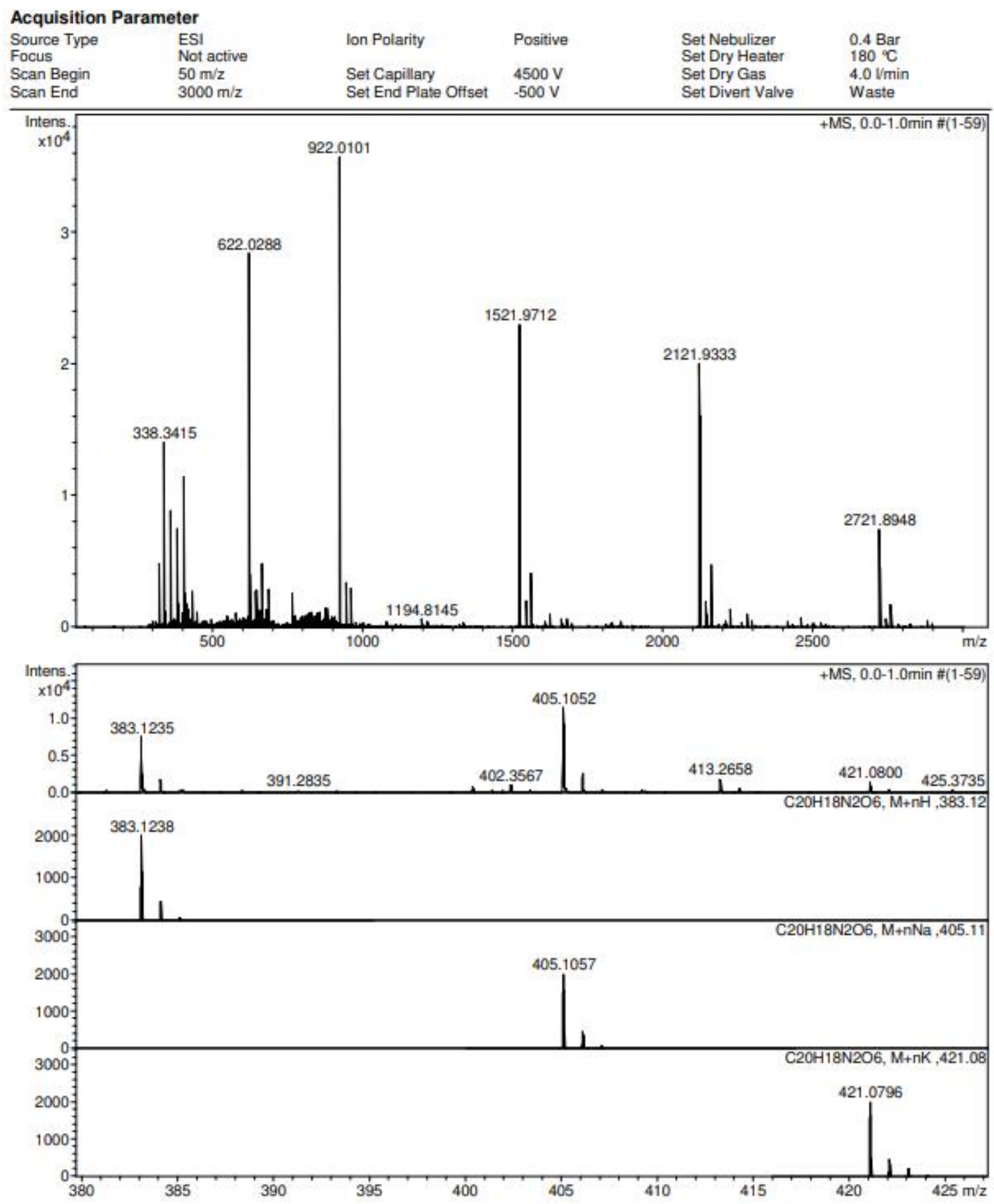


${ }^{1} \mathrm{H}$ NMR spectrum $\left(300 \mathrm{MHz}\right.$ ) of $\mathbf{1 5} \mathbf{f}$ in DMSO- $d_{6}$

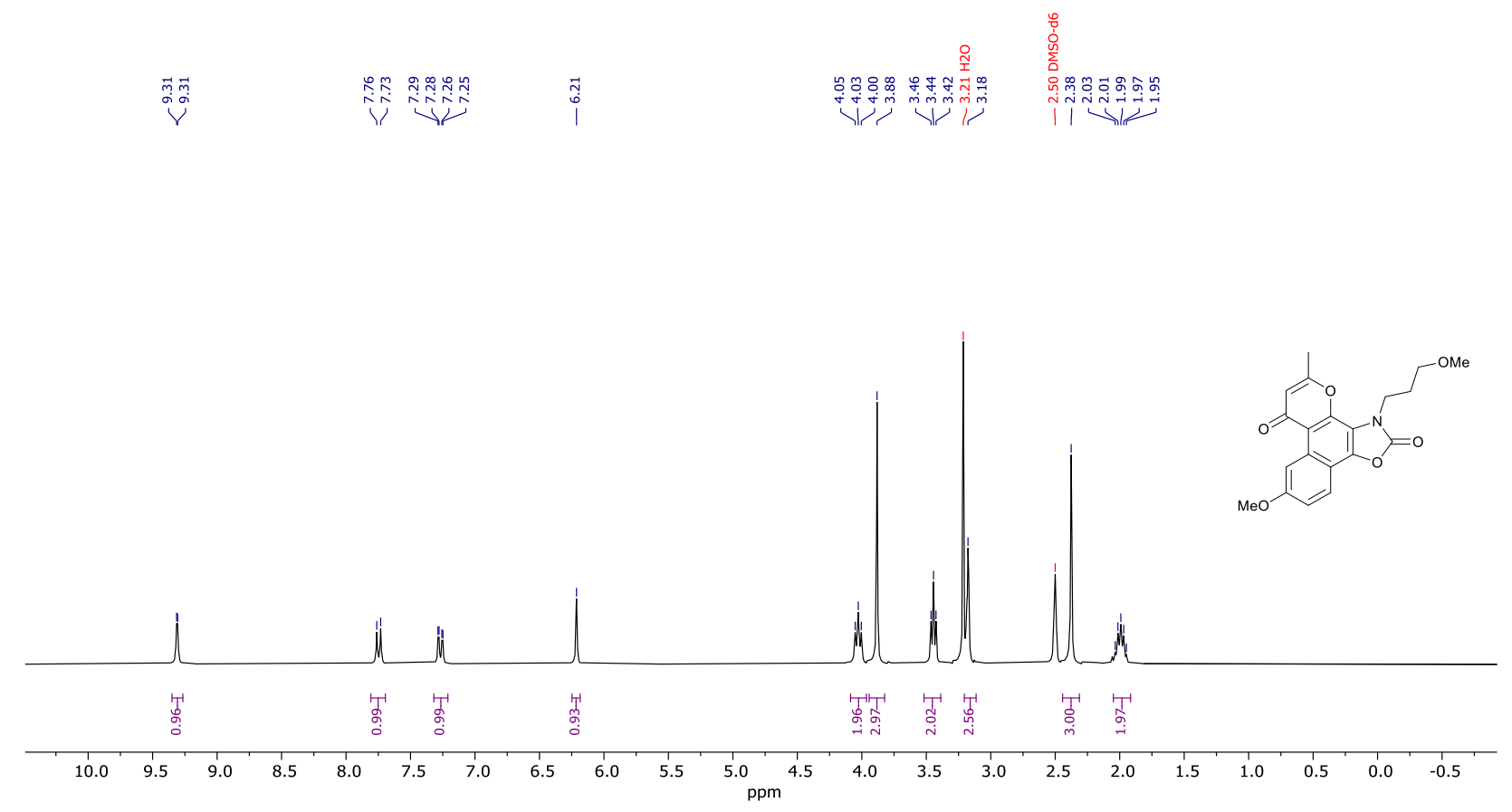

${ }^{13} \mathrm{C}\left\{{ }^{1} \mathrm{H}\right\}$ NMR spectrum (126 MHz) of $\mathbf{1 5 f}$ in DMSO-d

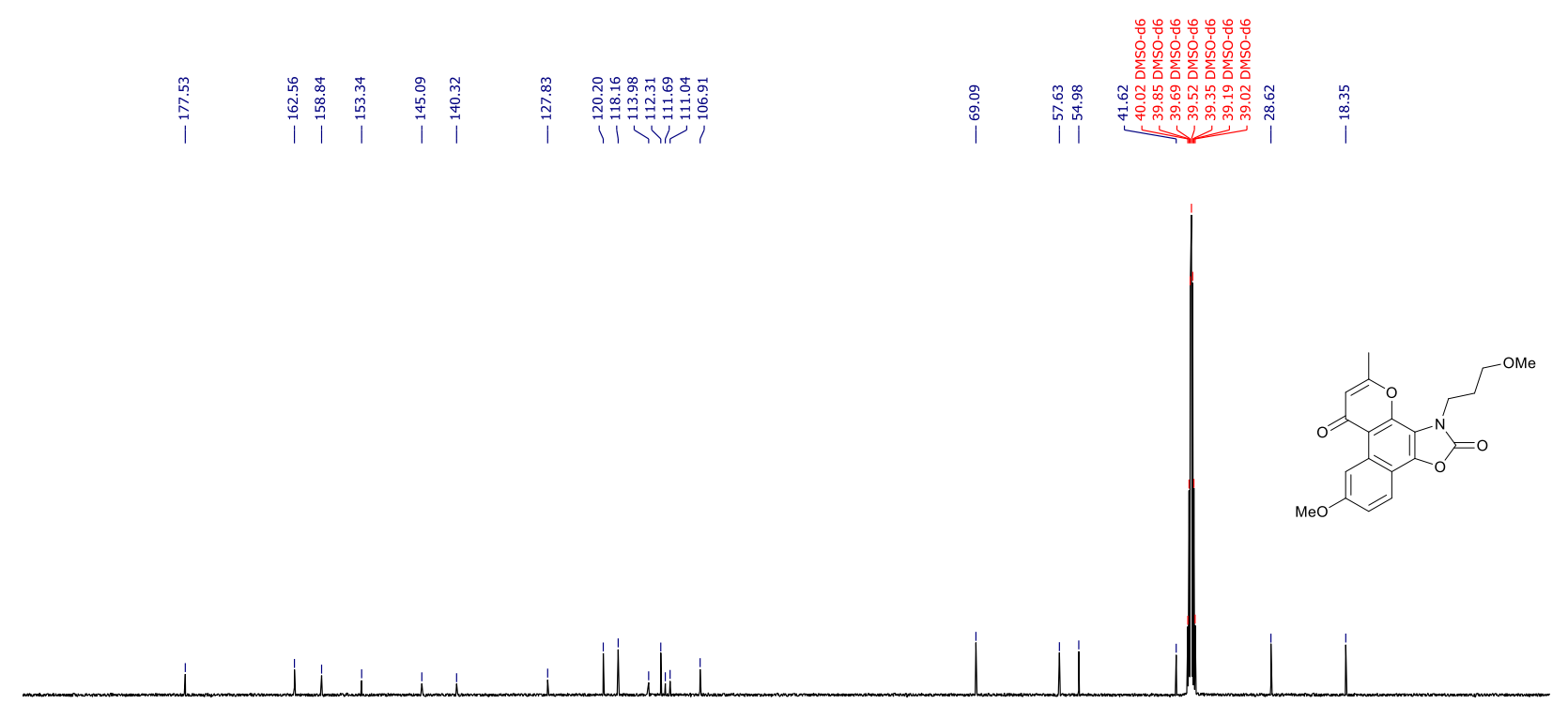

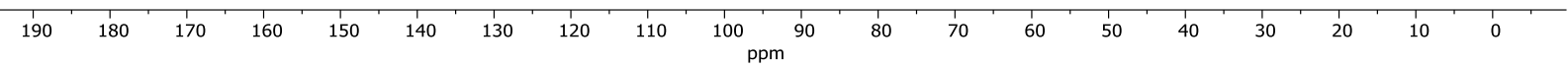


HRMS for compound $\mathbf{1 5 f}$

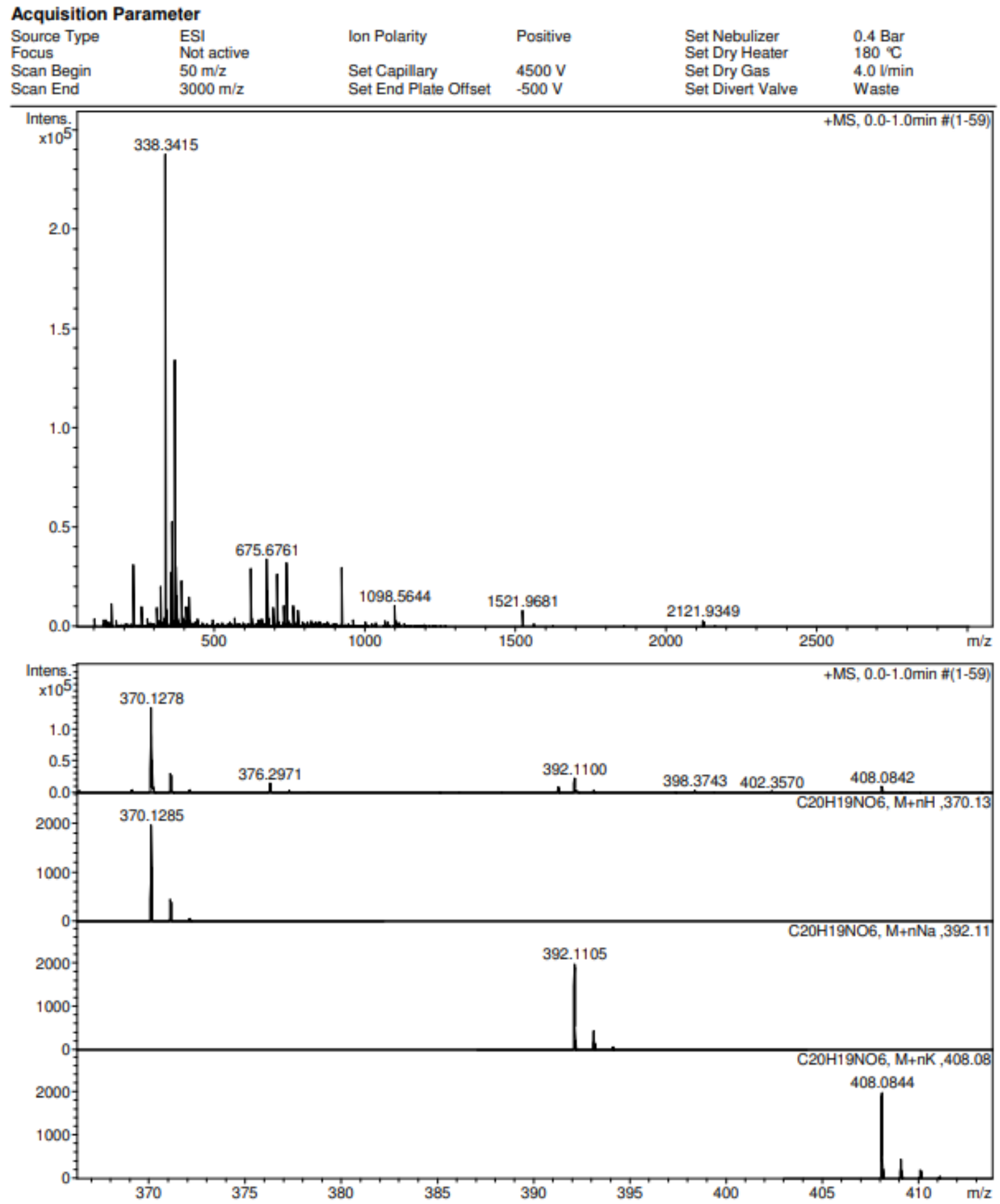


${ }^{1} \mathrm{H}$ NMR spectrum $\left(300 \mathrm{MHz}\right.$ ) of $15 \mathrm{~g}$ in DMSO- $d_{6}$

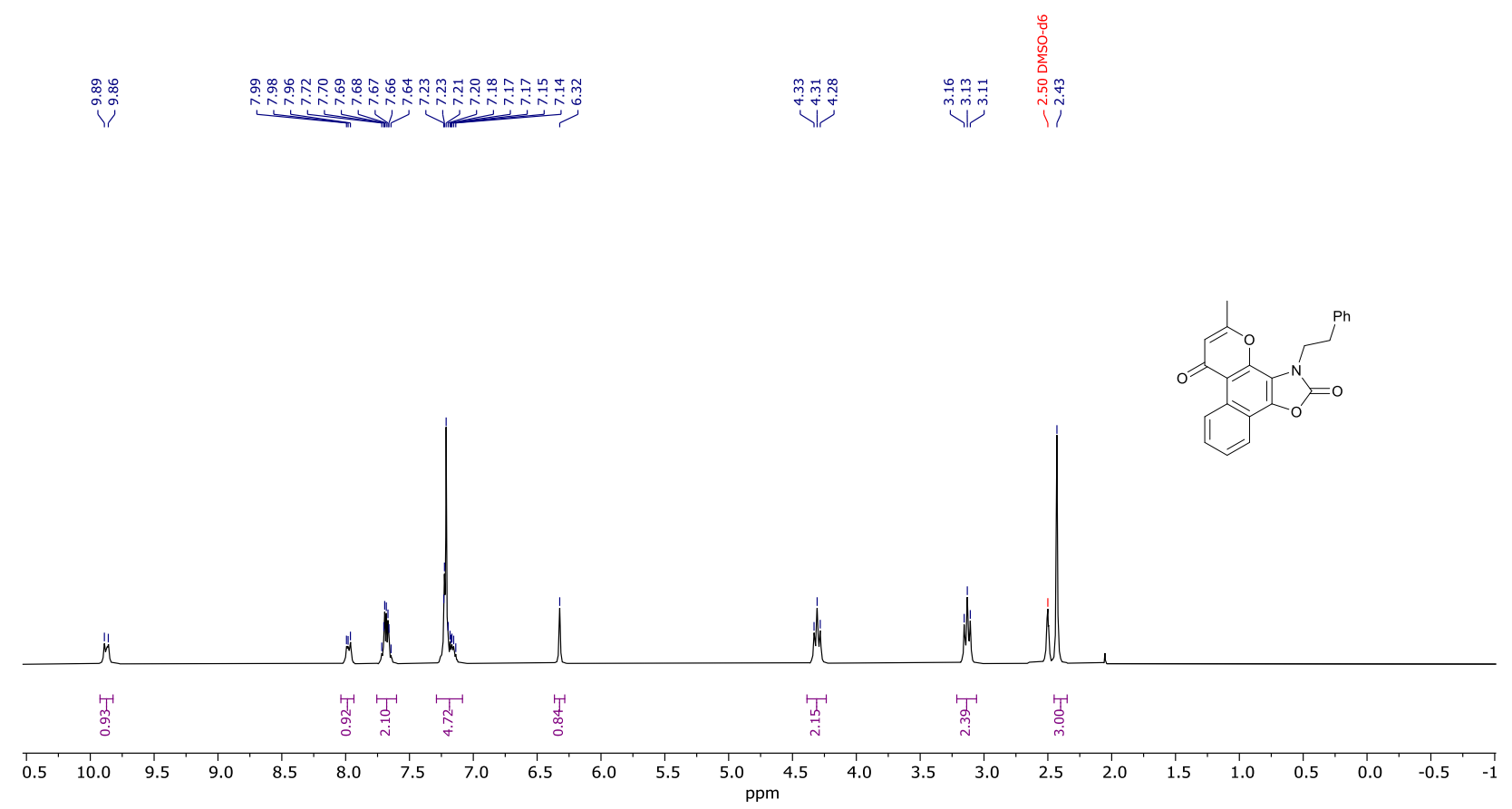

${ }^{13} \mathrm{C}\left\{{ }^{1} \mathrm{H}\right\}$ NMR spectrum $(126 \mathrm{MHz})$ of $15 \mathrm{~g}$ in DMSO- $d_{6}$

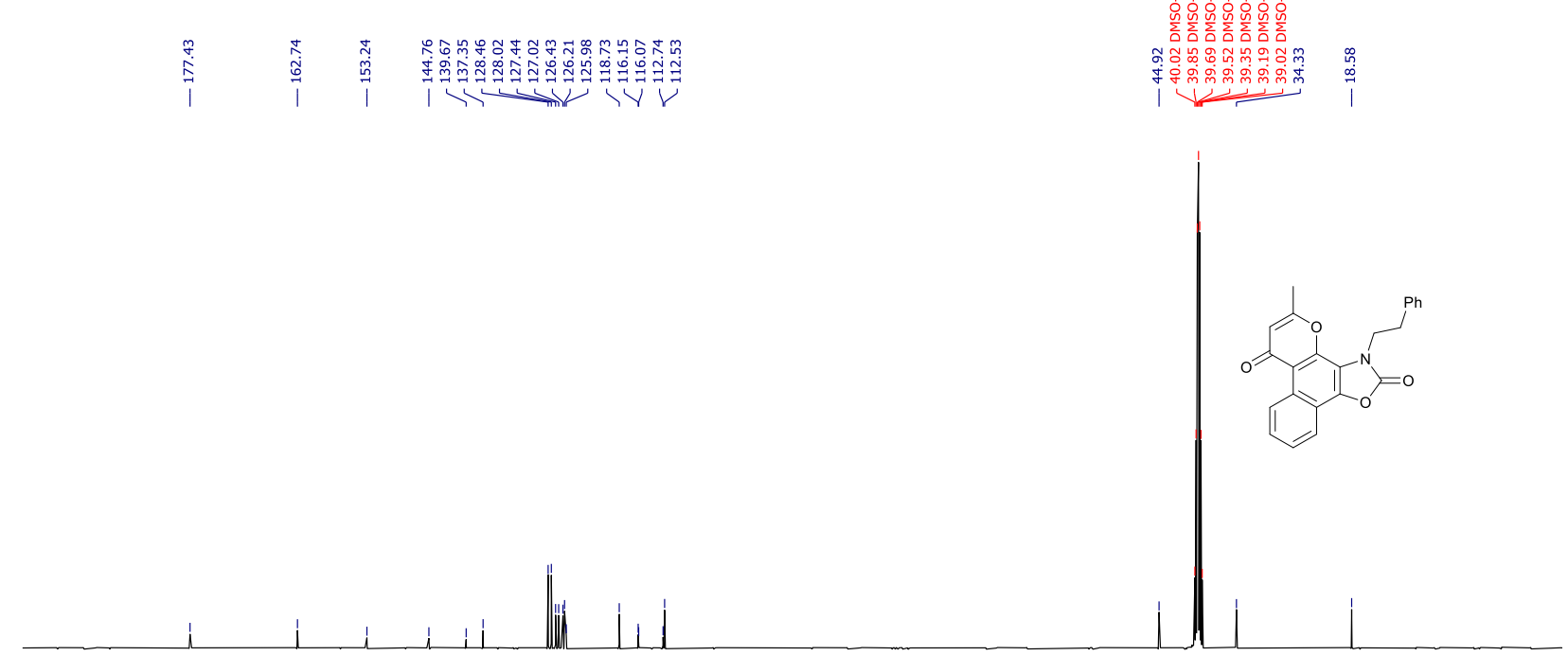

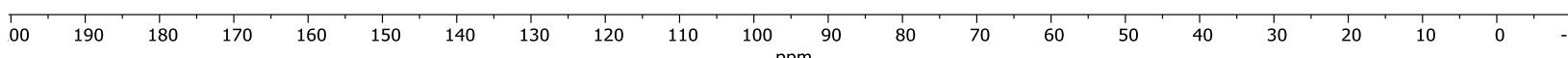


HRMS for compound 15g

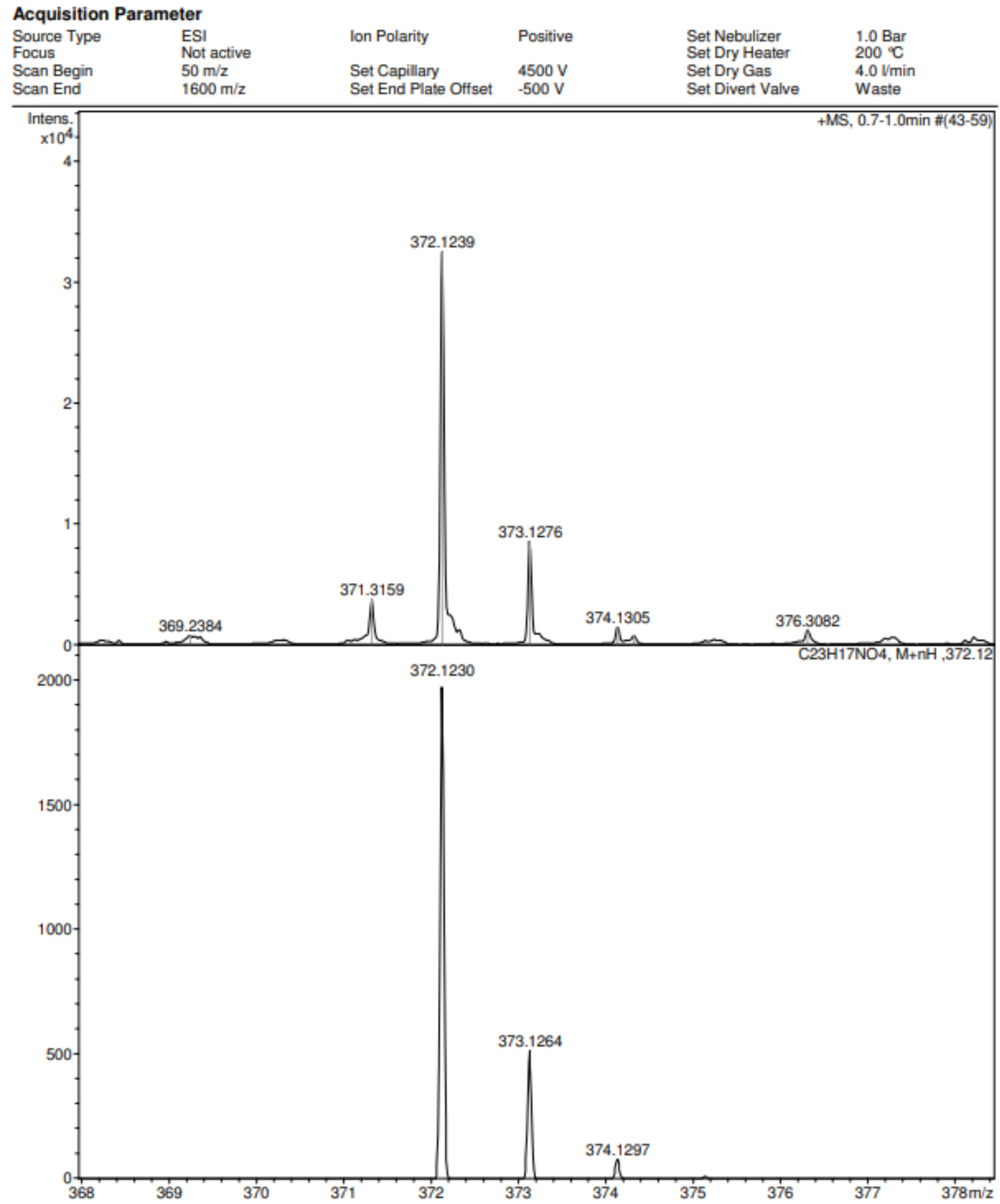


${ }^{1} \mathrm{H}$ NMR spectrum $(300 \mathrm{MHz})$ of $15 \mathrm{~h}$ in DMSO- $d_{6}$

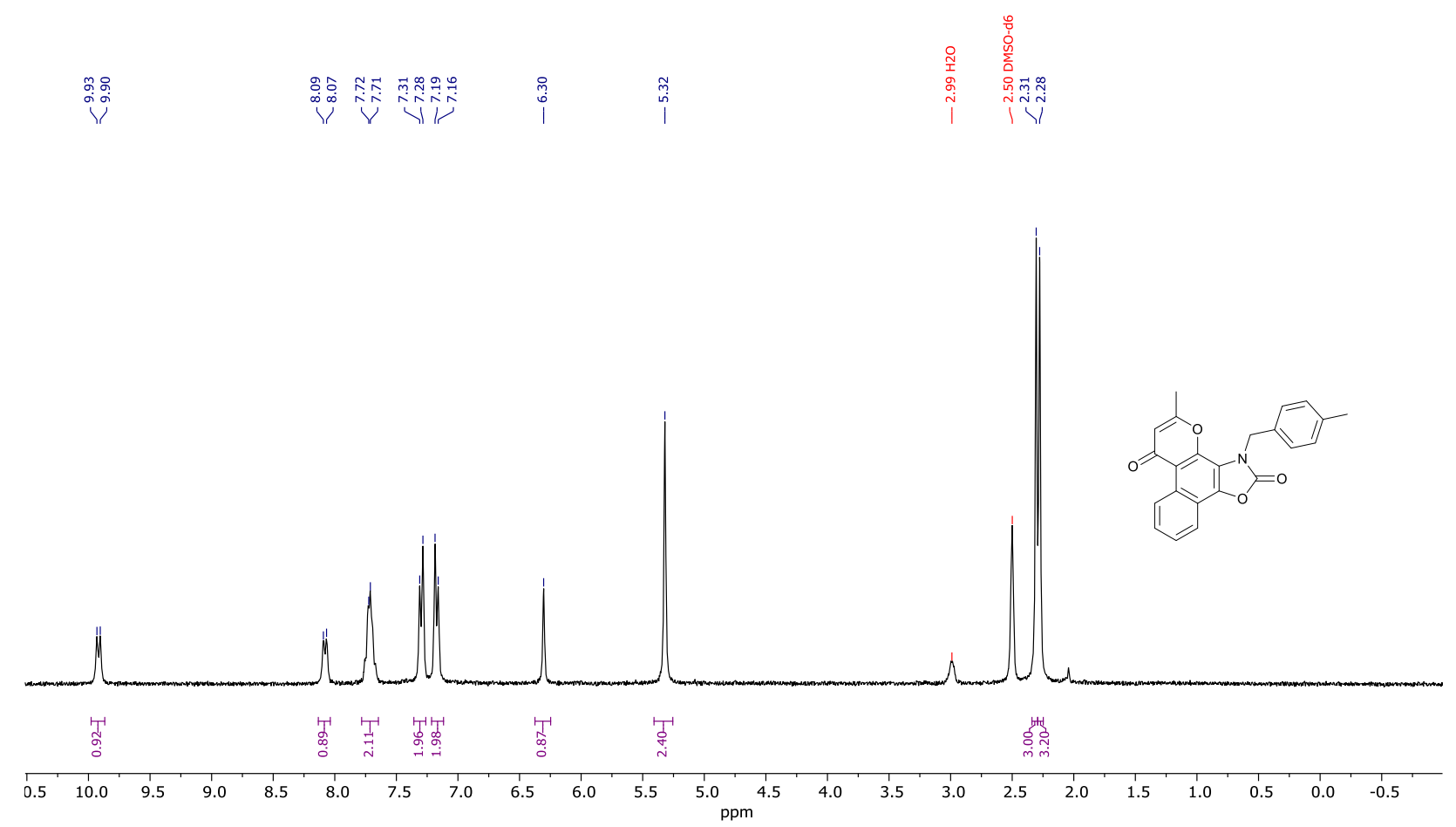

${ }^{13} \mathrm{C}\left\{{ }^{1} \mathrm{H}\right\}$ NMR spectrum $(101 \mathrm{MHz})$ of $15 \mathrm{~h}$ in DMSO- $d_{6}$

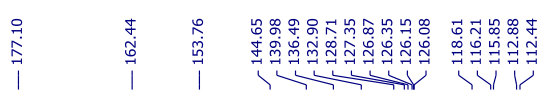

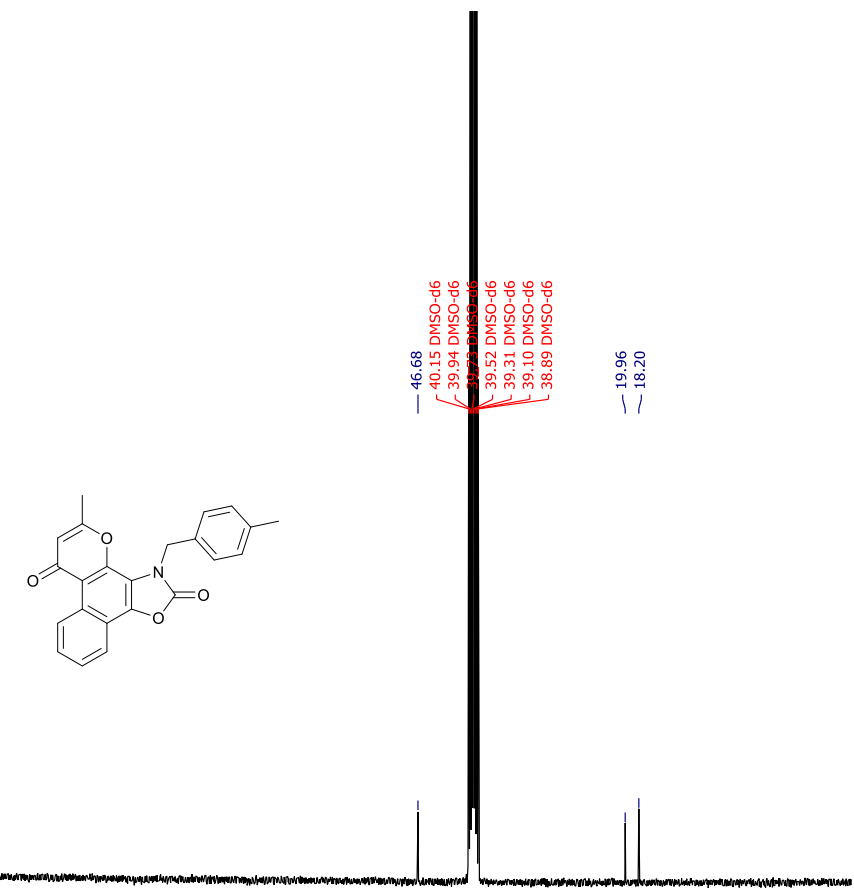

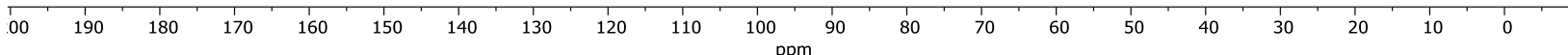


HRMS for compound $\mathbf{1 5 h}$

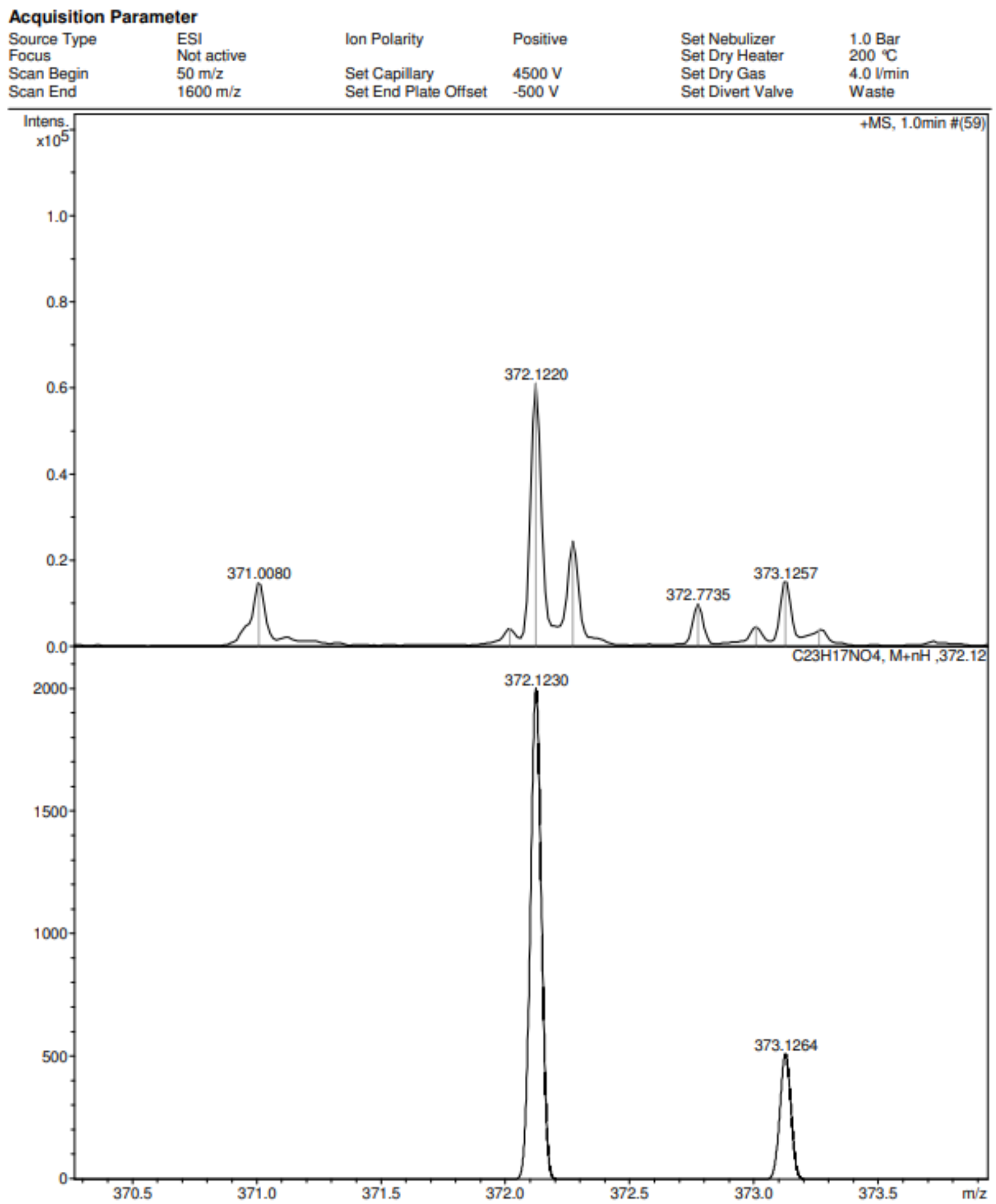


${ }^{1} \mathrm{H}$ NMR spectrum (300 MHz) of $\mathbf{1 5 i}$ in DMSO- $d_{6}$

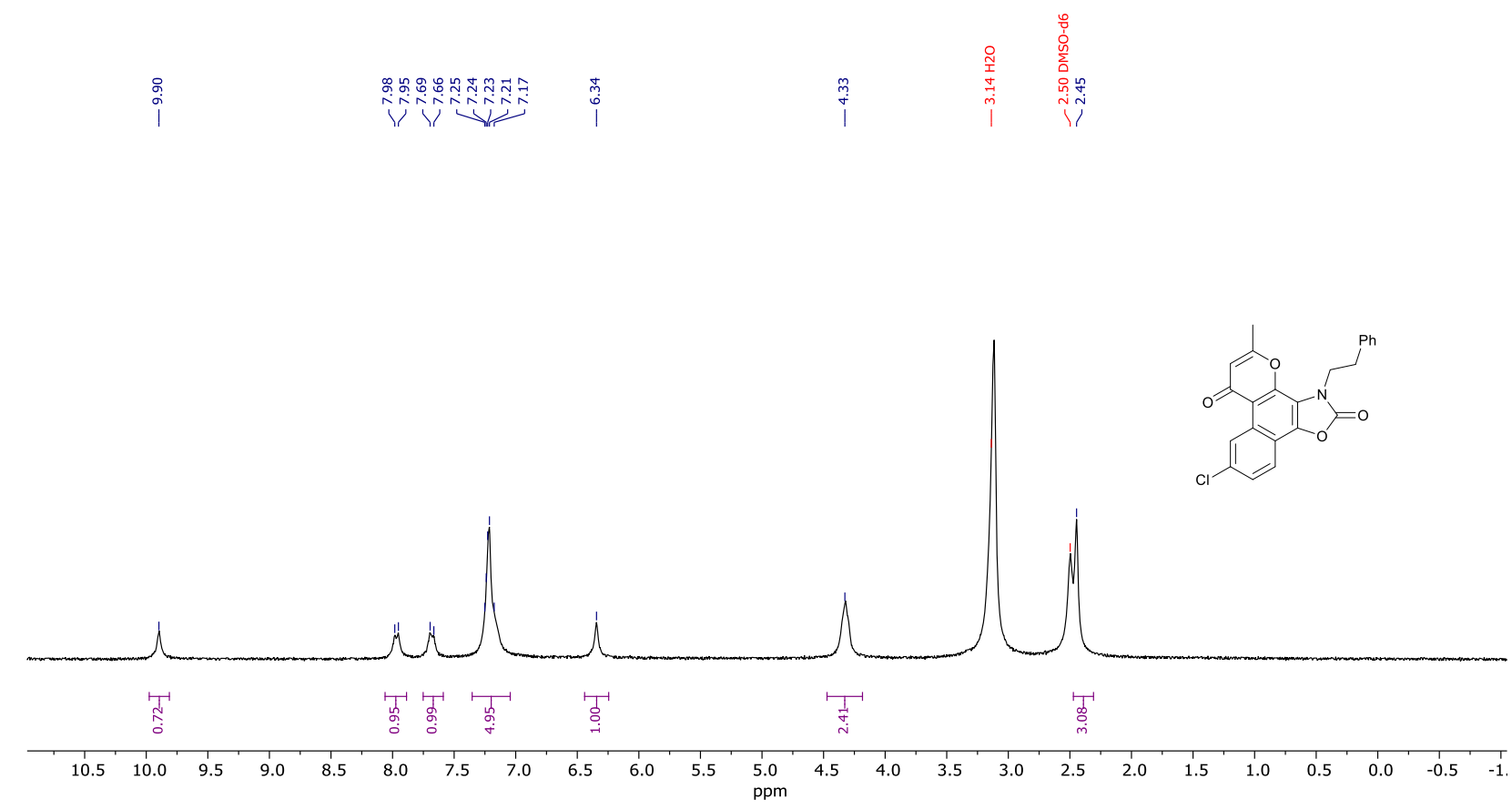

${ }^{13} \mathrm{C}\left\{{ }^{1} \mathrm{H}\right\}$ NMR spectrum $(126 \mathrm{MHz})$ of $15 \mathrm{i}$ in DMSO- $d_{6}$

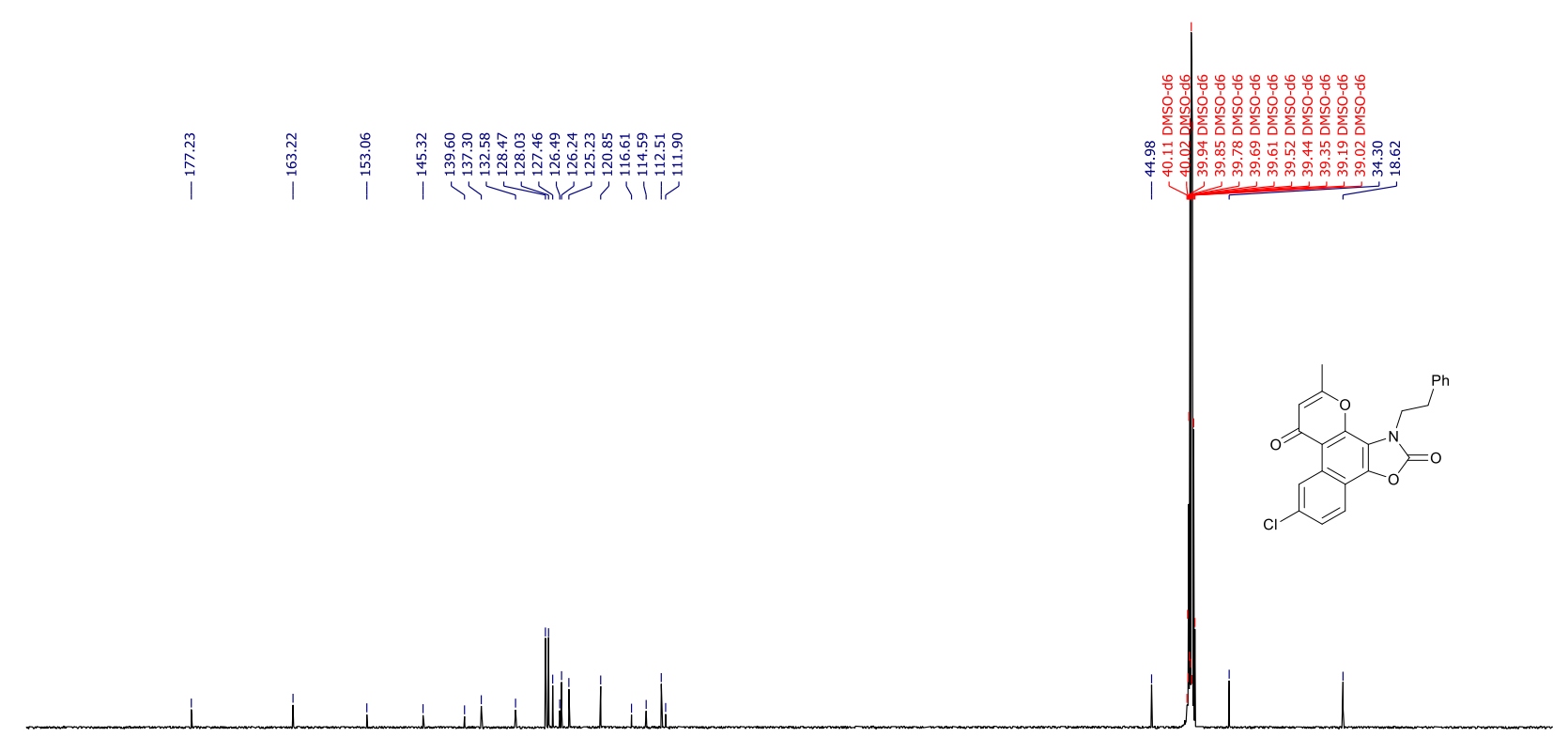

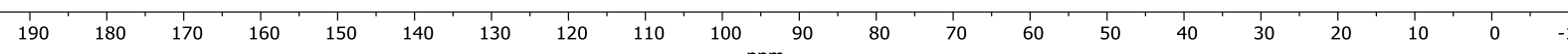


HRMS for compound $\mathbf{1 5} \mathbf{i}$

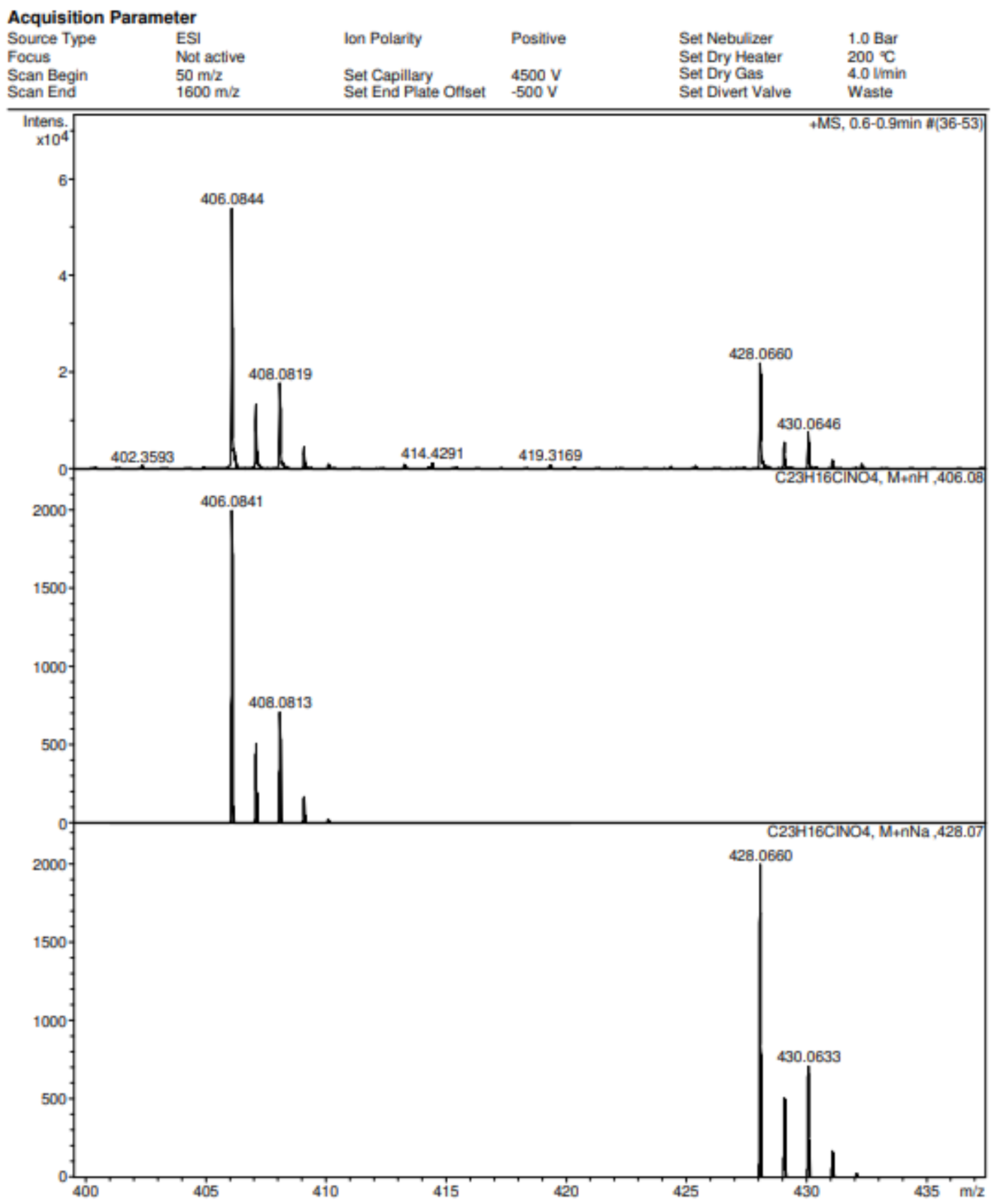


${ }^{1} \mathrm{H}$ NMR spectrum (300 MHz) of $\mathbf{1 5} \mathbf{j}$ in DMSO- $d_{6}$

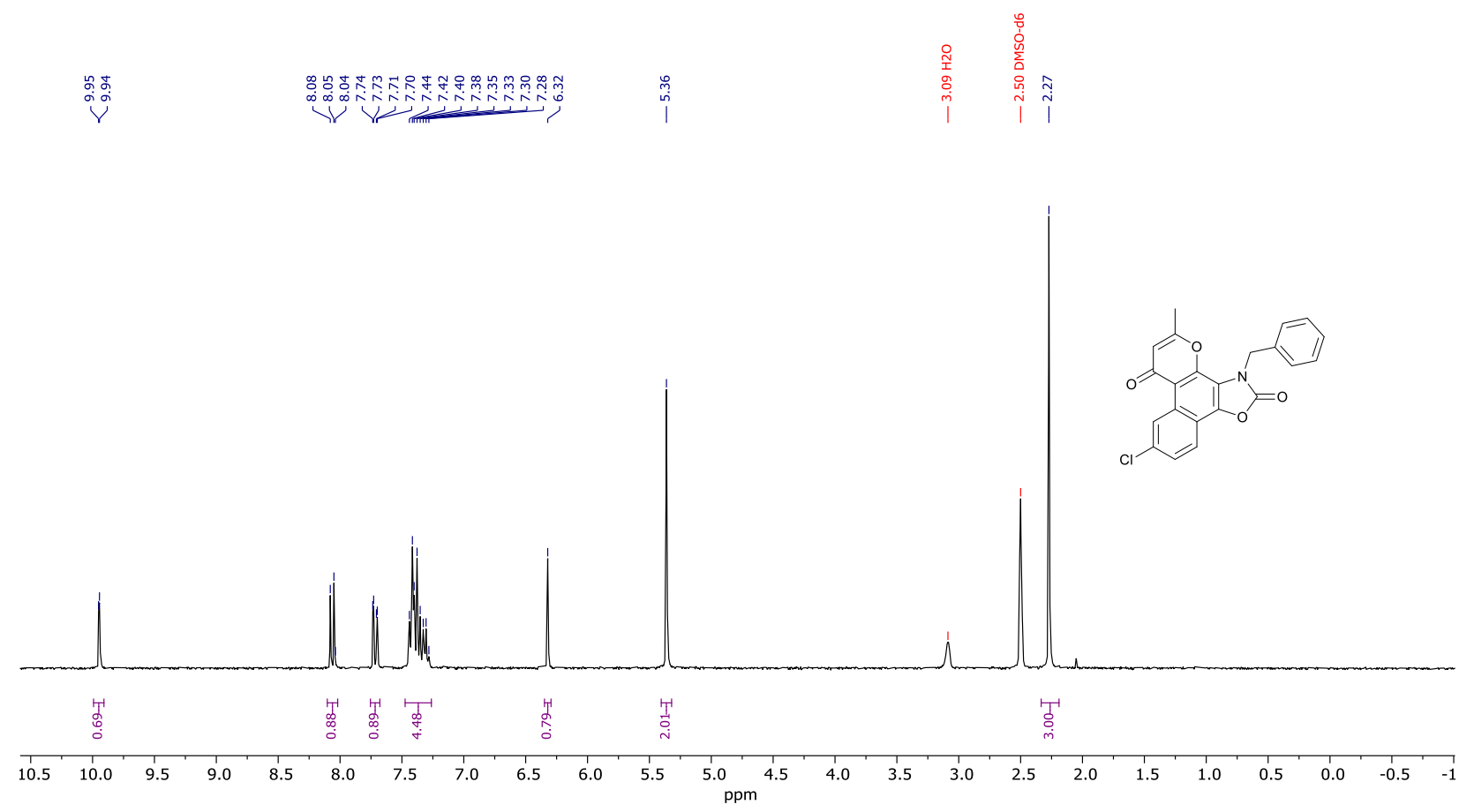

${ }^{13} \mathrm{C}\left\{{ }^{1} \mathrm{H}\right\}$ NMR spectrum (126 MHz) of 15j in DMSO- $d_{6}$

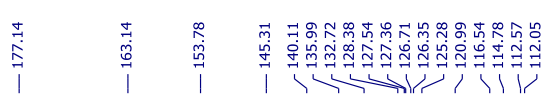
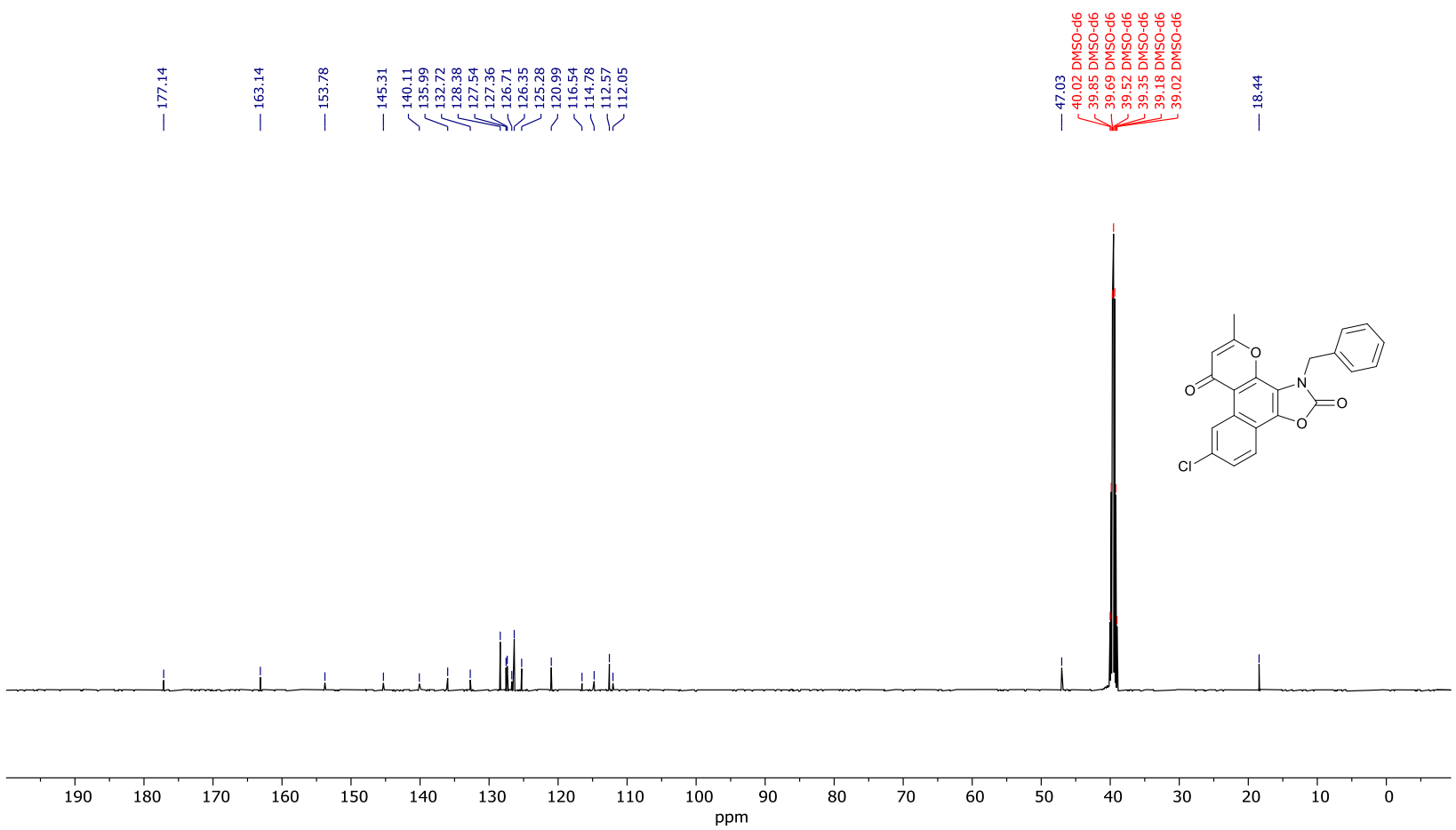
HRMS for compound $\mathbf{1 5 j}$

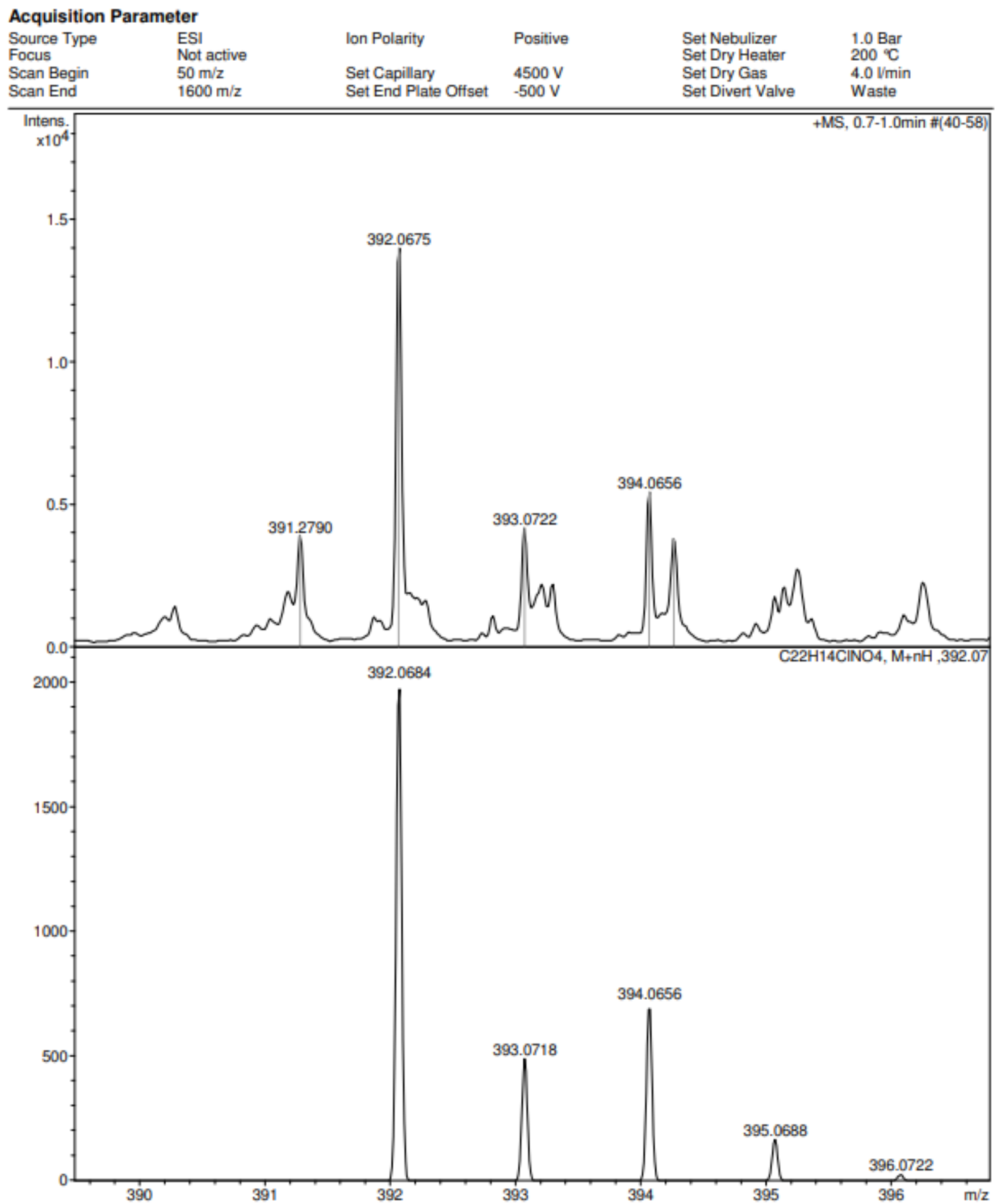


${ }^{1} \mathrm{H}$ NMR spectrum $\left(300 \mathrm{MHz}\right.$ ) of $\mathbf{1 5} \mathbf{k}$ in DMSO- $d_{6}$

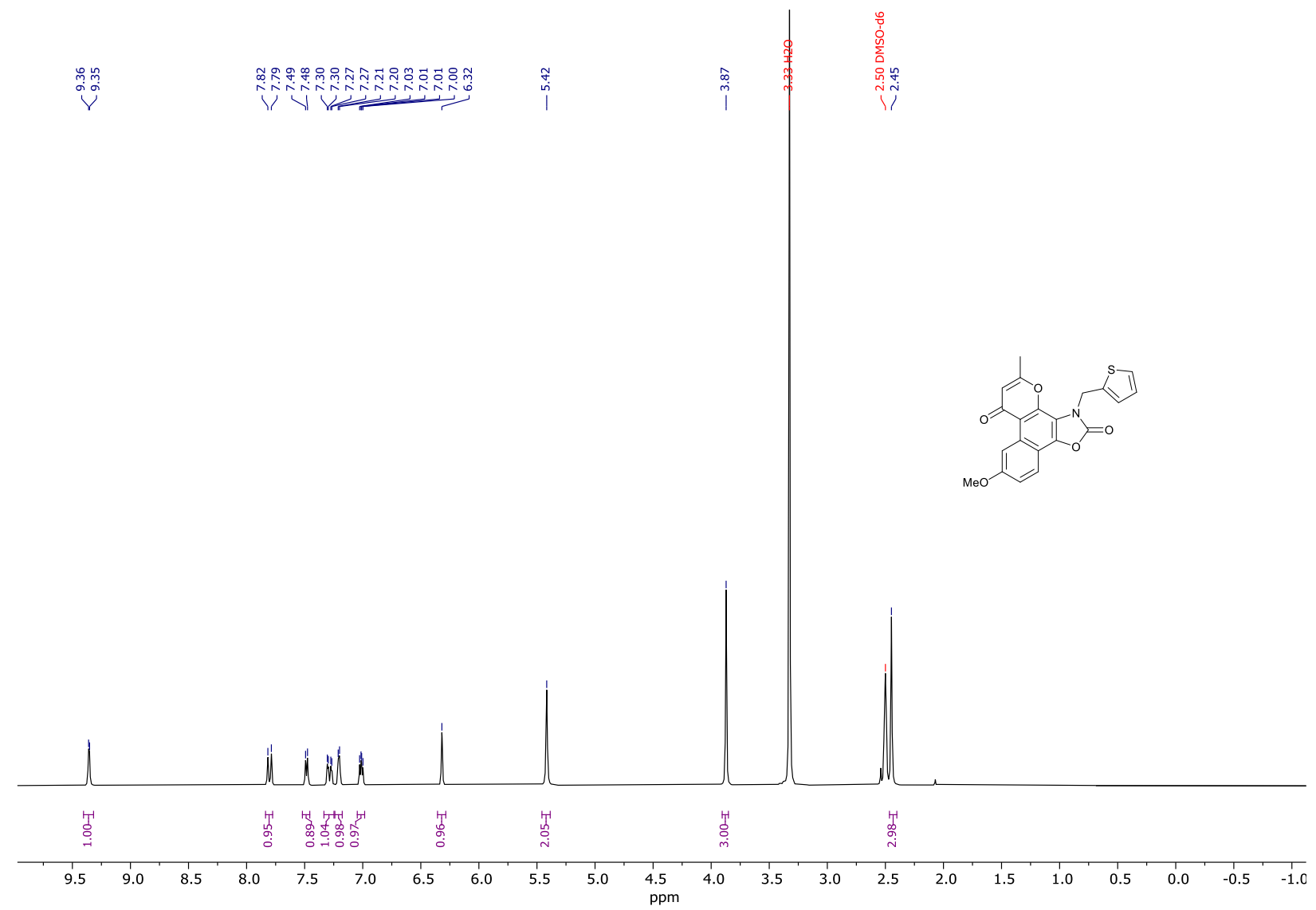

${ }^{13} \mathrm{C}\left\{{ }^{1} \mathrm{H}\right\}$ NMR spectrum $(75 \mathrm{MHz})$ of $15 k$ in DMSO- $d_{6}$

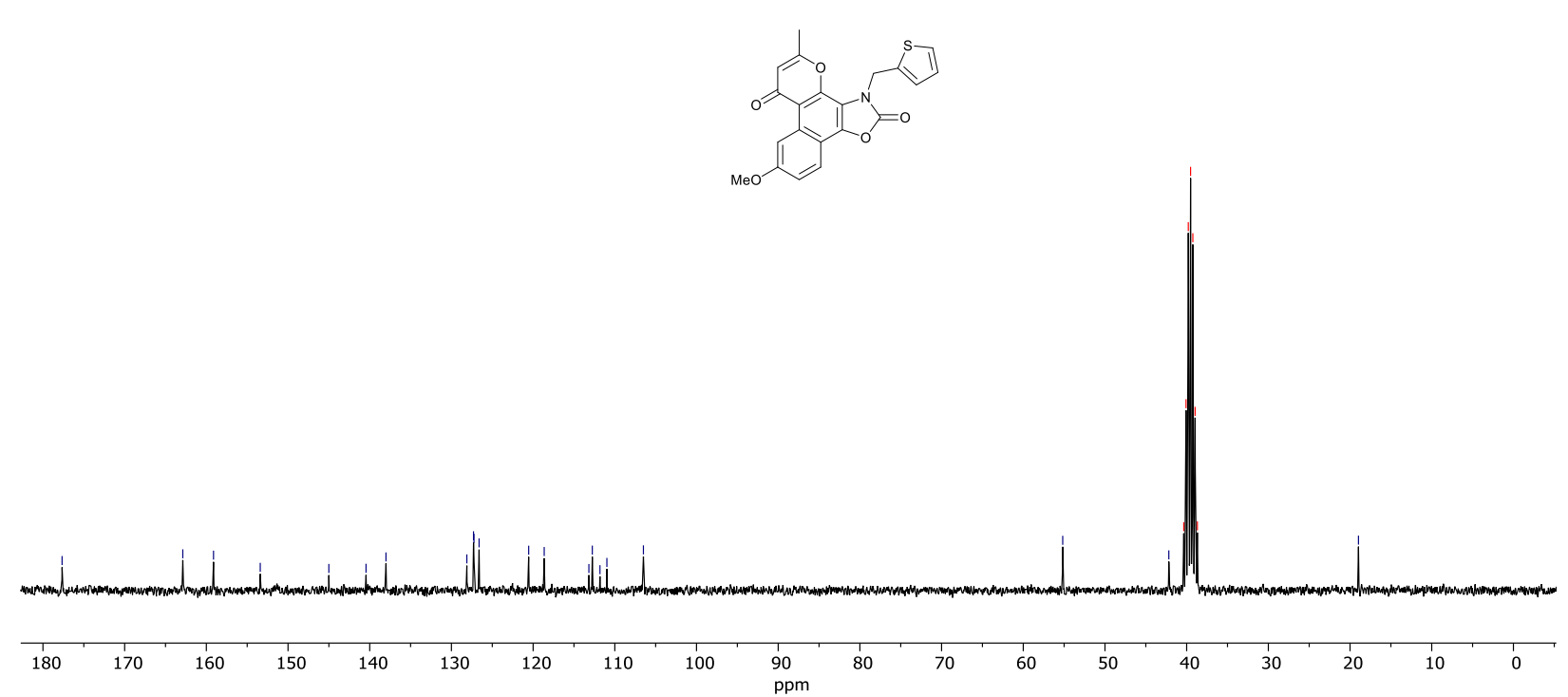


HRMS for compound 15k

Acquisition Parameter

Source Type ESI

Focus Not active

Scan Begin $\quad 50 \mathrm{~m} / \mathrm{z}$

Scan End $\quad 1600 \mathrm{~m} / \mathrm{z}$

$\begin{array}{llll}\text { Ion Polarity } & \text { Positive } & \text { Set Nebulizer } & 1.0 \mathrm{Bar} \\ & & \text { Set Dry Heater } & 200^{\circ} \mathrm{C} \\ \text { Set Capillary } & 4500 \mathrm{~V} & \text { Set Dry Gas } & 4.0 \mathrm{~V} / \mathrm{min} \\ \text { Set End Plate Offset } & -500 \mathrm{~V} & \text { Set Divert Valve } & \text { Waste }\end{array}$

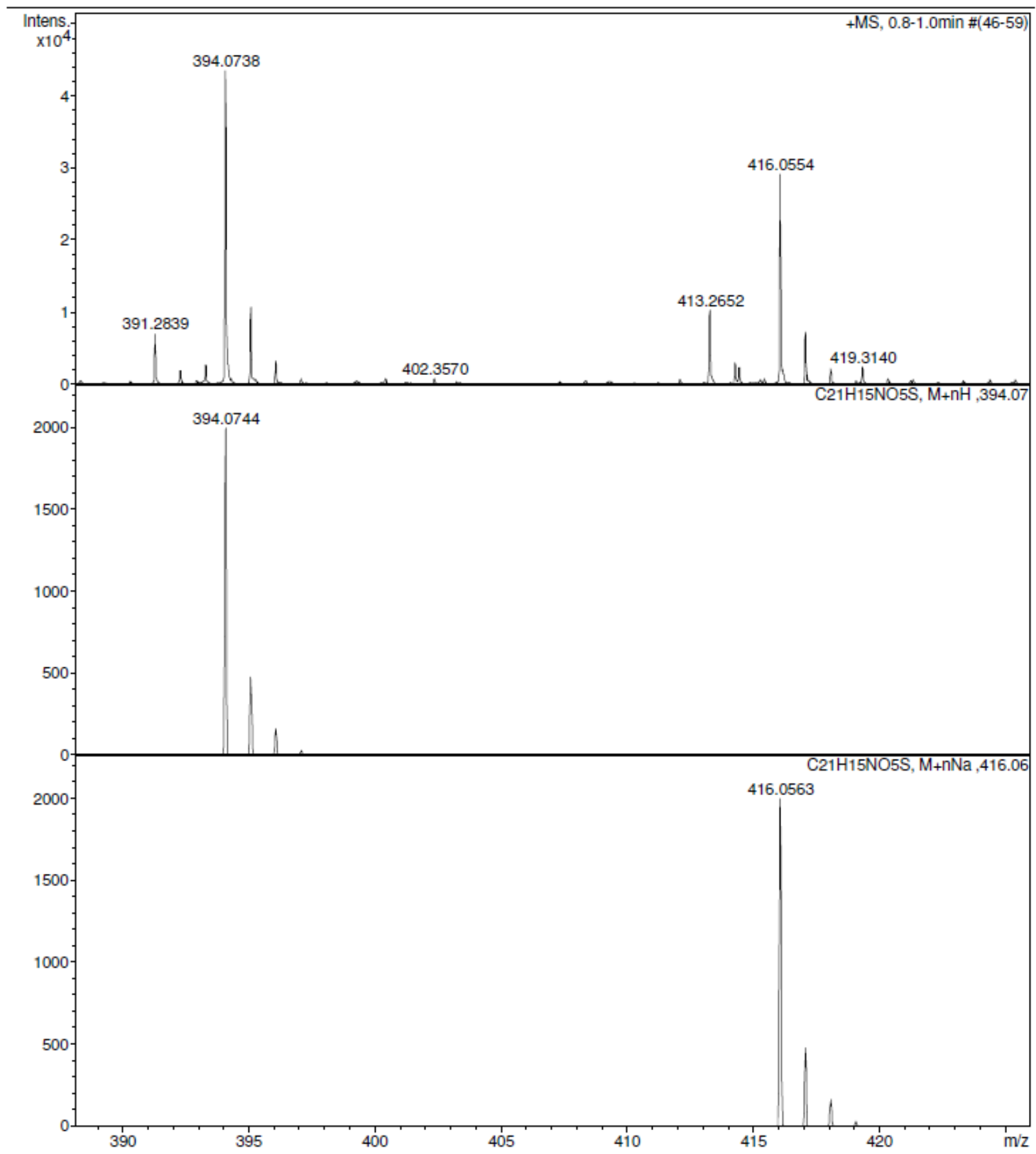


7. Copies of ${ }^{1} \mathrm{H},{ }^{13} \mathrm{C}$ NMR and HRMS for compounds 18.

${ }^{1} \mathrm{H}$ NMR spectrum $\left(300 \mathrm{MHz}\right.$ ) of $18 \mathrm{a}$ in DMSO- $d_{6}$

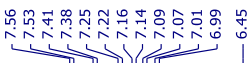

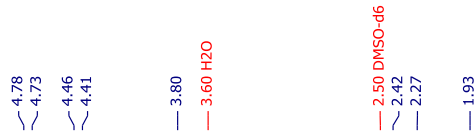

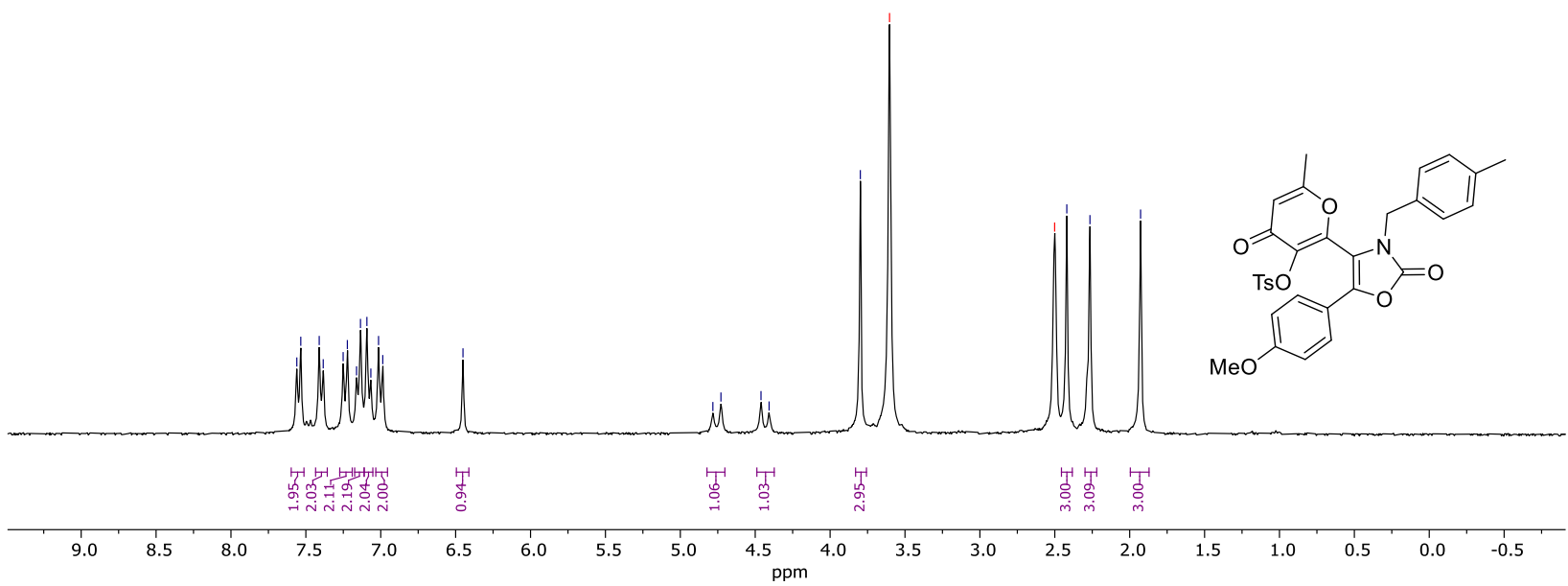

${ }^{13} \mathrm{C}\left\{{ }^{1} \mathrm{H}\right\}$ NMR spectrum (126 MHz) of 18a in DMSO- $d_{6}$

œ ๓

i.
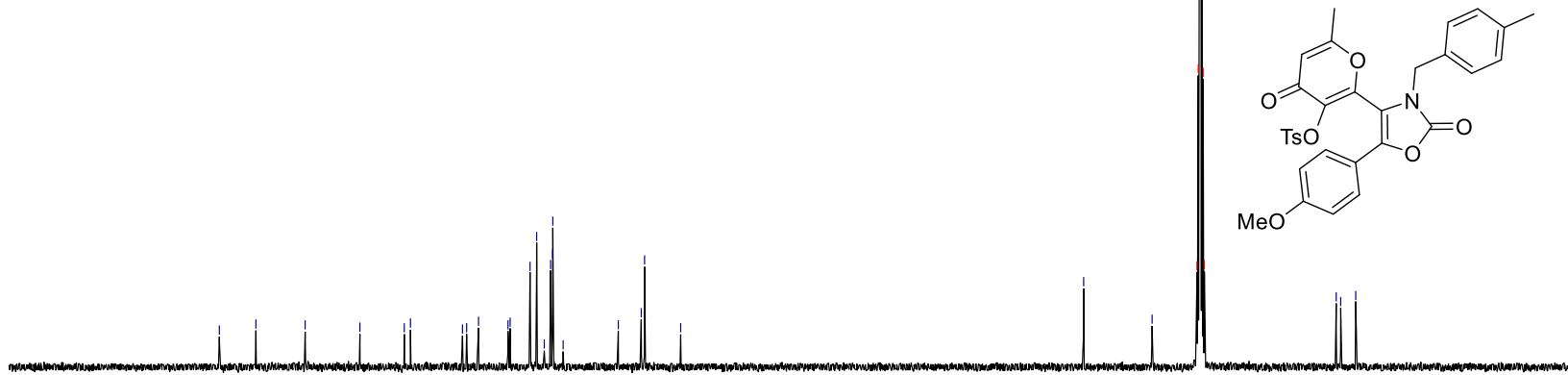

\begin{tabular}{lllllllllllllllllllllll}
\hline 0 & 190 & 180 & 170 & 160 & 150 & 140 & 130 & 120 & 110 & 100 & 90 & 80 & 70 & 60 & 50 & 40 & 30 & 20 & 10 & 0 & -1
\end{tabular} 
HRMS for compound 18a

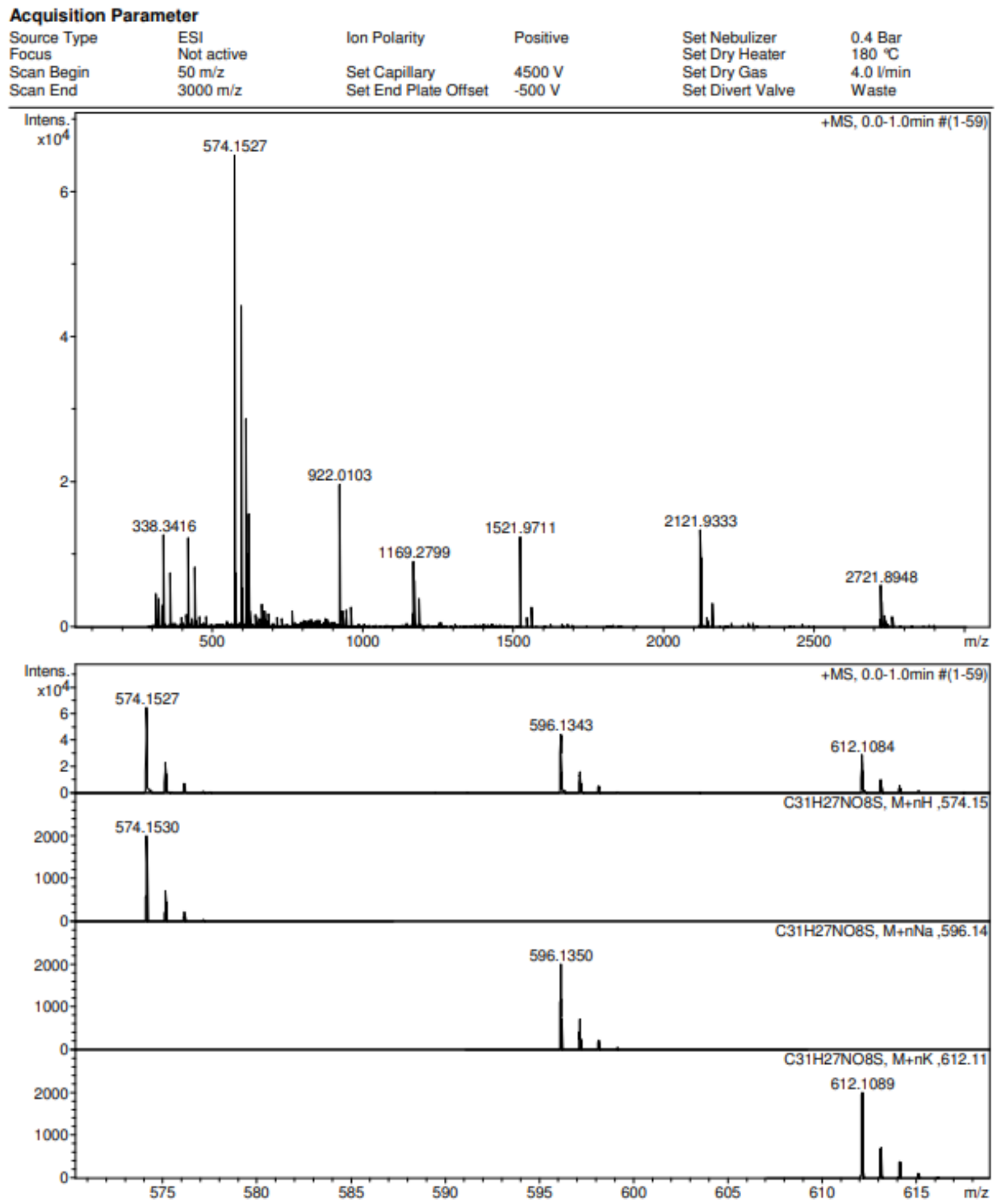


${ }^{1} \mathrm{H}$ NMR spectrum $\left(300 \mathrm{MHz}\right.$ ) of $\mathbf{1 8} \mathbf{b}$ in DMSO- $d_{6}$

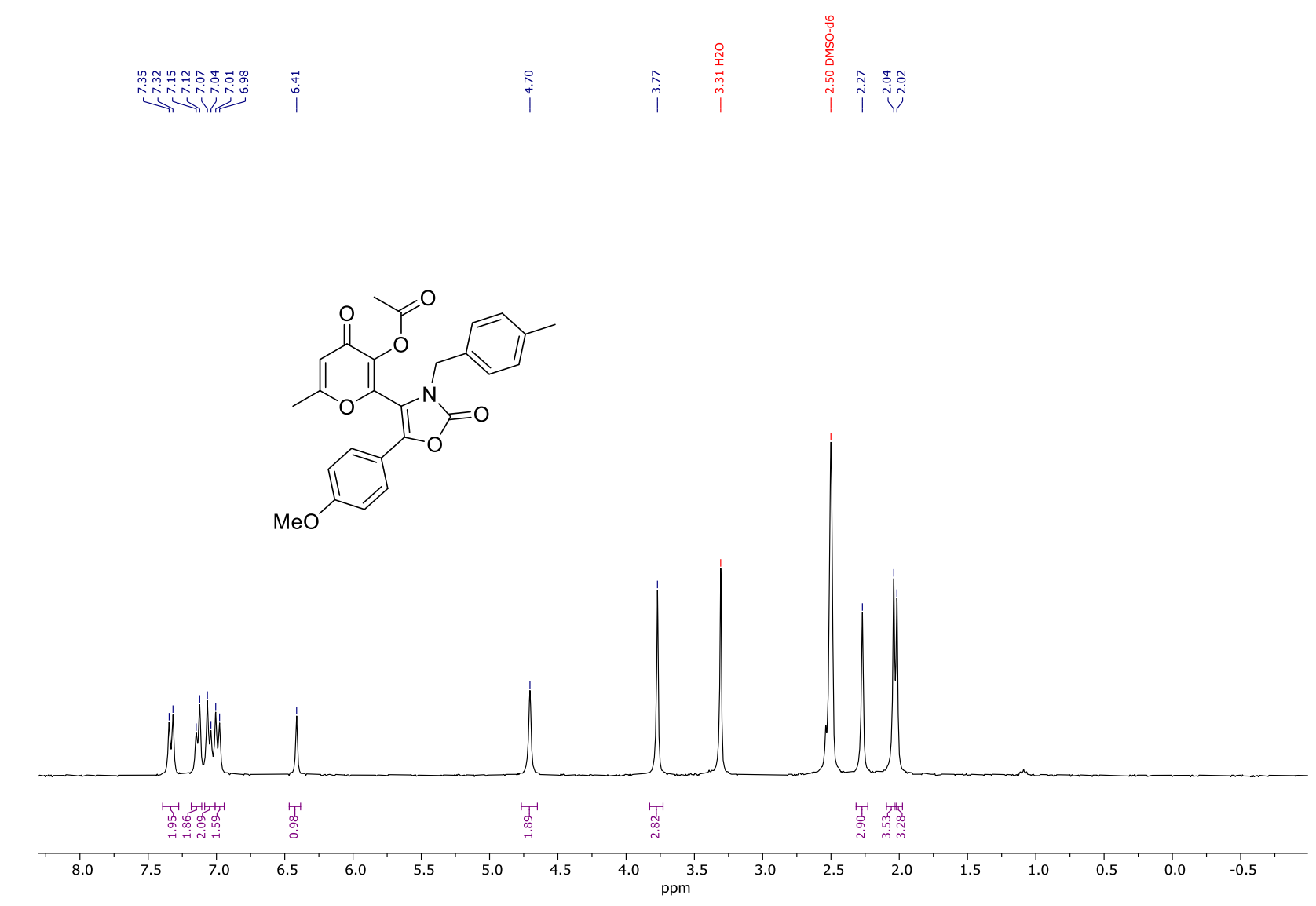

${ }^{13} \mathrm{C}\left\{{ }^{1} \mathrm{H}\right\}$ NMR spectrum (75 MHz) of $18 \mathbf{b}$ in DMSO- $d_{6}$

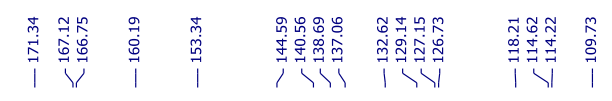
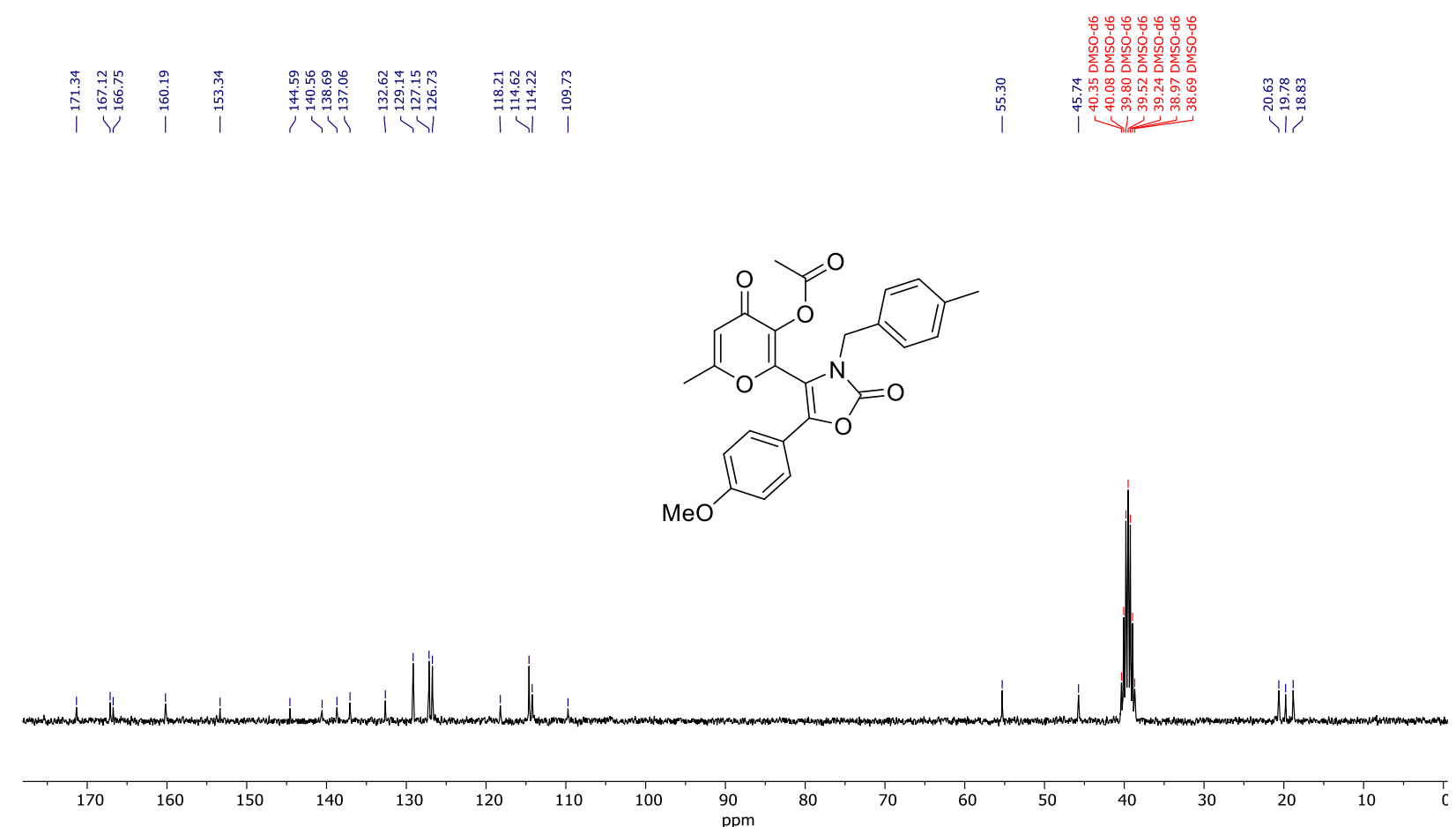
HRMS for compound $\mathbf{1 8 b}$

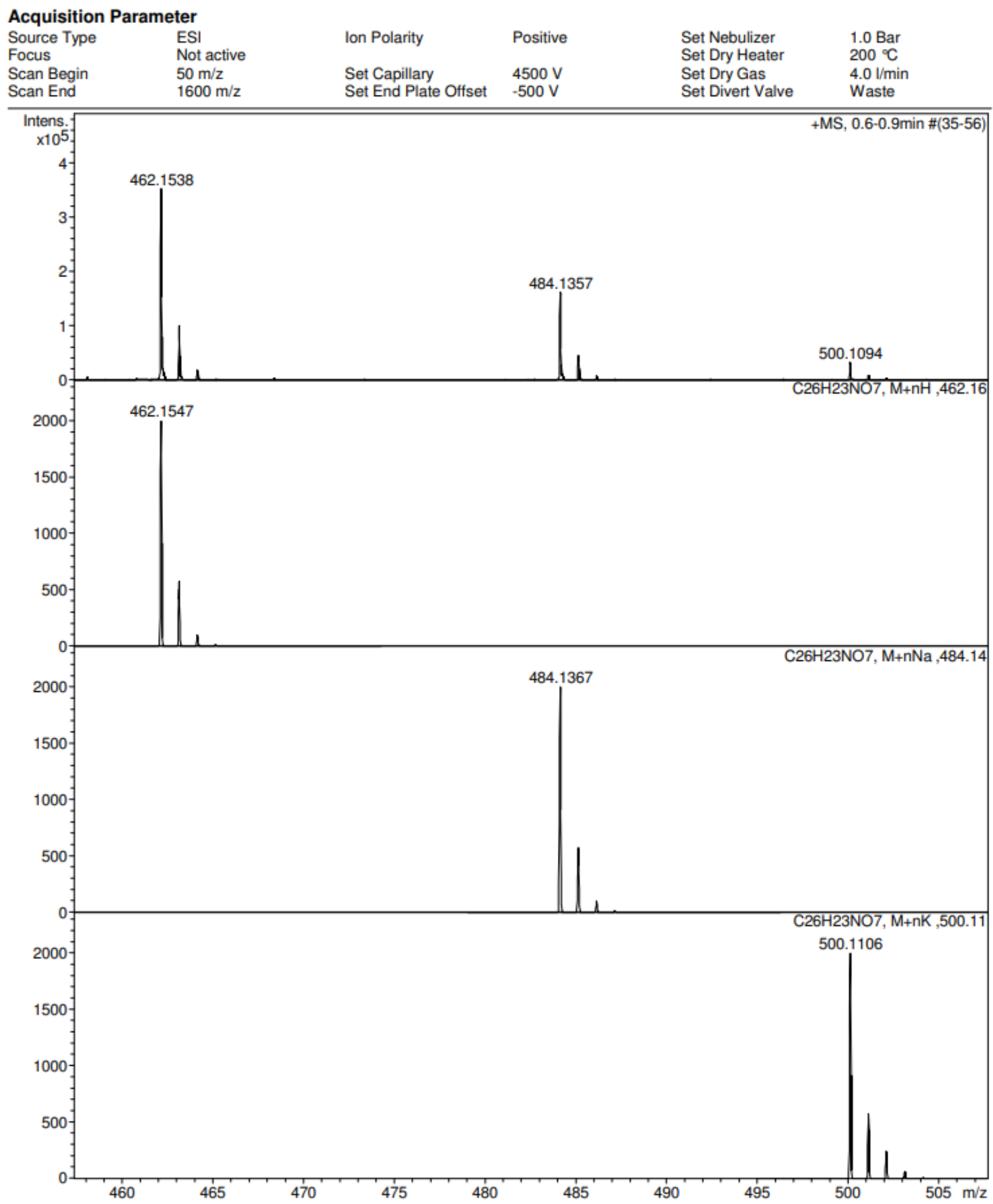


${ }^{1} \mathrm{H}$ NMR spectrum (300 MHz) of $18 \mathrm{c}$ in DMSO- $d_{6}$

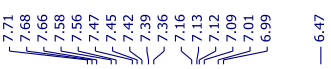

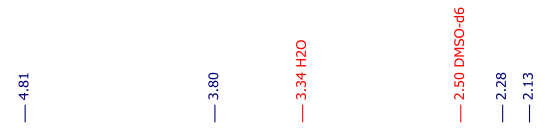<smiles>COc1ccc(-c2oc(=O)n(Cc3ccc(C)cc3)c2-c2oc(C)cc(=O)c2OC(=O)c2ccccc2)cc1</smiles>

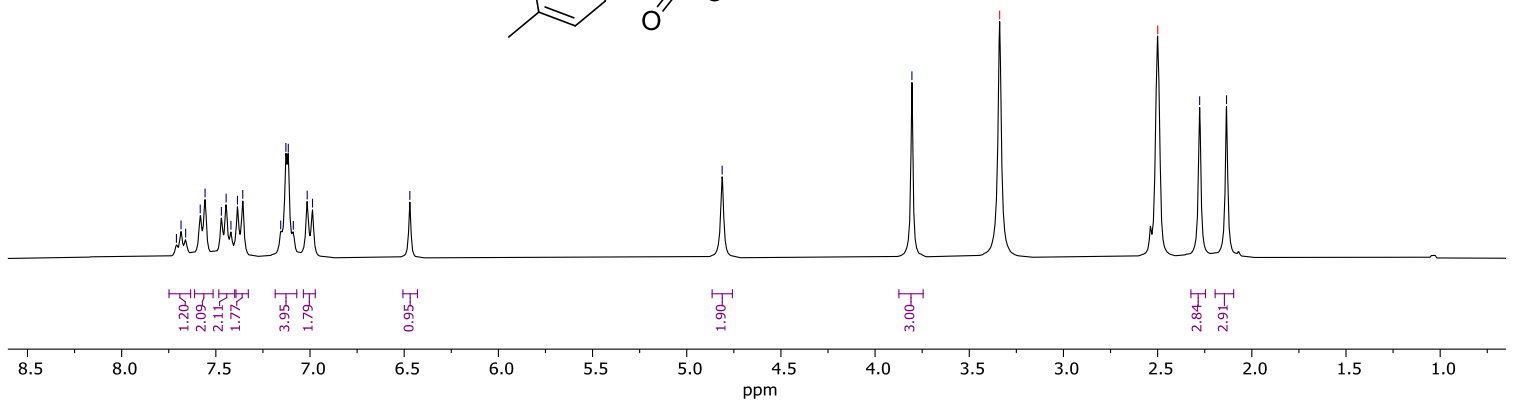

${ }^{13} \mathrm{C}\left\{{ }^{1} \mathrm{H}\right\}$ NMR spectrum (75 MHz) of $18 \mathrm{c}$ in DMSO- $d_{6}$

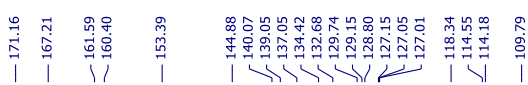<smiles>COc1ccc(-c2oc(=O)n(Cc3ccc(C)cc3)c2-c2oc(C)cc(=O)c2OC(=O)c2ccccc2)cc1</smiles>

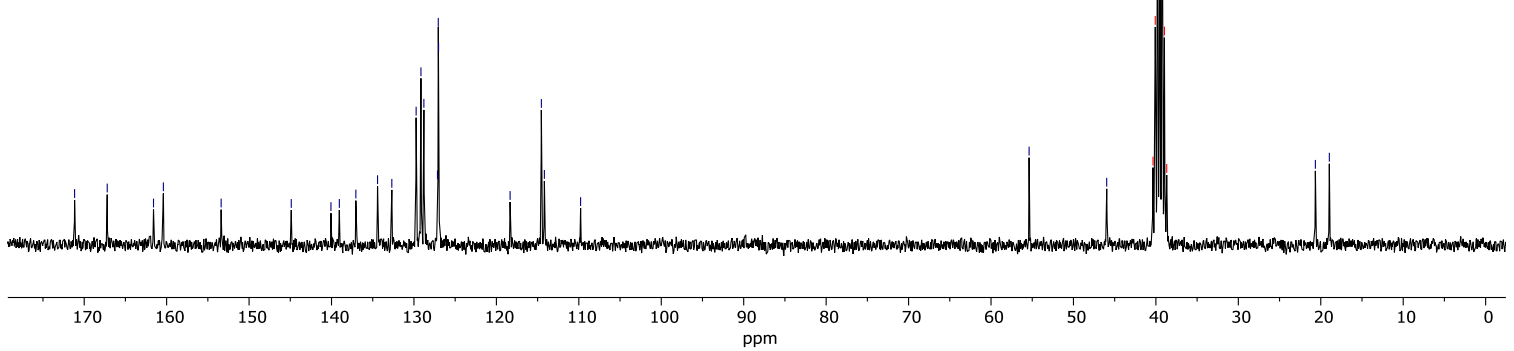


HRMS for compound 18c

Acquisition Parameter

Source Type ESI

Focus Not active

Scan Begin $\quad 50 \mathrm{~m} / \mathrm{z}$

Scan End $\quad 1600 \mathrm{~m} / \mathrm{z}$

Ion Polarity

Positive

Set Nebulizer

$1.0 \mathrm{Bar}$

Set Capillary $4500 \mathrm{~V}$

$200{ }^{\circ} \mathrm{C}$

Set End Plate Offset $\quad-500 \mathrm{~V}$

Set Divert Valve

$4.0 \mathrm{l} / \mathrm{min}$

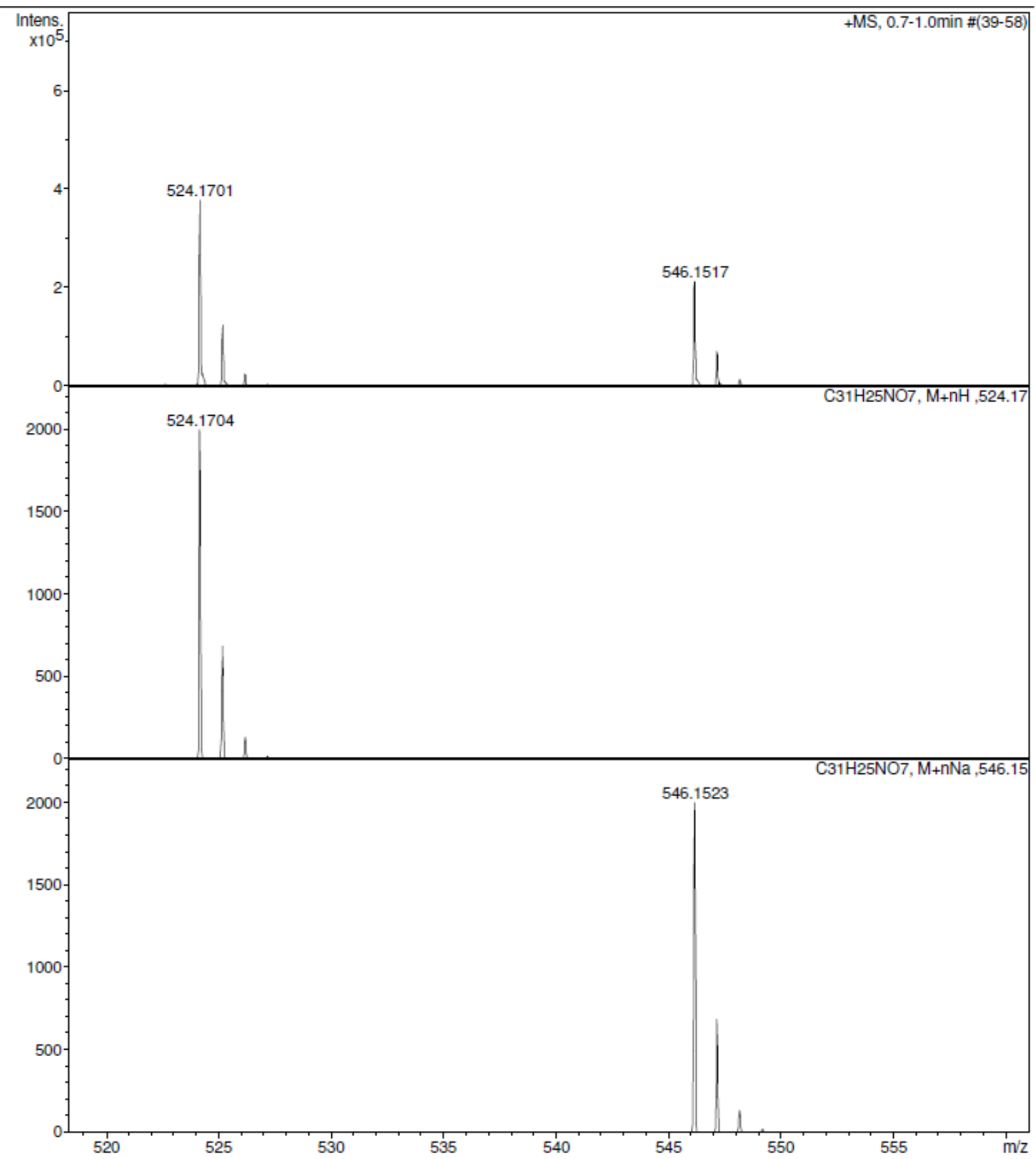

540

545

555 
${ }^{1} \mathrm{H}$ NMR spectrum $\left(300 \mathrm{MHz}\right.$ ) of $\mathbf{1 8 d}$ in DMSO- $d_{6}$

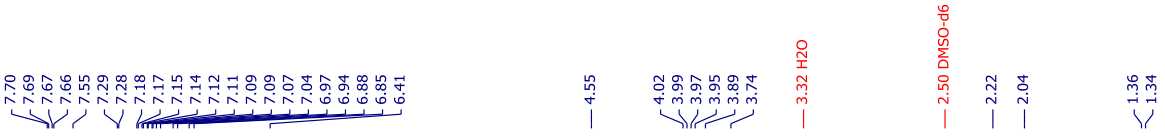

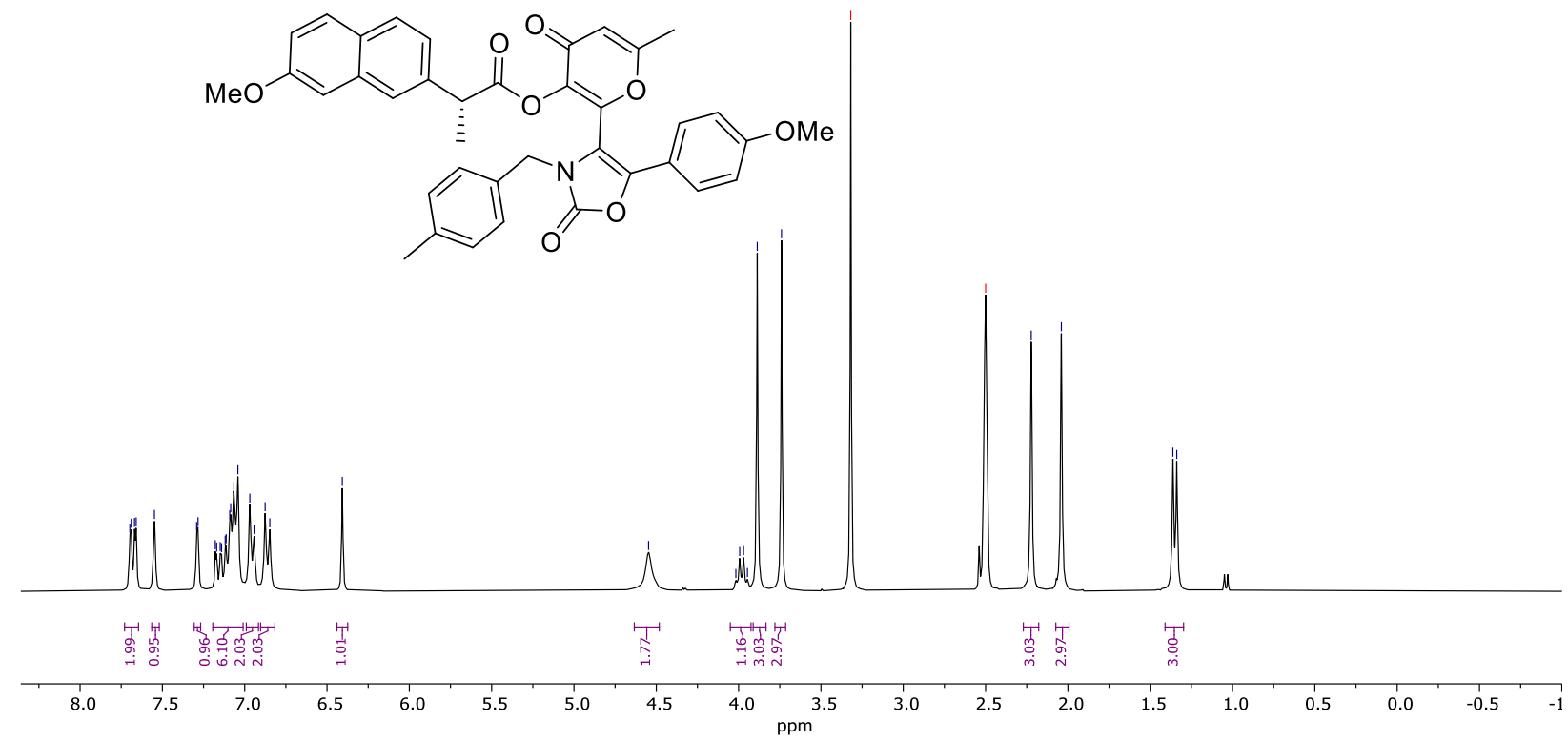

${ }^{13} \mathrm{C}\left\{{ }^{1} \mathrm{H}\right\}$ NMR spectrum (75 MHz) of $\mathbf{1 8 d}$ in DMSO- $d_{6}$

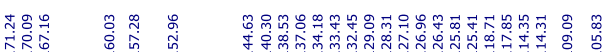

|र । । । ।

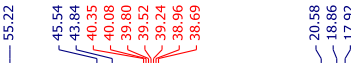
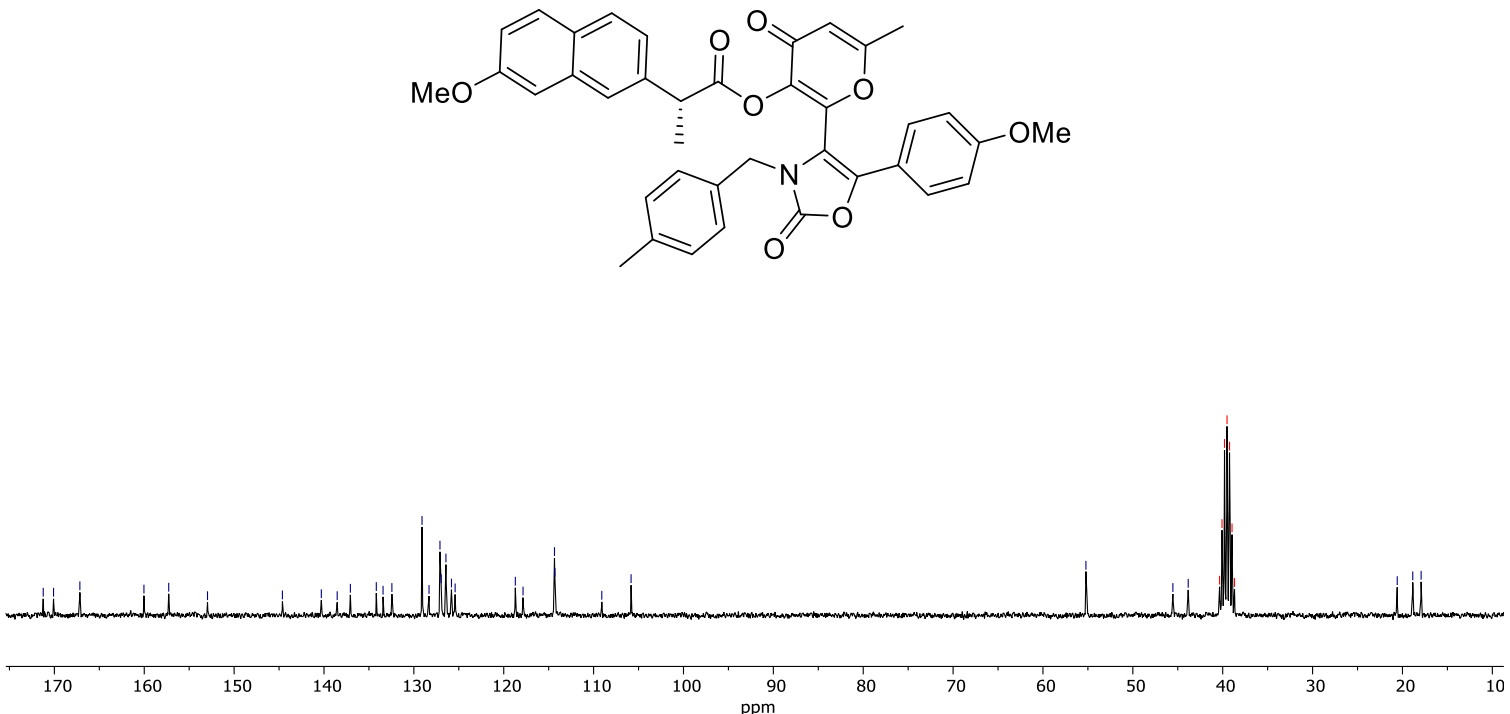
HRMS for compound $\mathbf{1 8 d}$

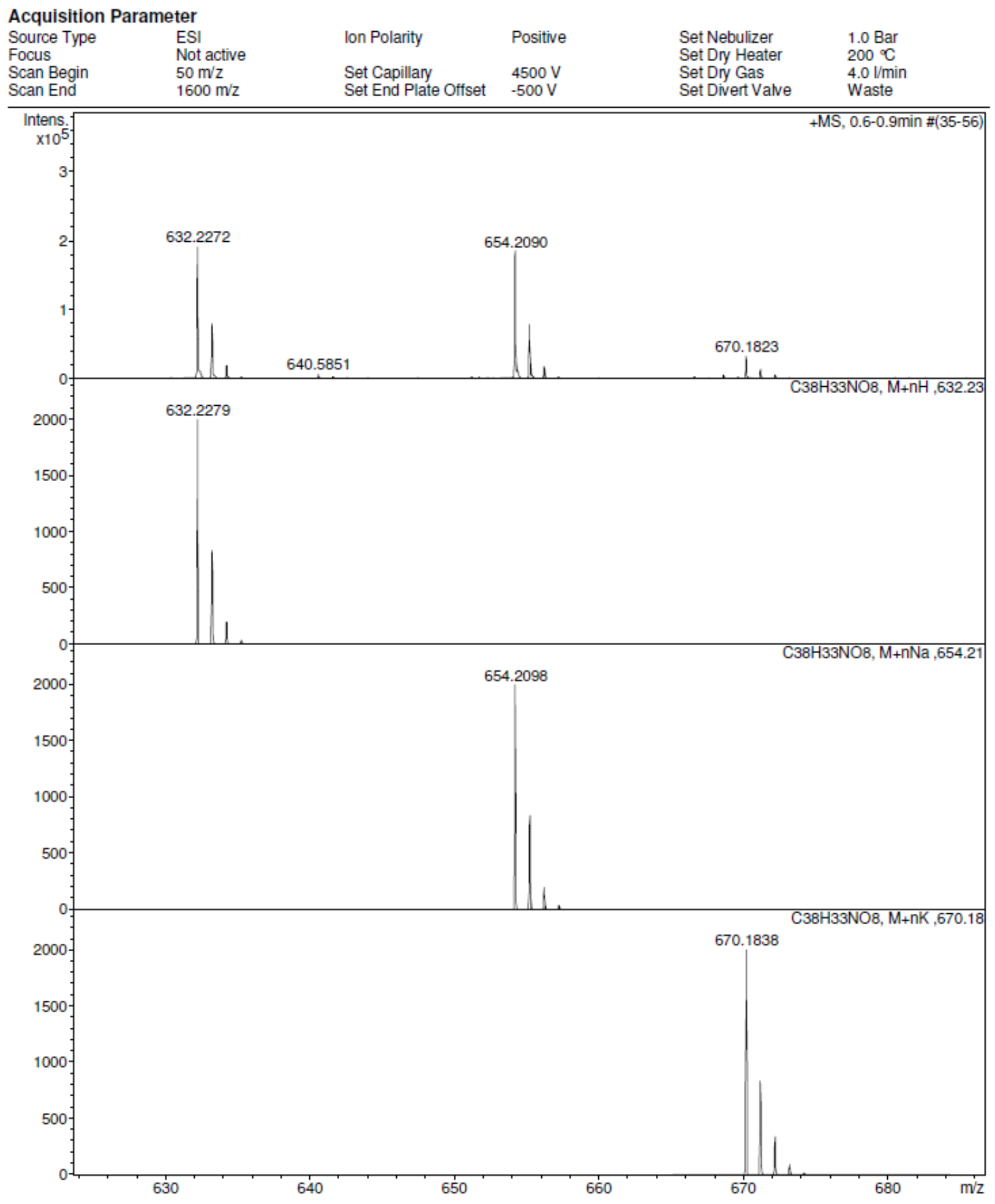


8. Copies of ${ }^{1} \mathrm{H},{ }^{13} \mathrm{C}$ NMR and HRMS for compounds 19 and 20.

${ }^{1} \mathrm{H}$ NMR spectrum (300 MHz) of 19 in DMSO- $d_{6}$

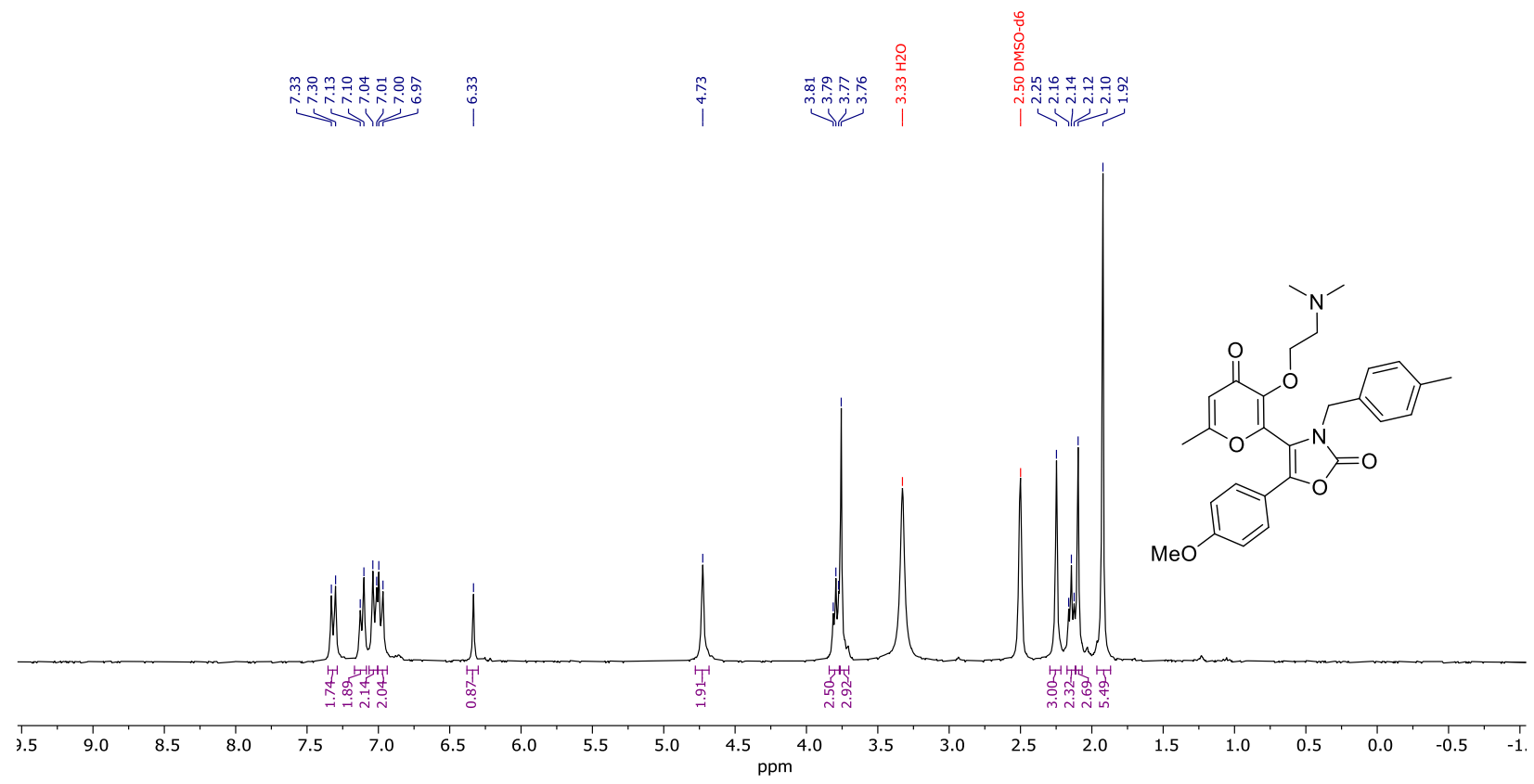

${ }^{13} \mathrm{C}\left\{{ }^{1} \mathrm{H}\right\}$ NMR spectrum (126 MHz) of 19 in DMSO- $d_{6}$

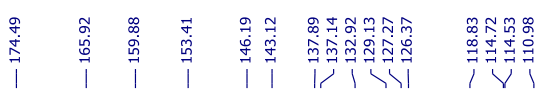
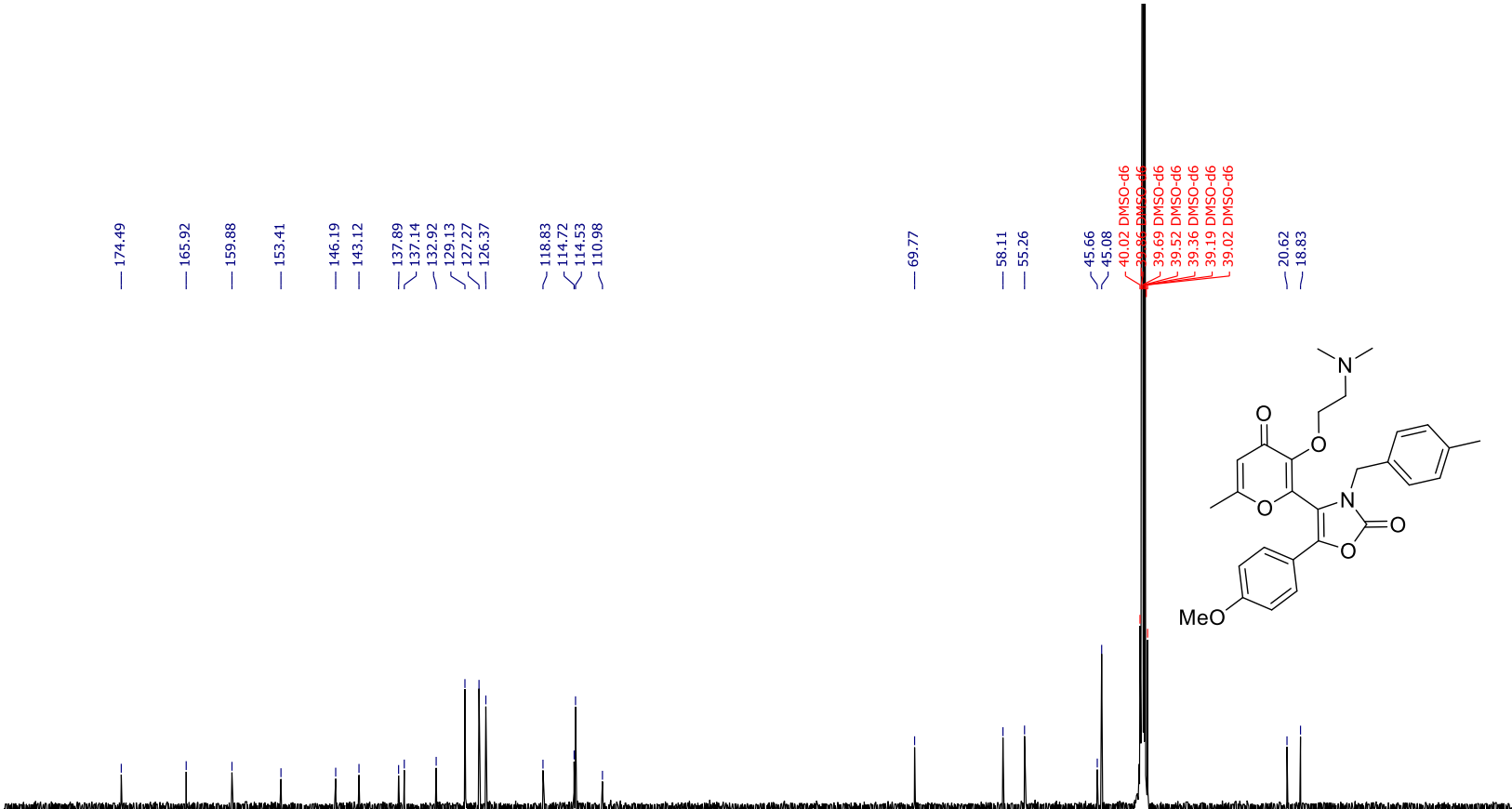

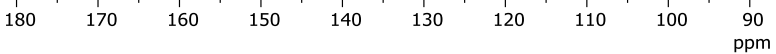


HRMS for compound 19

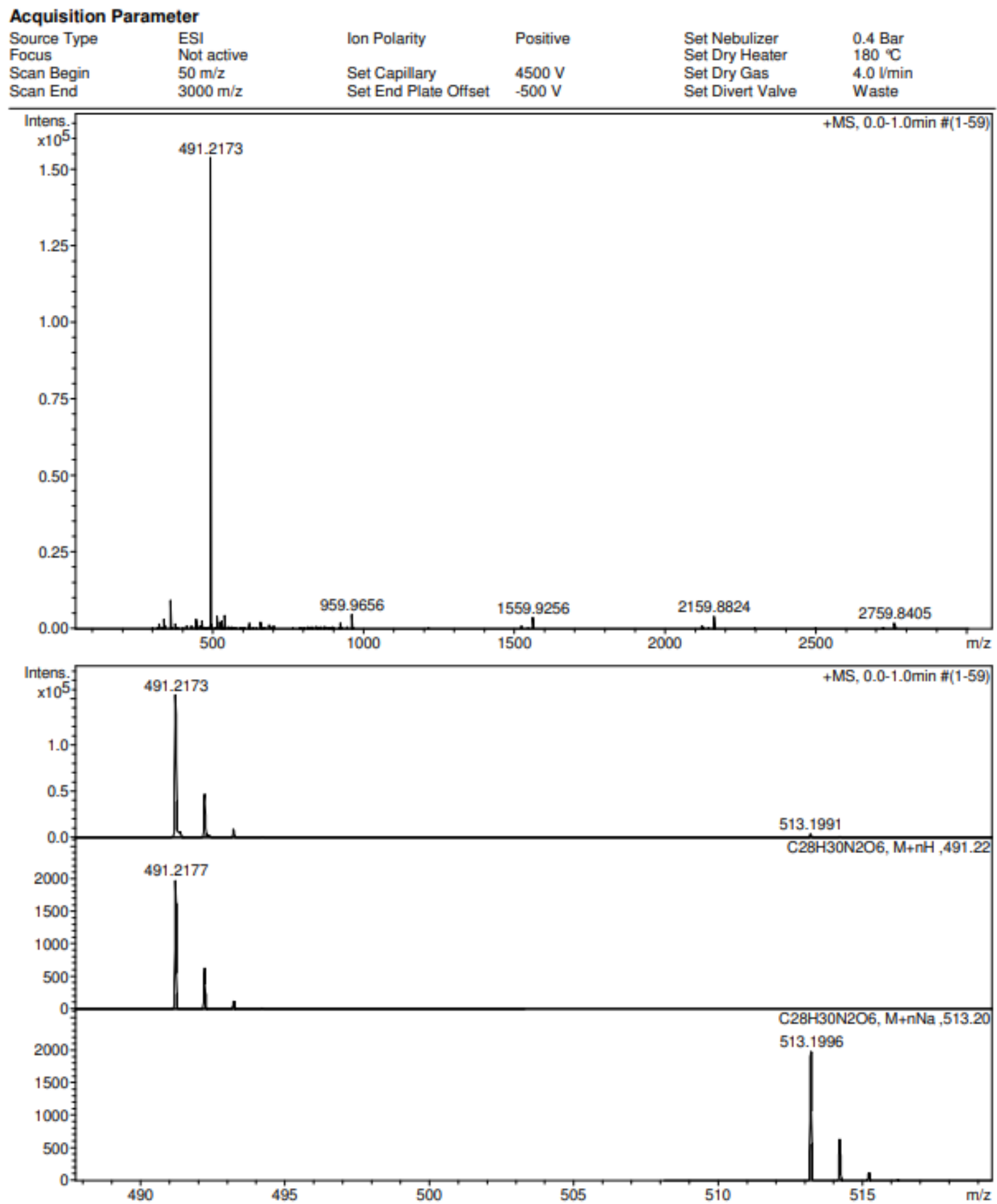


${ }^{1} \mathrm{H}$ NMR spectrum $(500 \mathrm{MHz})$ of 20 in DMSO- $d_{6}$

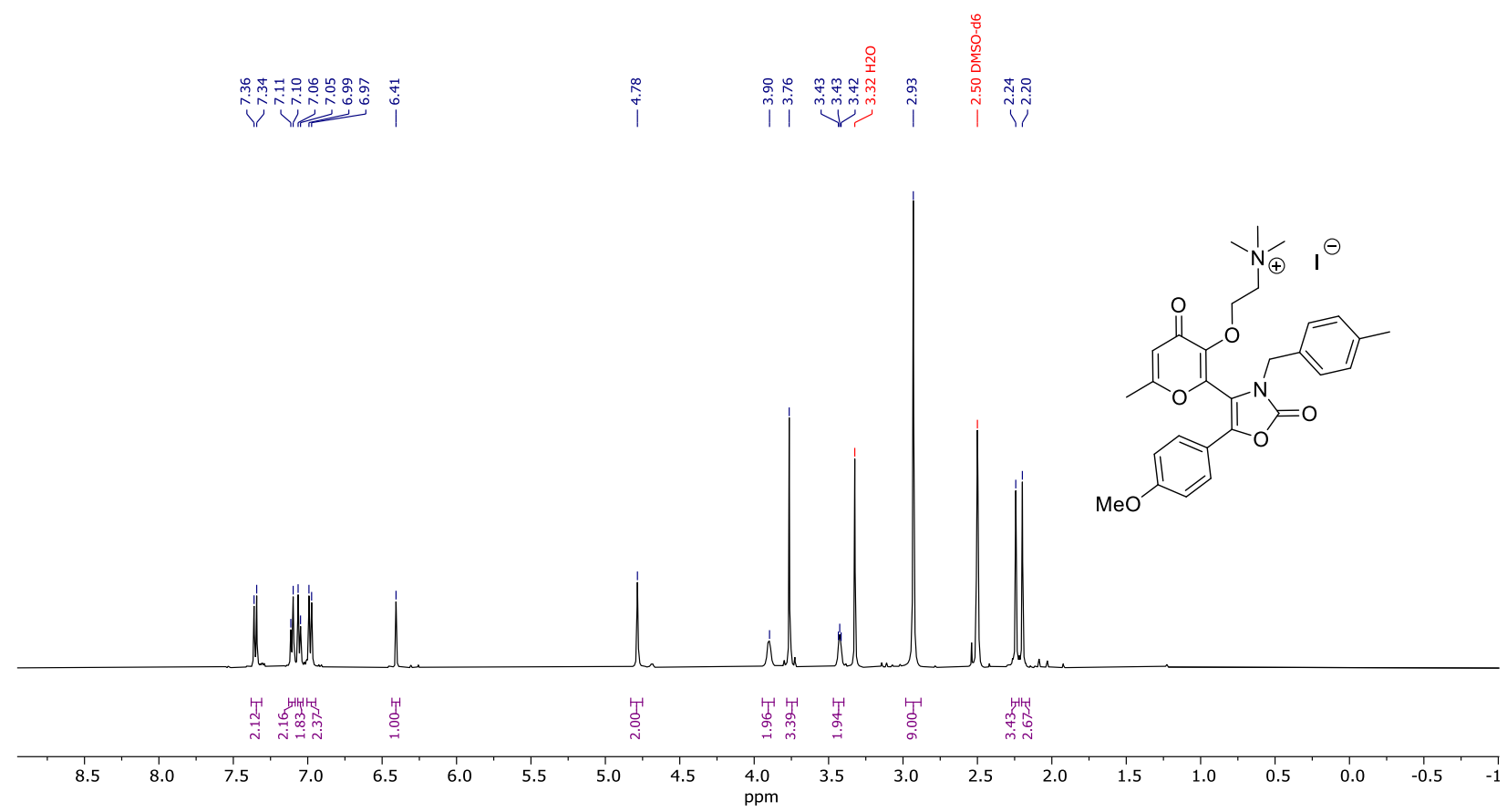

${ }^{13} \mathrm{C}\left\{{ }^{1} \mathrm{H}\right\}$ NMR spectrum (126 MHz) of 20 in DMSO- $d_{6}$

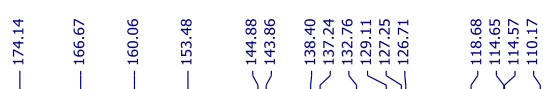

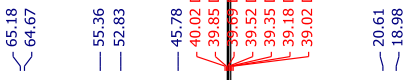

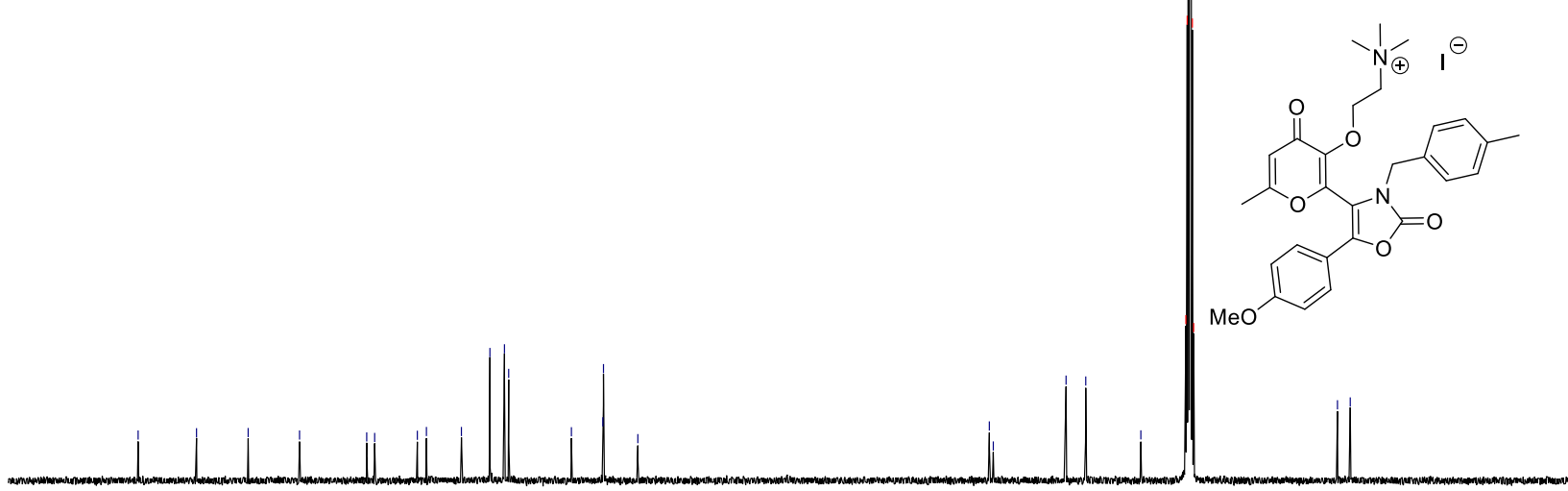

90

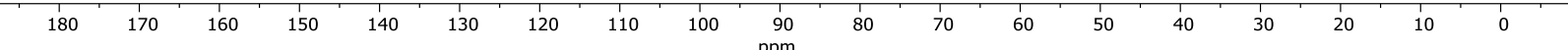


HRMS for compound $\mathbf{2 0}$

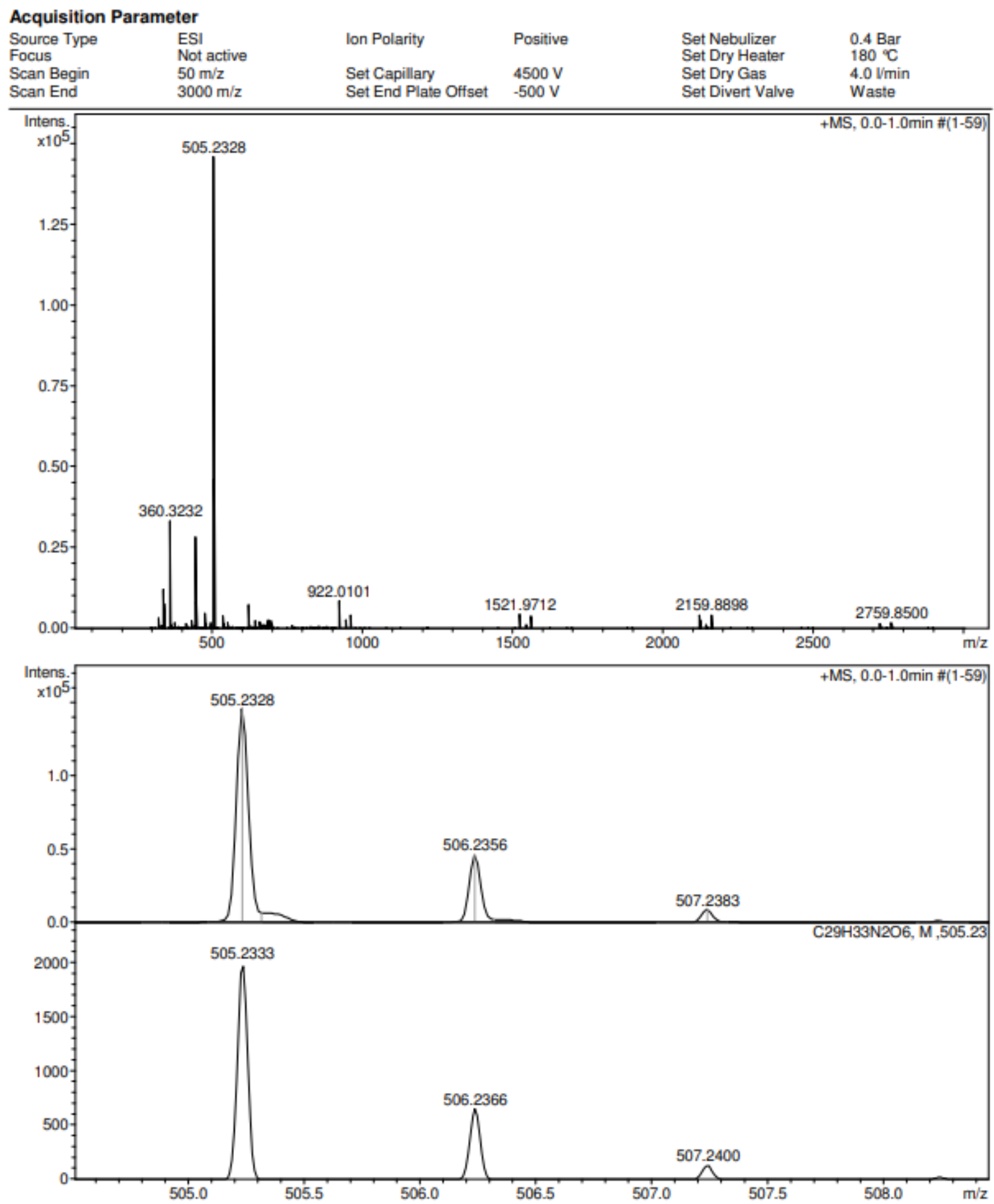


9. Copies of ${ }^{1} \mathrm{H},{ }^{13} \mathrm{C}$ NMR and HRMS for compounds 21-23.

${ }^{1} \mathrm{H}$ NMR spectrum $\left(300 \mathrm{MHz}\right.$ ) of 21 in DMSO- $d_{6}$

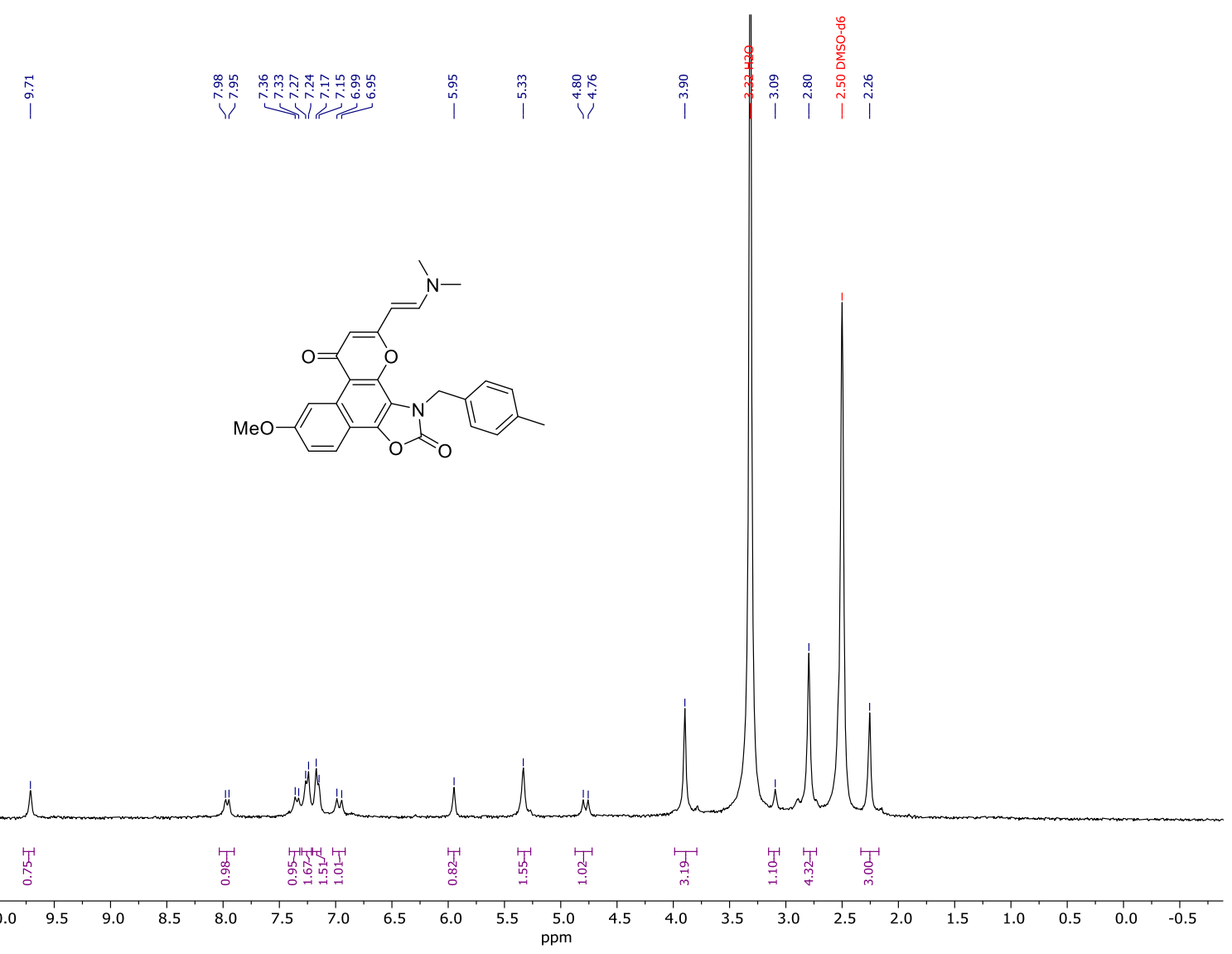

${ }^{13} \mathrm{C}\left\{{ }^{1} \mathrm{H}\right\}$ NMR spectrum $(75 \mathrm{MHz})$ of 21 in DMSO- $d_{6}$

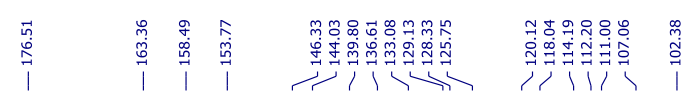

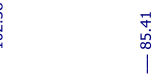
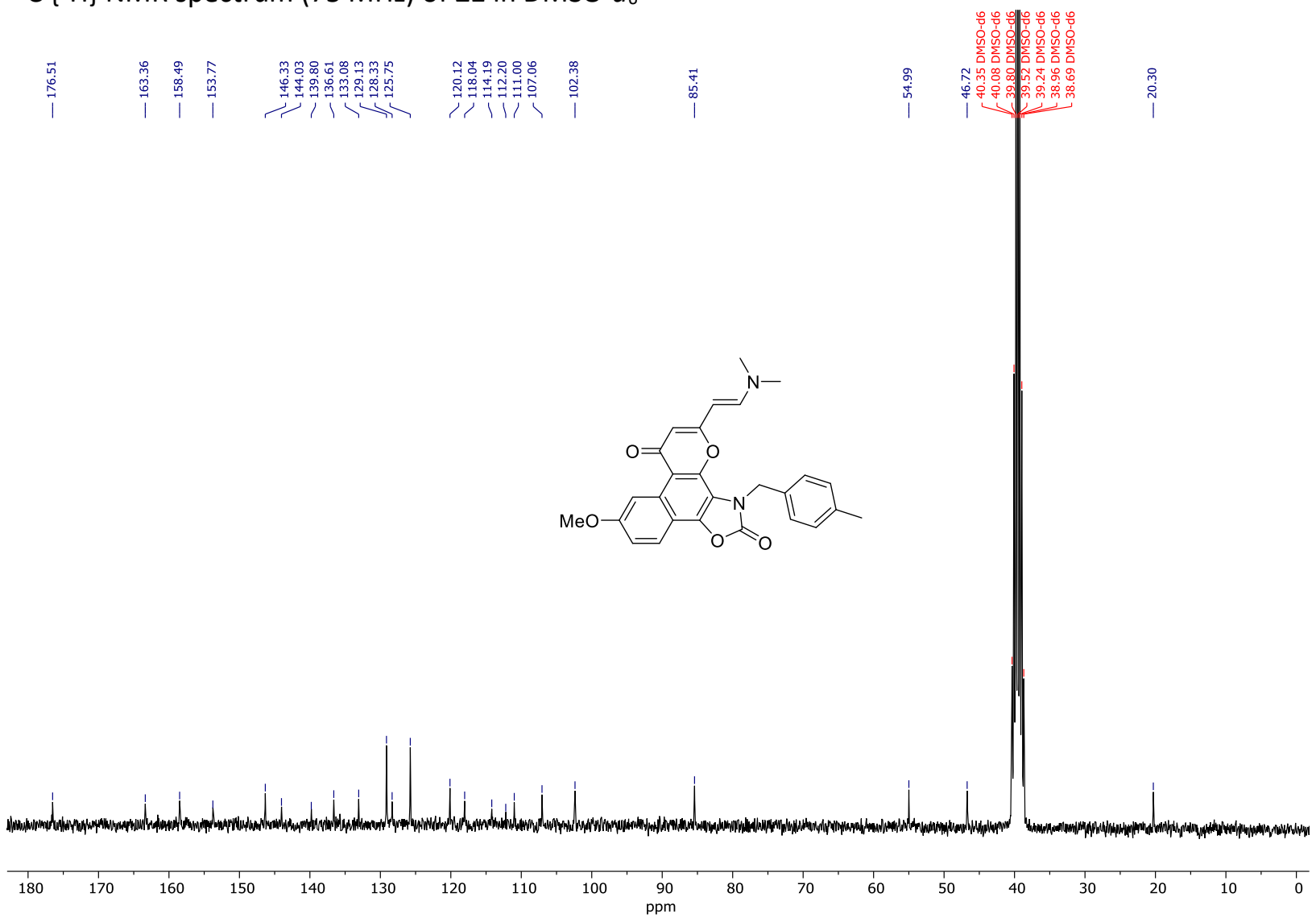
HRMS for compound $\mathbf{2 1}$

\section{Acquisition Parameter}

\section{Source Type ESI}

Focus

Not active

Scan Begin $\quad 50 \mathrm{~m} / \mathrm{z}$

Ion Polarity

Positive

Set Nebulizer

Set Dry Heater

1.0 Bar

Set Capillary $\quad 4500$ V

Set Dry Gas

Scan End $\quad 1600 \mathrm{~m} / \mathrm{z}$

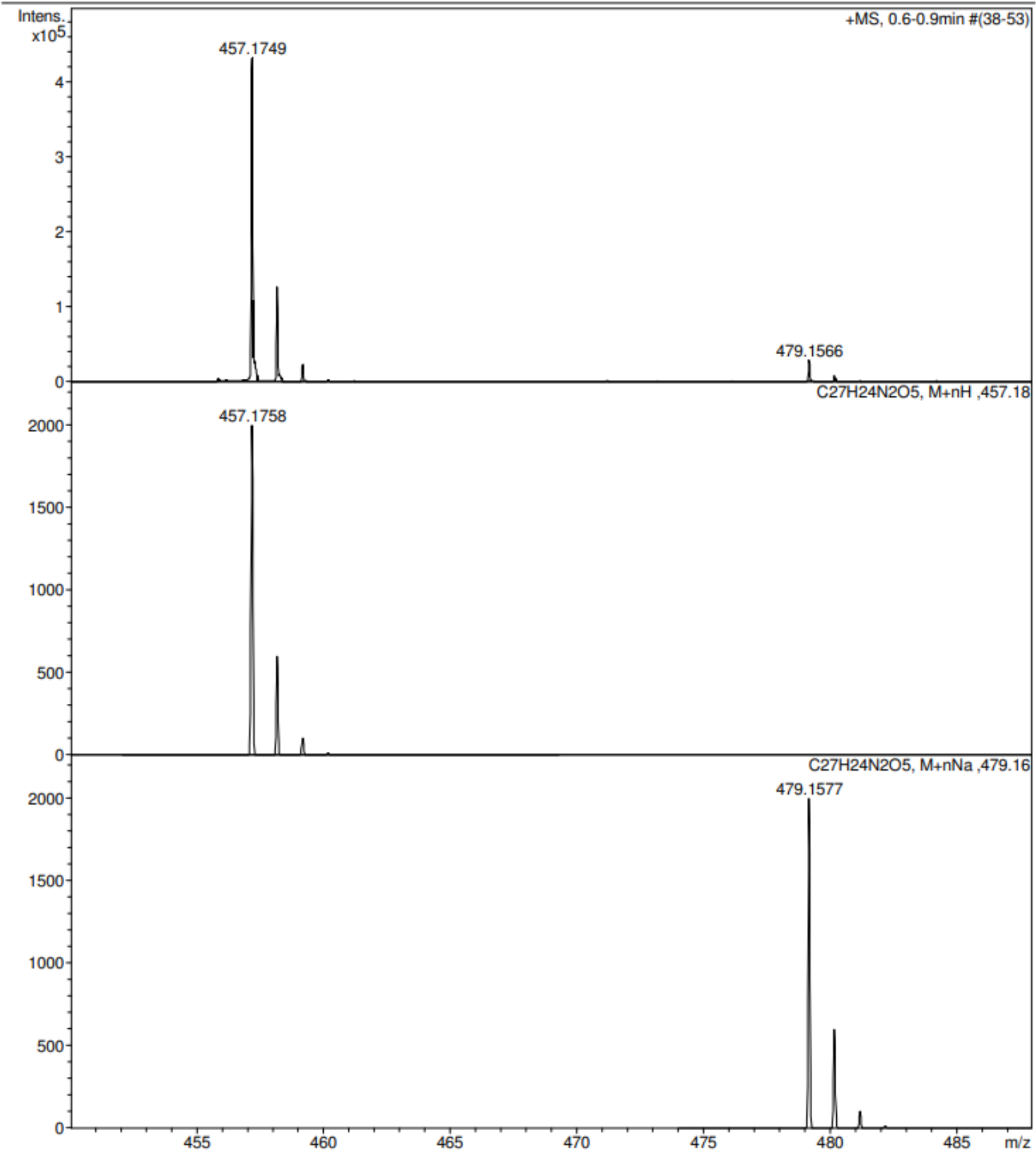


${ }^{1} \mathrm{H}$ NMR spectrum (300 MHz) of 22 in DMSO- $d_{6}$

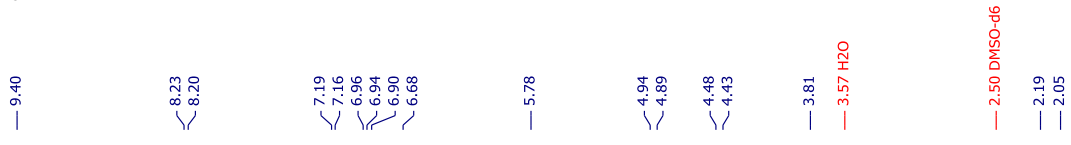<smiles>COc1ccc2c(O)c(N(Cc3ccc(C)cc3)C(=O)NN)c3oc(C)cc(=O)c3c2c1</smiles>

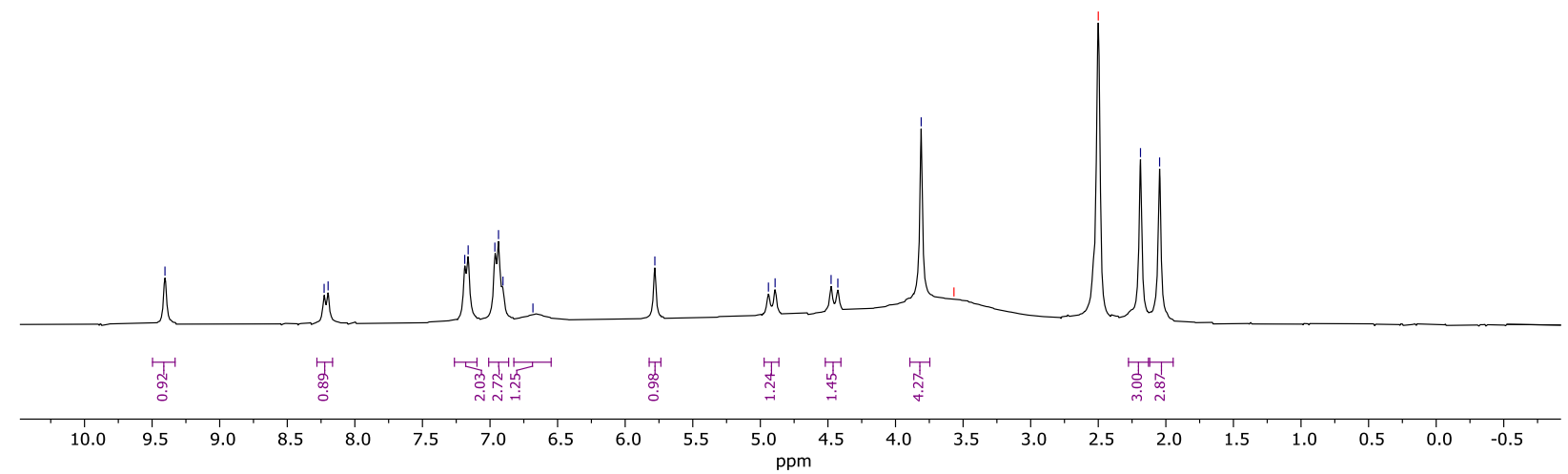

${ }^{13} \mathrm{C}\left\{{ }^{1} \mathrm{H}\right\}$ NMR spectrum (75 MHz) of 22 in DMSO- $d_{6}$

\begin{tabular}{|c|c|}
\hline 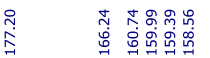 & 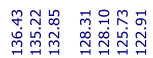 \\
\hline
\end{tabular}

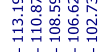

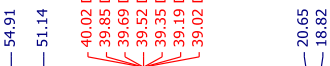

|

1/ Vरा ए111
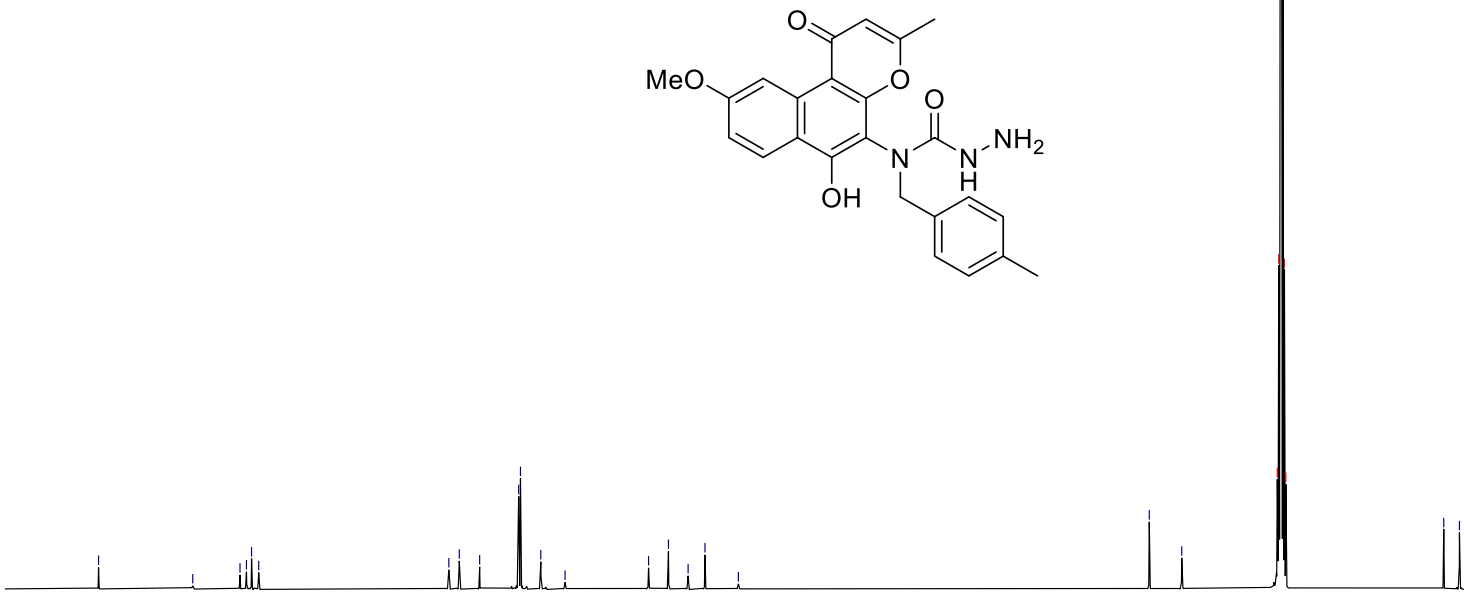
HRMS for compound 22

\section{Acquisition Parameter}

\section{Source Type ESI}

Focus Not active

Scan Begin $\quad 50 \mathrm{~m} / \mathrm{z}$

Scan End $\quad 1600 \mathrm{~m} / \mathrm{z}$

Ion Polarity

Set Capillary

Set End Plate Offset
Positive

$4500 \mathrm{~V}$

$-500 \mathrm{~V}$
Set Nebulizer

Set Dry Heater

Set Dry Gas

Set Divert Valve
1.0 Bar

$200^{\circ} \mathrm{C}$

$4.0 \mathrm{l} / \mathrm{min}$ Waste

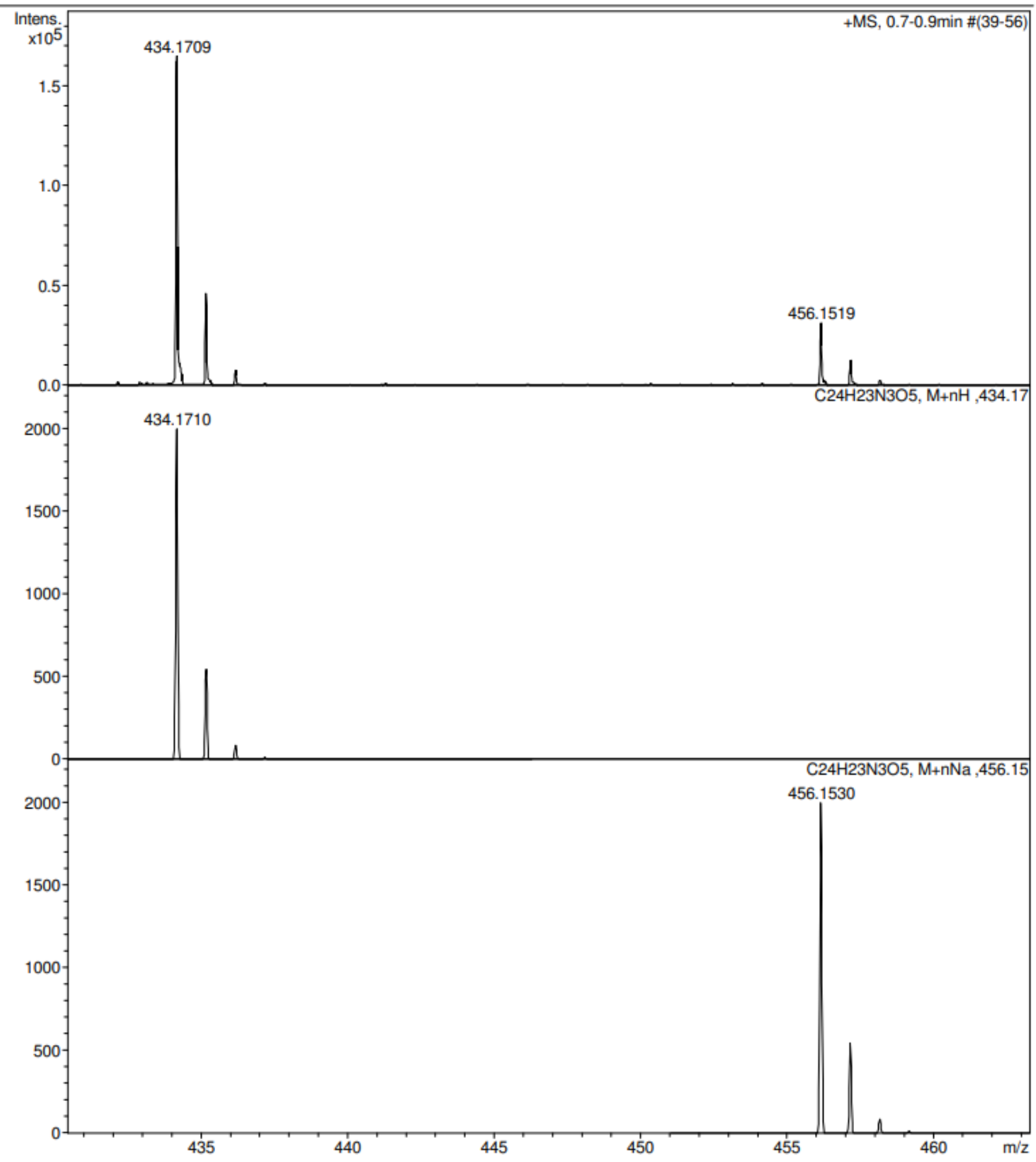


${ }^{1} \mathrm{H}$ NMR spectrum (300 MHz) of 23 in DMSO- $d_{6}$

产

$\underset{\substack{\square \\ \infty}}{\substack{\infty \\ \infty}}$

i

₹

กำ
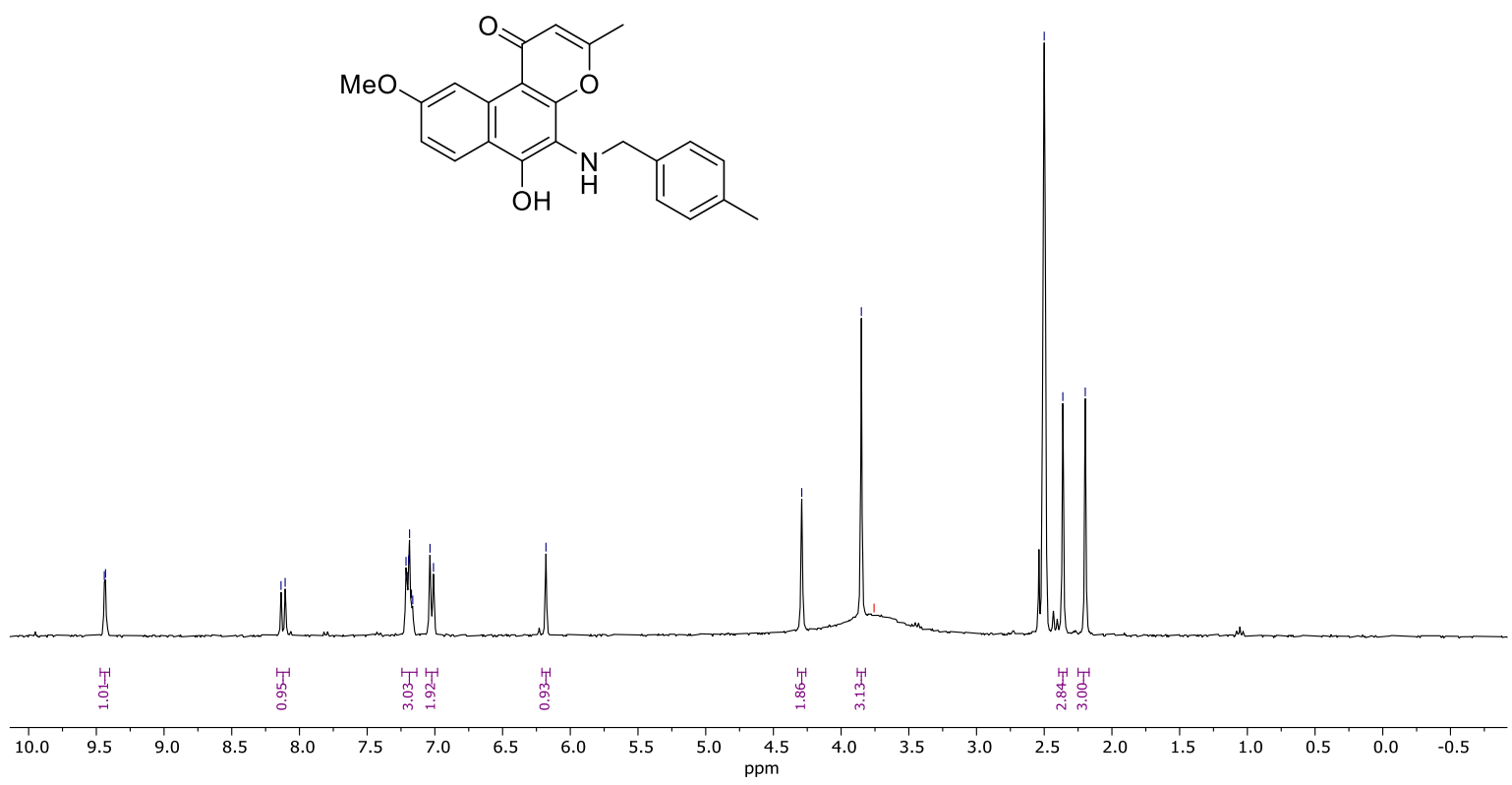

${ }^{13} \mathrm{C}\left\{{ }^{1} \mathrm{H}\right\}$ NMR spectrum $\left(75 \mathrm{MHz}\right.$ ) of 23 in DMSO- $d_{6}$

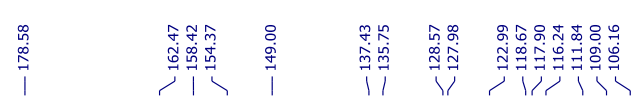

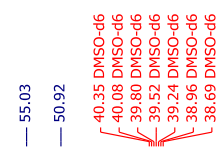

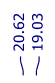
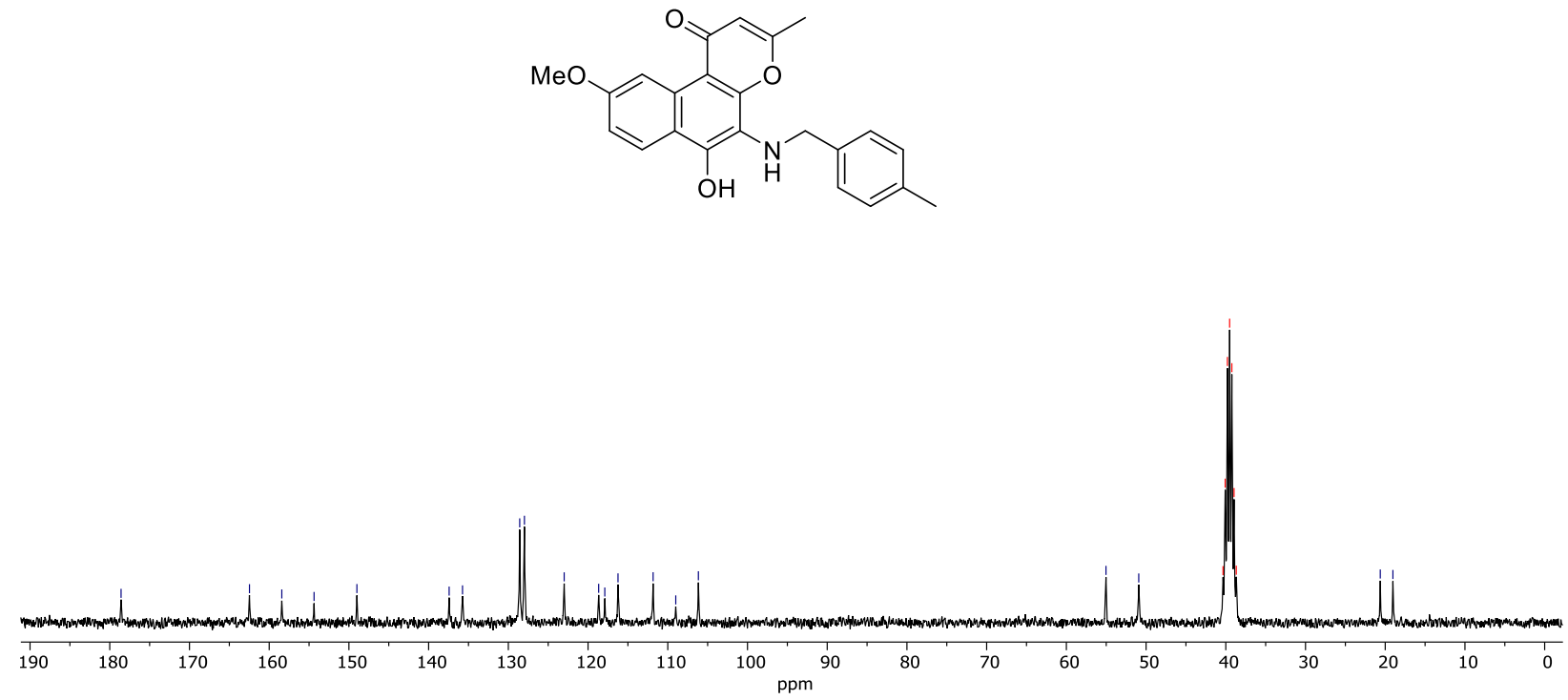

S101 
HRMS for compound $\mathbf{2 3}$

Acquisition Parameter

Source Type ESI

Focus

Scan Begin

Not active

Scan End

$50 \mathrm{~m} / \mathrm{z}$

Positive

Set Nebulizer

Set Dry Heater

Set Dry Gas

Set Capillary

$4500 \mathrm{~V}$

Set Divert Valve

Set End Plate Offset $\quad-500 \mathrm{~V}$

Waste

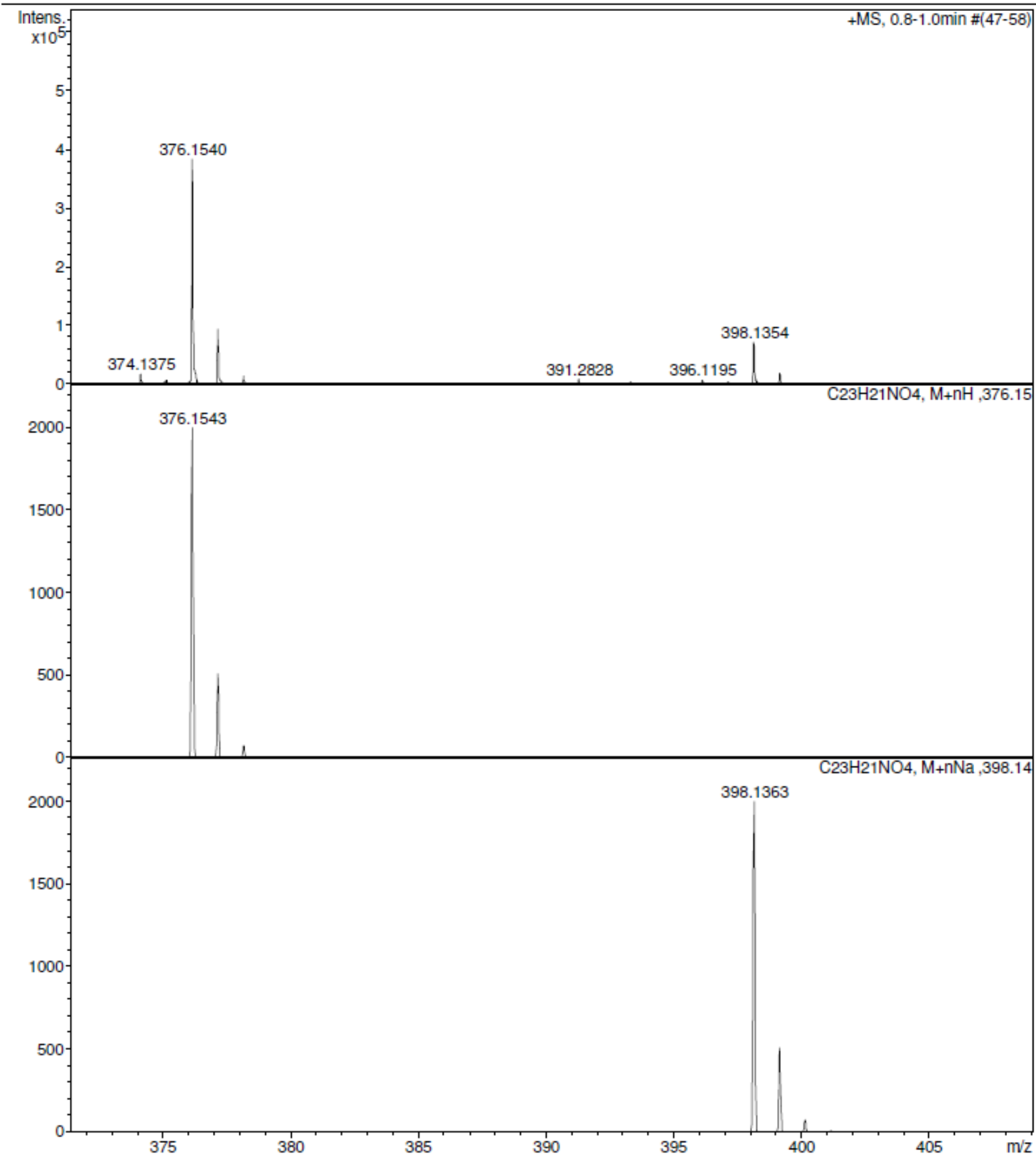


10. ${ }^{1} \mathrm{H}$ NMR monitoring of the photoreactions.

Scheme S1. Synthesis of Methylated Terarylene 14a and Photoproduct 15a.
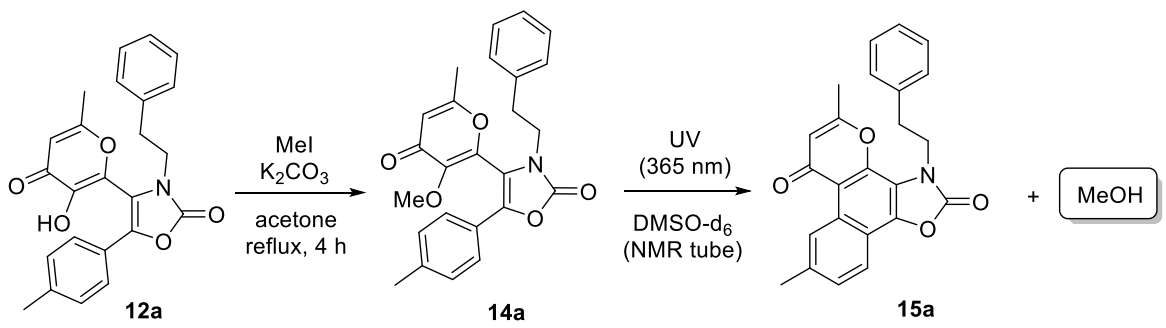

C) After 8h UV-irradiation

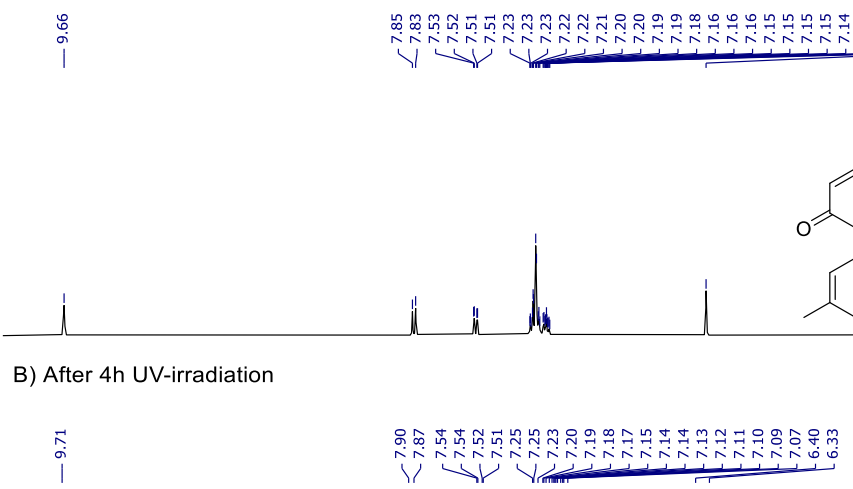

$14 a+15 a+M e O H$

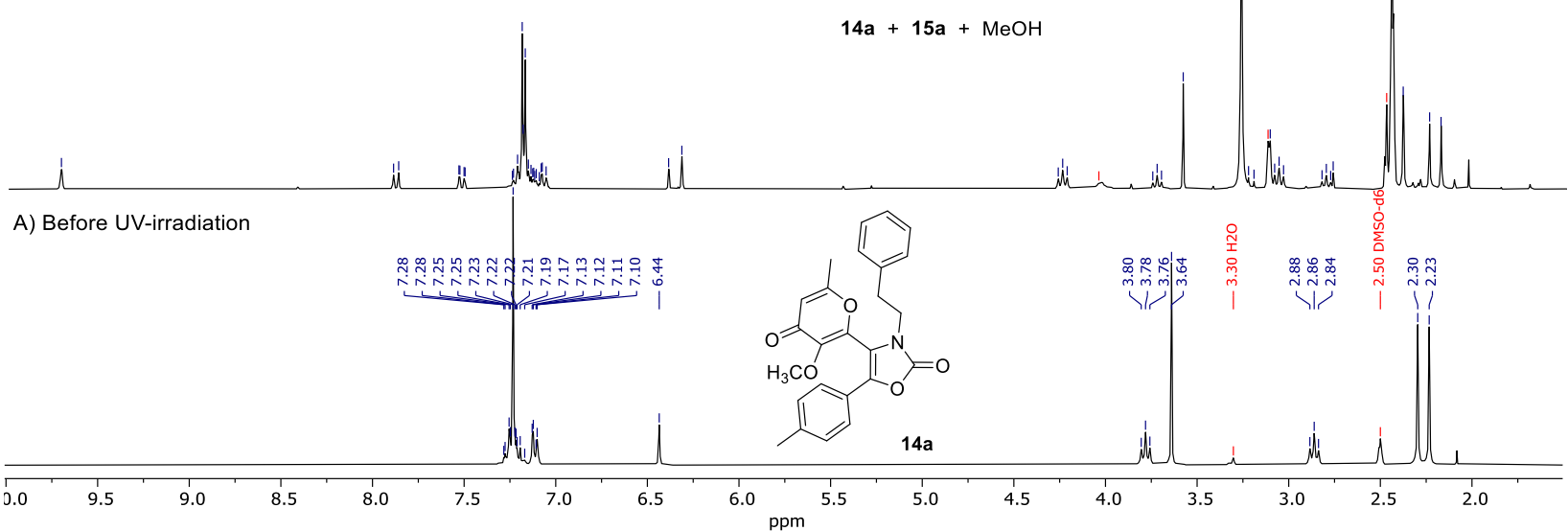

Fig. S1. ${ }^{1} \mathrm{H}$ NMR monitoring of the photoreaction of compound 14a under UV-irradiation $(365 \mathrm{~nm})$ in DMSO- $d_{6}$ solution. 
Scheme S2. Synthesis of tosylated Terarylene 18a and Photoproduct 15a.

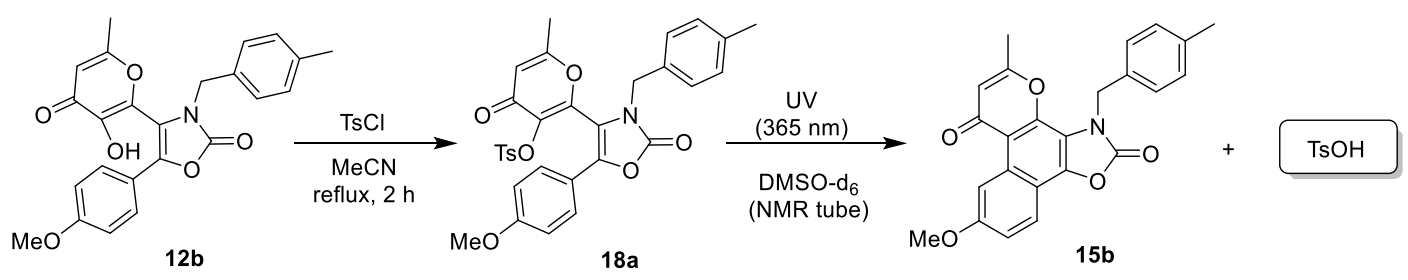

C) Compound 15b

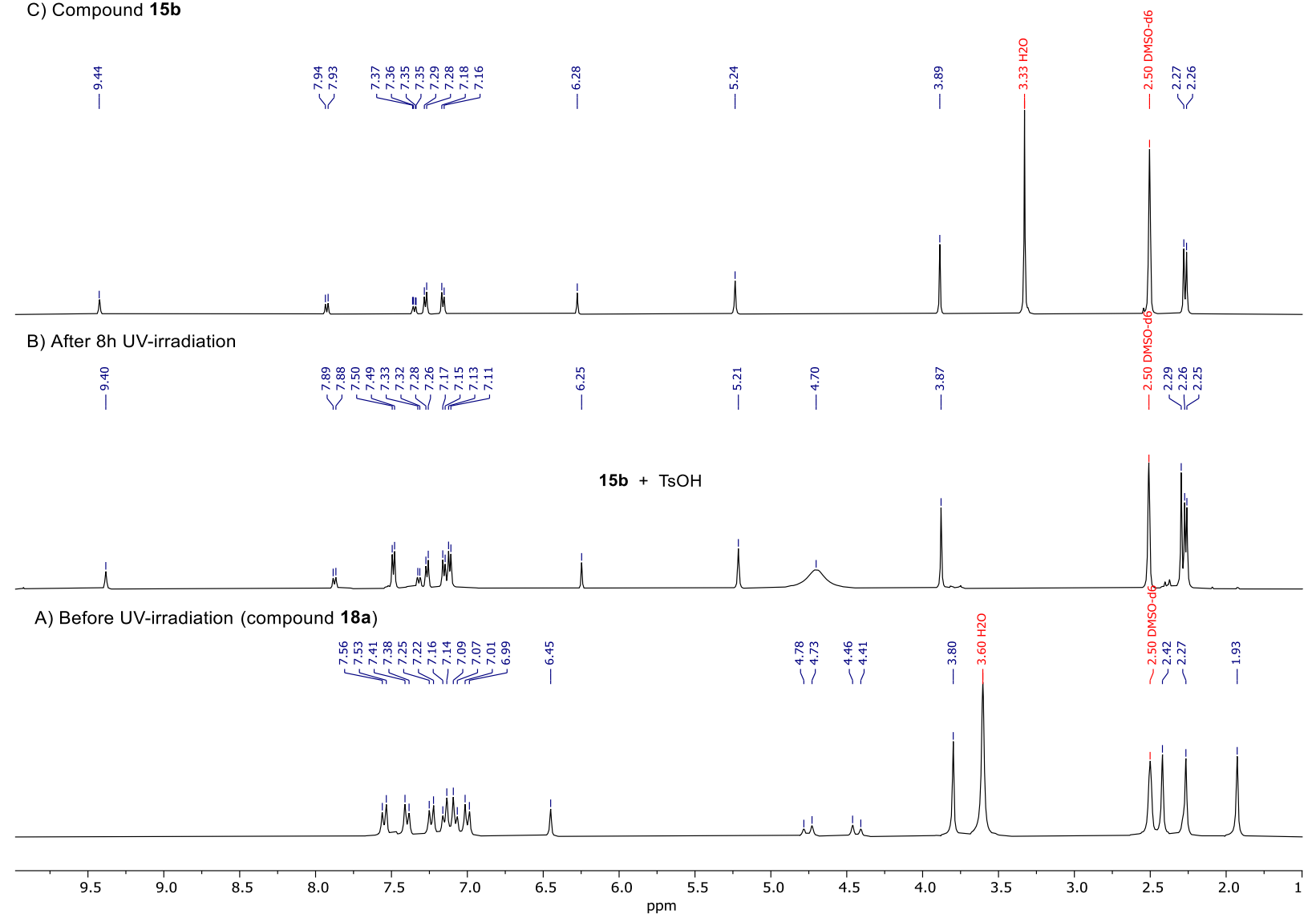

Fig. S2. ${ }^{1} \mathrm{H}$ NMR monitoring of the photoreaction of compound 18a under UV-irradiation $(365 \mathrm{~nm})$ in DMSO- $d_{6}$ solution. 
Scheme S3. Synthesis of Terarylene $\mathbf{1 8 b}$ and Photoproduct 15a.

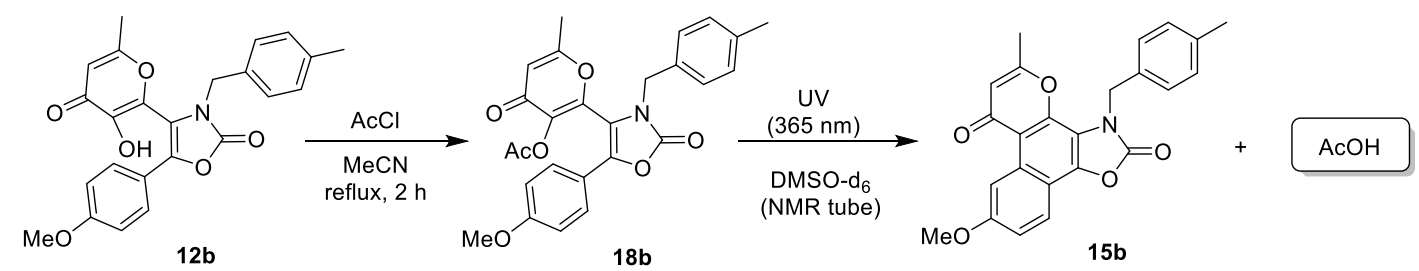

C) Compound 15b

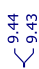

事

i

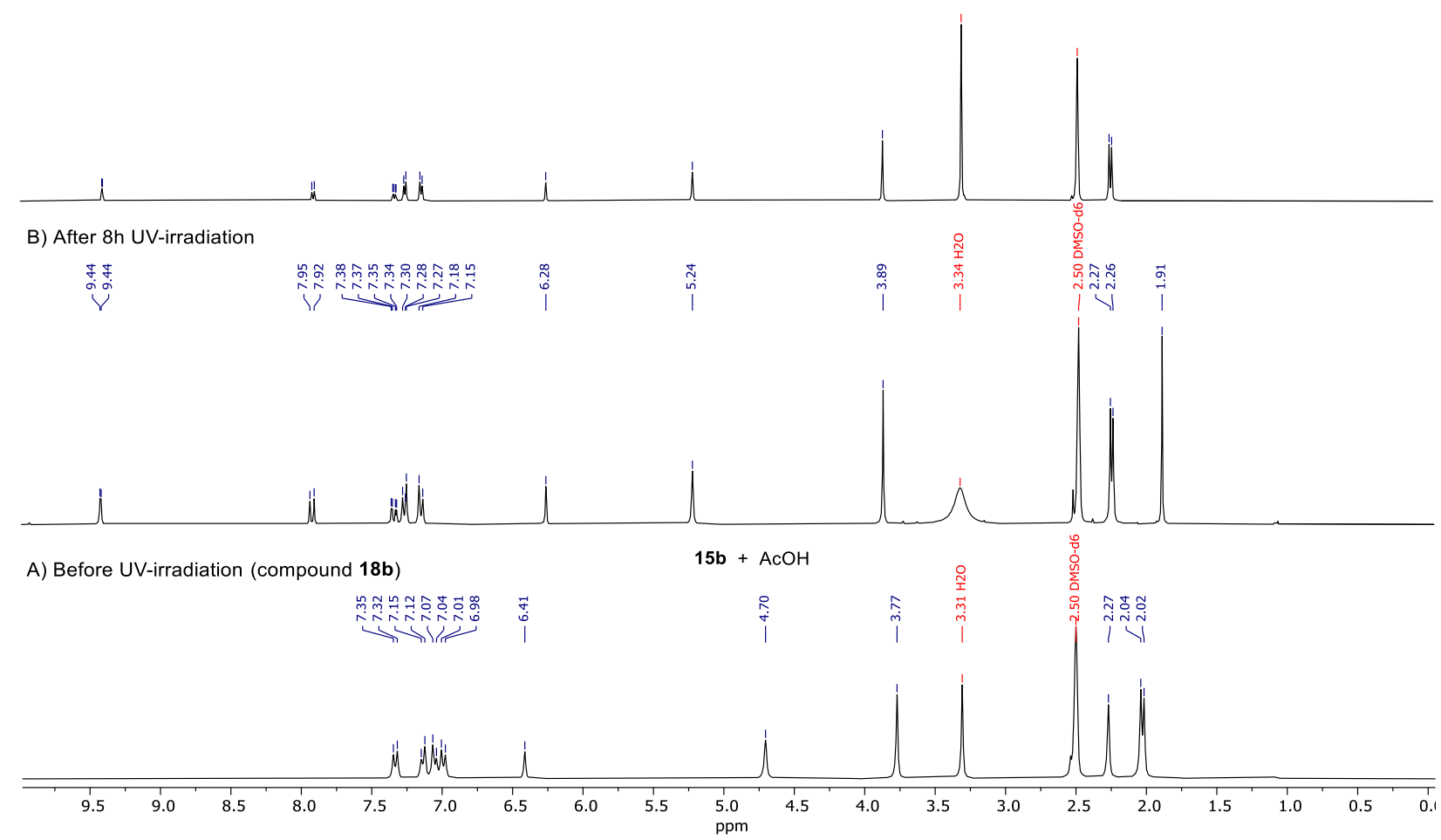

Fig. S3. ${ }^{1} \mathrm{H}$ NMR monitoring of the photoreaction of compound 18b under UV-irradiation $(365 \mathrm{~nm})$ in DMSO- $d_{6}$ solution. 
Scheme S4. Synthesis of Terarylene 18c and Photoproduct 15a.
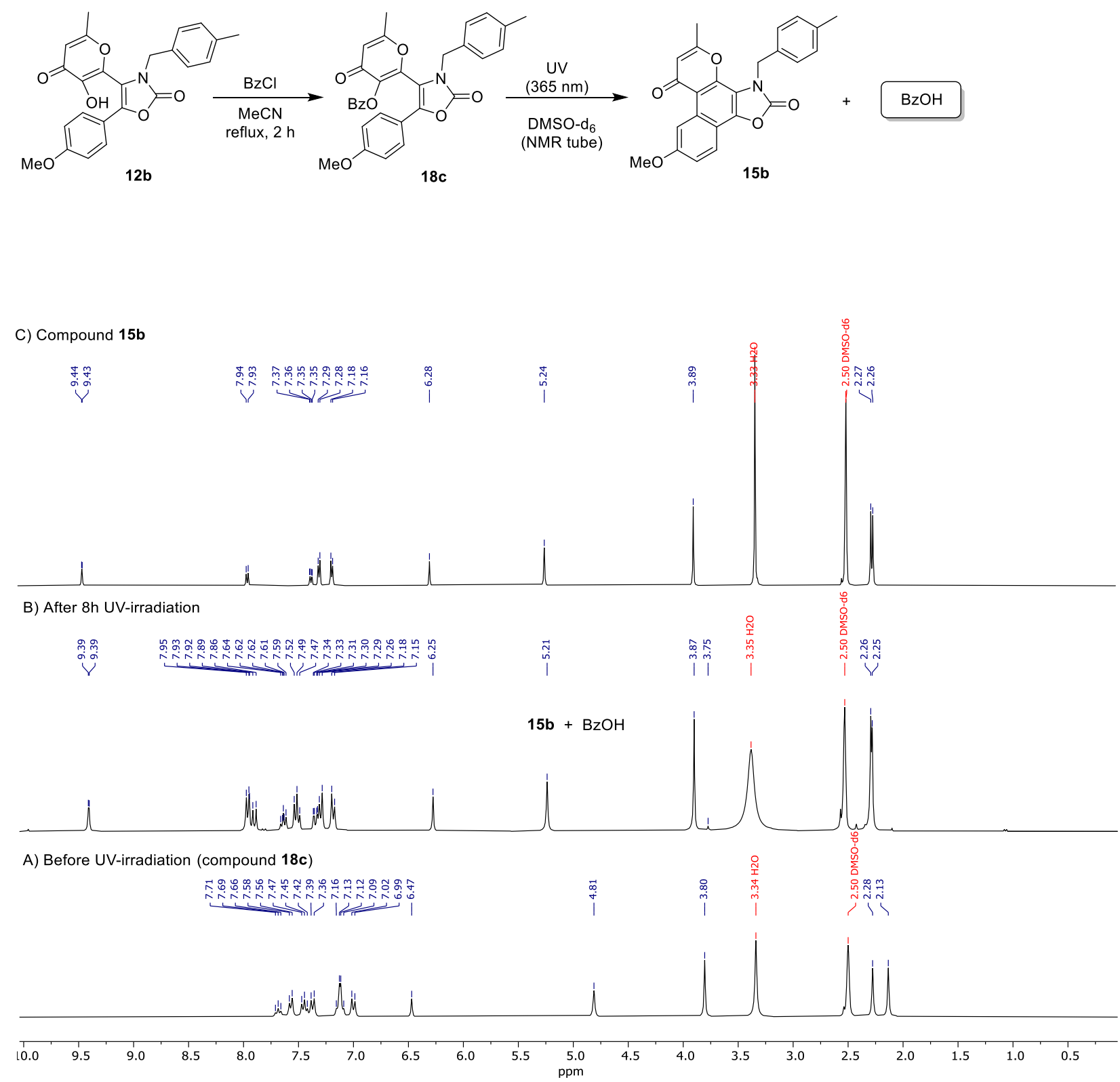

Fig. S4. ${ }^{1} \mathrm{H}$ NMR monitoring of the photoreaction of compound $18 \mathrm{c}$ under UV-irradiation $(365 \mathrm{~nm})$ in DMSO- $d_{6}$ solution. 
Scheme S5. Synthesis of Terarylene 18d and Photoproduct 15a.

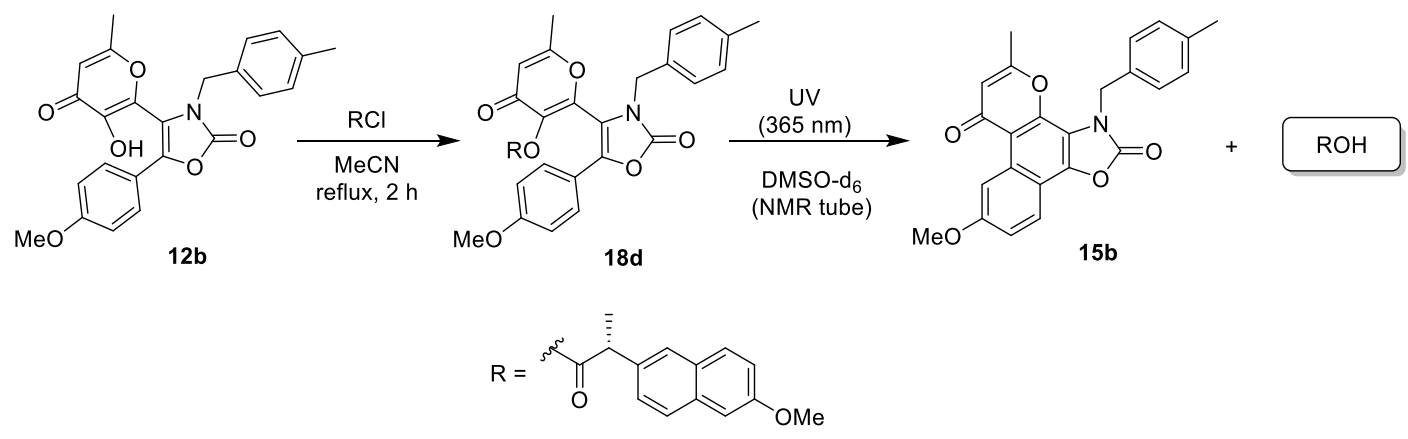

C) Compound 15b

V̛⿱
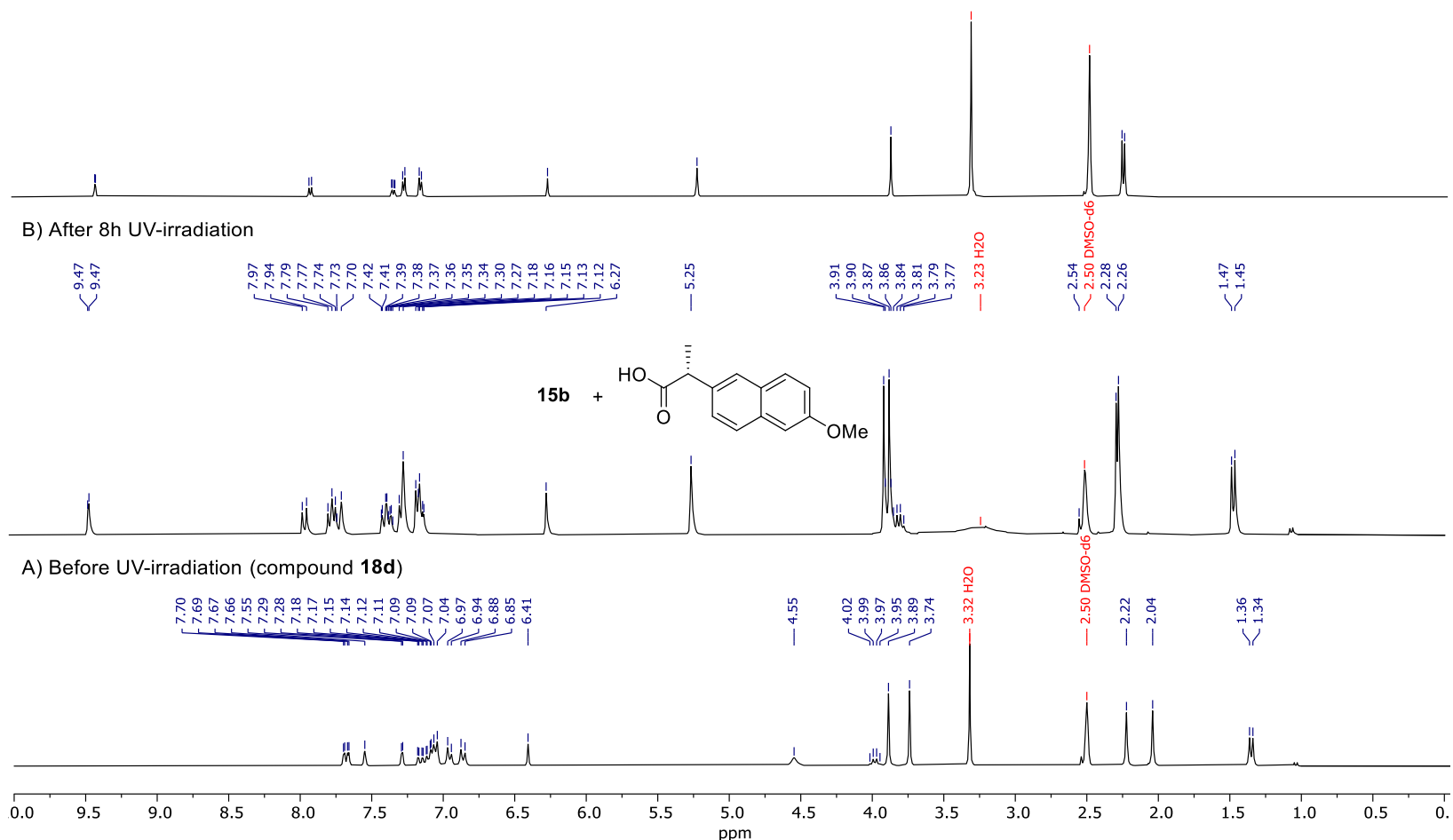

Fig. S5. ${ }^{1} \mathrm{H}$ NMR monitoring of the photoreaction of compound $\mathbf{1 8 d}$ under UV-irradiation $(365 \mathrm{~nm})$ in DMSO- $d_{6}$ solution. 
Scheme S6. Photogeneration of Choline lodide from Compound 20

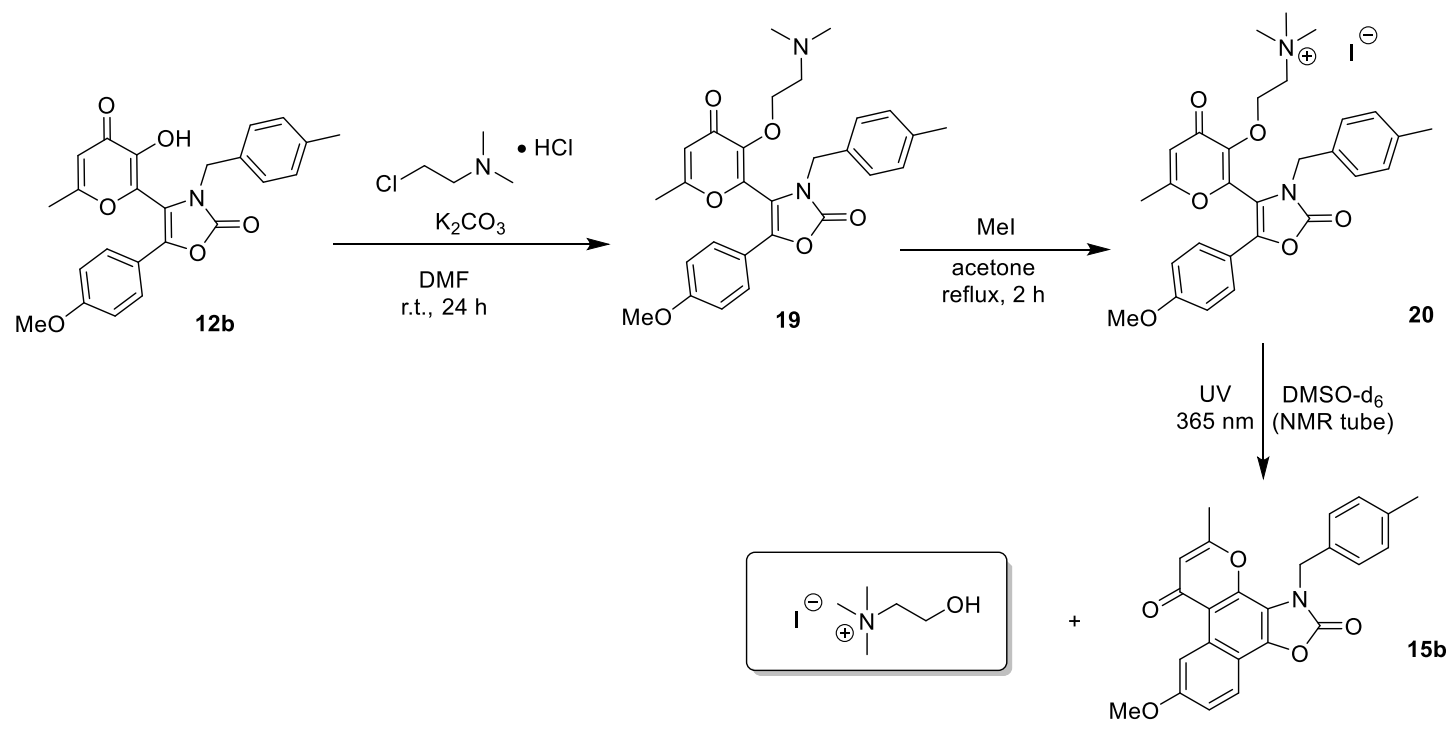

C) Compound $15 \mathrm{~b}$

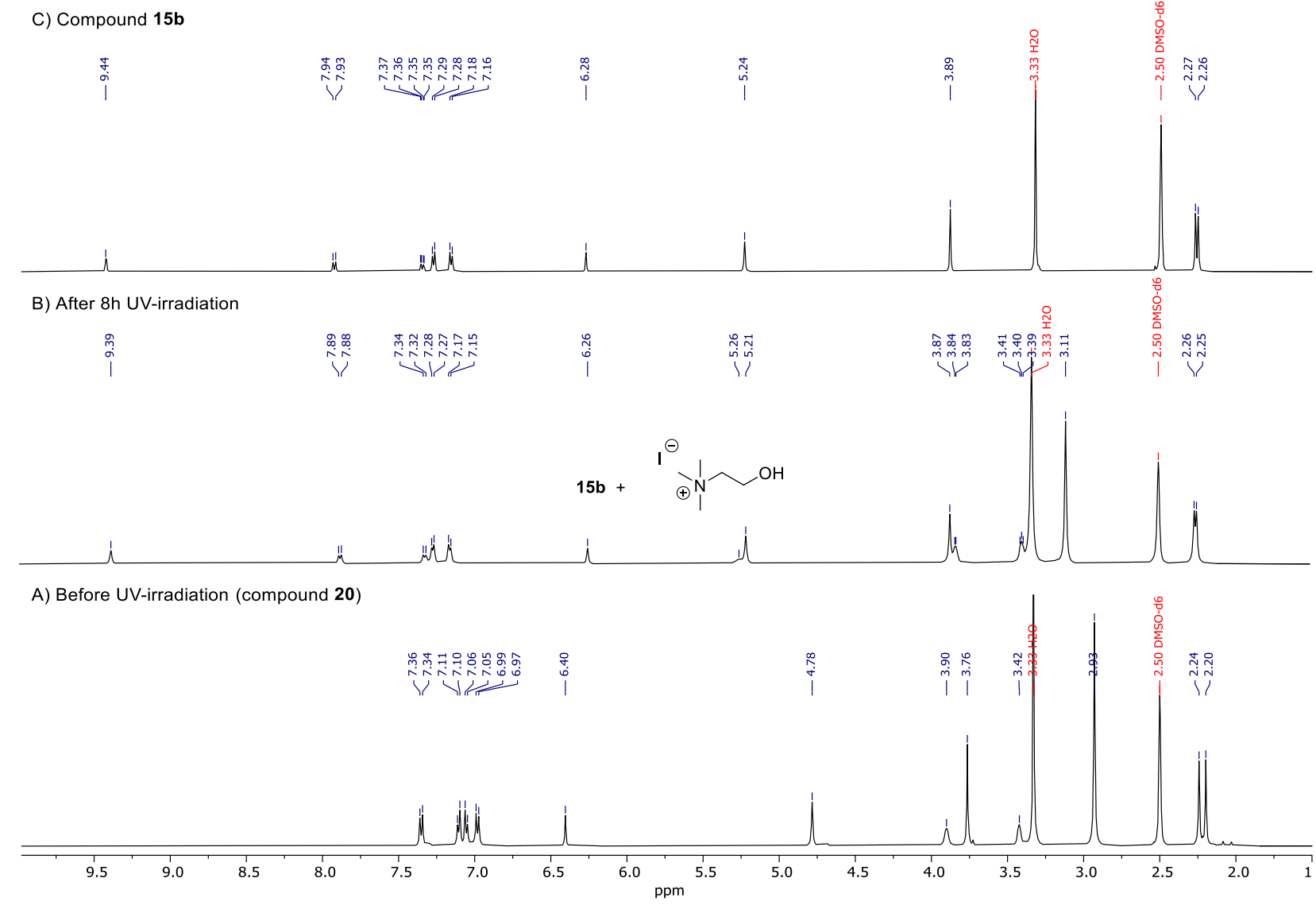

Fig. S6. ${ }^{1} \mathrm{H}$ NMR monitoring of the photoreaction of compound 20 under UV-irradiation $(365 \mathrm{~nm})$ in DMSO- $d_{6}$ solution. 
11. Absorption characteristics of $14 b$ and $15 b$

Table S2. Absorption characteristics of $\mathbf{1 4 b}$ and $\mathbf{1 5 b}$

\begin{tabular}{|c|c|c|}
\hline Compound & $\lambda^{\mathrm{abs}}, \mathrm{nm}$ & $\varepsilon, \mathrm{L} \mathrm{mol}^{-1}, \mathrm{~cm}^{-1}$ \\
\hline \multirow{4}{*}{$14 \mathrm{~b}$} & 270 & 70450 \\
\cline { 2 - 3 } & 310 & 36700 \\
\cline { 2 - 3 } & 340 & 28150 \\
\cline { 2 - 3 } & 380 & 8000 \\
\hline \multirow{4}{*}{$15 \mathrm{~b}$} & 270 & 62100 \\
\cline { 2 - 3 } & 282 & 51150 \\
\cline { 2 - 3 } & 325 & 25250 \\
\cline { 2 - 3 } & 360 & 27500 \\
\hline
\end{tabular}

$\lambda^{\text {abs. }}$ absorption maximum, $\varepsilon$ : molar absorption coefficient 


\section{X-ray crystallographic data and refinement details.}

Crystal structure determination was performed in the Department of Structural Studies of Zelinsky Institute of Organic Chemistry, Moscow. X-ray diffraction data were collected on a Bruker Quest D8 diffractometer equipped with a Photon-III area-detector (shutterless $\varphi$ - and $\omega$-scan technique), using graphite-

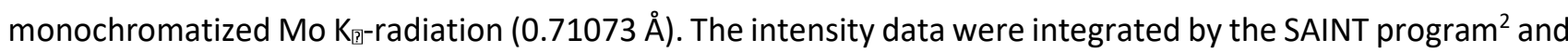
corrected for absorption and decay using $\mathrm{SADABS}^{3}$ (semi-empirically from equivalents). The structure was solved by direct methods using SHELXT ${ }^{4}$ and refined by the full-matrix least-squares method on $F^{2}$ using SHELXL-2018. ${ }^{5}$ All non-hydrogen atoms were refined with anisotropic displacement parameters. All hydrogen atoms were placed in ideal calculated positions ( $\mathrm{C}-\mathrm{H}$ distance $=0.950 \AA$ for aromatic, $0.980 \AA$ for methyl, 0.990 Å for methylene and $1.000 \AA$ for tertiary hydrogen atoms) and refined as riding atoms with relative isotropic displacement parameters taken as $U_{\text {iso }}(\mathrm{H})=1.5 U_{\text {eq }}(\mathrm{C})$ for methyl groups and $U_{\text {iso }}(\mathrm{H})=1.2 U_{\text {eq }}(\mathrm{C})$ otherwise. A rotating group model was applied for methyl groups. The Mercury program ${ }^{6}$ and the SHELXTL program suite ${ }^{2}$ were used for molecular graphics in manuscript and SI, correspondingly. Crystal data, data collection and structure refinement details are summarized in Table S1. 
Table S3. Crystal data and structure refinement

\begin{tabular}{|c|c|}
\hline Identification code & $15 b$ \\
\hline Empirical formula & $\mathrm{C}_{24} \mathrm{H}_{19} \mathrm{~N} \mathrm{O}_{5}$ \\
\hline Formula weight & 401.40 \\
\hline Temperature (K) & $100(2)$ \\
\hline Crystal system & Monoclinic \\
\hline Space group & $\mathrm{P} 21 / \mathrm{n}$ \\
\hline \multicolumn{2}{|l|}{ Unit cell dimensions } \\
\hline$a(\AA)$ & $7.13210(10)$ \\
\hline$b(\AA ̊)$ & $28.3347(5)$ \\
\hline$c(\AA)$ & $9.0500(2)$ \\
\hline$\alpha\left({ }^{\circ}\right)$ & 90 \\
\hline$\beta\left(^{\circ}\right)$ & $90.1110(10)$ \\
\hline$\gamma\left(\left(^{\circ}\right)\right.$ & 90 \\
\hline Volume $\left(\AA^{3}\right)$ & $1828.87(6)$ \\
\hline Z & 4 \\
\hline Density (calculated) $\left(\mathrm{g} / \mathrm{cm}^{3}\right)$ & 1.458 \\
\hline Absorption coefficient $\left(\mathrm{mm}^{-1}\right)$ & 0.103 \\
\hline$F(000)$ & 840 \\
\hline Crystal size (mm) & $0.30 \times 0.10 \times 0.10$ \\
\hline$\theta$ range for data collection $\left({ }^{\circ}\right)$ & 2.362 to 32.048 \\
\hline \multirow[t]{3}{*}{ Index ranges } & $-10<=h<=10$ \\
\hline & $-41<=k<=42$ \\
\hline & $-13<=\mid<=13$ \\
\hline \multicolumn{2}{|l|}{ Reflections } \\
\hline collected & 61745 \\
\hline independent $\left[R_{\text {int }}\right]$ & $6388[0.0668]$ \\
\hline observed $(I>2 \sigma(I))$ & 4791 \\
\hline Completeness to $\theta_{\max }$ & 0.999 \\
\hline Max. / min. transmission & $0.7463 / 0.7073$ \\
\hline Data / restraints / parameters & 6388 / 0 / 274 \\
\hline Goodness-of-fit on $F^{2}$ & 1.034 \\
\hline Final R1 / wR2 indices $(I>2 \sigma(I))$ & $0.0463 / 0.1034$ \\
\hline Final R1 / wR2 indices (all data) & $0.0721 / 0.1188$ \\
\hline Largest diff. peak / hole $\left(e \bullet \AA^{-3}\right)$ & $0.403 /-0.271$ \\
\hline CCDC number & 2080836 \\
\hline
\end{tabular}




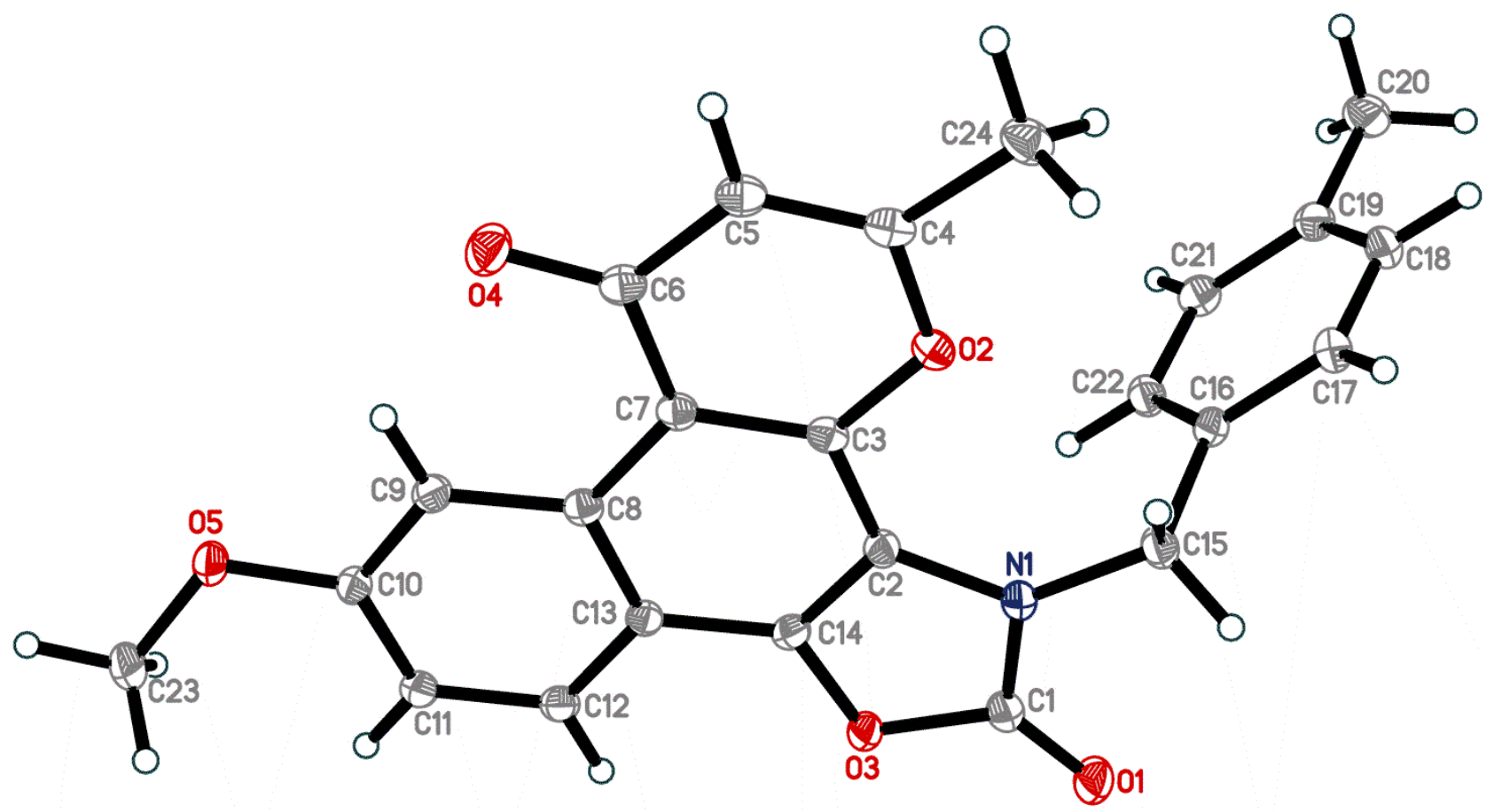

Fig. S7. The structure of $\mathbf{1 5 b}$. Thermal ellipsoids are set to the $50 \%$ probability level. 
Table S4. Selected bond distances in 15b $(\AA ̊)$.

\begin{tabular}{ll|ll|ll}
\hline Bond & Distance & Bond & Distance & Bond & Distance \\
\hline $\mathrm{N}(1)-\mathrm{C}(1)$ & $1.3673(17)$ & $\mathrm{C}(2)-\mathrm{C}(3)$ & $1.4030(17)$ & $\mathrm{C}(12)-\mathrm{C}(13)$ & $1.4072(17)$ \\
$\mathrm{N}(1)-\mathrm{C}(2)$ & $1.4007(15)$ & $\mathrm{C}(3)-\mathrm{C}(7)$ & $1.3933(17)$ & $\mathrm{C}(13)-\mathrm{C}(14)$ & $1.4035(16)$ \\
$\mathrm{N}(1)-\mathrm{C}(15)$ & $1.4560(16)$ & $\mathrm{C}(4)-\mathrm{C}(5)$ & $1.3393(18)$ & $\mathrm{C}(16)-\mathrm{C}(22)$ & $1.3907(17)$ \\
$\mathrm{O}(1)-\mathrm{C}(1)$ & $1.2053(15)$ & $\mathrm{C}(4)-\mathrm{C}(24)$ & $1.4887(18)$ & $\mathrm{C}(16)-\mathrm{C}(17)$ & $1.3945(17)$ \\
$\mathrm{O}(2)-\mathrm{C}(3)$ & $1.3639(14)$ & $\mathrm{C}(5)-\mathrm{C}(6)$ & $1.4518(18)$ & $\mathrm{C}(17)-\mathrm{C}(18)$ & $1.3880(17)$ \\
$\mathrm{O}(2)-\mathrm{C}(4)$ & $1.3663(15)$ & $\mathrm{C}(6)-\mathrm{C}(7)$ & $1.4751(17)$ & $\mathrm{C}(18)-\mathrm{C}(19)$ & $1.3989(18)$ \\
$\mathrm{O}(3)-\mathrm{C}(14)$ & $1.3809(14)$ & $\mathrm{C}(7)-\mathrm{C}(8)$ & $1.4563(17)$ & $\mathrm{C}(19)-\mathrm{C}(21)$ & $1.3908(18)$ \\
$\mathrm{O}(3)-\mathrm{C}(1)$ & $1.3919(15)$ & $\mathrm{C}(8)-\mathrm{C}(9)$ & $1.4148(17)$ & $\mathrm{C}(19)-\mathrm{C}(20)$ & $1.5092(18)$ \\
$\mathrm{O}(4)-\mathrm{C}(6)$ & $1.2360(15)$ & $\mathrm{C}(8)-\mathrm{C}(13)$ & $1.4321(16)$ & $\mathrm{C}(21)-\mathrm{C}(22)$ & $1.3983(17)$ \\
$\mathrm{O}(5)-\mathrm{C}(10)$ & $1.3680(14)$ & $\mathrm{C}(9)-\mathrm{C}(10)$ & $1.3826(17)$ & $\mathrm{C}(16)-\mathrm{C}(17)$ & $1.3945(17)$ \\
$\mathrm{O}(5)-\mathrm{C}(23)$ & $1.4292(16)$ & $\mathrm{C}(10)-\mathrm{C}(11)$ & $1.4109(17)$ & $\mathrm{C}(17)-\mathrm{C}(18)$ & $1.3880(17)$ \\
$\mathrm{C}(2)-\mathrm{C}(14)$ & $1.3554(17)$ & $\mathrm{C}(11)-\mathrm{C}(12)$ & $1.3716(17)$ & $\mathrm{C}(18)-\mathrm{C}(19)$ & $1.3989(18)$ \\
\hline
\end{tabular}

Table S5. Selected bond angle values in $\mathbf{1 5 b}\left({ }^{\circ}\right)$.

\begin{tabular}{ll|ll}
\hline Bond angle & Value & Bond angle & Value \\
\hline$C(1)-N(1)-C(2)$ & $108.54(10)$ & $O(4)-C(6)-C(7)$ & $124.52(12)$ \\
$C(1)-N(1)-C(15)$ & $121.98(10)$ & $C(5)-C(6)-C(7)$ & $114.86(11)$ \\
$C(2)-N(1)-C(15)$ & $129.45(10)$ & $C(3)-C(7)-C(8)$ & $119.08(11)$ \\
$C(3)-O(2)-C(4)$ & $119.01(10)$ & $C(3)-C(7)-C(6)$ & $116.98(11)$ \\
$C(14)-O(3)-C(1)$ & $106.99(9)$ & $C(8)-C(7)-C(6)$ & $123.93(11)$ \\
$C(10)-O(5)-C(23)$ & $117.36(10)$ & $C(9)-C(8)-C(13)$ & $117.01(11)$ \\
$O(1)-C(1)-N(1)$ & $129.48(12)$ & $C(9)-C(8)-C(7)$ & $123.01(11)$ \\
$O(1)-C(1)-O(3)$ & $122.69(12)$ & $C(13)-C(8)-C(7)$ & $119.98(11)$ \\
$N(1)-C(1)-O(3)$ & $107.82(10)$ & $C(10)-C(9)-C(8)$ & $120.66(11)$ \\
$C(14)-C(2)-N(1)$ & $106.87(10)$ & $O(5)-C(10)-C(9)$ & $115.54(11)$ \\
$C(14)-C(2)-C(3)$ & $119.74(11)$ & $O(5)-C(10)-C(11)$ & $122.57(11)$ \\
$N(1)-C(2)-C(3)$ & $133.34(11)$ & $C(9)-C(10)-C(11)$ & $121.89(11)$ \\
$O(2)-C(3)-C(7)$ & $124.64(11)$ & $C(12)-C(11)-C(10)$ & $118.52(11)$ \\
$O(2)-C(3)-C(2)$ & $114.99(10)$ & $C(11)-C(12)-C(13)$ & $121.07(11)$ \\
$C(7)-C(3)-C(2)$ & $120.37(11)$ & $C(14)-C(13)-C(12)$ & $122.93(11)$ \\
$C(5)-C(4)-O(2)$ & $121.04(11)$ & $C(14)-C(13)-C(8)$ & $116.22(11)$ \\
$C(5)-C(4)-C(24)$ & $128.13(12)$ & $C(12)-C(13)-C(8)$ & $120.84(11)$ \\
$O(2)-C(4)-C(24)$ & $110.83(11)$ & $C(2)-C(14)-O(3)$ & $109.78(10)$ \\
$C(4)-C(5)-C(6)$ & $123.45(12)$ & $C(2)-C(14)-C(13)$ & $124.61(11)$ \\
$O(4)-C(6)-C(5)$ & $120.62(12)$ & $O(3)-C(14)-C(13)$ & $125.58(11)$ \\
$O(4)-C(6)-C(7)$ & $124.52(12)$ & $N(1)-C(15)-C(16)$ & $114.14(10)$ \\
$C(5)-C(6)-C(7)$ & $114.86(11)$ & $C(22)-C(16)-C(17)$ & $118.88(11)$ \\
$C(3)-C(7)-C(8)$ & $119.08(11)$ & $C(22)-C(16)-C(15)$ & $123.10(11)$ \\
$C(3)-C(7)-C(6)$ & $116.98(11)$ & $C(17)-C(16)-C(15)$ & $117.99(11)$ \\
& & &
\end{tabular}




\begin{tabular}{ll|ll}
$C(8)-C(7)-C(6)$ & $123.93(11)$ & $C(18)-C(17)-C(16)$ & $120.72(12)$ \\
$C(9)-C(8)-C(13)$ & $117.01(11)$ & $C(17)-C(18)-C(19)$ & $120.86(12)$ \\
$C(9)-C(8)-C(7)$ & $123.01(11)$ & $C(21)-C(19)-C(18)$ & $118.16(11)$ \\
$C(13)-C(8)-C(7)$ & $119.98(11)$ & $C(21)-C(19)-C(20)$ & $121.98(12)$ \\
$C(10)-C(9)-C(8)$ & $120.66(11)$ & $C(18)-C(19)-C(20)$ & $119.84(12)$ \\
$O(4)-C(6)-C(5)$ & $120.62(12)$ & $C(19)-C(21)-C(22)$ & $121.18(12)$ \\
& & $C(16)-C(22)-C(21)$ & $120.20(12)$ \\
\hline
\end{tabular}

Table S6. Selected torsion angles in $\mathbf{1 5 b}\left({ }^{\circ}\right)$.

\begin{tabular}{|c|c|c|c|}
\hline Torsion angle & Value & Torsion angle & Value \\
\hline$C(2)-N(1)-C(1)-O(1)$ & $178.54(13)$ & $C(7)-C(8)-C(9)-C(10)$ & $-178.95(11)$ \\
\hline$C(15)-N(1)-C(1)-O(1)$ & $0.3(2)$ & $C(23)-O(5)-C(10)-C(9)$ & $-170.12(11)$ \\
\hline$C(2)-N(1)-C(1)-O(3)$ & $-0.36(13)$ & $C(23)-O(5)-C(10)-C(11)$ & $10.49(17)$ \\
\hline$C(15)-N(1)-C(1)-O(3)$ & $-178.58(10)$ & $C(8)-C(9)-C(10)-O(5)$ & $179.19(10)$ \\
\hline$C(14)-O(3)-C(1)-O(1)$ & $-178.75(12)$ & $C(8)-C(9)-C(10)-C(11)$ & $-1.41(18)$ \\
\hline $\mathrm{C}(14)-\mathrm{O}(3)-\mathrm{C}(1)-\mathrm{N}(1)$ & $0.24(13)$ & $O(5)-C(10)-C(11)-C(12)$ & $-179.34(11)$ \\
\hline$C(1)-N(1)-C(2)-C(14)$ & $0.35(13)$ & $C(11)-C(12)-C(13)-C(8)$ & $-0.74(17)$ \\
\hline$C(15)-N(1)-C(2)-C(14)$ & $178.38(11)$ & $C(9)-C(8)-C(13)-C(14)$ & $-178.57(10)$ \\
\hline$C(1)-N(1)-C(2)-C(3)$ & $177.74(13)$ & $C(7)-C(8)-C(13)-C(14)$ & $0.81(16)$ \\
\hline$C(15)-N(1)-C(2)-C(3)$ & $-4.2(2)$ & $C(9)-C(8)-C(13)-C(12)$ & $0.64(16)$ \\
\hline$C(4)-O(2)-C(3)-C(7)$ & $0.55(17)$ & $C(7)-C(8)-C(13)-C(12)$ & $-179.97(10)$ \\
\hline$C(4)-O(2)-C(3)-C(2)$ & $-179.41(10)$ & $N(1)-C(2)-C(14)-O(3)$ & $-0.19(13)$ \\
\hline$C(14)-C(2)-C(3)-O(2)$ & $-179.44(10)$ & $C(3)-C(2)-C(14)-O(3)$ & $-178.01(10)$ \\
\hline$N(1)-C(2)-C(3)-O(2)$ & $3.43(19)$ & $N(1)-C(2)-C(14)-C(13)$ & $177.90(11)$ \\
\hline$C(14)-C(2)-C(3)-C(7)$ & $0.60(17)$ & $C(3)-C(2)-C(14)-C(13)$ & $0.08(18)$ \\
\hline$N(1)-C(2)-C(3)-C(7)$ & $-176.53(12)$ & $C(1)-O(3)-C(14)-C(2)$ & $-0.03(13)$ \\
\hline$C(3)-O(2)-C(4)-C(5)$ & $0.77(16)$ & $C(1)-O(3)-C(14)-C(13)$ & $-178.10(11)$ \\
\hline$C(3)-O(2)-C(4)-C(24)$ & $-179.32(10)$ & $C(12)-C(13)-C(14)-C(2)$ & $-179.98(11)$ \\
\hline$O(2)-C(4)-C(5)-C(6)$ & $-1.43(19)$ & $C(8)-C(13)-C(14)-C(2)$ & $-0.78(17)$ \\
\hline$C(24)-C(4)-C(5)-C(6)$ & $178.67(12)$ & $C(12)-C(13)-C(14)-O(3)$ & $-2.18(18)$ \\
\hline$C(4)-C(5)-C(6)-O(4)$ & $-179.36(12)$ & $C(8)-C(13)-C(14)-O(3)$ & $177.02(10)$ \\
\hline$C(4)-C(5)-C(6)-C(7)$ & $0.76(18)$ & $C(1)-N(1)-C(15)-C(16)$ & $94.93(14)$ \\
\hline$C(1)-N(1)-C(2)-C(3)$ & $177.74(13)$ & $C(2)-N(1)-C(15)-C(16)$ & $-82.87(15)$ \\
\hline$O(2)-C(3)-C(7)-C(8)$ & $179.52(10)$ & $N(1)-C(15)-C(16)-C(22)$ & $-13.27(17)$ \\
\hline$C(2)-C(3)-C(7)-C(8)$ & $-0.52(16)$ & $N(1)-C(15)-C(16)-C(17)$ & $168.77(11)$ \\
\hline$O(2)-C(3)-C(7)-C(6)$ & $-1.14(17)$ & $C(22)-C(16)-C(17)-C(18)$ & $-0.25(19)$ \\
\hline
\end{tabular}




\begin{tabular}{lr|rr}
$C(2)-C(3)-C(7)-C(6)$ & $178.81(10)$ & $C(15)-C(16)-C(17)-C(18)$ & $177.79(11)$ \\
$O(4)-C(6)-C(7)-C(3)$ & $-179.40(12)$ & $C(16)-C(17)-C(18)-C(19)$ & $0.3(2)$ \\
$C(5)-C(6)-C(7)-C(3)$ & $0.48(15)$ & $C(17)-C(18)-C(19)-C(21)$ & $-0.29(19)$ \\
$O(4)-C(6)-C(7)-C(8)$ & $-0.10(19)$ & $C(17)-C(18)-C(19)-C(20)$ & $178.47(12)$ \\
$C(5)-C(6)-C(7)-C(8)$ & $179.78(10)$ & $C(18)-C(19)-C(21)-C(22)$ & $0.21(19)$ \\
$C(3)-C(7)-C(8)-C(9)$ & $179.15(11)$ & $C(20)-C(19)-C(21)-C(22)$ & $-178.52(12)$ \\
$C(6)-C(7)-C(8)-C(9)$ & $-0.14(18)$ & $C(17)-C(16)-C(22)-C(21)$ & $0.18(19)$ \\
$C(3)-C(7)-C(8)-C(13)$ & $-0.20(16)$ & $C(15)-C(16)-C(22)-C(21)$ & $-177.76(12)$ \\
$C(6)-C(7)-C(8)-C(13)$ & $-179.49(11)$ & $C(19)-C(21)-C(22)-C(16)$ & $-0.16(19)$ \\
$C(13)-C(8)-C(9)-C(10)$ & $0.42(16)$ & & \\
\hline
\end{tabular}

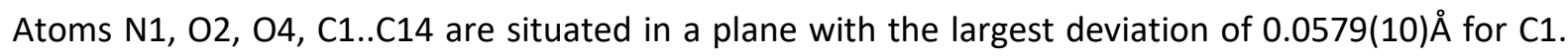
Atoms $01,03,05, \mathrm{C} 15, \mathrm{C} 24$ are also located in the same plane with the largest deviation of 0.0799(13)Å for 01, whereas atom C23 does not lie in the plane and deviates by $0.3104(17) \AA$. The dihedral angle between the planes defined by atoms $\mathrm{N} 1, \mathrm{O} 2, \mathrm{O} 4, \mathrm{C} 1 . . \mathrm{C} 14$ and by atoms $\mathrm{C} 16 . . \mathrm{C} 22$ of the phenyl ring is $87.914(20)^{\circ}$. 


\section{References}

1. Komogortsev, A. N.; Melekhina, V. G.; Lichitsky, B. V. The synthesis of novel type of $a$-aminoketones containing allomaltol fragment. Synth. Commun. 2021, 51, 5, 701-708

2. Bruker. APEX-III. Bruker AXS Inc., Madison, Wisconsin, USA, 2019.

3. Krause, L.; Herbst-Irmer, R.; Sheldrick, G. M.; Stalke, D. Comparison of silver and molybdenum microfocus X-ray sources for single-crystal structure determination. J. Appl. Cryst. 2015, 48, 1, 3-10.

4. Sheldrick, G.M. SHELXT - Integrated space-group and crystal-structure determination. Acta Cryst. 2015, A71, 1, 3-8.

5. Sheldrick, G.M. Crystal structure refinement with SHELXL. Acta Cryst. 2015, C71, 1, 3-8.

6. Macrae, C.F.; Sovago, I.; Cottrell, S.J.; Galek, P.T.A.; McCabe, P.; Pidcock, E.; Platings, M.; Shields, G. P.; Stevens, J.S.; Towler, M.; Wood, P.A. Mercury 4.0: from visualization to analysis, design and prediction, J. Appl. Cryst. 2020, 53, 1, 226-235. 